\title{
FORMAÇÃO DOCENTE E RACIONALIDADE INSTRUMENTAL: reflexões sobre a Psicologia a partir do depoimento de professores
}

ALINE FROLLINI LUNARDELLI LARA

BANCA EXAMINADORA

(Nome e Assinatura)

(Nome e Assinatura)

(Nome e Assinatura)

Dissertação defendida e aprovada em 
AUTORIZO A REPRODUÇÃO E DIVULGAÇÃO TOTAL OU PARCIAL DESTE TRABALHO, POR QUALQUER MEIO CONVENCIONAL OU ELETRÔNICO, PARA FINS DE ESTUDO E PESQUISA, DESDE QUE CITADA A FONTE.

Catalogação na publicação

Serviço de Biblioteca e Documentação

Instituto de Psicologia da Universidade de São Paulo

Lara, Aline Frollini Lunardelli.

Formação docente e racionalidade instrumental: reflexões sobre a psicologia a partir do depoimento de professores / Aline Frollini Lunardelli Lara; orientadora Maria Helena Souza Patto. -- São Paulo, 2006.

205 p.

Dissertação (Mestrado - Programa de Pós-Graduação em Psicologia. Área de Concentração: Psicologia Escolar e do Desenvolvimento Humano) - Instituto de Psicologia da Universidade de São Paulo.

1. Formação de professores 2. Psicologia I. Título.

BF1715 


\section{DEDICATÓRIA}

À minha mãe, pela vida compartilhada, pelo amor, companheirismo e amizade. Por toda sua competência intelectual, ética e política em sua atuação como professora e psicóloga. 


\section{AGRADECIMENTOS}

Ao meu marido Rodrigo, por ter sido namorado, noivo, companheiro e desde sempre ter acreditado em meus sonhos. Por dividir sonhos. Por todo o amor.

À minha mãe Maria Cristina, por tantas idéias compartilhadas, pelo exemplo de vida, por sua trajetória acadêmica, por ter me dado meus primeiros livros.

Ao meu pai Amadeu, que sem entender nada de Psicologia, passou a compreender a importância dela na vida da sua filha "guerrilheira”.

À minha orientadora Maria Helena Souza Patto, por ter desconstruído concepções antes inabaladas e por ter me ajudado a construir outra identidade profissional. Pelo respeito e cuidado com a minha formação e pelos valiosos ensinamentos que, a cada orientação, me tornaram uma pessoa diferente.

A Michelle Franco Redondo, por compartilhar a intransigência, a indignação e a esperança que nos movem nessa vida.

A Elaine Luiza Bressan Guidotti, por todos os incentivos, por acreditar em mim, por compartilhar a vida na Psicologia e fora dela.

A Juliana Campregher Pasqualini, pelo futuro que juntas vislumbramos.

A Janyssa Oliveria Szanto, por me ouvir a cada retorno das entrevistas e me ajudar nessa difícil caminhada.

A Elenita de Ricio Tanamachi, com quem entendi a importância da Psicologia e da Educação. Obrigada por ainda caminhar comigo.

Aos amigos Sylvia Nunes, Juliana Lopes e Arnaldo Cheixas, por me acolherem na USP e dividirem almoços que poderiam ter sido tão solitários.

Ao professor Ari Fernando Maia, que assistiu aos meus primeiros ensaios na Psicologia e esteve presente ao longo dessa minha jornada, mesmo que não soubesse de sua importância na construção de meus pensamentos.

Ao professor José Leon Crochik, por suas importantes contribuições para este trabalho e para a minha formação.

Aos professores Nancy, Wanda, Márcia, Carla, Antônio Carlos, Maristela e Sandra que me concederam tão gentilmente seus depoimentos, pelo tempo dispensado, 
por ter contribuído de maneira tão significativa para que eu compreendesse o lugar da Psicologia na Educação, mesmo que ainda não saibam disso.

Ao CNPq, pelo financiamento que viabilizou o desenvolvimento desta pesquisa. 


\section{SUMÁRIO}

Resumo

Abstract

CAPÍTULO I - A PSICOLOGIA NO CONTEXTO DA FORMAÇÃO DE PROFESSORES

1.1 A ideologia das aptidões naturais

1.2 A Escola Nova e a psicologia

1.3 A psicologia na pesquisa sobre a formação de educadores

\section{CAPÍTULO II - A PESQUISA}

2.1 Escolha do local de pesquisa

2.2. Escolha dos participantes da pesquisa

2.2.1 Contato inicial com os docentes

2.2.2 Escolha dos participantes da etapa de entrevistas

2.3. As entrevistas

2.3.1 Conversa inicial não gravada

2.3.2 Entrevista gravada semi-dirigida sobre a formação profissional do docente

2.3.3 Discussão do depoimento com o entrevistado

2.4. Análise das entrevistas

CAPÍTULO III - OS DEPOENTES

CAPÍTULO IV - A RELAÇÃO COM A PSICOLOGIA: o pedido de socorro

CAPÍTULO V - O CAMINHO PERCORRIDO: da formação profissional à experiência de vida 
CAPÍTULO VI - A RELAÇÃO TEORIA-PRÁTICA: busca de eficiência pedagógica

CAPÍTULO VII - O CENÁRIO DA IMPOTÊNCIA: como vivem os professores na escola

CAPÍTULO VIII - A FORMAÇÃO DOS FORMADORES: predomínio da razão instrumental nos processos de pseudoformação

8.1 A política neoliberal para a educação

8.2 Do coletivo ao individual - a psicologização da escola

8.3 A finalidade da educação e a formação dos formadores

8.4 O predomínio da racionalidade instrumental na formação

8.5 O retorno à teoria como resgate da liberdade

8.6 De que vale a teoria? - a construção de experiências intelectuais

8.7 O abandono da teoria e o processo de pseudoformação

8.8 Da psicologia dos depoimentos a uma outra psicologia: a desconstrução

REFERÊNCIAS BIBLIOGRÁFICAS 


\section{RESUMO}

LARA, Aline Frollini Lunardelli. Formação docente e racionalidade instrumental: reflexões sobre a Psicologia a partir do depoimento de professores. São Paulo, 2006. 205 p. Dissertação (Mestrado). Instituto de Psicologia, Universidade de São Paulo.

O tema formação de professores tem sido foco de inúmeras pesquisas e trabalhos publicados nas áreas da Educação e da Psicologia. Dos vários elementos que compõem a formação do educador, um se refere à obrigatoriedade da disciplina Psicologia da Educação no currículo dos cursos de magistério, licenciatura ou Pedagogia. Os estudos sobre o tema, geralmente, tratam da análise da estrutura dos currículos e de novas estratégias para o ensino dessa ciência. Entretanto, a compreensão da maneira como a Psicologia se configura na formação docente, a partir da reflexão do educador, ainda não se constituiu como uma linha de pesquisa. Neste contexto, este estudo teve por objetivo investigar como a Psicologia está presente na formação e no trabalho pedagógico de professores a partir de sua própria análise. Buscou, especificamente, compreender a apropriação e a avaliação do professor do que lhe foi ensinado sobre Psicologia ao longo de sua formação e suas expectativas com relação a este saber. Para tanto, sete professores de uma escola municipal pública de ensino fundamental I e da educação de jovens e adultos da cidade de São Paulo foram entrevistados. A coleta de depoimentos foi feita em três fases: conversa inicial não gravada, entrevista gravada semi-dirigida sobre a biografia profissional do docente e discussão gravada do depoimento com o entrevistado. A leitura das entrevistas levou à constituição de quatro categorias de análise: 1. A relação do depoente com a Psicologia; 2. Como ela se apresenta em sua formação; 3. A realidade da escola pública atual; e 4. A relação entre teoria e prática. Esta última tornou-se o eixo de discussão sobre a formação docente em Psicologia, uma vez que perpassa todas as outras categorias. Verificou-se que os professores aprenderam uma psicologia que fundamenta a expectativa do ensino individualizado, com base na relação dual professor-aluno, e que, na formação do educador, ela configura-se como instrumento técnico-prático de eficiência pedagógica. A teoria, nesse sentido, é entendida como razão instrumental, pragmática e utilitarista. As reflexões deste estudo apontam para a necessidade de se discutir a construção de um outro espaço para a Psicologia na formação docente, que rompa com o modelo essencialmente tecnicista.

Palavras-chave: Formação de professores; Psicologia; Relação teoria x prática. 


\begin{abstract}
LARA, Aline Frollini Lunardelli. Teacher Education and Instrumental Rationality: Reflections about the Psychology from the statement of teachers. São Paulo, 2006. 205p. Dissertation (Master’s degree). Institute of Psychology, University of São Paulo.

The theme teacher education has been the focus of uncounted researches and essays published in the areas of Education and Psychology. From the various elements that compose the education of the educator, one is related to the obligatoriness of the subject Psychology of Education in the curriculum of the mastership courses, graduation or Pedagogy. Generally, the studies about the theme talk about the structure of the curriculum and the new teaching strategies of this science. However, the comprehension about the way the psychology is configured in teacher education, based on the educator reflection, has not been constituted as a research line yet. In this context, this study had as primary aim, investigate how the Psychology is present in the teachers' education and pedagogical work, based on their own analysis. It seek, specifically, understand the teacher's appropriation and the evaluation of what was taught to them about Psychology during their education, and their expectancies in relation to this knowledge. For this, seven teachers from a municipal public school of elementary and adult and youth education in the city of São Paulo were interviewed. The data collection was developed in three phases: an initial non-recorded talk, a recorded semi-structured interview about the teacher's professional biography, and recorded discussion of the interviewed statement. The reading of the interviews led to the constitution of four categories of analysis: 1 . The relation between the deponent and the Psychology; 2. How it is presented in his/her education; 3. The actual reality of the public school; and 4. The relation between theory and practical. The last one became the pivot of discussion about the teacher education in Psychology, once it goes through all the other categories. It was verified that the teachers learnt a kind of Psychology that justify the expectancy of individualized teaching, having as basis the dual relation between teacher-student, and that, in the teacher education, it is configured as a technical-practical instrument of pedagogical efficiency. The theory, in this meaning, is understood as instrumental reason, pragmatic and utilitarian. The reflections of this study indicate the necessity of discussing the construction of another space to the Psychology in the teacher education that disrupt with the technicist model primarily.
\end{abstract}

Key words: Teacher education; Psychology; Relation between theory x practical. 


\section{CAPÍTULO I - A PSICOLOGIA NO CONTEXTO DA FORMAÇÃO DE PROFESSORES}

Existem atualmente, no Brasil, 2138 cursos de formação de professores, divididos em 765 Cursos Normais Superiores (que surgiram em 1999) e 1373 cursos de Pedagogia. Do total, 38,54\% estão vinculados a instituições públicas federais e estaduais e $61,31 \%$, a instituições privadas ${ }^{1}$. Estes são alguns dos resultados de um estudo feito por Campos (2004) sobre os impactos da reforma na formação de professores da educação básica no Brasil. A pesquisa ocupou-se dos cursos de formação para a docência na educação infantil e nas séries iniciais do ensino fundamental e buscou compreender como eles estão organizados, nos seguintes aspectos: a) a expansão quantitativa dos cursos em nível nacional, b) a diversificação das instituições, c) o tipo de formação almejada e d) o formato dos cursos (modalidade de freqüência, turno de oferta, carga horária e número de vagas).

De acordo com a autora, a necessidade de se investigar o cenário da formação de professores no país, analisando os impactos da reforma feita pelo Ministério da Educação na década de 90, se dá a partir do momento em que:

A crise educacional então, objeto de discursos pronunciados por atores sociais diversos, foi, predominantemente, traduzida como uma crise de eficiência, eficácia e produtividade do sistema, sugerindo-se para a sua superação a adoção de mecanismos corretivos baseados no mercado: a educação deixa de ser compreendida como direito para ser tratada como oportunidade (CAMPOS, 2004, p. 2).

A crise no sistema educacional justificaria, dessa forma, o investimento na formação de professores que ora são vistos como culpados pelo fracasso da escola, ora como salvadores. A reforma no sistema de formação docente, segundo a autora, teve como conseqüência o aprofundamento de uma concepção técnico-instrumental de

\footnotetext{
${ }^{1}$ A diferença é compreensível: os cursos de Pedagogia são de instalação barata, em comparação com cursos que exigem instalações de alto custo, como os cursos de Medicina, por exemplo.
} 
formação ${ }^{2}$, o que resultou, por exemplo, na quantidade de cursos de formação com menos de 3000 horas de duração existentes no país, gerando prejuízo à qualidade do ensino, bem como o número de cursos à distância, já em funcionamento, autorizados pelo Ministério da Educação. Para Campos, os cursos à distância eram cerca de oito em 1998, passando para quarenta e sete em 2002. Neles, há, atualmente, em torno de 39.000 alunos matriculados. A autora conclui que a expansão acelerada dos cursos de formação de professores, principalmente nas instituições privadas:

\begin{abstract}
Tornou-se um verdadeiro "empório" com produtos variados, dependendo da demanda do cliente. A ascensão da formação de professores como um mercado atraente deu-se associada a um outro movimento: a retirada da formação do interior dos cursos de pedagogia, em especial nas instituições privadas. Esvaziadas de sua principal função, as instituições privadas passaram a conviver com problemas tais como a baixa procura por esses cursos, a inadimplência, a evasão, para citar alguns. Esse contexto engendrou um movimento de ressignificação das funções dos cursos destinados então, a formar os pedagogos. Na construção de novos discursos que os tornassem atraentes e, sobretudo, apoiados no discurso midiático do "novo", vimos os cursos de pedagogia transfigurarem-se em mercadorias ${ }^{3}$, cujos rótulos encerram promessas de empregabilidade em outros segmentos do mercado de trabalho, descaracterizando o espaço da educação como a finalidade da formação de seus profissionais (Id. Ibid., p. 40-41).
\end{abstract}

Neste mesmo contexto, a Associação Nacional pela Formação dos Profissionais da Educação (ANFOPE) vem, desde seu primeiro congresso em 1983, discutindo as políticas públicas de formação de professores no país. O movimento já produziu uma série de documentos, discussões e exigências aos órgãos oficiais de ensino, contrários às propostas que tornam a formação de educadores mais uma mercadoria. Criticam o posicionamento do Ministério da Educação no que se refere à propagação de cursos sem as condições necessárias para uma formação de qualidade:

\footnotetext{
${ }^{2}$ É importante ressaltar que a crise da educação descrita pela autora, com sua conseqüente mercantilização e aprofundamento da concepção técnico-instrumental, não provém, inicialmente, do mercado, mas da racionalidade da produção industrial que se generaliza para todos os processos sociais.

${ }^{3}$ O que já havia ocorrido muito antes desse período. Trata-se, portanto, de um aperfeiçoamento de reformas educacionais anteriores.
} 
A ênfase no treinamento em serviço, utilizando-se, em várias oportunidades, da modalidade de Educação à distância, implementada não como um complemento aos processos de formação, mas como substituto dos modelos presenciais, em grande parte alimenta políticas clientelistas e corporativas de alguns setores e como forma de aligeirar e baratear a formação inicial e continuada (ANFOPE, 2004, p. 9).

A ANFOPE tem defendido a formação dos profissionais da educação com duração mínima de quatro anos e de 3200 horas, criticando severamente os cursos à distância. Propõe como eixos norteadores da educação de professores a sólida formação teórica e interdisciplinar, a unidade entre teoria e prática, a aproximação entre a licenciatura e o bacharelado, a gestão democrática da escola, o compromisso social e ético do profissional da educação, o trabalho coletivo e interdisciplinar e a articulação da formação inicial e continuada:

A formação de professores é um desafio que tem a ver com o futuro da educação básica, esta por sua vez, intimamente vinculada com o futuro de nosso povo e a formação de nossas crianças, jovens e adultos. No entanto, as perspectivas de que essa formação se faça em bases teoricamente sólidas e fundada nos princípios de uma formação de qualidade e relevância social são cada vez mais remotas, se não conseguirmos reverter o rumo das políticas educacionais implementadas [...]. A redução dos recursos públicos para a educação pública, o processo de asfixia a que as Universidades públicas estão sendo sujeitas, a trágica realidade da escola pública [...] vão evidenciando a impossibilidade de resolução desses problemas nos marcos das relações sociais vigentes. A consciência dessa situação por parte dos educadores exige o desvelamento dos reais fundamentos das propostas de formação de professores em curso em nosso país. Assumir com radicalidade as propostas de profissionalização do magistério, dando-lhes o conteúdo que o movimento dos educadores vem construindo ao longo de sua história, parece ser o desafio atual (ANFOPE, 2000, p. 8, apud ANFOPE, 2004, p. 14).

Para a ANFOPE, a discussão sobre formação de professores não envolve apenas áreas específicas do conhecimento, nem tampouco conteúdos particulares das disciplinas que compõem o currículo dos cursos formadores. Trata-se de uma reivindicação mais ampla junto aos órgãos oficiais, incluindo principalmente o Ministério da Educação, de construção de políticas para a formação de educadores e não apenas para a autorização de funcionamento de cursos que objetivam tão somente o lucro. 
Assim, a discussão sobre os rumos da formação de professores no país, além de envolver níveis mais altos da hierarquia, abrange ações que podem ser desenvolvidas em cada curso em particular ou ainda reflexões e estudos sobre aspectos fundamentais da formação, como a necessidade de se articular o conteúdo específico de cada área de formação com as disciplinas pedagógicas dos currículos, aspecto ressaltado pela ANFOPE.

Em seu discurso, com intenções críticas e progressistas, a ANFOPE reproduz, todavia, um objetivo essencial dos cursos de formação: o aperfeiçoamento das relações ensino-aprendizagem por meio da transmissão de melhores recursos técnicos aos futuros docentes.

Nos cursos Normal Superior, de Pedagogia e nas licenciaturas destaca-se a presença obrigatória da psicologia, como parte do rol das disciplinas pedagógicas. Sua inserção nos meios educacionais e sua obrigatoriedade nos cursos de formação de professores não se deu ao acaso. Entender como a psicologia tornou-se parte integrante dos currículos dos cursos de formação é tarefa fundamental para compreender sua configuração atual na preparação docente.

\subsection{A ideologia das aptidões naturais}

De acordo com Bisseret (1979), a psicologia, a partir do final do século XIX, juntamente com outras áreas do conhecimento, servirá para dar legitimidade científica à ideologia das aptidões naturais.

Em seu surgimento, no século XV, o termo aptidão possuía como significado a habilidade para exercer uma profissão, receber um legado; tendência natural para alguma coisa, na qual a idéia de natureza estava relacionada à vontade divina. O poder de um indivíduo, portanto, era determinado por seu nascimento e não por suas aptidões (Id. Ibid.).

A partir do século XVII, o termo aptidão se articula às noções de mérito e de responsabilidade individual, como parte da ideologia burguesa, juntamente com o 
princípio de igualdade e de competência. Ele passa a explicar as desigualdades escolares e sociais:

Após a Revolução Francesa, se o seu lugar [da aptidão] permanece central nesse sistema ideológico, a função que ela exerce se altera radicalmente: a noção de aptidão, a partir daí, serve progressivamente de suporte para justificar a manutenção das desigualdades sociais e das desigualdades escolares que as traduzem e perpetuam (Id. Ibid., p. $31)$.

Nos princípios que compuseram a ideologia burguesia, as condições sociais e escolares eram dadas como igualitárias para todos os indivíduos, por conseguinte, a aptidão passa a explicar as desigualdades, por ser um dado natural.

O conceito de aptidão apóia-se na ciência, segundo Bisseret (1979), a partir do século XIX com o auxílio da antropometria, da biologia e das ciências humanas. Aptidão, dessa forma, torna-se característica essencial e hereditária.

A psicologia diferencial toma a noção de aptidão do senso comum e lhe dá caráter científico, passando a explicar relações de desigualdade econômica, social e política por meio deste conceito. O caráter hereditário das aptidões determina o lugar social dos indivíduos.

As mudanças sociais, políticas e econômicas, portanto, produzem mudanças no conceito de aptidão. Para ter poder político, a burguesia une-se ao povo com os princípios de liberdade, igualdade e fraternidade que não podem ser mantidos para que se estabeleça seu poder. A aptidão, assim, vem para explicar a falta de igualdade e de poder entre os homens:

[...] Essa confrontação, na verdade, lhe é muito mais crucial, na medida em que ela [a burguesia] não pode recusar o princípio da igualdade, em cujo nome reivindicou seus direitos face à nobreza. Por isso, não cessa de afirmar: sendo todos livres e iguais no direito, o destino do ser humano não depende mais da ordem estabelecida, mas das capacidades individuais. Vai, dessa forma, se consolidar como classe negando àqueles que ela submete ao seu poder político e econômico as qualidades essenciais de inteligência, mérito e responsabilidade, que atribui a si própria e que justificam sua dominação (BISSERET, 1979, p. 40). 
A partir da segunda metade do século XIX, de acordo com a autora, a aptidão depende da causalidade estritamente biológica. As desigualdades sociais estão sujeitas, assim, à natureza biológica: irredutível e determinante:

[...] As conotações do termo aptidão tornaram-se então progressivamente as de um dado imutável, permanente, hereditário, que determina o destino de um indivíduo: a aptidão perdeu o sentido de característica aleatória que, no século XVIII, lhe conferia a idéia de liberdade humana e, antes do século XVIII, a idéia de liberdade divina (Id. Ibid., p. 41).

Nesse período, destaca-se a importância dos trabalhos de Darwin sobre a seleção natural e a sobrevivência dos mais aptos. Com os estudos de Gobineau e a teoria evolucionista, a dominação torna-se natural, inevitável e legítima. Dessa forma, as dimensões psíquicas e sociais são determinadas pela dimensão biológica.

A que vem a psicologia nesse contexto?

Como o trabalho social divide-se cada vez mais em tarefas múltiplas e hierarquizadas, exige-se a formação técnica e especializada dos indivíduos. A psicologia atua, assim, na seleção profissional: cada um trabalharia de acordo com suas aptidões.

Surgem os testes psicológicos: a ciência das aptidões garante a legitimidade da ordem social: “[...] esta ciência deveria permitir detectar as 'verdadeiras’ aptidões escondidas, segundo as quais cada um teria atribuído seu lugar na sociedade” (BISSERET, 1979, p. 46).

Com os testes psicológicos de Binet, passa-se a explicar que o nível intelectual se modifica de acordo com a riqueza material. Os seus trabalhos fixam idades de início e término da escolaridade e o desempenho exigido para cada idade, idéia que, com poucas variações, permanece até os dias atuais. A psicologia dos testes se constitui com base nas ciências naturais, de acordo com o modelo positivista, que lhe dá status de cientificidade. Na teoria e técnica dos testes sempre um mesmo aspecto é privilegiado: o esquema explicativo biológico. Com ele, as desigualdades sociais são justificadas:

[...] os trabalhos de Binet encontram um terreno de aplicação imediata na Grã-Bretanha e nos Estados Unidos, onde a ideologia global do progresso, da eficácia, do rendimento, se encarna mais imediatamente nas práticas de seleção. A preocupação maior é encontrar um 
instrumento de predição; quanto mais os prognósticos dos testes são confirmados, mais trazem a prova da realidade substancial que medem: as aptidões. [...] $\mathrm{O}$ recurso à noção de aptidão permite justificar as desigualdades sociais, pois a escola supostamente oferece a todos as mesmas oportunidades de provar as suas 'verdadeiras' aptidões verbais, numéricas, mnemômicas, etc (BISSERET, 1979, p. 49).

A ciência dos testes, segundo a autora, permite conciliar duas idéias incompatíveis: necessidade de oferecer oportunidades iguais a todos e, por outro lado, manter e justificar as desigualdades de posição profissional e social. O termo aptidão seria, dessa forma, mais propriamente “adaptidão” (NAVILLE, 1945 apud BISSERET, 1979).

A hierarquia das dimensões psicológicas prevalece para explicar as desigualdades sociais mesmo quando se questiona, no meio científico, o conceito de aptidão. Outros conceitos são colocados em seu lugar: sexo, raça, meio social, riqueza material, formação cultural.

Os estudos científicos, especialmente psicológicos, furtam-se à pesquisa da gênese das desigualdades sociais, explicando-as por meio de categorias da natureza individual:

[...] O erro resulta do método adotado e do postulado que o funda inconscientemente, ou seja, o da existência de um dado essencial. Mesmo que as desigualdades de realização escolar ou social sejam relacionadas com os indivíduos, com sua diferença de patrimônio genético, com os "meios" ou com sua diferença de nível cultural, lingüístico, etc., o esquema de pensamento não é obrigatoriamente diferente. Se uns substancializam as aptidões, outros arriscam-se a substancializar as diferenças culturais. Nesse sentido, certos sociólogos, buscando explicar as desigualdades na escola partindo da constatação das diferenças de linguagem entre as classes sociais, referem-se a um esquema fixista, em última instância análogo àquele que denunciam, ao criticar a teoria dos dons ou das aptidões. A referência central é uma linguagem de classe, a da classe burguesa, definida por suas qualidades de complexidade, de abstração; a linguagem das outras classes é definida por uma ausência: ela não é nem rica, nem complexa, etc. Ora, o que faltaria assinalar é que a linguagem "pobre" e a "falta" de cultura de alguns são as condições da linguagem "rica” e da "cultura" de outros (BISSERET, 1979, p. $60)$. 
Assim, o esquema de pensamento nascido no século XIX que explica as desigualdades sociais por meio das supostas desigualdades naturais entre os indivíduos permanece até os dias atuais. A escola é um lugar privilegiado de permanência dessa ideologia. As reformas escolares foram e são fundamentadas na ideologia das aptidões naturais. Para alunos pobres, por exemplo, “mal nutridos”, “sem formação cultural” são criados cursos técnicos, profissionalizantes, uma vez que suas habilidades não permitem que freqüentem cursos universitários.

A psicologia nasce, portanto, para dar legitimidade às desigualdades sociais, tornando-as naturais. A aptidão designa, segundo Bisseret (1979), uma característica inata, natural e causal irreversível.

Inserindo-se sobretudo nos meios escolares, desde seu surgimento como ciência, a psicologia vem para legitimar o ilegítimo, naturalizar o histórico e selar o destino dos indivíduos das classes populares.

Como tais idéias se introduzem na escola?

\subsection{A Escola Nova e a psicologia}

Para compreender como a psicologia se inseriu na formação de professores e na escola é preciso retornar à idéia de renovação escolar proposta pela chamada Escola Nova, que teve seu início no fim do século XIX.

Segundo Lourenço Filho, em "Introdução ao Estudo da Escola Nova", publicado pela primeira vez em 1929, a Escola Nova pode caracterizar-se por um conjunto de princípios tendentes a rever as formas tradicionais de ensino, a partir da expansão das escolas no século XIX, momento no qual as crianças deixaram de ser educadas apenas no seio da família. O interesse pedagógico que antes era apenas pelo ato de ensinar - e por isso o recurso da didática - passa a ser pelo ato de aprender, tornando-se necessário compreender o processo de desenvolvimento infantil e suas condições individuais.

Após a Segunda Guerra Mundial, a escola passou a ser considerada como solução para o progresso do homem e para o reequilíbrio da sociedade e o ensino 
transformado em instrumento de construção política e social. A fé no poder da educação para a revisão de valores sociais e morais trazia a necessidade de se conhecer o educando. De acordo com Lourenço Filho (1978, p. 36-37):

Não se educa a alguém senão na medida em que se conheça esse alguém; e não será eficiente o trabalho do mestre se ele não tiver uma visão clara dos recursos do educando, a fim de que, em cada caso, possa proporcionar as situações mais desejáveis, ou indicadas para a consecução dos propósitos que possa ter em vista [...]. A renovação educativa de nosso tempo teria, assim, de começar pela descoberta da criança, a qual só nos meados do século passado começou a ser feita (grifo do autor).

Os conhecimentos, até então suficientes para conduzir o ato de ensinar, não se mostravam satisfatórios para compreender o educando. Dessa forma, surgiu o ramo da Biologia Educacional e da Psicologia da Educação ou Psicologia Educacional - dividida em Psicologia Evolutiva ou das Idades; Psicologia da Aprendizagem; Psicologia das Diferenças Individuais; Psicologia dos Anormais; Psicologia das Matérias de Ensino e Psicologia da Personalidade - que produziram novos conhecimentos sobre o desenvolvimento das crianças.

O movimento da Escola Nova propôs, então, a revisão dos meios de educar, em função do conhecimento da natureza do desenvolvimento infantil e da análise das finalidades da escola. Com os estudos da Biologia Educacional surge a idéia do crescimento sucessivo e progressivo e também a visão de que o meio influencia o desenvolvimento das crianças:

Iniciou-se o estudo racional das construções escolares e de adaptação do mobiliário destinado às crianças; defendeu-se a idéia de serviços médico-escolares de ação permanente; discutiram-se delicadas questões relativas à fadiga dos escolares, com reflexo nos princípios de organização de horários, tempos de trabalho e recreio, e organização dos programas de ensino (Id. Ibid, p. 52).

A psicologia era considerada relevante para o entendimento dos processos de desenvolvimento infantil a partir do momento em que se constituiu como uma ciência objetiva que utilizava métodos quantitativos de avaliação dos fenômenos. Tornou-se importante, pois trouxe a possibilidade de aperfeiçoamento da educação na medida em 
que se conhecesse melhor a criança. O progresso da psicologia ocasionava, assim, o progresso das ações educativas. Conhecer significava predizer e controlar o que aconteceria com a criança e a ação de educar fundou-se nessa convicção:

\begin{abstract}
Em todos os tempos, as concepções teóricas, como as soluções práticas da educação, têm estado na dependência do estudo dos fatos psicológicos. Examinem-se diferentes definições de educação, antigas e modernas, e ver-se-á que elas têm sempre considerado o comportamento do educando como processo global. As mais das vezes, essas definições contêm termos usuais da psicologia, como alma, espírito, faculdades, aptidões, hábitos, interesses, ajustamento, personalidade. Quanto às técnicas educativas, bastará lembrar que todas partem da idéia de uma interferência nas formas de sentir, pensar ou agir do educando - seja para acentuá-las ou reforçá-las ou, ao contrário, alterá-las, contê-las ou combiná-las em novos padrões. A intenção de educar pressupõe a possibilidade de modificar o comportamento do educando, e a idéia correlativa de que nele existe plasticidade, cujas condições hão de ser conhecidas para que os procedimentos didáticos nelas se apóiem (LOURENÇO FILHO, 1978, p. 59-60).
\end{abstract}

A psicologia permitia, em resumo, intervir e controlar o comportamento do educando e, por esta via, aumentar a eficácia do ensino. Em primeiro lugar, fez a descrição das variações psicológicas por meio das idades, com a caracterização quantitativa do desenvolvimento infantil. Com isso, foi possível traçar perfis psicológicos normais e anormais. Conceitos como inteligência global e integral e maturação fizeram parte da descrição de cada período evolutivo da vida infantil, que passou a exigir cuidados especiais. Para que servia tal conhecimento? Lourenço Filho (1978) considera que os mestres podiam organizar seus planos de intervenção ou suas técnicas educativas sobre as crianças com base em seu crescimento evolutivo gradual e cumulativo.

A psicologia também realizou a descrição das semelhanças humanas, das diferenças individuais e dos níveis de anormalidade. Para tanto, utilizou-se de testes, que passaram por critérios de validade e fidedignidade, de acordo com os parâmetros de uma ciência objetiva, e determinou o comportamento anormal em comparação com o normal. Os testes de QI tornaram-se instrumentos valiosos para diagnosticar as crianças anormais ou crianças-problema. As aptidões, o comportamento motor, a maturidade, a 
adaptação social e emocional de cada criança foram comparadas com o que se esperava de uma determinada faixa etária. A inteligência numérica, a memória de formas, a percepção espacial, a fluência verbal, a capacidade indutiva tornaram-se fatores considerados nas avaliações do desenvolvimento infantil. Para Lourenço Filho (1978), o educador pôde, assim, encontrar pontos de referência para escolher as técnicas a serem utilizadas com grupos homogêneos de educandos.

Deste modo, a psicologia contribuiu para a criação de um modelo explicativo genético-funcional do comportamento humano e do processo de adaptação dos alunos. Educar era a possibilidade de interferir nesse processo.

Os estudos de psicologia, no movimento inaugurado pela Escola Nova, prometiam alcançar as razões determinantes da ação humana, penetrando em sua natureza. Para o autor, isto possibilitou tornar mais eficientes as técnicas que diziam respeito ao ajustamento das pessoas e ao ato de educar.

As teorias da aprendizagem ${ }^{4}$ consideravam que tudo o que fazemos e somos foi aprendido. Tornou-se fundamental, dessa forma, entender o processo pelo qual os indivíduos aprendem. Aprender, segundo o autor, é sinônimo de adquirir novos padrões de ajustamento ou de adaptação. Um fator que muito interfere no ato de aprender é a motivação:

De modo geral, a aprendizagem se caracteriza como variação do comportamento por efeito da experiência. A noção leva a reconhecer fatores dinâmicos, os de motivação, sem a qual nenhum exercício, treino ou prática se faz possível; implica depois modificabilidade funcional dos indivíduos, segundo certas características do ambiente que se tornam seletivas para a direção das reações; e, enfim, a existência de resultados cumulativos ou continuados da prática (LOURENÇO FILHO, 1978, p. 90).

A função da educação pode ser então compreendida como a de incentivar formas de ajustamento normal.

\footnotetext{
${ }^{4}$ De acordo com Lourenço Filho (1978), as teorias da aprendizagem que influenciaram o movimento da Escola Nova foram três: a do Condicionamento, que possibilitava a modificação de respostas, instalando novos padrões de ajustamento, tendo como principais representantes Pavlov, Watson e Skinner; a Aprendizagem por Ensaio e Erro, representada por Thorndike e a Aprendizagem mediante apreensão de formas ou configurações, principalmente com os estudos de Kohler. Apesar de suas visíveis diferenças, o autor considera que as três teorias são convergentes e se complementam.
} 
Outro elemento essencial que a psicologia introduziu nos meios educacionais foi o conceito de personalidade. Apesar de não haver consenso quanto ao seu significado, seu estudo permitiu a identificação da normalidade ou anormalidade dos indivíduos, com base em critérios estatísticos. A personalidade “[...] pode ser descrita com a enumeração de atributos da pessoa, grau das capacidades que revele, e intensidade dos motivos que a impulsionem; também de modo sintético, por aspectos globais de seu ajustamento, quer os consideraremos normais ou não” (LOURENÇO FILHO, 1978, p. 104).

O importante, para o autor, era traçar perfis de personalidade de modo quantitativo, úteis para diagnóstico geral, práticas de orientação profissional, seleção de empregados e problemas gerais de ajustamento.

O autor considera que, por toda a infância e adolescência, a ação educativa pode interferir na direção ou redireção das formas de ajustamento, ou seja, da personalidade, apesar das condições de vida no lar apresentarem inegável preponderância em sua determinação. O objetivo central da educação é “formar personalidades, desenvolvê-las, aperfeiçoá-las” (Id. Ibid., p. 106).

Observa-se, a partir da análise das idéias de Lourenço Filho, que a psicologia aparece no movimento da chamada Escola Nova como um recurso de controle, previsão e modificação, pelo professor, dos comportamentos dos alunos. O entendimento do desenvolvimento normal e anormal serviria como auxílio para a solução de problemas que pudessem surgir na relação com os educandos. A psicologia trazia a ilusão do controle absoluto do processo de ensino e aprendizagem.

Embora esta tenha sido a principal via de entrada da psicologia na educação, uma questão se coloca: como esta área do conhecimento se configura atualmente na escola e na formação de professores?

\subsection{A psicologia na pesquisa sobre a formação de educadores}

Em investigação sobre o papel da Psicologia da Educação na formação do professor, Caparroz (1992) discute a maneira como esta disciplina estrutura-se em 
Faculdades particulares do município de São Paulo, tendo como objetivo conhecer sua contribuição para a formação docente nos cursos de licenciatura destas instituições. Para tanto, busca verificar como as licenciaturas e os cursos de Psicologia da Educação estão organizados; quais as concepções psicológicas mais freqüentes e a articulação entre elas e a prática do professor em sala de aula. A posição da autora sobre o lugar desta disciplina na formação é definida nos seguintes termos:

Acreditamos que, longe de ser uma área que embasa-se numa única perspectiva teórica, é um campo que, fundamentando-se em diferentes conhecimentos produzidos pela ciência psicológica, colabora na reflexão sobre as questões educacionais. Nos cursos de formação de professores [...] ela [a psicologia] deve fazer parte dos fundamentos da educação, juntamente com as disciplinas História da Educação, Sociologia da Educação e Filosofia da Educação (CAPARROZ, 1992, p. 111).

A autora destaca ainda que, ao longo da história da psicologia, formou-se a crença de que ela é uma ciência capaz de solucionar todos os males da escola e/ou do ensino. Contudo, considera ser apenas uma das disciplinas responsáveis pela formação do professor e que os problemas da escola, como o fracasso escolar, podem estar relacionados à má formação do educador em geral, compartilhando, assim, com a visão de que os problemas da escola podem ser resolvidos com o aperfeiçoamento docente ${ }^{5}$.

Para compreender a organização dos cursos de Psicologia da Educação nas licenciaturas, a autora aplicou questionários nos responsáveis administrativos das licenciaturas das instituições pesquisadas e nos docentes ministrantes das disciplinas de psicologia. Entrevistou alguns destes professores com o intuito de obter mais detalhes sobre suas experiências na formação de futuros educadores, bem como para conhecer o modo como concebem e ministram a matéria.

A partir dos dados obtidos nos questionários e nas entrevistas, Caparroz concluiu que a disciplina Psicologia da Educação, nos cursos investigados, é organizada numa pequena carga horária, sem contribuir para a formação dos professores e apresentada de forma desarticulada da realidade de sala de aula do ensino fundamental e médio:

\footnotetext{
${ }^{5}$ Veremos, no último capítulo, que esta é uma perspectiva limitadora da formação, pois a compreende como aquisição de metodologias, muitas vezes provenientes da psicologia, como forma de aperfeiçoamento das relações ensino-aprendizagem, configurando-se como uma abordagem meramente técnica da formação.
} 
A Psicologia da Educação adquire, conseqüentemente, diferentes papéis e cumpre diferentes funções na ótica desses professores. Com isto, perdem-se ricas oportunidades de fazer, da Psicologia da Educação, uma disciplina que se coloque, efetivamente, a serviço da prática pedagógica ${ }^{6}$. Constatamos, com pesar, que a Psicologia da Educação parece ser matéria tão somente formal nos cursos de Licenciatura, não atingindo nem mesmo os objetivos mais modestos que dela se espera (Id. Ibid., p. 170-171, grifo nosso).

No levantamento bibliográfico sobre o tema "formação de professores em psicologia”, realizado no sistema Sibi-Dedalus da Universidade de São Paulo, constatamos a existência de um número muito reduzido de livros, dissertações e teses que tratem diretamente do assunto em questão. A maioria deles se refere à formação de educadores em geral e, quando menciona a formação em sua relação com a psicologia, geralmente trata de alguma dimensão da realidade escolar, apontando a psicologia como suporte para possíveis intervenções em áreas específicas, como indisciplina, motivação, aprendizagem, comportamento, dentre outras.

Todavia, localizamos um livro que trata especificamente do tema "formação de professores e psicologia”, de autoria de pesquisadores do Grupo de Estudos e Pesquisas Psicologia e Educação Superior, vinculado à Faculdade de Educação da Universidade Estadual de Campinas - UNICAMP. Trata-se de Formação de Professores: Discutindo o Ensino de Psicologia, organizado por Azzi; Batista e Sadalla (2000) ${ }^{7}$.

Os capítulos, que serão apresentados um a um, tratam do lugar da disciplina Psicologia da Educação nos cursos de licenciatura, pretendendo criticar uma concepção de formação rápida, ágil, instrumental, fundada no “como fazer”.

Os autores apontam que a obrigatoriedade das disciplinas relacionadas à Psicologia da Educação, subdivididas geralmente em Aprendizagem e Adolescência, é

\footnotetext{
${ }^{6}$ Novamente, aqui, percebe-se que a psicologia é vista como possibilidade técnica de melhorar a prática pedagógica.

${ }^{7}$ Todos os capítulos foram escritos por professores da Universidade juntamente com alunos da graduação e da pós-graduação.
} 
desejada pelos órgãos oficiais de ensino, porque delas dependeria a possibilidade da construção das competências para ensinar. No contexto da crítica à formação tecnicista, o livro aborda em linhas gerais três temas: a) desenvolvimento profissional e constituição da docência, b) o ensino de psicologia nas licenciaturas e c) contribuições da psicologia à prática pedagógica.

O primeiro capítulo, do primeiro tema, Teorias implícitas na ação docente: contribuição teórica ao desenvolvimento do professor prático-reflexivo, faz uma revisão bibliográfica das pesquisas sobre o pensamento do professor (crenças e idéias) e suas implicações para a ação docente. As autoras tratam da formação do professor em geral e não da formação em psicologia especificamente. Colocam como ponto principal da formação a exigência da prática centrada na reflexão coletiva, linha de pesquisa surgida em 1974, nos Estados Unidos. Desde então, as pesquisas têm se voltado para a investigação sobre as teorias e crenças que embasam o pensamento do professor e suas implicações para a ação docente. As crenças são “[...] as idéias fundamentais das pessoas a respeito de suas experiências de vida e afetam diretamente as suas ações, quer se admita conscientemente estas crenças, quer não" (SADALLA; WINIVESKY; PALUCCI; VIEIRA, 2000, p. 24). Crença, nesta concepção, tem sido adotada como sinônimo de teoria e de perspectiva.

O professor, neste contexto, é considerado um profissional em contínuo desenvolvimento, na medida em que toma sua própria ação como objeto de reflexão e análise. Ele atua como sujeito na formulação de propósitos e objetivos de seu trabalho, de estratégias e meios para atingir suas metas: “Trata-se, portanto, de um profissional prático-reflexivo, uma vez que desenvolve suas teorias e práticas debruçando-se sobre o conjunto de sua ação e refletindo sobre seu ensino e sobre as condições sociais nas quais suas experiências estão inseridas” (Id. Ibid., p. 25).

Desta perspectiva, mudanças nas crenças do professor geram mudanças na prática educativa. Os educadores atuam de acordo com suas teorias e crenças, mesmo que não estejam conscientes disso. É preciso estudar e pesquisar as crenças para modificar e aperfeiçoar a prática ${ }^{8}$.

\footnotetext{
${ }^{8}$ Poderíamos supor, então, que os problemas da escola, para as autoras, devem ser solucionados com o aperfeiçoamento docente.
} 
Sugerem também a substituição dos termos aperfeiçoamento, reciclagem, formação em serviço e formação permanente pelo conceito de desenvolvimento profissional, que abrange desde a formação inicial até a formação continuada. O processo de formação ocorre ao longo da vida e cada professor é responsável pelo seu próprio desenvolvimento ${ }^{9}$. As etapas da formação se constituem em: conhecimento na ação, reflexão na ação e reflexão sobre a ação. O processo de aprendizagem do professor deve se dar na ação ${ }^{10}$; é a reflexão sobre a ação praticada. Diante das diversas situações inesperadas que o docente encontra em sala de aula, ele precisa tomar decisões:

Isto significa que não é possível que se possa formar o professor para que ele seja capaz de prever a conseqüência de cada um dos atos em sala de aula. Mas, ao contrário, pode-se contribuir para que ele, municiado de uma teoria com a qual comungue, seja capaz de atuar na direção daquilo que pretende alcançar [...]. Diferentemente do médico ou advogado, muitas vezes o professor não pode "pedir vistas ao processo" ou "solicitar novos exames" para que melhor subsidie sua conduta. O professor deve tomar imediatamente uma decisão, sob o risco de desviar as aprendizagens ou as atitudes dos alunos. Assim, é fundamental que ele tenha clareza dos objetivos e metas que pretende atingir, bem como, baseado numa determinada teoria saiba avaliar de forma mais adequada aquela que seria a melhor maneira de solucionar um problema (SADALLA; WINIVESKY; PALUCCI; VIEIRA, 2000, p. 31, grifo nosso).

O objetivo último da formação seria, então, tornar o professor consciente de suas crenças ou teorias que de alguma maneira fundamentam sua prática, para que possa refletir sobre a ação praticada. Segundo as autoras, os cursos de aperfeiçoamento e reciclagem não dão conta deste processo de reflexão, pois geralmente prescrevem ações que o docente deve executar em sala de aula. Ao contrário, o professor que reflete sobre sua ação está mais capacitado a desenvolver no aluno atitudes mais autônomas:

Deste modo, não basta reciclar os professores em cursos que objetivem mudar sua ação no processo ensino-aprendizagem. É fundamental que ele seja auxiliado a refletir sobre sua prática, a organizar suas próprias teorias, a compreender as bases de suas crenças sobre este processo, de modo que, tornando-se um

\footnotetext{
${ }^{9}$ Esta é a meta da perspectiva liberal: cada indivíduo é responsável por seu êxito ou fracasso.

${ }^{10}$ A idéia presente é a de que "só se aprende fazendo".
} 
pesquisador de sua ação, possa contribuir sobremaneira para a melhoria do ensino ocorrido em sala de aula (Id. Ibid., p. 32).

Sobre esse capítulo, em primeiro lugar, vale destacar que qual teoria irá subsidiar o trabalho docente parece não ter grande relevância, desconsiderando as diferenças práticas e políticas entre elas. Além disso, apesar da mudança de termos, parece que a idéia de melhorar, aperfeiçoar a prática do professor ainda é preponderante.

No capítulo Desenvolvimento profissional do professor: desafios institucionais, que integra o primeiro tema, Leite (2000), ao tratar também da formação em geral e não da formação em psicologia, afirma que o modelo tradicional de formação era caracterizado por uma perspectiva tecnicista, que tinha uma concepção centralizadora da gestão escolar. Sua proposta para a formação se contrapõe ao modelo tradicional que divide os produtores do conhecimento (pesquisadores e especialistas) e os aplicadores (professores em sala de aula) e põe como alternativa ao tecnicismo o conceito de desenvolvimento profissional, questionando a concepção da formação inicial como a única e principal condição de formação. Considera que a formação é um continuum e que a inicial é apenas uma das etapas. No processo de desenvolvimento docente, o papel central é o da experiência ou da prática, pois ela é a “matéria bruta”, eixo fundamental da formação ${ }^{11}$ :

A produção do conhecimento do professor inicia-se pelo questionamento da prática, respaldando-se em conhecimentos teóricos, sendo que seu produto corresponde à ampliação do entendimento dos problemas vivenciados e a novas soluções para a superação dos problemas. Daí a necessidade do professor inserir-se na prática, desde sua formação inicial, envolvendo, obviamente, todo o processo posterior de educação continuada (LEITE, 2000, p. 47).

O grande objetivo do processo seria formar o professor reflexivo. Seu êxito depende, segundo o autor, da capacidade de manejar situações complexas e resolver problemas práticos, por meio da integração do conhecimento e da técnica. O pensamento prático do profissional é composto por: a) conhecimento na ação, b) reflexão na ação e c) reflexão sobre a ação e sobre a reflexão na ação. A reflexão por si não salva o processo de formação, que depende da qualidade da reflexão; por isso ela deve ser

\footnotetext{
${ }^{11}$ Destaca-se, nesse sentido, a primazia da prática em oposição à teoria. Esta é instrumento daquela.
} 
centrada na prática. A formação deve auxiliar o docente a construir sua identidade profissional, por meio de três etapas: 1 . Desenvolvimento pessoal - produzir a vida do professor; 2. Desenvolvimento profissional - produzir a profissão docente e 3. Desenvolvimento organizacional - produzir a escola.

Para que a formação continuada seja um processo crítico-reflexivo, é necessário, de acordo com Leite (2000), que se desenvolva um trabalho coletivo na escola para romper com as formas individualistas e hierarquizadas de organização entre os que pensam e os que executam. O trabalho coletivo permite visualizar a totalidade do processo educacional. Além disso, é necessário o exercício da reflexão crítica, que se dá sempre a partir da prática do professor. O processo ativo e contínuo de reflexão sobre a prática leva ao processo de formação permanente.

A formação do professor prático-reflexivo contribuiria, segundo o autor, para o estabelecimento da escola democrática, que proporciona o acesso e a permanência de todos com qualidade na escola, ou seja, garante o sucesso do aluno.

Dando início ao tema $O$ ensino de psicologia nas licenciaturas, encontramos o capítulo Conhecimento psicológico e formação de professores, no qual Guerra (2000) põe a psicologia como subsídio ao docente nos processos de desenvolvimento e de aprendizagem dos alunos. A psicologia, como disciplina pedagógica dos currículos das licenciaturas, é responsável pelo embasamento teórico da atividade profissional, participando do processo de capacitação docente para o exercício do magistério.

A autora apresenta um panorama histórico da relação da psicologia com a educação, afirmando que ela surge na escola a partir da necessidade de se introduzir mudanças qualitativas no ensino, relacionadas à solução de problemas. Após a ênfase nas questões de desenvolvimento e aprendizagem e, portanto, nos alunos, a psicologia traz as questões relacionadas à instrução e, assim, o foco passa a ser o ensino e a formação de professores:

Num esforço conjunto, a Psicologia da Educação focalizaria o estudo dos aspectos psicológicos dos sujeitos que participam de atividades educativas, preocupando-se tanto com o processo de aprendizagem quanto com as condições do ensino. Assim, a Psicologia da Educação passa a gerar conhecimentos em três direções: apresentando explicações, criando estratégias de planejamento e oferecendo técnicas e instrumentos para intervenção nas práticas 
educativas, o que de certa forma redefine o caráter da sua aplicabilidade $^{12}$ (GUERRA, 2000, p. 74, grifo nosso).

Considerando que as teorias da psicologia sempre estiveram presentes na formação do educador, a autora faz uma análise das implicações de algumas delas para a educação: o behaviorismo, a teoria piagetiana e a abordagem histórico-cultural de Vygotsky. Identifica no behaviorismo a entrada principal do tecnicismo na educação e afirma que o problema essencial da formação é a fragilidade teórico-metodológica dos cursos formadores. A psicologia, se bem estruturada, poderia ser uma disciplina instrumental nos cursos de licenciatura, a fim de que os professores pudessem conhecer aspectos do desenvolvimento e modelos de aprendizagem. Ela proporcionaria o estudo, a compreensão e a intervenção nos fenômenos educativos. A autora apresenta também um panorama de como a disciplina Psicologia da Educação está mal estruturada nos cursos de formação, encontrando problemas como a desarticulação entre teoria e prática e o distanciamento da realidade escolar. Aponta a necessidade de se refletir sobre os conteúdos trabalhados, os procedimentos adotados e as articulações com as demais áreas do conhecimento.

Acredita que a questão principal para a formação atualmente é quais conhecimentos de psicologia devem ser ensinados para subsidiar melhor o professor em sua prática pedagógica. A Psicologia da Educação, de acordo com sua análise, deve apresentar as diferentes abordagens teóricas e sua compreensão crítica para que o futuro professor entenda suas implicações na prática educativa. Conclui que a teoria históricocultural de Vygotsky traz importantes contribuições para a formação de professores:

A formação docente, nesta perspectiva, estaria contribuindo para a constituição de professores envolvidos ativamente na apropriação do conhecimento, habilidades, valores da cultura e conhecimentos sobre o aluno, que são indispensáveis à sua atuação como profissional da educação. A formação assumiria o significado de processo de constituição e desenvolvimento do ser humano. Dessa forma, a Psicologia estaria desempenhando importante papel na constituição de conhecimentos e competências, que viriam contribuir com a melhoria na formação de professores nos cursos de licenciatura e,

\footnotetext{
${ }^{12}$ A psicologia permite, nesse sentido, conhecer o indivíduo em seus processos psicológicos e instrumentar os docentes para ensiná-los. Uma questão importante que será discutida mais adiante, nas páginas 164 a 169: trata-se dos aspectos psicológicos de sujeitos e não de alunos.
} 
conseqüentemente, com a qualidade do ensino básico (GUERRA, 2000, p. 92).

Fundamentalmente a proposta da autora visa à melhoria da formação de professores por meio do ensino mais adequado da psicologia. A pretensão de aperfeiçoamento de recursos técnicos de ensino pressupõe que os problemas escolares têm suas raízes nesse âmbito. Cabe perguntar se a psicologia proposta dá conta da instituição escolar, dos alunos e dos professores, ou seja, dos determinantes sociais, culturais, econômicos e políticos que estruturam o que se denomina "escola”.

O texto, do segundo tema, Discutindo a relação professor-licenciado e alunoadolescente à luz da formação em psicologia (ALMEIDA, 2000) discute o papel da psicologia na formação do professor a partir da tríade aluno-adolescente, professorlicenciado, formação-psicologia. A formação do professor deve contemplar: a integração do conteúdo específico com o pedagógico; a articulação dos conteúdos com a realidade escolar; a articulação entre teoria e prática; a vivência da relação teoria e prática; atividades de pesquisa e o trabalho coletivo.

No caso dos cursos de licenciatura, a autora ressalta que os docentes ali formados irão trabalhar com os adolescentes do ensino fundamental, desde a quinta-série até o ensino médio, o que exige um conhecimento específico sobre a adolescência:

Da mesma forma que para ensinar a criança é preciso compreender como se dá o processo de desenvolvimento e aprendizagem, para melhor atender as suas necessidades, levando os educadores a tomarem consciência do tempo e do espaço de que ela necessita para desenvolver suas potencialidades, ensinar o adolescente também exige a compreensão do que ocorre com o jovem, tanto biológica quanto cognitiva, psicológica e socialmente ${ }^{13}$ (ALMEIDA, 2000, p. 101).

Os conhecimentos sobre adolescência reúnem um conjunto de idéias relativas à descrição e à explicação dos processos de mudança do ser humano. Tais saberes devem ser disponibilizados pela psicologia durante a formação. A necessidade de que o professor domine o processo de desenvolvimento do aluno-adolescente se dá a partir do momento em que se considera que a eficácia do trabalho do professor gera a eficácia do

\footnotetext{
13 O mesmo objetivo se repete: conhecer o indivíduo para ensinar, dominar seu processo de desenvolvimento para melhorar a aprendizagem.
} 
aprendizado do aluno. A psicologia, segundo a autora, é uma das áreas que pode proporcionar a melhor atuação docente:

\begin{abstract}
Como se pode perceber, a Psicologia tem um papel que se traduz tanto pelas possibilidades quanto pelas limitações. Possibilidades, como fonte de conhecimento sobre os processos de aprendizagem e desenvolvimento humano; limitações, na medida em que a complexidade pedagógica só pode ser entendida se considerarmos a teia de relações entre os seus diferentes e contraditórios aspectos, o que significa que a Psicologia não pode sozinha explicar a realidade escolar (ALMEIDA, 2000, p. 105).
\end{abstract}

De acordo com a autora, a formação do professor deve abranger conteúdos que considerem o aluno que o professor tem diante de si, a realidade educacional, escolar e social e as diferentes contribuições da psicologia.

No que se refere à compreensão sobre o período da adolescência, destaca a importância de se romper com o estereótipo de "tempestade e tormenta” desta fase do desenvolvimento humano. A formação, portanto, não deve tratar o adolescente como rebelde, imediatista, a fim de que o professor saiba o que fazer em sala de aula para alcançar um ensino mais eficiente. Desta forma, o papel da psicologia na formação do professor licenciado é contribuir para a construção da sua concepção sobre adolescência/adolescente; parte-se do pressuposto de que ter conhecimentos sobre adolescência gera mais eficácia no ensino. Estas concepções estão muito próximas da Escola Nova...

Já o capítulo $O$ ensino de psicologia da educação sob o olhar de licenciados $e$ licenciandos, também do segundo tema, buscou, por meio de pesquisa, avaliar as contribuições da psicologia em cinco licenciaturas de uma Universidade: Matemática, Letras, História, Geografia e Ciências Biológicas. Participaram do estudo professores formados na instituição que atuam no ensino público e particular, alunos-graduandos, coordenadores das licenciaturas e professores das disciplinas Prática de Ensino e Estágio Supervisionado. Foram aplicados questionários e feitas entrevistas com os participantes.

A autora considera que pesquisar como os alunos e ex-alunos dos cursos de licenciatura compreendem a qualidade do ensino que lhes foi oferecido permite intervir 
na formação. A psicologia é considerada, nesse capítulo, como área do conhecimento que fornece recursos ao educador para analisar e interferir no fenômeno educativo:

Entende-se que nenhum professor minimamente responsável com sua tarefa poderá desprezar instrumentos reflexivos acerca do processo de aprendizagem, do desenvolvimento intelectual, do desenvolvimento afetivo, do processo de socialização do ser humano, de como e porque alguém é motivado para determinada busca, para interagir com seus pares, e ao meio de tudo isso, diferenciar-se e assemelhar-se ao seu grupo humano, familiar, social, cultural constituindo-se uma singularidade ${ }^{14}$ (LAROCCA, 2000, p. 122, grifo nosso).

A pesquisa com os envolvidos no processo de formação constatou, em relação à disciplina Psicologia da Educação, que: a) há desarticulação entre teoria e prática; b) há insuficiência da carga horária da disciplina; c) os formadores são incapacitados e não comprometidos com o seu trabalho e d) há desvinculação da psicologia com a área específica de formação.

Segundo a autora, os licenciandos e licenciados, participantes da pesquisa, esperam que a Psicologia da Educação trate de temas que estão sendo exigidos pela realidade, como interações escolares, educativas e exigências mais amplas da sociedade. A disciplina deve permitir aos professores um conhecimento mais concreto do aluno, contemplando como ele aprende, como se dá seu desenvolvimento cognitivo, social e afetivo, sua situação sócio-existencial no mundo. Larocca (2000, p. 132) conclui que:

No entanto, se as Licenciaturas são cursos de preparação profissional prévia de professores (e, repetir-se-á “de professores”), é inconcebível que uma área de conhecimento tão importante quanto a Psicologia da Educação, que dá a conhecer sobre o aluno, seja colocada, como tem sido, na periferia da formação. Conhecer o aluno é, para alguém que se prepara para professor, tão importante quanto conhecer as funções vitais do ser humano para alguém que se prepara para ser um médico ${ }^{15}$. Nem um, nem outro, pode atuar sem esse tipo de conhecimento. Todavia, não raras vezes supõe-se que um professor possa ir para a sua sala de aula munido de conteúdos, metodologias e vontade política, sem considerar o funcionamento cognitivo psicológico de seu aluno, a exemplo de um médico que vai visitar seu paciente para curá-lo portando comprimidos e estetoscópio, mas esquecendo de levar em conta que ele já não digere (grifo nosso).

\footnotetext{
${ }^{14}$ Onde está o aluno e a escola?

15 Aqui novamente estão presentes objetivos postos pela Escola Nova: é necessário conhecer o desenvolvimento psicológico dos alunos para ensinar.
} 
Conhecer o funcionamento cognitivo psicológico do aluno é fundamental, mas por quê? Inicia-se aqui o pressuposto de que cada indivíduo deve ser conhecido em profundidade. Tal tarefa parece exigir um professor particular para cada aluno...

No tema Contribuições à prática pedagógica, encontram-se dois textos. No primeiro, Ensinando psicologia na licenciatura: experiências, opções e aprendizagens, Batista e Azzi (2000) contam suas experiências como ministrantes das disciplinas Psicologia Educacional - Aprendizagem e Psicologia Educacional - Adolescência em alguns cursos de licenciatura da UNICAMP (Matemática, Física, Química, Ciências Sociais, Artes e Letras), nos anos de 1998 e 1999. A partir da crítica à redução do processo educativo às variáveis psicológicas, fizeram uma mudança no conteúdo das disciplinas, inserindo temas como representações sobre bom professor, aluno, ensino, aprendizagem, educação, além de cotidiano educacional, violência e drogas, sexualidade, autoridade e disciplina.

A proposta feita aos licenciandos tinha como eixo a observação, o estudo e a análise de práticas educativas (escolares e não escolares) sob a perspectiva psicológica. Para viabilizá-la, privilegiaram o acesso à realidade educacional, introduzindo na disciplina a observação de um contexto educacional, que podia ser uma unidade de ensino fundamental, médio, superior, uma ONG, um curso pré-vestibular, um curso de educação de idosos, de educação infantil ou de educação especial.

A disciplina organizou-se da seguinte forma: a) Estudos sobre a relação da psicologia com a docência; b) Estudos sobre técnicas de observação; c) Observação do contexto educativo e d) Análise do que foi observado a partir de teorias da psicologia.

Nesse caso, a “nova” estruturação da disciplina Psicologia da Educação pressupunha que a psicologia poderia explicar o que foi observado no contexto escolar, o que nos conduz a seguinte indagação: como conhecimentos sobre processos de aprendizagem e de desenvolvimento da adolescência podem sozinhos explicar a realidade escolar observada? A mera introdução de uma atividade prática na formação docente garante o melhor entendimento do que ocorre na escola?

Finalmente, o capítulo intitulado Ensino de psicologia na licenciatura: estratégias de ensino como facilitadoras da articulação entre realidade da escola $e$ conteúdo teórico (AZZI; PEREIRA; BATISTA, 2000) analisa três estratégias de ensino 
utilizadas na disciplina Psicologia Educacional - Aprendizagem, ministrada nos cursos de licenciatura em Letras e Ciências Sociais da UNICAMP, a partir da avaliação dos alunos. As estratégias utilizadas pelas autoras foram o trabalho de campo, o seminário e o pôster/painel.

As autoras, assim como os demais autores incluídos nesse livro, consideram que a pedra angular do processo de educação docente é a reflexão. Por isso, propuseram três estratégias de ensino que pudessem garantir a reflexão do futuro professor. Apontam, ainda, que a formação refere-se à aquisição de competências, entendidas como a capacidade de agir eficazmente apoiada em certos conhecimentos. Neste sentido, a psicologia seria a disciplina responsável por oferecer os conhecimentos necessários a uma ação mais eficaz por parte do professor.

Ressaltam também que a prática é o cenário adequado para a formação e o desenvolvimento de competências, capacidades e atitudes dos profissionais, devendo ser o eixo central do currículo da formação docente. As teorizações da psicologia procurariam oferecer subsídios à prática educativa: "Desta forma, a formação do futuro professor deve disponibilizar práticas que estimulem o hábito de observar, de questionar e até de imitar, desde que reflexivamente, de relacionar a teoria que aprende com a prática em cada experiência ou forma de ensino estudada” (AZZI; PEREIRA; BATISTA, 2000, p. 169).

A disciplina estruturou-se, então, da seguinte forma: no trabalho de campo, os alunos observaram pelo menos duas aulas em uma escola, com um roteiro de registro; no seminário discorreram sobre teorias da psicologia e no painel realizaram uma reflexão da situação observada a partir das teorias de psicologia.

Ao final da disciplina, as docentes ministrantes solicitaram aos licenciandos sua avaliação quanto às estratégias de ensino por elas utilizadas e sua contribuição para a formação. A avaliação dos alunos foi a de que o trabalho de campo configura-se como a melhor estratégia, seguido pelo painel e, por último, pelo seminário.

Observando todos os capítulos de Formação de Professores: Discutindo o Ensino de Psicologia, verifica-se que a Psicologia da Educação aparece como uma disciplina que pode oferecer subsídios teóricos e técnicos ao trabalho pedagógico do professor, seja via formação inicial ou continuada. Os autores concordam que os cursos 
de licenciatura apresentam uma psicologia essencialmente teórica, tratando de conceitos e de autores de forma desvinculada da prática profissional do educador. A concepção de formação fundamenta-se no conceito de professor prático-reflexivo. A Psicologia da Educação, como disciplina obrigatória do currículo da formação de professores, deveria, segundo suas análises, estar mais próxima da realidade escolar. Mas, estão cientes de que esta disciplina, sozinha, não dá conta de explicar e resolver os problemas da escola.

Dos sete artigos que compõem o livro, apenas um incluiu a opinião de alunos e ex-alunos dos cursos de licenciatura, apresentando a versão dos docentes e futuros professores sobre sua própria formação. Mesmo assim, o fez por meio da aplicação de questionários, com respostas fechadas, em sua maioria. O espaço reservado para as entrevistas se restringiu aos formadores.

Além disso, os autores repõem a psicologia como técnica, instrumento ou recurso a ser aplicado pelo professor para garantir a eficácia do ensino, apesar da crítica ao tecnicismo que abre o livro. Isto pode ser observado nos vários trechos citados anteriormente, nos quais os autores descrevem a psicologia como disciplina vital para que o docente possa conhecer o processo cognitivo de seu aluno, e sem a qual a formação torna-se deficitária.

Conhecer processos psicológicos dos indivíduos parece ser o eixo fundamental da formação docente nesse livro que se propõe a criticar uma psicologia tradicional. Mantém, todavia, em seus vários capítulos, princípios já existentes nos estudos iniciais da Escola Nova.

O conteúdo do que se ensina sobre psicologia aos futuros professores não foi, em nenhum momento, questionado. As mudanças curriculares propostas dizem respeito, em sua maior parte, ao planejamento de novas estratégias para tornar o ensino de psicologia mais eficaz.

Assim, a psicologia vai ocupando espaços importantes na formação de educadores, mesmo que apresentada em um único semestre por uma disciplina, ensinando-os como conhecer crianças e adolescentes e como adequar este conhecimento a um ensino mais eficaz. Resta saber que efeitos a psicologia tem produzido nesse processo formativo. 
Poucos são os trabalhos em que é possível encontrar depoimentos de professores sobre aspectos de sua formação ou de seu próprio trabalho. Andaló (1995) colheu depoimentos dos técnicos que organizaram e ministraram um curso de aperfeiçoamento, que se propunha a tratar das Dificuldades de Aprendizagem, oferecido pela Secretaria de Educação do Estado em uma capital brasileira e de professoras de primeira a quarta séries do ensino fundamental que o cursaram.

A proposta era repensar "de dentro” o aperfeiçoamento docente realizado pelos órgãos oficiais de ensino, ou seja, a partir da visão de seus destinatários e ministrantes: "Isto significa investigar a perspectiva dos protagonistas dos cursos de aperfeiçoamento, ou seja, daqueles que os planejam e ministram e daqueles que a eles se submetem - os professores" (ANDALÓ, 1995, p. 24).

Para tanto, fez entrevistas individuais com dezessete professoras primárias que participaram do curso. A autora não analisou a categoria professora como entidade abstrata e homogênea; ao contrário propôs-se a conhecer a história pessoal e profissional de cada uma, vinculada ao que denominou “cenário da educação pública em geral”, bem como o contexto das escolas das quais as professoras faziam parte. Além disso, colheu os depoimentos das duas ministrantes e participou das etapas finais do curso, procurando caracterizá-lo quanto à organização, conteúdos, abordagem teórica, metodologia empregada e os aspectos gerais da dinâmica dos dois grupos que participaram do trabalho.

Em sua pesquisa, verificou que o aumento de cursos de aperfeiçoamento ou reciclagem oferecidos aos professores está atrelado à idéia de incompetência dos docentes como explicação para o fracasso escolar dos alunos. A visão predominante no caso em estudo foi a de que a melhora da escola pública se dará pela melhora técnica do professor.

Andaló (1995) analisou o depoimento das professoras, por meio das seguintes categorias: sua formação profissional; as relações dentro da escola; as relações com os órgãos oficiais de ensino; o regime de tempo de trabalho; o que pensam sobre o fracasso 
escolar; como vêem os educandos e suas famílias; como são os cursos de aperfeiçoamento docente - com ênfase naquele sobre Dificuldades de Aprendizagem.

Ressaltou as condições precárias nas quais as professoras trabalham e a desvalorização crescente da atividade docente. Destacou, ainda, um “desencanto” de base: as educadoras atribuem as causas do fracasso escolar a aspectos alheios a sua própria atividade, ao passo que os órgãos oficiais supõem que o insucesso escolar decorre da incompetência docente.

No que se refere ao curso analisado, constatou a frustração e revolta das professoras quando descobriram que não encontrariam respostas para as dificuldades de aprendizagem de seus alunos como desejavam, e sim passariam por cento e vinte horas de estudo sobre o desenvolvimento infantil de crianças na idade pré-escolar - e, portanto, de crianças da faixa etária com a qual não trabalhavam - segundo a teoria de Jean Piaget.

As professoras entrevistadas, apesar de, em sua maioria, avaliarem positivamente o curso, apontaram a necessidade dele estar mais próximo da realidade escolar e de seus ministrantes terem experiência de ensino com crianças:

Concluindo com relação à oferta dos cursos de aperfeiçoamento, a atitude das professoras foi ambivalente. Por um lado, julgavam-nos importantes no sentido de se constituírem numa oportunidade de rever sua prática e se atualizar [...] Em geral têm suas expectativas frustradas por se defrontar com cursos excessivamente teóricos, oferecidos numa linguagem sofisticada e inacessível, desvinculados da realidade das escolas e da prática pedagógica. Sentem-se desrespeitados e atropelados em seu saber-fazer, com a imposição de orientações arbitrárias dos "técnicos" do sistema educacional que, desconsiderando e ignorando sua experiência efetiva, decidem o que podem e devem fazer (Id. Ibid., p. 101-102).

As ministrantes avaliaram que o grupo apresentou forte resistência ao conteúdo, pois desejava soluções prontas e imediatas, não compreendendo a importância do estudo teórico, inclusive como forma de luta do professor em seu trabalho nas escolas. Porém, não questionaram a possibilidade de outros motivos para a resistência ora manifesta, ora velada dos grupos de educadores a respeito do conteúdo e da forma do curso.

Analisando o curso, por meio de sua observação direta e do depoimento das planejadoras e ministrantes e das professoras primárias, a autora constatou a existência 
predominante de uma visão tecnicista e fragmentada da ação educativa. Há a ênfase no discurso da competência; neste caso, é preciso conhecer desenvolvimento infantil para solucionar os problemas de aprendizagem. Além disso, os órgãos oficiais de ensino acreditam que o fracasso da escola se resolveria com a substituição de uma abordagem pedagógica por outra. Existe, assim, a desvalorização, por parte dos especialistas, dos conhecimentos adquiridos pelas professoras em sua prática.

Andaló (1995) denuncia a forma como estes cursos são impostos aos professores, sem considerar o que esperam e o que necessitam. Os próprios educadores demonstram a incompatibilidade da abordagem proposta pelo curso à realidade escolar, apontando também a inadequação de seu conteúdo, como conseqüência da falta de vivência e do desconhecimento dos técnicos sobre o que é a escola. Assim, a sala de aula passa a ser o único lugar onde os professores detêm o poder. Neste espaço, minam as imposições de seus superiores e trabalham de acordo com o que sua experiência mostra ser eficaz.

A autora conclui que, apesar da formação das educadoras apresentar sérias falhas, ela não pode ser a única responsável pelo insucesso da escola. É preciso analisar todo o contexto que envolve a instituição escolar. Acredita que:

Os cursos de aperfeiçoamento, pretendendo ser um dos meios de recuperar a competência dos educadores, da forma como vêm sendo oferecidos, têm se mostrado, além de dispendiosos, ineficazes. Elaborados à distância da realidade das escolas, partindo de teorias escolhidas pelos técnicos do sistema, acabam se tornando receituários inócuos, de cunho tecnicista, incapazes de transformar de modo efetivo a ação cotidiana [...] É comum os pesquisadores irem ao encontro da realidade escolar munidos de concepções teóricas elaboradas à margem da experiência, com visões idealizadas sobre o que seria "a educação" ou "o bom professor" e procurando impor padrões e normas de ação (Id. Ibid., p. 188).

Andaló (1995) termina questionando a insistência oficial em combater o insucesso da escola e a queda da qualidade de ensino por meio de cursos de aperfeiçoamento docente que querem sanar os problemas da escola pública ensinando aos professores teorias de psicologia do desenvolvimento. A autora conclui pela:

[...] importância de se "ouvirem" os protagonistas do processo pedagógico, para resgatar e conhecer o seu saber. Isto implica em ir 
ao seu encontro com o mínimo de categorias pré-formadas e de propostas prontas, e no abandono da segurança cômoda do saber "competente" e instituído. Requer, outrossim, atitude de questionamento e desconfiança de tudo o que está naturalizado e estabelecido como verdade (Id. Ibid., p. 189-190).

Gatti (2003) apresenta um programa de formação de educadores realizado no período de 2000 a 2002, destinado a docentes em serviço nas regiões Norte, Nordeste e Centro-Oeste do país. O Proformação, desenvolvido pelo Ministério da Educação, tinha como objetivo formar docentes em exercício nas regiões menos favorecidas do país, que não tinham formação para a docência - a maioria possuía apenas o ensino fundamental completo e, alguns, nem mesmo este nível de escolaridade.

O curso foi organizado na modalidade à distância, com momentos presenciais coletivos quinzenais e blocos de aulas também presenciais de quinze dias a cada semestre. Ao todo, o curso teve dois anos de duração. Os tutores se reuniam com os professores-cursistas a cada quinze dias, além de acompanharem freqüentemente os trabalhos que desenvolviam em suas salas de aula. Em média era um tutor para cada dez alunos. No total, foram atendidos cerca de quarenta mil professores das regiões mencionadas, constando apenas $10 \%$ de evasão.

A autora discute e avalia a proposta do curso de formação tendo em vista que os programas formativos que visam a mudanças em cognições e práticas partem do princípio de que elas ocorrerão a partir do momento em os professores tiverem domínio de certos conhecimentos. Gatti (2003) considera que esta concepção é muito limitada porque a formação envolve processos complexos não só cognitivos, como socioafetivos e culturais:

As limitações dessa concepção têm sido tratadas pela pesquisa e literatura em psicologia social, que chamam a atenção para o fato de que esses profissionais são pessoas integradas a grupos sociais de referência nos quais se gestam concepções de educação, de modos de ser, que se constituem em representações e valores que filtram os conhecimentos que lhes chegam. Os conhecimentos adquirem sentido ou não, são aceitos ou não, incorporados ou não, em função de complexos processos não apenas cognitivos, mas, socioafetivos e 
culturais. Essa é uma das razões pelas quais tantos programas que visam a mudanças cognitivas, de práticas, de posturas, mostram-se ineficazes. Sua centralização apenas nos aspectos cognitivos individuais esbarra nas representações sociais e na cultura de grupos (Id. Ibid, p. 192).

A ênfase em outras questões relevantes e não apenas na aquisição de conhecimentos, fez com que o curso para professores de ensino fundamental (primeira a quarta séries), trabalhadores em condições tão precárias, pudesse ser avaliado positivamente, gerando transformações significativas na prática pedagógica destes docentes.

Um primeiro aspecto considerado na avaliação do curso é que 90\% dos cursistas foram aprovados. As avaliações ocorreram periodicamente por meio de diversos procedimentos, como provas bimestrais, memorial sobre as atividades realizadas com os alunos, observação da prática pedagógica feita pelo tutor, projetos de trabalho. As mudanças foram observadas na relação professor-aluno, na articulação do conteúdo com as vivências culturais dos alunos, no planejamento e preparação das atividades docentes, no uso de recursos pedagógicos em sala de aula.

De acordo com Gatti (2003), as transformações se efetivaram, pois a proposta considerou que os professores são essencialmente sociais e não seres abstratos e exclusivamente intelectuais, como a maioria dos cursos de formação pressupõe. Os programas de formação só são efetivos, segundo sua avaliação, quando consideram as condições sociopsicológicas e culturais dos professores em seu ambiente pessoal e profissional e não apenas suas condições cognitivas:

Daí decorre ser muito simplista a noção de que o aumento e a melhoria do rol de conhecimentos informativos, adquiridos individualmente, será suficiente para melhorar ou modificar conceitos e práticas ligados ao trabalho profissional de professores. Essa concepção não dá conta da complexa dinâmica sociopsicológica envolvida nas relações entre conhecimento, valores, atitudes e ações. A cultura, os significados partilhados e o meio social permeiam as experiências individuais, construindo as referências com as quais ou em contraposição às quais as pessoas agem. O conhecimento é enraizado na vida social, expressando e estruturando a identidade e as condições sociais dos que dele partilham. Por isso, ações sociais ou educacionais que têm por objetivo criar condições de mudanças conceituais, de atitudes e práticas precisam estar engrenadas com o 
meio sociocultural no qual as pessoas, os profissionais, que serão abrangidos por essas ações vivem (Id. Ibid., p. 196-197).

A autora aponta, ainda, que as mudanças ocorridas e avaliadas por meio de pesquisa de opinião, aplicação de questionários, entrevistas e observações feitas com todos os envolvidos no curso, podem ser atribuídas ao entrelaçamento do programa com o meio no qual as pessoas a que ele se destina vivem. Os próprios tutores faziam parte da comunidade local e os materiais didáticos foram testados e reelaborados de acordo com aquela realidade escolar.

Também com a finalidade de discutir a formação de professores e criticar o tecnicismo presente nos modelos formativos atuais, Patto (2004) reflete sobre o lugar das humanidades neste processo de formação.

A autora afirma que as dificuldades da escola pública não podem ser compreendidas como de cada professor individualmente, maneira como são interpretados os obstáculos da educação e que está na base da constituição dos cursos de reciclagem e aperfeiçoamento, além dos de licenciatura e Pedagogia. A escola pública é uma instituição e, portanto, tem caráter social. Por isso, o que deve ser visado não é o professor individualmente, mas sim a escola.

O que não se percebe, segundo a autora, é que o chamado "despreparo" do professor só se agrava com propostas milagrosas dos cursos de aperfeiçoamento, porque continuam sendo apoiados em teorias psicológicas de desenvolvimento e de aprendizagem que entendem a relação professor-aluno abstraída do contexto educacional.

A concepção tecnicista de formação supõe que o ensino eficaz é aquele que aplica de forma competente um método pedagógico fundado em outros saberes, principalmente a psicologia do desenvolvimento e da aprendizagem.

Uma evidência da ênfase tecnicista, de acordo com a autora, é o espaço ocupado pela didática e pela psicologia nos cursos de formação. O predomínio destas matérias não proporciona ao professor a visão política e social da escola. É preciso, portanto, realizar uma mudança de mentalidade do próprio magistério e não uma mudança técnica do ensino. 
A crítica de Patto (2004) se refere ao fato de que a qualidade do ensino não será garantida pela mera substituição de uma teoria de desenvolvimento e de aprendizagem por outra. A escola é uma instituição social que contém aspectos filosóficos, históricos, sociais e políticos que precisam ser objeto de reflexão dos educadores.

Por isso, defende a presença da Filosofia e da História na formação de professores, para desenvolver tanto a atitude filosófica diante da realidade escolar, quanto para compreender a gênese histórica dos fenômenos educativos.

Discutindo o lugar da psicologia na formação dos professores, a autora aponta que, como instrumento para o entendimento do desenvolvimento e da aprendizagem para que o professor possa ter o domínio absoluto desses processos, ela é ilusória. O que a psicologia pode trazer é a "leitura” ou a "escuta” do que surge nos grupos de formação e o trabalho com a angústia presente nas relações educativas. Conclui que a:

Formação é mais do que domínio de conhecimentos em determinado campo disciplinar e aprendizagem de técnicas de ensino ou de pesquisa. Sem negar a relevância deles, insisto que formação é sobretudo exercício permanente de presença ativa no mundo, pensada da perspectiva do compromisso ético. Penso que uma nova concepção de formação docente deve começar com uma nova concepção de educador: seja alfabetizador no ensino fundamental, professor de matemática no ensino médio ou docente de história da educação no ensino superior, ele deve ser formado como trabalhador intelectual, pois só assim pode fazer a sua parte na realização histórica da humanização da vida (PATTO, 2004, p. 77, grifo da autora).

Os textos analisados mostram que a questão da formação docente e do lugar do conhecimento especializado nela tem sido entendidos em duas vertentes opostas: de um lado, trabalhos que representam a crença oficial de que os males da escola decorrem da má formação docente e que tentam saná-la com cursos centrados em conhecimentos específicos das ciências nas áreas auxiliares da educação; de outro, os que fazem crítica a esta crença. Entre estes, há os que criticam o tecnicismo, mas não o superam, e os que partem para outras concepções de formação, radicalmente diversas das que põem o 
ensino de técnicas e de conhecimentos instrumentais no centro do que chamam equivocadamente "formação".

A visão hegemônica, como dito anteriormente, quando se trata da formação docente, é a de que a melhora da escola pública deva ocorrer com a melhor capacitação do professor, que inclui conteúdos de psicologia. Por isso, além de estar presente em praticamente todos os cursos de licenciatura, mesmo que contemplada em apenas um semestre, a psicologia também se apresenta como conteúdo técnico a ser apropriado por educadores nos cursos de aperfeiçoamento e reciclagem promovidos pelas Secretarias de Educação em todo o país.

Todavia, pouco se sabe sobre a maneira como os professores se apropriam dos conteúdos de psicologia oferecidos ao longo de sua formação, e como avaliam seu processo formativo. Por isso, a investigação aqui proposta não pode limitar-se à análise dos currículos dos cursos de formação. É preciso ouvir os próprios professores sobre a presença da psicologia em sua preparação profissional.

A análise das reformas curriculares remete com freqüência a mudanças para outros conteúdos igualmente técnicos e não à crítica de uma psicologia que informa uma pedagogia de caráter tecnicista, tratando as dificuldades de escolarização de forma preconceituosa e patológica.

No contexto da crítica a uma psicologia essencialmente técnica, que informa o professor apenas sobre os processos cognitivos envolvidos na relação ensinoaprendizagem, esta pesquisa teve o objetivo geral de investigar como a psicologia está presente na formação e no trabalho pedagógico de professores a partir de sua própria análise e como objetivos específicos compreender a) a apropriação e a avaliação feitas pelo professor da psicologia que lhe foi ensinada ao longo de sua formação e b) as expectativas docentes em relação a esta área do conhecimento.

A finalidade última desta investigação foi refletir sobre a configuração atual da psicologia na formação de professores e sobre outras possibilidades de inserção desta área do conhecimento na preparação para o magistério que possam se comprometer com a transformação da educação escolar em vigor.

Passamos, então, no capítulo 2, à descrição da forma como a pesquisa foi realizada. No capítulo 3, apresentamos os professores depoentes e nos capítulos 4, 5 , 6 e 
7 faremos a análise de temas presentes nas entrevistas feitas com os educadores e que se mostraram relevantes à pergunta que motivou esta pesquisa. O capítulo final é dedicado à discussão do que foi encontrado nos depoimentos e, especialmente, do papel da psicologia na formação para o magistério. 


\section{CAPÍTULO II - A PESQUISA}

\subsection{Escolha do local de pesquisa}

A escolha da escola ocorreu a partir de contato com a equipe de psicólogos do Serviço de Psicologia da Universidade de São Paulo, que vem desenvolvendo há alguns anos um trabalho junto às escolas municipais da Zona Oeste da cidade de São Paulo. Fomos orientados a entrar em contato com os supervisores de ensino que coordenam as instituições educativas desta região. Uma reunião foi realizada com os supervisores para apresentar o projeto de pesquisa e levantar o interesse das escolas abrangidas por esta coordenadoria em participar do trabalho. Decidiu-se que o projeto seria apresentado a todas as instituições de ensino a ela vinculadas, desde a educação infantil até o ensino médio $^{16}$. Não se teve controle nem acesso à maneira como o projeto foi apresentado em cada escola. O retorno recebido, por meio dos supervisores de ensino, foi o de que apenas uma escola manifestou interesse e é nela que o trabalho foi realizado.

\subsection{Escolha dos participantes da pesquisa}

\subsubsection{Contato inicial com os docentes}

Uma reunião foi realizada na escola com todos os docentes participantes da Jornada Especial Integral (JEI) ${ }^{17}$ no período das $17 \mathrm{~h}$ às $19 \mathrm{~h}$, incluindo os professores do ensino fundamental I (primeira a quarta séries, do período vespertino) e os da Educação de Jovens e Adultos, que ocorre no período noturno ${ }^{18}$. A finalidade foi apresentar, de

\footnotetext{
${ }^{16}$ Várias cópias do projeto de pesquisa foram enviadas à coordenadoria, que as distribuiu às escolas a ela vinculadas.

${ }^{17}$ Este é o espaço destinado aos trabalhos pedagógicos na instituição. Existem desde reuniões coletivas, nas quais realizamos os primeiros encontros grupais, até os momentos de trabalho individual, nos quais, geralmente, ocorreram as entrevistas.

${ }^{18}$ Os docentes do período matutino, que lecionam para o ensino fundamental II (quinta a oitava séries), não foram contemplados, uma vez que realizam JEI em outro horário e a sugestão da direção e da coordenação pedagógica da escola foi a de que trabalhássemos no período já mencionado, porque os
} 
forma detalhada, o projeto de pesquisa e esclarecer possíveis dúvidas, bem como verificar o interesse do grupo em participar, uma vez que não havia existido, até este momento, contato direto com a escola. Na reunião, estabeleceu-se um cronograma para a realização de encontros grupais com os educadores, que visavam discutir o projeto de pesquisa, estabelecer vínculos de confiança entre o pesquisador e os docentes e compreender um pouco da história da escola naqueles aspectos que o grupo julgasse importantes, tarefa esta proposta pelo próprio grupo.

\subsubsection{Escolha dos participantes da etapa de entrevistas}

Todos os professores que participaram das reuniões grupais foram convidados a dar seus depoimentos na etapa de entrevistas. De um total de aproximadamente vinte e cinco professores, sete participaram das entrevistas ${ }^{19}$. No interior da epistemologia que orienta a pesquisa, o critério de representatividade estatística não foi, portanto, utilizado na escolha dos sujeitos ${ }^{20}$. Assim, o depoimento dos sete professores permitirá compreender tanto a formação em psicologia destes docentes em particular, como dos educadores da rede pública, em geral.

\subsection{As entrevistas}

As entrevistas foram realizadas pressupondo-se que os professores são interlocutores, depoentes, co-participantes na construção do conhecimento.

\footnotetext{
docentes do período matutino não manifestaram interesse em participar do projeto. Além disso, o horário das $17 \mathrm{~h}$ às $19 \mathrm{~h}$ foi o momento disponibilizado pela escola para a realização do trabalho.

${ }^{19} \mathrm{O}$ número total de reuniões grupais foi sete. O número de participantes presentes nessas reuniões variou de treze a vinte e cinco, uma vez que a presença do pesquisador se dava durante seu horário obrigatório de trabalho pedagógico coletivo.

${ }^{20}$ Ginzburg (1987) pesquisou um único indivíduo como representante de um período histórico e de uma classe social para investigar as relações entre cultura popular e cultura erudita na Idade Média. A partir de documentos disponíveis sobre o processo sofrido por um moleiro durante a Inquisição e de informações sobre o que ele leu, além de seus depoimentos, o autor analisa como o moleiro articulou linguagens que estavam historicamente à sua disposição. O historiador mostra em seu estudo como um indivíduo pode ser pesquisado como microcosmo de um estrato social num determinado período histórico, pois o universal está contido no particular, até mesmo nos casos atípicos, como o deste moleiro herege.
} 
Thiollent (1981) ressalta a importância de o entrevistador ser um pesquisador, não um mero aplicador de questões pré-estabelecidas. As questões fechadas de um roteiro padrão ocasionam não só a pobreza das respostas, como a indução da resposta pela pergunta.

Numa perspectiva diretiva de entrevista, segundo o autor, os entrevistadores passam a ser executores passivos das instruções de um questionário, desprovidos de qualquer iniciativa intelectual:

Nesta concepção de entrevista, os entrevistadores são intermediários, subalternos, intertrocáveis e submetidos ao controle dos administradores de pesquisa que aplicam normas burocráticas. Tal padronização é considerada, no referencial positivista, como requisito de comparabilidade e de confiabilidade das respostas e, logo, base necessária da quantificação. Ora, o que a pesquisa ganha com isto tem contrapartida: a pobreza dos resultados ou o fechamento do discurso, antes de tê-lo aberto (THIOLLENT, 1981, p. 80).

Isto não significa que a entrevista não-diretiva tenha como base o senso comum. Trata-se da flexibilização do relacionamento pesquisador/pesquisado, tentando reduzir os efeitos da imposição da problemática do estudo. A entrevista não-diretiva também sofre críticas, de acordo com o autor, pois não elimina a distância entre o entrevistador e o entrevistado:

A desigualdade é inerente a uma situação de comunicação sobre a qual o respondedor não tem controle e permanece separado da interpretação e da utilização social da informação transmitida. Em situação como esta, a não-diretividade dissimula, sob máscara de reciprocidade e de liberdade de fala, a hierarquia e a monopolização do saber (aspecto institucional) (Id. Ibid, p. 83).

A entrevista não-diretiva, todavia, não propõe uma completa estrutura do campo de investigação, como as entrevistas diretivas, mas possibilita ao entrevistado explorar 
melhor a problemática em questão. Este tipo de entrevista favorece a captação de uma informação mais profunda; facilita, ainda, a produção de significações carregadas de afetividade, o que permite a abertura do discurso, ao invés de fechá-lo.

Rodrigues (1978) ressalta a importância de garantir, pelo método, a produção de depoimentos para além da coleta de dados por meio de um questionário:

[...] dado o objeto de estudo que escolhemos, e os pressupostos teóricos que adotamos, havíamos abdicado, desde logo, a qualquer pretensão quantitativa. O tipo de fenômeno que nos propúnhamos conhecer devia ser alcançado pelas técnicas possíveis e não pelas consideradas ideais. Corríamos claramente o risco de ganhar em rigor e perder o objeto, se nos prendêssemos aos procedimentos mais correntes em pesquisa social (Id. Ibid., p. 31).

Os questionários ou as entrevistas com questões fechadas, segundo a autora, pecam por colocar ao depoente questões que talvez ele não se colocasse. Destaca a importância de perguntas norteadoras sobre o tema de investigação no aprofundamento dos depoimentos, o que faz do processo de produção do conhecimento sobre o objeto de estudo uma parceria entre os interlocutores. A entrevista em profundidade, com questões abertas, possibilita a:

[...] compreensão de como o indivíduo elabora dentro de si mesmo sua realidade objetiva, qual sua visão de si mesmo e do mundo, que tipo de percepções e explicações utiliza na sua tarefa de dar um sentido ao mundo que o rodeia, nos seus próprios termos (Id. Ibid., p. 25).

A partir da proposta de Rodrigues (1978), as entrevistas compreenderam os seguintes momentos:

\subsubsection{Conversa inicial não gravada}

A conversa inicial não gravada foi feita com cada professor que se dispôs a participar da etapa de entrevistas, após a realização das reuniões grupais. Não houve 
duração prevista para esta etapa, que podia requerer mais de um encontro. Este momento teve como objetivo esclarecer a proposta individualmente, discutir possíveis dúvidas e trabalhar o vínculo de confiança com cada depoente. Foram incluídos, neste momento, temas referentes à história do depoente como professor, sua prática profissional e sua formação, abordados de modo informal.

2.3.2 Entrevista gravada semi-dirigida sobre a formação profissional do docente

Neste segundo momento, que não continha um número de encontros préestabelecidos, podendo variar para cada depoente, foi registrada a fala do entrevistado sobre suas experiências pedagógicas e sua formação em psicologia. Trata-se de um relato autobiográfico sobre o caminho percorrido pelo professor na sua formação em geral, e em psicologia, em particular. $\mathrm{O}$ entrevistador fez apenas uma fala inicial e o relato foi livre. As intervenções do entrevistador tiveram por objetivo apenas estimular o depoente a continuar falando.

Os temas norteadores do entrevistador foram: Como a psicologia se configura na formação do professor e $O$ espaço real por ela ocupado no trabalho docente e o espaço esperado pelo depoente.

O primeiro tema pode ser subdivido em: a) O que é psicologia para o depoente?; b) Qual a história de seu contato com a psicologia? (estimulando o professor a falar desde os primeiros contatos com esta matéria, por meio de textos, livros, autores, estudos, aulas, até os cursos de reciclagem/aperfeiçoamento atuais); c) O que restou deste contato ou desta psicologia em seu trabalho pedagógico?; d) Como a psicologia está, de fato, presente na formação do depoente, a partir do relato de situações concretas nas quais utiliza os conhecimentos desta área?

Quanto ao segundo tema, a indagação que norteou a entrevista foi: Quais são as expectativas do entrevistado com relação à psicologia ou no que a psicologia poderia, a seu ver, contribuir para o seu trabalho pedagógico? 
Um terceiro momento, também gravado, centrou-se em aspectos pouco claros do depoimento e contemplou perguntas que podiam esclarecer pontos obscuros ou não mencionados anteriormente.

\subsubsection{Discussão do depoimento com o entrevistado}

Foi entregue a cada um dos entrevistados a transcrição das etapas de entrevista gravadas, para que ele pudesse discutir com o entrevistador aspectos que julgasse relevantes e também modificar seu depoimento, caso desejasse, a partir das discussões realizadas. Este encontro também foi gravado ${ }^{21}$.

\subsection{Análise das entrevistas}

A análise dos depoimentos compreendeu algumas etapas: a princípio, realizou-se uma leitura para organizar o material obtido. Foi um período de intuições, que teve por objetivo tornar operacionais e sistematizar as idéias iniciais; tratou-se da fase de escolha do que seria submetido à análise; de formulação de hipóteses que fundamentassem a interpretação final. Esta leitura é o primeiro contato do pesquisador com o texto que será analisado. Permite conhecê-lo, deixando-se invadir por impressões e orientações. A leitura vai se tornando mais precisa em função das hipóteses emergentes.

A partir da leitura inicial, alguns temas gerais para análise foram surgindo e algumas hipóteses de interpretação foram levantadas. Uma leitura mais minuciosa permitiu precisar os temas de análise que se mostraram presentes em todos os depoimentos, em suas várias etapas. São eles:

1. A relação do depoente com a psicologia, que compreende a) uma definição de psicologia, b) como ela está presente em seu trabalho pedagógico, c) quais as demandas/expectativas do professor para esta área do conhecimento e d) qual a história do contato com psicólogos;

\footnotetext{
${ }^{21}$ Apenas uma professora fez alterações em seu depoimento que, em geral, se referiram a pequenas mudanças para a melhor compreensão do leitor.
} 
2. A psicologia na formação docente, que permitiu apreender também a formação em geral;

3. A relação estabelecida pelos depoentes entre teoria e prática e

4. A realidade escolar atual. 


\section{CAPÍTULO III - OS DEPOENTES ${ }^{22}$}

\section{Antônio Carlos}

Antônio Carlos é o único homem que participou da pesquisa. É professor do laboratório de informática da escola. Foi também quem o organizou da forma como se configura atualmente. Tem quarenta e dois anos e quinze de magistério.

Antes de trabalhar como docente, foi funcionário de um banco, pois é formado em Engenharia e Matemática. Iniciou sua carreira como professor em um curso de alfabetização de jovens e adultos. Para tanto, fez, durante um ano, aos sábados, um curso de preparação pedagógica, tendo, nesse momento, um contato superficial com a psicologia. De 1985 a 1991 alfabetizou adultos. Depois disso, começou a atuar na implantação de laboratórios de informática nas escolas públicas municipais da cidade de São Paulo. A partir de 1995 retornou à sala de aula, mas como professor de informática. É ele quem organiza, junto com os outros docentes da escola, os conteúdos escolares que serão ensinados com o auxílio do computador.

O depoente trabalha três períodos por dia. De manhã, dá aulas numa escola de informática; à tarde e à noite, ministra aulas para alunos da quinta a oitava séries do ensino fundamental II e também na $\mathrm{EJA}^{23}$, no laboratório de informática da escola onde a pesquisa foi realizada.

Ao longo de nossos três depoimentos falou bastante, principalmente sobre a inclusão dos alunos com necessidades especiais. Fez denúncias. Sente-se feliz com a docência, embora se queixe constantemente das condições de trabalho que o impedem de exercer sua função da maneira como gostaria.

Mostrava-se satisfeito em poder participar das entrevistas, apesar do pouco tempo de que dispunha. São notáveis seu empenho e comprometimento com a escola e com os alunos. Acredita que a máquina - como chama o computador - deve ser apenas

\footnotetext{
${ }^{22}$ Os nomes dos depoentes foram mantidos, com sua autorização, com exceção de um deles que é fictício, a pedido da professora.

${ }^{23}$ Educação de Jovens e Adultos.
} 
um recurso para facilitar a aprendizagem dos conteúdos escolares relevantes para a formação dos alunos.

\section{Carla}

Carla é a mais jovem de todos os depoentes. Tem vinte e sete anos e oito de magistério. Quando iniciamos o trabalho, tinha sido transferida para essa escola. Era nova no grupo, que a acolheu com certo receio.

Cursou o magistério no $\mathrm{CEFAM}^{24}$ e, na época de nossas entrevistas, concluía o curso de Pedagogia em uma faculdade particular. É casada e freqüenta uma igreja evangélica. Faz questão de mostrar como a religião está presente em sua vida docente.

$\mathrm{Na}$ época das entrevistas, dava aulas para a segunda-série do ensino fundamental I, mas estava procurando uma outra classe para lecionar em outra escola, pois precisaria trabalhar em período integral, uma vez que o marido estava desempregado.

Desde criança queria ser professora como seu pai. Cursou o CEFAM com bolsa de estudos e quando já dava aulas, conseguiu pagar seu curso superior. Considera-se feliz com a profissão e com a escola na qual trabalha atualmente. Já deu aulas em escolas muito próximas a favelas e sofreu inúmeras situações de violência. Queria ser removida.

Realizamos três encontros, sempre com pouco tempo. Quando entreguei a transcrição de seu depoimento, fez questão de ler e corrigir falas que ficaram incompreensíveis. Acrescentou, ainda, trechos que poderiam esclarecer suas opiniões.

\section{Márcia $^{25}$}

Márcia é considerada uma boa professora por seus colegas e pela coordenação da escola. É calma e bastante carinhosa com seus alunos da primeira-série do ensino fundamental I. Gosta de manter a classe sempre muito organizada e passa somente as lições que dará conta de corrigir. Na época das entrevistas, sentia-se muito angustiada

\footnotetext{
${ }^{24}$ Centro de Formação e Aperfeiçoamento no Magistério.

${ }^{25}$ Nome fictício, a pedido da professora.
} 
por ter uma aluna com síndrome de Down em sua sala e não possuir conhecimentos sobre o assunto. Por isso, foi procurar ajuda na $\mathrm{APAE}^{26}$. Nessa escola já teve alunos com todos os tipos de deficiência.

Apesar de ter desejado cursar Psicologia, iniciou, aos dezessete anos, a faculdade de Pedagogia na USP ${ }^{27}$. Tinha medo de não passar no vestibular e o curso de Psicologia, por ser integral, a impediria de trabalhar. Tem trinta e quatro anos e quinze de magistério. É casada e tem uma filha.

Formou-se, também, como psicopedagoga no Instituto Sedes Sapientiae, em São Paulo. Queria adquirir novos conhecimentos e não se preocupava “apenas com o diploma”.

Durante nove anos trabalhou com alfabetização em escolas particulares com turmas da pré-escola. Nelas, tinha, em média, seis alunos por sala. Conseguia alfabetizar todos eles. Na escola pública, sente-se frustrada porque, a cada ano, aproximadamente um terço de seus alunos não se alfabetiza.

Márcia mostrou-se sempre muito comprometida e organizada com os afazeres docentes. Adora o trabalho de alfabetização. Tem uma preocupação constante em corrigir as lições que passa aos alunos e de não deixar de atendê-los individualmente. Para isso, sempre realizou muito trabalho fora da escola. Atualmente, considera que precisa trabalhar menos em casa e por isso, tem tentado dar aos alunos apenas as atividades que conseguirá corrigir na escola.

Ao longo de nossos quatro encontros, mostrou-se sempre muito disponível e dedicada. Já havia participado de outra pesquisa de pós-graduação na qual a pesquisadora freqüentava suas aulas. Sempre exigiu retorno sobre as observações realizadas.

\section{Maristela}

Maristela foi a depoente mais difícil de conquistar. Desde os primeiros encontros grupais mostrou-se desconfiada e fazia inúmeras perguntas com o intuito de testar-me.

\footnotetext{
${ }^{26}$ Associação de Pais e Amigos dos Excepcionais.

${ }^{27}$ Universidade de São Paulo.
} 
Questionava todas as propostas. Aos poucos, foi se aproximando e tornou-se uma depoente ativa, que queria “deixar o seu recado”. Quando me dispus a ouvi-la, nosso relacionamento se transformou. Parece ser a mais politizada de todos os depoentes, provavelmente, em virtude de sua formação e por ter trabalhado durante muitos anos em sindicatos.

Tem quarenta e um anos e quinze de magistério. Atualmente, dá aulas de História no período noturno no ensino de jovens e adultos. É formada em História, Geografia e Ciência Política. Pretende ainda cursar Filosofia. Estudou psicologia em apenas uma disciplina durante a graduação.

Nos depoimentos falava sobre as dificuldades em relacionar-se com seus colegas e de como a psicologia poderia contribuir com os relacionamentos humanos. Além disso, questionava preconceitos, principalmente contra os pobres e não se conformava com explicações simplistas. Queria aprofundar-se. Ao todo, realizamos quatro encontros e sempre terminávamos as entrevistas um pouco antes do início de suas aulas, pois ela não queria se atrasar.

Maristela sempre chamou a minha atenção pelo comprometimento que tem com o magistério. Deseja “fazer diferença” na vida de seus alunos.

\section{Nancy}

Nancy fala pouco e baixo, aparenta muita tranqüilidade e cansaço. Tem cinqüenta e seis anos e trinta de magistério. É formada em Pedagogia e fez um curso de especialização em Psicopedagogia. Gosta de lecionar para as terceiras e quartas séries do ensino fundamental I. Já foi coordenadora pedagógica, função na qual se aposentou. Mas decidiu continuar a trabalhar, prestou novo concurso e voltou a dar aulas.

Aos dezesseis anos, já dava aulas particulares, organizando uma turma em sua casa. Sempre quis cursar Psicologia, mas achava que não passaria no vestibular. Mas, quando tem contato com textos sobre o assunto, lê por conta própria. Geralmente são livros de auto-ajuda, denominados por ela como “psicologia”. 
A primeira impressão que tive de Nancy foi de uma pessoa triste e sofrida. Em nossas conversas, ao contrário, mostrou-se muito feliz com seu trabalho. Gosta de planejar e dar suas aulas.

Ao todo, realizamos três encontros. Tinha sempre a preocupação de que a pesquisa deveria trazer algum retorno para a escola. Porém, mesmo que isso não ocorresse, gostaria de participar, pois sabia da resistência de muitos de seus colegas.

\section{Sandra}

Sandra, juntamente com Wanda, foi uma das primeiras que aceitou participar das entrevistas. A princípio, tinha como motivação a possibilidade de discutir os problemas de sua sala de aula com uma psicóloga, pois na época, lecionava para uma terceira-série “projeto ${ }^{28 ”}$. Todavia, desejava me ajudar. Sabia que muitos de seus colegas não queriam participar do trabalho e, por isso, também, resolveu dar seu depoimento. Tinha realizado um trabalho de conclusão de um curso de aperfeiçoamento no qual precisou entrevistar pais de alunos e afirmava saber das dificuldades para encontrar pessoas disponíveis a gravar uma entrevista.

Apesar de conversarmos sempre às sextas-feiras, após suas aulas, mostrava-se atenciosa e interessada no trabalho. Tinha confiança em mim e sempre acreditou que eu não faltaria aos encontros marcados. Ao todo, realizamos seis encontros. Como a gravação de um deles foi perdida, dispôs-se a falar novamente sobre o que havíamos conversado.

Sandra é casada, tem duas filhas e é evangélica. Tem quarenta e cinco anos, dos quais dedicou os últimos quatorze ao magistério. Anteriormente, desenvolvia atividades em um escritório de contabilidade, pois fez um curso técnico nessa área. Sempre quis ser professora. Concluiu o magistério em 1988 e participou do $\mathrm{PEC}^{29}$ durante os anos de 2003 e 2004, cursos nos quais teve contato com conteúdos de psicologia.

Em nossos encontros falava sobre seus problemas pessoais, relatava a angústia por não conseguir alfabetizar seus alunos, mostrava os materiais com que trabalhava.

\footnotetext{
28 As salas-projeto vieram substituir as salas especiais, mas basicamente possuem as mesmas características e funções.

${ }^{29}$ Programa de Educação Continuada, oferecido pela prefeitura da cidade de São Paulo, em parceria com a Universidade de São Paulo (USP).
} 
Em seus depoimentos, dizia sempre que era uma pessoa muito esquecida, desorganizada e indisciplinada e, por isso, tinha dificuldades de lembrar-se dos conteúdos estudados em sua formação, atribuindo culpa a sua memória que estava fraca e talvez à idade. Apesar disso, denunciava com precisão a formação precária que teve contato.

Sandra sempre esteve muito próxima a mim. Mostrava-se feliz quando eu chegava em sua sala, após o horário da aula, para conversarmos. Estava sempre me esperando. É muito simpática e bem quista por seus colegas de trabalho. Aparenta cansaço e frustração por não dar conta de ensinar a seus alunos os conteúdos que deveriam aprender. É imbuída dos tradicionais preconceitos que explicam o fracasso escolar. Sente-se desanimada com o trabalho docente, pois não sabe mais o que fazer para ensinar seus alunos.

\section{Wanda}

Wanda foi a primeira professora que se disponibilizou a participar das entrevistas. Desde nossos encontros grupais, mostrou-se muito receptiva e atenciosa. Realizamos quatro encontros, nos quais sempre falou bastante, sendo interrompida apenas pelo horário de início de suas aulas. Demonstrava gostar de nossas entrevistas, pois as considerava como momentos em que podia falar sobre suas dificuldades, inclusive pessoais.

A depoente é divorciada e reside com sua mãe, filha, neta e genro, os quais têm a responsabilidade quase total de manter financeiramente.

Fez o antigo Curso Normal e formou-se em Letras, apesar de ter desejado cursar Medicina. Nesses dois cursos teve contato com conteúdos de psicologia. Tem cinqüenta e três anos e vinte e cinco de magistério. Lecionou durante dezesseis anos para a primeira-série do ensino fundamental I e considera-se uma boa alfabetizadora. Há oito anos dá aulas na Educação de Jovens e Adultos (EJA) para as três primeiras séries do ensino fundamental I. Quando mudou para a EJA, sentiu medo em lidar com alunos adultos. Mas foi se acostumando e, atualmente, sente-se muito satisfeita porque os considera muito carinhosos e perseverantes. 
Sente-se frustrada porque atingiu o grau máximo em sua carreira docente e não tem mais como avançar, o que significa, também, a impossibilidade de aumento de salário. Não tem vontade de parar de lecionar, apesar de já estar bem próxima da aposentadoria.

Apresenta-se como uma mulher jovem, embora se queixe com freqüência de sua depressão e outros problemas de saúde que a impedem de lecionar, sendo afastada constantemente por motivos de doença.

Com relação ao trabalho que realizamos, sempre teve a expectativa de poder ter momentos para falar sobre si e considera que sou uma psicóloga diferente das que conheceu, porque além de escutar, eu falo um pouco mais.

Wanda impressionou-me pela atenção despendida ao trabalho e por vincular-se tão facilmente a mim. 


\section{CAPÍTULO IV - $\quad$ A RELAÇÃO COM A PSICOLOGIA: o pedido de socorro}

Tem hora que fica todo mundo como barata tonta. No final da história é tanta barata tonta que nos esbarramos. Não sei, talvez o psicólogo na escola desse conta de ajudar a gente a dirimir um pouco essa angústia [Maristela].

As formas como os entrevistados concebem a psicologia aparecem em vários aspectos de suas falas: quando a definem; quando falam da presença dela em seu trabalho docente; quando revelam suas expectativas para esta área de conhecimento; quando relatam suas experiências com profissionais psicólogos.

No que se refere às definições de psicologia, alguns a definem pelo objeto de estudo - como o comportamento, a mente, ou a consciência; outros, a partir de sua função, daquilo que ela produz. Os que se aproximam do objeto de estudo da psicologia afirmam:

É do senso comum mesmo, é aquela origem etimológica da palavra, psique, da mente humana. Porque quando eu falo em mente humana, na verdade eu quero dizer uma coisa mais ligada à consciência [Maristela].

Psicologia pra mim é um ramo de estudo que enfatiza a mente [Carla].

Psicologia é o estudo, se eu fosse definir, pra mim, o estudo do comportamento humano, tudo que tem a ver com o comportamento. Mas tem várias coisas que eu estudei que eu até nem sei se fazem parte da psicologia ou não, mas eu considero também. Por exemplo: linguagem corporal, técnicas corporais, eu acho que tem a ver, não é? É uma linguagem do corpo, eu acho que você acaba demonstrando muita coisa que você está sentindo, muita coisa que você não sabe o que significa, com a linguagem 
corporal. Não sei se faz parte ou não, mas na minha cabeça isso está tudo interligado [Márcia].

É uma ciência que estuda o comportamento humano, se preocupa com as relações entre as pessoas [Sandra].

Psicologia é uma matéria, um estudo, uma ciência que estuda o comportamento humano. $O$ que está acontecendo de errado, tenta solucionar. É o porquê de muitas coisas na vida. Eu acho que ela tenta ajudar. Eu acho que ela está sempre andando junto pra melhorar a vida de uma pessoa, de uma criança, na parte psicológica mesmo, cerebral. Penso assim [Wanda].

Outras definições tratam também da aplicação prática da psicologia, mostrando como ela poderia contribuir para melhorar o relacionamento das pessoas:

Eu vou ser bem simplista, eu acho que primeiro, não sei se é errado, acho que a psicologia tenta trabalhar o relacionamento humano entre as pessoas. Eu acho que é isso. A gente tem conflitos, às vezes, ou de comunicação, ou de convívio com as pessoas, e eu acho que a psicologia, no meu entender bem simplista - porque eu não sou dessa área - é pra tentar facilitar o relacionamento entre as pessoas. Até na área pedagógica, eu acho que a gente tem conflitos na sala de aula, que, às vezes, a gente não está preparado. Algumas coisas que eu acho que são muito na relação intrapessoal, interpessoal, que as coisas acontecem. Eu acho que hoje na escola o grande problema é isso, da relação entre professor e aluno. Tem alguns problemas e tem também, é lógico, a gente sabe, que tem alguns distúrbios que não sei como que eu classifico esses distúrbios, mas que, às vezes, está ligado à pessoa mesmo, a uma constituição psicológica que aí eu não sei. Mas eu, o seguinte, a princípio, pra mim, eu viria assim, na minha visão, é pra facilitar o relacionamento, o meu relacionamento, entender melhor as pessoas e me fazer entender também para elas [Antônio Carlos].

Psicologia faz parte da minha vida, eu acho super importante, porque trata de relacionamentos humanos, no meu modo de entender. Eu acho que a base da vida são os relacionamentos humanos. Se as pessoas se entendem, se elas se dão bem, se elas conseguem resolver mais ou menos os seus problemas, elas não ficam descontando nos 
outros as suas dificuldades, seus problemas, elas vão se entender melhor e poder entender os outros também [Nancy].

A psicologia, além disso, auxiliaria a compreender e a explicar os problemas de aprendizagem dos alunos:

Uma coisa que agora me veio, seria por que a criança não aprende, por exemplo. Isso seria um fator que talvez a psicologia pudesse explicar. Porque, às vezes, a gente tem alunos que eles não conseguem ser alfabetizados. Que bloqueio é esse? O que está acontecendo dentro da cabeça dela? Eu não sei se aí entra a psicologia de aprendizagem, não sei se é isso, ou seria uma psicologia de modo geral, a criança precisa fazer uma terapia, ou ela precisa tomar algum remédio na psiquiatria - seria o ramo - não sei. Mas isso é algum bloqueio que a gente sente - isso pelo menos eu sinto - quando a gente está alfabetizando, quando a gente está explicando, ou mesmo na Matemática, no raciocínio lógico. A criança não consegue entender, ela não consegue aprender, por mais concretização que você faça, ela tem parece que um bloqueio. Eu falei assim: "Meu Deus! Tem alguma coisa que está bloqueando essa criança”. Que a gente precisaria ir mais a fundo, mas como a gente não é psicólogo, você não sabe como ir além [Nancy].

As definições de psicologia estão presentes nos depoimentos principalmente quando os professores relatam a maneira como conduzem seu trabalho pedagógico, guiado por conhecimentos por eles considerados psicológicos. Nesta descrição, utilizam termos da psicologia para explicar e intervir em situações de não aprendizagem, mostram como teorias podem orientar sua prática, aproximando-as do senso comum. Esta aproximação entre ciência e senso comum permite que todos se considerem, em alguma medida, psicólogos.

Antônio Carlos explica como trabalha com uma aluna portadora de síndrome de Down:

Tenho a M. [uma aluna com síndrome de Down], não sei se você conhece a $M$. da primeira-série, uma menina que eu tento trabalhar, de me aproximar com ela, conversar, ela se apega muito facilmente às pessoas, então é uma criança muito 
dependente, e que eu tento usar da minha facilidade que eu tenho, usando a minha didática e me aproximar daquela criança, mas eu faço isso espontaneamente, sem usar nenhuma teoria.

Posteriormente, quando indagado sobre quais dificuldades encontra no trabalho com essa aluna, o professor responde:

Ah, de tentar entender mesmo como é que acontecem as coisas na cabecinha dela. Eu tento me pôr em cada comportamento que ela tem, eu tento me pôr no lugar dela pra saber o que ela faria, o que eu faria se tivesse no lugar, eu tento entender, eu tento pensar como é que ela age, as manifestações que ela tem. $\mathbf{E}$ eu tento ser o mais carinhoso possível, eu tento usar de artifícios, mas não tem nada muito trabalhado, entendeu? A gente também não faz nenhuma abordagem se utilizando da psicologia pra trabalhar com ela. Quer dizer, eu nem sei se, de repente, eu estou fazendo algo vinculado à psicologia, até pode estar. Porque eu faço um trabalho diferenciado mesmo, eu falo em sentar do ladinho dela, de tentar perceber o que ela é capaz de fazer, o que ela quer fazer, o que ela se sente estimulada a fazer, entendeu? Mas não dá tempo pra eu depurar assim, fazer uma avaliação e tentar produzir alguma coisa mesmo pensada, não dá.

O depoente enfatiza que seu trabalho não é orientado por concepções de psicologia, mesmo que ressalve a possibilidade de utilizar recursos de maneira não intencional. Os trechos destacados mostram como explicações psicológicas estão presentes na fala do docente para "tentar entender o que acontece na cabecinha da criança”, além de ações consideradas pelos professores como pertencentes ao psicólogo, como o trabalho individualizado e diferenciado com aqueles alunos que não aprendem. Continuando, Antônio Carlos utiliza expressões comumente atribuídas ao campo semântico da psicologia para explicar o fracasso escolar dos alunos adultos:

E, aliás, o adulto ele vem com um monte de frustrações, ele já vem pra escola à noite, ele já vem com uma baixa-estima: “Ah, eu já sou um fracassado...”, então a gente tenta primeiro resgatar o valor, resgatar ele de novo, o valor, a auto-estima dele [...] $\mathrm{Na}$ alfabetização de adultos, eu acho que o professor que está em sala de aula com 
alfabetização de adultos, o aluno adulto ele tem mais barreiras do que a criança, porque tem essa coisa aí, esse lado da psicologia, que pra ele, ele tem essa frustração, esse sentimento de fracasso, de não ter podido estudar, e estar voltando e tem uma baixa-estima, ele tem sempre o discurso: "Ah, isso eu não vou aprender, se eu não aprendi até agora, não vou aprender mais”, entendeu? Então a gente tem que usar de meios pra gente estar resgatando, pôr a auto-estima dele de novo no lugar, pra estimular ele estar produzindo. A motivar o tempo que ele está na escola. Porque se deixar, o aluno, eu sinto isso, que ele tem muito da desmotivação. E que a gente tem que trabalhar e isso que é forte, essa coisa da desmotivação.

O mesmo ocorre no depoimento de Carla, no qual a professora utiliza a psicologia para classificar e explicar o comportamento de uma criança:

Porque não adianta você ter raiva da criança hiperativa porque ela não pára um minuto. Se você compreende o problema dela, você trata diferente e você começa a entender que a hiperatividade requer cuidados diferentes de qualquer outra criança e que ela precisa ter uma atividade mais motivadora, ela precisa estar fazendo constantemente alguma coisa e que aquilo lá não é pra te irritar. Ela não consegue controlar aquilo.

A mesma professora dá um exemplo de como a psicologia, por meio do discurso do construtivismo, norteia as ações dos professores:

Eu estudei e eu aprendi que a criança tem que aprender a aprender, tem que aprender a buscar o conhecimento, e eu estou lá como uma facilitadora desse conhecimento. Então quando eu começo a cumprir o currículo escolar, eles sabem que a responsabilidade é deles, e isso vem um pouco do meu estudo de psicologia, esse tipo de postura de ensinar a criança.

Já Nancy, quando indagada sobre a presença da psicologia em suas aulas, aponta uma característica pessoal - o fato de ser muito observadora - como atributo adquirido por meio de estudos desta ciência: 
Muito, muito [utiliza muito a psicologia], não só na minha aula como na minha vida. Em relação aos meus filhos, em relação às pessoas. Porque eu gosto muito de analisar. Uma vez nós fizemos uma dinâmica e as professoras, uma tinha que falar da outra e aí falaram: "Você é muito observadora, muito observadora". E eu acho que eu sou mesmo, porque eu observo muito as pessoas, a postura delas, o jeito delas, a maneira delas falarem, a maneira delas não falarem, o olhar delas. Eu acho, não sei se é um componente meu já de caráter ou a psicologia ajudou. Acho que a psicologia também ajudou porque como eu gosto de estudar relações humanas a gente vai incorporando aquilo que lê. Que eu acho fundamental, porque eu acho que teoria só por teoria não leva a nada. Eu acho que você tem que complementar na tua vida pra se tornar uma pessoa melhor. E eu acho que dá pra ter uma postura melhor diante da vida, saber se relacionar melhor com as pessoas, não sei se sei me relacionar bem com as pessoas, não sei o que as pessoas acham de mim. Às vezes, tem gente que me acha fechada $e$ então eu procuro sempre melhorar. Quando alguém faz uma crítica, alguma coisa, na hora a gente fica meio balançada, mas depois eu fico pensando naquilo. Porque ninguém fala nada à toa. Aí eu fico pensando naquilo: "Será que sou assim mesmo?”. Aí eu começo me analisar, e ver os pontos onde que eu tento melhorar. Não sei, acho que na vida a gente sempre tem que tentar melhorar. Então eu acho que a psicologia me ajudou como ser humano.

No relato acima, percebe-se a aproximação da psicologia com o senso comum. Daí, a considerar-se psicóloga, é apenas um passo. Nancy tenta diagnosticar as causas dos comportamentos de seus alunos:

Olha, o que eu mais uso é aquilo que falam de mim, que eu sou observadora. Então eu fico observando, porque eu acho que, além de ser professora, a gente tem que ser educadora, e nos tempos de hoje a gente é muito educadora, porque infelizmente há um déficit mesmo de encaminhamento das crianças em casa, sabe? A educação em casa, o olhar da mãe em casa pra criança, atenção. Porque eu sou de uma época anterior. Nessa época, eu comecei na prefeitura em 1971, e eu sentia que as crianças eram diferentes, é lógico que tem toda uma evolução, mas eu sentia a mãe mais presente, a mãe mais atenta, mais carinhosa, então a criança era diferente. Hoje não, hoje eu percebo que a criança é muito agressiva, ela fala muito alto porque eu acho que em casa ela não deve ser ouvida, então ela tem que quase gritar pra ser ouvida. Então eu 
fico pensando - porque a gente não pode interferir dento da casa da criança - e que é o que eu falo pra eles: “Aqui eu olho vocês, eu pego vocês, eu tento analisar vocês da melhor maneira que eu puder, mas eu não sei o que acontece dentro da casa de vocês” - mas dá pra perceber o que eles trazem de casa pra escola. A criança que fica mais atendida, ou que tem uma educação mais formalizada em casa, e aquela que tem muitas dificuldades, de normas, de comportamento ou que a gente levantou e tudo. Mas a psicologia me ajudou nisso, porque a gente está mais atenta, a gente observa mais. Antes de ficar nervosa, a gente tenta entender a criança. E isso não significa que eu não coloquei limites. Eu sou muito exigente para limites, mas eu só vou exigir limites depois da criança entender o que é aquilo lá. Então, a gente, desde o início, vai dando carinho, dando atenção, fazendo alguma troca nesse sentido, que existe uma troca, que eles podem confiar em mim, e eu neles, que eles podem contar comigo, e eu com eles. Que é o que eu falo sempre, a gente vai fazer sempre uma troca aqui dentro da sala de aula. Tudo que eu falei pra você eu falo para eles, assim mesmo. Mas, tem, geralmente, aquelas crianças que têm muita dificuldade para seguir as regras de comportamento, e aí a gente tem que ser um pouco mais rígida, mais dura, pôr os limites mesmo de uma maneira mais incisiva, para eles entenderem [...] Ah, eu acho que assim, muita conversa, muita atenção, eu não falo alto, eu falo baixinho. Eu dou muita atenção para a criança - eu falo que quando a gente está falando a gente tem que olhar para a pessoa - e eles quando falam comigo olhar para mim, e não sei, é uma porção de coisas que eu vou desenvolvendo neles, que leva, às vezes, um tempinho para um, para outros mais rápido. $\mathbf{E}$ imponho limites mesmo: "Isso não pode, e isso você não vai fazer, porque se fizer tem castigo". Eu dou castigo mesmo. Porque eu acho que a criança, ela tem que entender. Fez errado, ela tem que pagar pelo erro. E castigo que eu falo, é dar um castigo pedagógico. Eu dou uma cópia para eles fazerem. Porque aí já está aprendendo a escrever também, já está vendo as coisas, e ele fica muito constrangido porque ele é que está deixando de me ouvir, está deixando de prestar a atenção no que eu estou dando, deixando de fazer a lição, ele deixou tudo de lado para fazer a cópia.

Márcia, também se valendo de uma linha de pensamento diagnóstica, fala de conhecimentos de Jung, aprendidos no curso de Psicopedagogia, a partir dos quais interpreta e intervém nos comportamentos de seus alunos: 
Aquele quadro que ele tem: pensamento, sentimento, intuição, percepção. O que ele falava sobre esses canais eu usava bastante. A gente fazia muitos exercícios assim: uma criança que é muito sentimento, você tentava fazer umas atividades mais de pensamento com ela, tentar trabalhar o lado oposto, porque eu também me acho sentimento, e eu acho que a gente acaba puxando para o lado que é mais fácil. É mais fácil para eu trabalhar aquelas atividades mais ligadas ao sentimento. Então essa professora [da disciplina sobre Jung] fez várias apostilas das pessoas que são mais pensamento. Como elas são, que atividades que elas não gostam, o que elas poderiam trabalhar. Então eu usava muito isto. Nos meus estágios, no Jaguarée ${ }^{30}$, tudo. Uma pessoa que é mais intuição, tentar puxar para o outro lado, pra você acabar usando todo o seu poder. A gente acaba usando o que é mais fácil pra gente, vou te falar: a parte corporal pra mim é mais difícil. Mas eu quero trabalhar isso. Eu acho que é uma coisa que tem que ser trabalhada mesmo, porque eu tenho mais dificuldade.

A fala de Wanda é exemplar da presença da psicologia diagnóstica no dia-a-dia do professor:

E outra coisa que eu aprendi, se está dormindo [o aluno], deixa dormir. Isso eu aprendi com a psicóloga também. "Deixa, a hora que ele acordar conversa com ele, por que ele dormiu tanto. Se ele foi dormir tarde, que tem que dormir mais cedo...”.

A psicologia ensina o professor a diagnosticar e a intervir em problemas que, supostamente, não possuem qualquer vínculo com a escola. No exemplo acima, a professora segue as orientações da psicóloga sem questionar a existência de outros motivos que poderiam contribuir para o sono em sala de aula.

Esta possibilidade de ser “psicólogo” está presente em outros depoimentos:

Partindo mesmo pra realidade, eu achei que a psicologia me ajuda quando você tem que fazer o famoso “psicológico no aluno”. O camarada não que fazer, está desanimado, "a vida não me agrada, a vida não é boa, minha mãe me bate, estou triste”, então você tem que conversar com ele, com toda a calma, virando a situação para o que você quer. Você quer que ele aprenda. Só que, como ele está com a cabeça

\footnotetext{
${ }^{30}$ Favela da cidade de São Paulo.
} 
cheia de um monte de coisas, ele não vai aprender, porque ele não vai se concentrar naquilo que você quer, ele não vai pintar um patinho quando ele está pensando no tiroteio que aconteceu ontem, não vai. Então você tem que conversar sobre aquilo, aí “resolveu” o problema, porque você vai conversar com ele, ele vai desabafar, ele vai se sentir mais calmo, e dali pra frente você vai conversar sobre a sua lição, sobre a proposta que você dá em sala. Acho que isso foi vantajoso pra mim, eu aprendi a ter um jogo de cintura com o embasamento teórico que eu tenho, de todos os cursos. Consegui ter uma base para ter esse nível de conversa com meus alunos, acho que isso é importante [...] Porque quando eu estudo psicologia, eu não beneficio somente as pessoas que estão em volta de mim. Eu me beneficio. Porque se eu souber botar na minha cabeça no dia que eu estou cansada, "vamos lá, porque está no fim!”, isso é psicologia. Eu estou passando o famoso "psicológico" em mim mesma, mas eu estou me beneficiando, porque eu não vou largar pela metade, eu sei que, às vezes, a falta de estímulo, a falta de apoio, podem fazer uma pessoa desistir de uma coisa importante ou não [Carla].

Márcia, embora faça referências a teóricos da psicologia, no relato de situações pedagógicas nas quais utiliza conhecimentos psicológicos, mostra-se como psicóloga de forma semelhante:

Vigotski eu acho que eu consigo perceber bem onde que eu uso. Por causa dos conceitos de Zona de Desenvolvimento Proximal, que o mais avançado ajuda o que sabe menos, que você tem que fazer as duplas por proximidade. Às vezes quando a gente faz dupla, se você coloca uma criança que sabe muito, com uma criança que não sabe nada, também não dá certo. Você tem que saber dosar. E, às vezes, as crianças perdem muito a paciência para ensinar os outros. Então, eu já escolho os que têm mais paciência. Wallon, eu já não consigo perceber muito onde que eu uso, mais na parte emocional, acho. Mas, eu acho que eu consigo vislumbrar melhor o Vigotski, que eu estudei bastante tempo. E outra coisa que eu lembrei também, acho que uma área que eu usei muito foi com a minha filha, quando eu tive neném. Porque assim, as coisas de desmame, de fase oral, de entender como é importante a criança aos pouquinhos ir se separando da mãe. Então, por exemplo, o desmame dela foi super tranqüilo, ela mesma é que deixou, que eu ficava tendo fantasias, falando: "Ah, meu Deus, será que eu não vou conseguir?”. Porque eu tenho uma relação muito simbiótica com a minha filha. 
Esses dias que ela está passando mal, eu passo mal junto. Ela tomou café da manhã hoje pela primeira vez em três dias, eu tomei, pela primeira vez. Aí, eu, hoje de manhã, pensei assim: "Nossa, eu estou bem grudadinha, bem na simbiose mesmo". Porque ela fica mal, eu fico junto. Mas, é difícil, apesar de eu ter consciência. Então, eu usei muito com a minha filha. E aí quando tem alguma mãe aqui na sala também que tem alguma dificuldade de ser muito super protetora, aí acho que a gente usa muito isso. A gente conversa e fala como é importante o filho se tornar independente [...] E nessa fase da alfabetização, da aprendizagem da leitura e escrita, eu acho que pode acarretar uma dificuldade mesmo, da criança que é muito super-protegida.

Nancy também fala em tornar-se “psicóloga” em sua atividade de coordenadora pedagógica:

Porque, como coordenadora pedagógica, eu fazia tudo que não está escrito na lei [risos]. Ou seja, na lei está escrito: "coordenar os trabalhos dos professores, o planejamento, não sei o quê, não sei o quê". É o que eu fazia num tapa com eles. $O$ resto, eu ficava aqui em cima. Eu vivia aqui em cima, coisa que não acontece com os coordenadores. Eles querem ficar na sala deles e resolver quando alguém manda trabalho. Eu já fazia ao contrário. Por quê? Eu me sentia na pele do professor. Acho que isso a psicologia também me ensinou. Se colocar no lugar do outro. Eu me coloco muito no lugar do outro, e assim eu posso ajudar.

Como pode ser observado, são muitas as falas em que o papel do professor se confunde ao do psicólogo e ele passa a fazer diagnósticos, a explicar de forma psicologizante comportamentos e a orientar pais. Isto só é possível porque a aproximação entre ciência e senso comum fez com que conceitos de psicologia fossem assimilados à linguagem cotidiana:

Acho que eu sou mais uma grande mãe mesmo [risos]. Que eu sou assim. Que outro estava falando assim: "Ai, parece que é a galinha com os pintinhos". Acho que eu já estava dando uma desencanada, porque as crianças estão chegando cada ano com mais dificuldades. O ano passado os alunos não sabiam cores. Esse ano tem mais alunos ainda [que não sabem cores]. E tem uns que nunca estudaram, que não sabem pegar o 
lápis, é difícil. $\mathrm{Eu}$ acho que tudo melhoraria se fosse um trabalho mais individualizado. Se eu pudesse sentar do lado e acompanhar as dificuldades mesmo. Fazer isso devagar, para ver se dá resultado. Tem que ser rapidinho, senão vai causar indisciplina, aluno se matando ali. Então acho que tem que ter um jogo de cintura quando você quer fazer, por exemplo, dois, três trabalhos, já leva um tempo. Tem que ter um jogo de cintura porque tem as crianças que têm mais dificuldade. Então, são muitas realidades dentro da mesma sala que eu tenho que dar conta da minha obrigação como professora. Porque se eu fosse mãe de um aluno da minha sala, eu ia querer que ele chegasse com a lição feita e corrigida em casa. E quando eu dou o carimbinho, dois carimbinhos é porque está bem, é um incentivo. E aí de incentivar, porque eu acho uma coisa que todo mundo acabou usando da psicologia, que é de você reforçar o que o aluno tem de bom, reforçar o positivo. E tem um aluno com muita dificuldade, faz o mínimo, você fala: "Nossa, parabéns, está lindo demais, não sei o quê" e tentar fazer com que eles lidem com as dificuldades. Eu sempre falo pra eles que aprender a ler não é fácil. Eu também achei difícil quando eu era pequenininha, mas eu consegui. E, às vezes, tem criança que demora mais tempo, tem criança que é mais rápido, e de lidar com ritmos. Acho que respeitar a individualidade do aluno, saber que cada um tem a sua história de vida, cada um tem sua vida familiar, tem os momentos que está passando. A mãe grávida, os alunos estão com um pouquinho de ciúmes e acho que respeitar mesmo a criança, saber da fase, daquilo que a gente estuda, das fases da infância. Você saber de Piaget, saber em qual momento que eles estão, qual parte. E o que eles conseguem atingir, o que eles não conseguem [Márcia].

A dimensão “psicológica” da relação professor-aluno pode tornar-se preponderante, a ponto de o professor perder de vista o lugar de professor, detendo-se nos meios para obter os comportamentos esperados dos alunos. É isto que aparece com a expressão "ter jogo de cintura".

O “jogo de cintura” proporcionado pelos conhecimentos de psicologia pode ajudar a lidar com situações escolares que, a rigor, escapam à finalidade da escola:

Tem situação que você tem que se pôr na frente do aluno, porque uma pessoa de fora da escola, que vai assaltar a escola, não vai atirar no seu aluno. E aí você está pondo a 
sua vida em risco. Se acontecer alguma coisa comigo, ninguém vai fazer nada, problema meu. Só que, em contrapartida, se eu deixar atirarem no meu aluno, também a culpa é minha, porque a responsabilidade de zelar pelo bem-estar do aluno é minha. Então, às vezes, você tem que conversar com o camarada e explicar pra ele: "Você quer roubar a escola? Leva tudo o que você tem que levar, mas deixa a gente em paz”. Os estudos que eu li me ajudaram com isso, porque tem coisas que você não pode dizer, tem situações que você não pode perder a calma por mais difíceis que elas sejam, você tem que estar ali como um negociador, em cem por cento do tempo, principalmente nas situações de violência, que o seu homem natural fala pra você: "Minha filha, some daí!”, e você não pode sumir, você vai deixar seus trinta e oito alunos na sala com um camarada lá? [Carla].

A aproximação entre psicologia e senso comum garante que todos possam ser psicólogos ou "ter psicologia" para resolver problemas. Como são muitas as “psicologias”, cada um pode ter a sua:

A psicologia de uso é da minha experiência de vida. Porque eu já fui criança, eu já fui adolescente, eu já fui jovem e agora sou adulta, já estou indo para a terceira idade [...] Mas eu uso a minha psicologia meio que sem saber exatamente se é certo ou se é errado agir ou falar dessa forma [Sandra].

Ter psicologia se confunde com ter bom senso, saber dizer as palavras certas na hora certa, saber se controlar em momentos difíceis para bem lidar com as situações escolares. É ter “jogo de cintura”.

Carla fala da importância da psicologia em situações em que precisa se controlar:

Você entender dentro dos seus limites, dos seus parâmetros de vida, entender o máximo possível a criança pra estabelecer um convívio melhor. Não se alterar tanto, tentar fazer um trabalho mais harmonioso, mais de troca, mais de afetividade, sabendo colocar limites, mas infelizmente a gente tem uma gama muito grande de crianças com problemas diferentes, e personalidades diversificadas, coisas que eles trazem de casa que a gente às vezes não dá conta. Mas a gente precisa tentar entender mais a vida da criança pra poder fazer um trabalho mais harmonioso. 
A psicologia também aparece como um conhecimento que auxiliaria o professor a ter o controle ora do processo cognitivo dos alunos, ora da organização e da disciplina da classe:

Não há como haver um acomodamento harmônico meu, do meu querer com o querer do aluno, até onde o meu querer enquanto professora, imbuída da tarefa de que ele aprenda, mais o querer dele, até que ponto é de fato aprender? Você acaba compreendendo toda uma gama de quereres aqui num curso noturno de $E J A^{31}$, de determinada clientela, de classes sociais, que é uma coisa fantástica. Então, não há como o meu querer, desse lado aqui, acomodar-se de uma forma harmônica com o querer do aluno se não tiver uma estratégia. E eu acho que a primeira estratégia é você justamente estar sensibilizada, e eu acho que isto é uma questão de psicologia, que estou perto de um ser humano que tem outros quereres diferentes dos meus e que a gente vai ter que tentar harmonizar isso de alguma maneira, você entende? Eu acho que são práticas que a gente foi extraindo da identificação do aluno com o professor [...] Tem uma relação riquíssima, fundamental, que explica tudo entre o cognitivo e a psicologia. Então, tem todo um processo cognitivo aí se realizando na minha frente e eu estimulando ou não [Maristela].

E a minha sala está difícil, mas eu tento manter sob controle porque eu tenho um pânico com comportamentos de alunos em pé, bota a gente em pé, e tem que ficar sentadinho bonitinho. Tem uns que não sabem sentar, fica na frente da cadeira. E a mesa toda desarrumada. Eu tenho neura com... [risos]. Eu sei que eu sou assim. Tem que estar tudo organizadinho [Márcia].

O controle também é desejado para tratar de situações difíceis na escola que envolvem tanto alunos como os pais. Quando indagada se os conteúdos de psicologia vistos durante a formação lhe ajudaram em seu trabalho com os alunos, Wanda responde:

\footnotetext{
${ }^{31}$ Educação de Jovens e Adultos.
} 
Eu devo ter usado, eu devo ter usado. Porque era forte na época. Mesmo nessa escola que eu estou te falando, nessa escola a gente usava. Porque daí ficava conhecendo a criança de seis, sete anos, melhor. Então eu usava, eu lembro que eu usava [...] Criança, por exemplo, que chegava lá e que chorava. Chorava que não queria entrar na escola nos primeiros dias. Pelo o que eu lia, ficar amiga, tentar convencer. Eu falava: "Fica, você hoje vai ser meu ajudante. Olha, eu já estou com o apagador na mão. Hoje você vai apagar a lousa. Você vai me ajudar". E daí o moleque acabava ficando. De repente começava a chorar. Eu falava: "Ai, não chora não, porque tem uma aula hoje, e tem que pegar um papel lá na secretaria, e você é que vai pra mim, vou escrever aqui ó, pra você não esquecer, você leva lá o papel...”. Tipo de um ajudante, de um amigo, que está ajudando. Ajudava essas coisas assim, e eram coisas que a gente discutia com a psicóloga. Não chegar e falar assim: "Deixa a criança chorando aqui o dia inteiro". Ou então falar pra mãe: "Não, leva embora porque ele vai chorar". A gente tentava. E, às vezes, muitas, quase todas as vezes, dava certo.

Carla, assim como Wanda, cita como a psicologia pode contribuir para o trabalho de "convencimento" do outro, ao contar uma discussão que teve com a mãe de um aluno porque ela não compreendeu os bilhetes enviados pela professora:

E eu tenho que trazer essa mãe pro meu lado, ela tem que jogar no meu time, não contra mim. E aí que entra o meu embasamento teórico da psicologia, é a minha opinião. Se eu não tivesse embasamento teórico nenhum eu já ia mandar ela andar - "Ó minha senhora o negócio é o seguinte... Porque você falou um monte de absurdo pra mim e não condiz”. No entanto, ela percebeu que ela estava errada e por quê? Porque eu conversei com ela de uma maneira que ela entendesse que havia um engano sem que eu precisasse dizer: "Escuta minha senhora, você está errada”. Que apesar de ser o que o meu homem natural disse que ela merecia, não era o correto de se fazer. Agora da onde que eu tiro que não era o correto de se fazer? Do embasamento teórico que eu tive.

Maristela mostra a psicologia como auxiliar da mudança de relacionamento entre o professor e o aluno. Ao responder se, em algum momento de seu trabalho pedagógico, apesar da formação elementar, utilizava a psicologia, afirmou: 
Eu acho que de uma certa maneira mudar um pouco a identificação que os alunos sentiam por mim, eu acho que já é um indício. O professor tanto ele pode criar antipatia em relação aos alunos, como ele pode criar uma baita de uma empatia. Vamos dizer, sem perder níveis de exigência, de colaboração, você entende? Eu sou profundamente exigente, mas essa coisa de ser mais simpática, eles se sentem mais tranqüilos, eles podem confiar em mim, eu vou ser exigente.

Dessa forma, quando relatam que os conhecimentos de psicologia colaboram para lidar bem com situações escolares, isto significa a possibilidade de ter o controle do relacionamento professor-aluno, do processo ensino-aprendizagem e da disciplina, para obter adesão, consentimento, submetimento.

Ao falar sobre a psicologia, os depoentes também apresentam suas demandas $e$ expectativas a ela e aos psicólogos. O pedido é de socorro:

E nesse sentido então que eu coloco, que eu percebo entre nós, como o professor, ele sofre um desgaste muito grande. Talvez, inclusive, passa por aí a falta de subsídio, de novo, na cooperação, um trabalho mais integrado com coordenação pedagógica que assista melhor o professor. Que dê um suporte para ele, que ele não se sinta sozinho nos trabalhos em sala de aula. Não deveria se sentir, ele se sente. E eu acho que isso cria esse desgaste. Porque você não tem onde se socorrer, é o que me parece. Hoje em dia o professor parece, ele coloca na cabeça que é ele o professor, porque a coordenação não tem tempo para resolver, burocrático, toma o tempo dos profissionais da educação. E a parte realmente mais importante não acontece. Eu acho que o professor está precisando de um suporte. Ele está se sentindo isolado. E isso está desgastando o professor, no trabalho dele. Então eu sinto que ele está mais, ele se sente, não sei, mais desestimulado [Antônio Carlos]. 
O que desestimula o professor? O que o desgasta? Sente-se isolado e sozinho em quais circunstâncias? Com freqüência, nos depoimentos, é possível encontrar inúmeras queixas sobre os alunos que não aprendem e a psicologia serviria para lidar com eles:

Então eu acho que a psicologia poderia ajudar até nesses casos que a gente enfrenta do aluno que não tem o processo de desenvolvimento como os outros alunos. Quer dizer, a gente tem infinitos casos de pessoas que passam [são aprovados sem aprender] $e$ tentar resolver isso. E não resolve. O aluno passa, mas não resolve nada. E esses casos, como é que ficam? Como é que é esse processo, como entender, como pensa esse aluno? Como é que faz para fazer uma intervenção? A gente não consegue fazer intervenção nenhuma. O aluno simplesmente passa pelo professor, mas não sofre nenhuma interferência mais eficiente. Por falta de formação, de conhecimento do professor. E não é só do professor [Antônio Carlos].

E então acho que é isso que pode ajudar a psicologia. Acho que ajudar a entender mesmo o aluno. $\mathrm{O}$ que é importante pra ele, ou as dificuldades que ele passou desde a infância e que afetam a aprendizagem. Daí bota anamnese nele. Conversas com alunos que têm dificuldade, que às vezes são casos mais sérios, e já tentar fazer uma anamnese, fazer uma análise mais profunda, chamar a família um dia [Márcia].

Pra mim, a psicologia dentro da escola é basicamente isso, o que a gente está vendo são duas coisas: indisciplina e bloqueios de aprendizagem. Se a gente tivesse um psicólogo por escola - não estou falando dessa escola - todas as escolas a gente houve falar, têm esses dois grandes problemas: de disciplina e desses bloqueios de aprendizagem que a gente não sabe por que a criança não avança. Aquelas que não se alfabetizaram mesmo, tem alguma coisa acontecendo aí no meio que a gente não sabe. Então, seriam os dois grandes eixos. Se tivesse psicólogos orientadores pra gente se focar um pouco e saber trabalhar melhor, seria ótimo. São esses dois grandes problemas que eu vejo numa escola [Nancy].

Os educadores desejam compreender como o processo cognitivo ocorre: o que se passa na cabeça das crianças e dos adultos que não aprendem e que não se comportam adequadamente na escola? A resolução de problemas de aprendizagem e de ajustamento 
está vinculada a uma psicologia normativa e classificadora, o que demonstra aquilo aprendido no contato com psicólogos e nos cursos de formação, como será visto no próximo capítulo.

Mas, ao mesmo tempo em que desejam a intervenção do psicólogo para os casos individuais - queixa antiga da pedagogia para a psicologia que repõe o mito do atendimento individualizado como solução para os problemas de aprendizagem - parece haver algo novo na solicitação dos professores:

E acho que a psicologia também poderia estar ajudando em alguns casos de inclusão, nesse sentido. Até, psicologicamente, trabalhar a ansiedade do professor. Não sei se essa ansiedade passa por uma questão psicológica do professor mesmo em si. Mas para fortalecer o professor ou tranqüilizar ele. Eu acho que até umas expectativas. E ele se quebra muito, acho que quando o trabalho não é bem feito, é ele só o responsável. Até onde é responsabilidade do professor, onde não é? São essas questões, professor se depara com uma questão nova e não está preparado, vai se sentir impotente até. E trabalha com essa impotência com essa sensação de incapacidade mesmo [Antônio Carlos].

Antônio Carlos, além de outras demandas para a psicologia, fala longamente sobre o processo de inclusão:

Eu acho, de conhecer o processo de construção do indivíduo, como ele pensa talvez. Eu acho que isso é um pouco que talvez a Emília Ferreiro faz, não sei -você que está nessa área - não sei, mas parece que, entre linhas, o que ela coloca, tem no trabalho dela um pouquinho dessa coisa da psicologia também, e entender o processo lógico das pessoas, como é que elas pensam. E não sei se isso também está ligado à psicologia propriamente dita, ou a uma outra área da Biologia. Mas eu acho que nesse sentido também, eu acho que o trabalho da Emília Ferreiro um pouquinho, quando eu lembro da Teberovsky, da Ana Teberovsky, parece ter uma sinalização também, de entender o processo de construção do pensamento das pessoas. Eu não sei, talvez nisso também a psicologia pode estar ajudando. Outra coisa, eu acho, é com aquelas crianças que têm necessidades especiais. Eu acho que ali a psicologia também é um pouco mais forte. Do professor diminuir a ansiedade dele, a frustração dele, e tentar se aproximar e acho 
que a psicologia poderia estar ajudando um pouco. Acho que a gente tem crianças aí com dificuldades, até eu acho que no Estado, tinha lá os DMs, as crianças deficientes mentais. E também se usava muita psicologia, também, um pouquinho, pra tentar minimizar a violência das crianças, apesar que não tinha muita parte lógica nesse caso, mas a gente tentava usar da psicologia também na formação dos professores, pra tentar lidar com essa clientela especial. Então, eu acho que nessas necessidades especiais que essas crianças hoje da inclusão estão trazendo pra escola, acho que também tem um pouco do psicológico como trabalhar isso. Até das crianças, talvez elas venham já frustradas, quem tem alguma deficiência já vem um pouco se sentindo excluído ou discriminado pelos outros colegas, e tem que trabalhar essa criança também pra que ela supere isso, que avance, e acho que também é papel do professor ajudar nisso. E que hoje só se fala nisso, inclusão, inclusão, inclusão, inclusão [...] Eu acho que um dos pontos é trabalhar não só o professor, todo mundo da escola que está recebendo esse aluno [de inclusão]. Porque eu acho que até a deficiência, a família, quando ela recebe a deficiência na tenra infância, existe um trabalho até terapêutico para aquela família saber lidar com aquele problema que está aparecendo na família. Muitas vezes, a família faz uma terapia para entender aquele caso e saber superar as dificuldades que vão encontrando. É um choque para toda a família: "Eu tenho uma filha deficiente. Como é que eu vou tratar disso? Eu não sei”. Vai buscar uma formação, porque é até um trabalho, faz uma terapia para tentar entender aquele problema que é novo dentro do seu meio. Mas, com a escola é a mesma coisa. Eu acho que todo mundo sente. É o choque. A princípio não deixa de ser. Tanto com a criança, como os professores que não sabem trabalhar. $\boldsymbol{O}$ choque tem o novo. Pela novidade, e não tanto pela formação $e$ o preparo para receber aquela situação. É nesse sentido. Porque eu penso na hora que a psicologia poderia ajudar. Em alguns casos específicos eu não coloquei antes, talvez algumas escolas ou tipos de inclusão, também são casos específicos da psicologia, e que aí seria campo de estudar psicologia, que poderia ajudar a gente. A entender aquele caso um pouquinho. Que forma, ou que metodologia, ou que forma de abordagem você tem que ter com um determinado caso, por exemplo? Um deficiente mental, por exemplo? Que a psicologia ou a psiquiatria, não sei, como é que eu trato a violência, no $D$. [um de seus alunos], por exemplo? Que forma de abordagem eu tenho que ter quando o aluno está violento? Ou quando ele não me ouve? Quando ele está viajando? Que tipo de abordagem tem que fazer? Eu acho que em alguns casos a psicologia poderia ajudar, por exemplo. É campo de estudo. 
Carla deseja parceria:

Acho que falta uma pessoa para nos ajudar nos estudos de casos individuais, acho que é onde a gente mais sofre. Porque, às vezes, você pega uma criança numa situação e você quer ajudar ela e aquilo te frustra, porque você não consegue ajudar aquela criança, $e$ você estuda, estuda, estuda, e a coisa não vai pra frente. Eu acho que às vezes a gente precisa de uma coisa mais dirigida, uma pessoa, que viesse um dia, assistisse um dia de aula, depois conversasse individualmente com aquela criança, e falasse assim: "Olha, vamos tentar isso aqui", que às vezes você tenta sozinho e não acha uma luz. Em contrapartida, uma outra postura fala que escola não é hospital, então você não vai ter uma pessoa atendendo, você não quer que aquela pessoa atenda aquele aluno, você quer que aquela pessoa conheça aquele aluno e te dê um norte, e não que a pessoa atenda aquela criança pra curá-la. A cura ela vai procurar no hospital. A gente precisa de uma pessoa, que nos casos mais agressivos, onde o comportamento da criança está ligado a fatores externos, que a gente não comanda. Por exemplo, eu tenho um aluno que é extremamente agitado, não é uma má criança, não tem instinto de me agredir, fazendo uma maldade, não se sente bem fazendo maldade, não faz de propósito pra ver o outro sofrer. Só que ele chega em casa à noite, e ele tem que ficar trancado, até a hora da mãe chegar e de manhã quando a mãe sai pra trabalhar ela tranca ele, $e$ a moça da perua tem a chave da porta e destranca o menino. Quer dizer, o menino fica o dia inteiro trancado, a noite inteira trancada, quando ele sai para vir pra escola, quer pular, quer correr, quer fazer de tudo que ele não faz em casa. Uma pessoa que tem que nos ajudar, dando um norte pra gente conhecer o que é que a gente poderia estar dizendo pra aquela mãe, que faria com que ela entendesse que o fato dela trancar o filho todos os dias faz com que ele fique agitado aqui. E, no entanto, quando a gente fala pra ela: "Ele está muito agitado, que tal se a senhora fizesse isso, fizesse aquilo?", aí ela chega em casa "você fica quieto, isso, isso e aquilo", e bate no menino e não é o que eu quero. É esse tipo de coisa que falta. Uma pessoa que seja de fora, que tem uma cabeça boa, um bom embasamento teórico, e fale pra você: "Olha, você já tentou isso?”. Às vezes, a gente procura, mas não acha uma solução, sozinho a gente não anda, e não vai pra frente. 
Os problemas de aprendizagem, como mostram as falas acima, ainda são vistos isoladamente e os alunos são desvinculados do contexto escolar. Contudo, como pode ser observado, não há pedido de encaminhamento psicológico para fora da escola. Ao responder às questões que lhe foram feitas, os depoentes não pedem apenas que o psicólogo trate de seu aluno que não aprende ou que não se comporta de acordo com as normas pré-estabelecidas pela escola. Querem, além disso, serem ouvidos, dividir sua angústia, por isso relatam para a pesquisadora inúmeras histórias suas com seus alunos e não apenas deles. A ênfase está na relação entre professor e aluno e, portanto, na dificuldade que sentem no trabalho com os mesmos. Desejam saber o que fazer para encontrar soluções. Carla, a seguir, explica sua necessidade em compreender o que se passa com seus alunos para que ela possa intervir:

$\mathrm{Eu}$ acho que por isso o psicólogo deveria estar aqui, explicando essas coisas, explicando os diferentes tipos de doenças mentais e tudo o mais, tem um jeito de você interagir, tem um jeito que você consegue tocar. Aquela criança que tem um problema mental, ela vai te entender, só que você tem que agir diferente do que você age com outras crianças que não têm essa deficiência. E eu acho que o psicólogo poderia estar explicando para o professor que tem essa criança, como interagir, como tocar essa criança pra que ela aprenda. Eu acho que isso é o que pouca gente entende.

A professora quer saber como fazer de um outro modo para atingir aqueles que não aprendem. Da mesma forma, Antônio Carlos, acima, gostaria de ter contato com abordagens, metodologias que o ajudassem a chegar mais próximo de seus alunos de inclusão. Márcia, a seguir, aponta a necessidade de encaminhamento psicológico, mas quer sugestões para lidar com as dificuldades dos que não aprendem:

Porque às vezes, a gente não sabe como lidar com alguns problemas. E talvez você acabe prejudicando a criança. Então eu acho que é assim, um aconselhamento mesmo, ter alguém pra falar: "Olha, eu acho que você podia tentar fazer assim". Dar alguma sugestão e também fazer um trabalho com as crianças, porque tem criança que precisa realmente de encaminhamento psicológico. Você sente que é uma barra em 
casa, sabe que a vida deles dá dó, quando você toma conhecimento. E aí chega aqui na classe, você não pode mudar a situação.

Wanda quer entender por que seus alunos não aprendem e questiona explicações psicológicas tradicionais, mesmo que não se dê conta disso e, logo em seguida, utilize velhas crenças sobre fracasso escolar:

Olha, nesses casos que eu te falo que não aprendem nada, mas não dá, eu não sei te explicar, não aprende mesmo, o máximo que faz é copiar, ou copiar muito mal, eu acho que precisava. Para saber o porquê. Se enxerga, se escuta, por que não aprende um pouco? Um pouco? Não precisava aprender como os outros. Mas um pouco. E eles ficam, e eles não vão embora [os alunos adultos não vão embora da escola, mesmo que não aprendam]. Eu tenho umas três, quatro senhoras na minha sala, que é de segunda e terceira, que já estão há vários semestres. E elas não conseguem formar uma frase. Copia direitinho da lousa. Tem capricho, tudo, mas não consegue. Aí o pessoal fala: "É limítrofe. É limítrofe, é limítrofe”. Mas pô! Tem um jeito. Eu não sei o que fazer, mas talvez o psicólogo possa estar falando, conversando... E dar a dica: "Olha, é doente, tem problema, precisa ir pro médico, precisa tomar algum remédio, está com a memória não sei o quê, tem muito problema em casa, vem para escola só para jantar”. Dar uma ajudada. Porque não dá para você saber tudo também. A gente tenta bastante.

O diagnóstico e o encaminhamento trazem alívio ao professor, como aponta Sandra:

Mas eu acho assim, que só o fato de diagnosticar, que existe um problema, já é um passo grande. Porque, por exemplo, déficit de atenção. Eu, no ponto de vista da minha leiga, leiguíssima, eu acho que tem que tomar remédio pra déficit de atenção, não adianta só conversar, só passar para o psicólogo, só uma vez por semana, isso tem que ser resolvido quimicamente, com remédio. Aí já encaminharia pro outro profissional, não ficaria mais com o psicólogo. Então já sairia de uma área, já iria para outra. Isso já seria um passo muito grande. Agora a maioria dos alunos que já passaram por psicólogo volta como "o aluno não tem nada". Aí complica. Porque você acha que tem. Mas se tivesse esse contato, que a gente estava falando, com o profissional, do 
professor com o profissional, se ele não consegue fazer isso, se ele não consegue aquilo, se ele não pára, aí já teria mais argumentos para o profissional trabalhar. Ah, então ele não consegue ter atenção, então ele vai fazer um teste de atenção - não sei se existe, estou falando por acaso. Agora, a partir do momento que já está diagnosticado: “Ah, não é a minha área”, ele vai pra outro médico, neurologista, psiquiatra, tentando encaminhar. Seria muito bom. Se pelo menos nessa primeira triagem a gente conseguisse passar os alunos - os alunos, os filhos, com a gente mesmo - com maior facilidade. Mesmo que o psicólogo falasse assim: “Ah, ele não tem nada, ele é normal”, mas já teve uma tentativa, né?

Como se pode observar na fala dos depoentes, mantém-se a expectativa clínica, do diagnóstico e do tratamento da criança, mas não da forma tradicional. Antes, o professor encaminhava para fora das escolas a criança com dificuldades; agora ele quer um psicólogo dentro da escola, não para montar um consultório, mas lidando com os casos difíceis junto com o professor; afinal as “dificuldades de aprendizagem” e de “ajustamento escolar” generalizaram-se:

O psicólogo tem que estar aqui pra ajudar a gente a compreender esse aluno e ter uma maneira diferente de interagir com esse aluno, pra que ele aprenda e pra que ele possa se desenvolver. E não uma clínica pra cuidar [Carla].

Os professores possuem até mesmo uma crítica pragmática da psicologia: querem saber como o aluno é ou o que fazer com ele, mas levando em consideração o contexto educacional, o aluno concreto. A psicologia deveria servir para dizer como os alunos são e como lidar com eles da maneira como são a fim de que possam ensinar conteúdos escolares.

Neste sentido, procuram parceiros, trabalhos em grupos, reuniões coletivas, horários curtos com o psicólogo, mas freqüentes, para discutir as dificuldades enfrentadas. Não se trata simplesmente de encaminhar ou "livrar-se" daquela criança que atrapalha porque não se encaixa e não aprende, uma vez que a maioria dos alunos não atinge as metas propostas para cada série. O professor deseja o psicólogo dentro da escola e, muitas vezes, dentro de sua sala de aula, para dividir, compartilhar, aliviar suas 
angústias. O psicólogo seria o apoio naquelas situações em que não sabem mais o que fazer, quando se encontram desesperados. Nestas condições, ele poderia trazer uma luz, um norte, orientações:

Porque essas crianças que estão chegando [os alunos de inclusão], elas estão chegando e eu não vejo nenhum trabalho específico, e não por conta dos professores, é por falta de formação dos professores. As pessoas não sabem o que fazer. Então não é fácil, não é fácil. Eu acho assim que a gente poderia ter trabalhos de dinâmicas em grupo na escola, com um grupo de professores, até com crianças, poder criar situações de dinâmicas com as crianças, que pudessem em momentos críticos poder então: "Vamos dar uma parada, vamos fazer uma dinâmica”. Acho que isso ia ser legal. E eu penso assim bem cegamente, sem experiência, mas que a psicopedagogia ou a psicologia tem muito a contribuir, deve ter muita experiência pra passar nessa área da educação, que a gente precisa de alguma forma trocar isso, trocar essas informações [Antônio Carlos].

Eu acho que o psicólogo deveria entrar na sala um dia ou outro, sabe? Se fazer meio que inerte, dar uma observada, pra estar ajudando o professor a compreender aquele aluno pra que ele possa aprender. Eu acho que tinha que ser assim. Eu acho que tinha que ser estudo de caso, eu acho que tinha que ter um dia, dois na semana com horário separado pra isso e as outras pessoas ouvindo e tentando aprender com aquele caso, porque um dia talvez eu possa ter uma criança naquela situação [Carla].

Eu acho super importante, eu acho que é uma parceria ótima assim, educação e psicologia, acho que necessária até eu diria, porque a gente sente muita falta. Coisas que a gente não sabe, aí vai perguntar para a coordenadora, mas ela também não sabe, ela não tem certeza. Então eu acho que é essencial, seria essencial ter um psicólogo na escola, pelo menos um. Não daria conta de tudo, mas já ajudaria ter uma pessoa disponível para você tirar dúvida, para, de repente, ver um caso mais gritante, pra fazer encaminhamento, que a gente tem muita dificuldade na hora de escrever, mesmo na hora de escrever um encaminhamento, os termos que você usa [Márcia].

Então a psicologia devia estar dentro da escola, não só passando para professora. É lógico que uma coisa ou outra... Uma palestra, num dia diferente com uma atividade 
sobre psicologia que alerte a gente por alguma coisa que a gente não está enxergando... legal. Mas a gente sabe da necessidade. E não é capaz de ser psicóloga junto com professora. A gente tenta, eu tento ser. Às vezes eu até erro, às vezes eu até acerto. Eu vou nas tentativas. E não é aquela teoria só, sabe? Porque aqui na prática é outra. Então eu acho que precisava mesmo era ter a psicóloga aqui dentro. Não só na formação, não. Pegando professor para estar ensinando. Sim, pode estar lembrando, abrindo a cabeça - que às vezes fica meio adormecido aquilo. Você: "Ah, pô! Podia ter feito isso, tal...”. Um psicólogo que viesse de vez em quando bater um papo na sala dos professores, ou numa sala com todos. Fazer uma atividade, chamar a atenção. Legal. Estar acordando a gente de novo, porque a gente adormece. Agora, o ideal seria a psicologia estar aqui dentro, não estar só formando junto os professores. Estar junto da escola mesmo, junto com os alunos também. E é lógico que os professores sendo assim, vão aprendendo também. Então tendo contato direto nisso. Tem alguém aqui dentro, está agindo de certa maneira com o aluno, que é um problema, você está vendo como ela está agindo. Você está aprendendo também [Wanda].

Ao invés do Moto-serra [referindo-se ao prefeito de São Paulo, José Serra] pagar a cesta básica, ele poderia pagar umas terapias de grupo aí pra nós [risos]. Terapia de grupo, uma sessão de auto-flagelo coletivo [risos] [Maristela].

E esse psicólogo, não ficaria só com as crianças, por exemplo, os adolescentes. Poderia ter, dentro da nossa hora de reuniões coletivas, ele também ter um ou dois dias para conversar com a gente, para colocar de volta o problema para a gente, com relatórios, sabe? Assim com uma coisa bem registrada, para a gente seguir, para ele orientar a gente. Seria um trabalho bem legal, eu acho, bem grandioso, que todo mundo ia sair bem. Porque ele trabalharia com outra pessoa, com os alunos. Seria uma coisa bem completa. Porque o professor não pode ficar distante dessas situações, ele tem que fazer parte dessas situações, não é só jogar para o psicólogo. "Ó: esse aluno está dando trabalho, resolve aí”. Não. Acho que o professor tem que estar junto, resolver junto, aprender junto com o psicólogo. E também, ajuda tanto o professor quanto o psicólogo. Porque não pode cair tudo na mão do psicólogo, tem que fazer um trabalho coletivo, com todo mundo. Com os operacionais, com a diretora, com a coordenadora, todo mundo falar a mesma língua [Nancy]. 
Quando você tem uma palestra, ou um estudo, ou é um grupo de estudo, periodicamente com um profissional, acaba surgindo o troca-troca das experiências tanto de um professor, às vezes, não é minha experiência e nem minha dificuldade, mas só de um outro professor comentar sobre as suas dificuldades, isso também serve pra mim. Então eu acho que o que eu percebo agora é mais a dificuldade que eu tenho com o aluno que eu não consigo ter um retorno. Que nem esse que saiu agora pouco. Eu não quero ficar brigando com ele o tempo todo e falando: “copiar, copiar, copiar”. Então, o pessoal pode até falar: "Ah, a sua aula não está muito boa”. "Então está bom. Então o que a gente faz pra melhorar?” [Sandra].

A diferença é que o professor incluiu-se na lista dos que precisam de ajuda, não só profissional, mas também pessoal. Quer alguém que divida o peso, o fardo; um acompanhante, parceiro, que o ajude a encontrar soluções. Por isso, é tão freqüente expressões como: ajuda, suporte, auxílio, respaldo, contribuição, orientação, apoio palavras destacadas nas falas anteriores.

Mas em sala de aula, acho que todo mundo percebe o esgotamento dos professores com relação ao trabalho. "Ai como eu estou cansado", em plena segunda-feira, "Ai que bom que está chegando o...”. Ou então ele já está na quarta-feira pensando no fim de semana, porque não agüenta mais. Então eu acho que é um pouco disso, dele se conhecer melhor também, saber se ajudar, e acho que as pessoas, a psicologia até pra si, pra nós mesmos. Eu conheço tantos colegas que fizeram psicologia, porque eles falavam assim pra mim: "É pra eu me conhecer melhor, porque nem eu me conheço". Quer dizer, tinha aquela dificuldade de relacionamento com as pessoas e sentia que aquilo era uma dificuldade dela de se transmitir. Então, pra se entender melhor $\boldsymbol{e}$ se fazer entender, entrou pra essa área. Eu sou uma pessoa que, a princípio, eu tenho uma convivência legal, eu sinto isso, de ser uma pessoa que qualquer lugar que vai eu consigo romper essa coisa. Eu não sou uma pessoa que crio barreiras, tanto com colega como com aluno, mas mesmo assim a psicologia é uma coisa que me atrai, mas, por falta de tempo mesmo, que eu não tenho podido me aprofundar mais [Antônio Carlos].

Não é aquela coisa assim: "Ai, o camarada [o psicólogo] vai resolver meu problema". Não é isso. Só que ele vai te dar uma luz, ela vai te dar uma opinião, que talvez aquilo 
você não pensou ainda e você ainda não tentou. E aí talvez se você tentasse aquilo, alguma coisa ia acontecer e ia ser positivo pra ambos os lados. Porque você ia compreender o problema do aluno e ia dar uma relaxada, não ia ficar estressada achando que ele te odeia, ele faz aquilo pra te magoar e ele ia entender que você se preocupa com ele e que por isso ele vai aprender [Carla].

Então, tem coisas também da vida da gente assim que seria legal a gente poder conversar também, mas aí eu sei que coisa particular. Então, eu acho que tem que ter [momento] coletivo com os professores, partes individuais, mas como se trata de escola, não falar o que eu estou te falando meu, falar o que acontece na sala de aula. Tentar resolver os problemas aqui dentro, pra gente pelo menos ficar com a cabeça mais tranqüila pra poder ter os problemas lá fora, que é da sua vida [Wanda].

Que a gente pudesse ter auto-conhecimento, se entender um pouco melhor enquanto profissional, enquanto o cara que está lá na sala de aula ensinando [...] Mas eu também entendo a psicologia no sentido dela contribuir pra humanização do trabalho da escola. Tanto é que eu falo da questão do auto-conhecimento do professor, um processo que eu passei também, que foi uma experiência muito gostosa. Então, eu acho que o grupo é coadjuvante também na questão cognitiva. Mas, eu percebo dois nós neste trabalho todo, do professor na escola. Que é como tornar o processo de ensino e aprendizagem também uma possibilidade de relações humanas mais sinceras, mais cooperativas, com maior compaixão nessas parcerias todas que a convivência humana nos torna assim predispostos, suponho, né? Que é a relação professor-aluno, e com os meus colegas, e tudo mais [...] E ou bem a gente não consegue entender o que são esses problemas - as causas, as conseqüências - ou bem a gente reconhece a existência desses problemas, mas também não sabe bem como resolvê-los. Pra que o espaço da escola seja um espaço bom, interessante, que faça algum sentido na vida do aluno, na minha vida também [Maristela].

Então, se nós tivéssemos hoje uma psicóloga eu acho que primeiro ela poderia, além de todo o trabalho que é feito em consultório, que é uma coisa individual e em outro ambiente, ela também poderia perceber como é que é na escola. E também ter - eu acho que também todo mundo tem uma noção do que é escola - ter uma noção maior do que é escola. O que aquele aluno, dentro desse ambiente, talvez ele não seja 
totalmente destrambelhado fora daqui. Mas entrou aqui, ele tem uma outra reação, um outro comportamento. Acredito eu, por exemplo, voltando ao $D$. [um menino que foi seu aluno no ano anterior]: que na casa dele não se detecta o que a gente percebe aqui. Por quê? Lá a mãe não está preocupada se ele fica na fila, se ele senta na carteira porque lá é a casa dele, ele vai sentar no sofá, na cadeira, em qualquer lugar, sem se preocupar com ordem, se chegou a sua vez, se não chegou a sua vez. Ter limites pras coisas. Então eu acho que estando o psicólogo no ambiente escola, ele tem mais possibilidade de entender o que a gente está necessitando. Do que a escola está necessitando, do que o professor está necessitando, ou até mesmo do que o aluno está necessitando. Porque ele tem uma ciência, ele conhece uma ciência que eu não conheço. A minha é limitada, a dele é maior. Ele talvez não saiba dar aula, ou como dirigir uma matéria, um conteúdo, mas ele entende outras áreas que eu não entendo. Então já teve uma intervenção mais rápida, mais próxima, mais urgente. Se eu precisasse conversar com ele hoje, sobre o L., que é meu aluno desse ano, sobre o G. que eu não consigo chegar no G. de jeito nenhum - se ele tivesse aqui, ele poderia conhecer o G., o L., ver quais são as minhas dificuldades com ele, conversar com ele, fazer cada um o seu papel [Sandra].

O trabalho junto com o psicólogo é desejado para solucionar qualquer tipo de problema. Diante de situações desesperadoras e da constante falta de resultados no processo de ensino-aprendizagem, a psicologia serviria para aliviar todo tipo de sofrimento, isto é, traria o alívio da dor, qualquer que fosse ela. Erroneamente esperam que a psicologia, por meio da presença do psicólogo nas escolas - e não na formação alivie ou amenize as angústias e os conflitos, mas não percebem os problemas estruturais da educação atual e o desmantelamento intencional da escola pública. Não há questionamento das práticas pedagógicas - a escola é uma realidade inquestionada, apesar de denunciada, como será visto posteriormente. Assim, a psicologia poderia trazer ao professor a diminuição de sofrimento, angústias, frustrações e solidão. Pedem essencialmente ajuda e, a sua maneira, cada depoente foi porta-voz de uma das formas deste pedido.

Antônio Carlos deseja trabalhar os relacionamentos humanos na escola e sempre fala sobre a necessidade de resgatar o grupo escolar: 
Eu creio que restabelecer as relações de novo entre as pessoas. As pessoas saberem o papel de cada um. Porque você não está sozinho no trato com o aluno. Eu tenho que sentir apoio no trabalho dele, e nas questões que ele enfrenta, na coordenação, na direção. Não necessariamente da escola. E muitas vezes parece que o problema parece só fica isolado ao professor e à sala de aula. Não há, não se compartilha as dificuldades do professor com o restante da escola. Então eu acho que resgatar o grupo, trabalho em grupo. Eu acho que o trabalho da psicologia é tentar resgatar o grupo, o grupo escolar, não é? Que a questão do professor é o problema da escola. $O$ problema do professor em sala de aula é problema da escola, não é só do professor. Nesse sentido, comentei. E restabelecer essa relação de grupo. Uma terapia, não sei...

Márcia sofre por não saber o que fazer com as classes heterogêneas e com sua aluna que possui síndrome de Down:

Uma coisa que eu acho gritante no momento é o como fazer, como lidar com os alunos de inclusão. Acho que tem a ver. Não sei, mas, é uma coisa que eu espero, porque são comportamentos diferentes. No caso, sendo que eu estou com uma Down, é mais diferente ainda porque ela tem muita dificuldade de comunicação. Ela é um doce, uma graça, super afetiva, mas ela, às vezes, tem uns surtos de chutar um, bater no outro e dar uns berros $e$, às vezes, eu não sei como lidar com esta situação. Não sei se eu disfarço, se eu deixo quieto, ou se eu explico para os alunos. Então, eu acho que lidar com esses alunos de inclusão e, além desses alunos de inclusão, como eu posso fazer pra ajudar os alunos que têm mais dificuldade de aprendizagem mesmo. E também acho que como você - mais aí não sei se é a psicologia ou se é a pedagogia - como trabalhar numa classe tão heterogênea. Que você fala uma coisa que pra um parece grego, o outro fez muito rápido: "Nossa, muito fácil". E pra um, de repente, é outra língua que você está falando. Estou tendo muita dificuldade com os dois alunos que nunca freqüentaram a escola, pra eles tudo é difícil. Tudo. E estou tentando deixar alguém do lado com eles, porque eu não dou conta mesmo de fazer o tempo todo as coisas com eles, mas mesmo assim não é suficiente. Eles vão toda a hora na minha mesa, e tudo pergunta, tudo você explica dez vezes. Então, como lidar com as diferenças, resumindo. Todas essas diferenças. Porque além das diferenças que a gente já tinhaque as classes sempre foram bem heterogêneas - agora ainda tem mais a diferença das inclusões. Que, por enquanto, tem uma em cada sala, mas que as previsões são que vá 
aumentando o número de inclusões. Então, acho que daqui a pouco vai ter mais do que um. E parece que você tem que dar uma aula diferente pra cada fileira, mais ou menos assim. Já até teve sugestões de dividir a lousa em várias partes. Mas, gente, isso é muito complicado, porque, e na hora de corrigir? [...] Então, como lidar com essas diferenças de níveis de aprendizagem e, às vezes, de comportamento também? Que eu acho que, às vezes, questão de disciplina, também a psicologia pode ajudar um pouco. Porque, às vezes, tem um fundo emocional ou, às vezes, algum problema mesmo que a criança está passando.

Maristela deseja o espaço da escuta:

Um bate-papo que trouxesse algum tipo de alívio. Que aliviasse as angústias e conversar a respeito. Tem alguns colegas que você até encontra um certo apoio, mas é o mesmo contexto. Alguém que pudesse fazer a gente pensar sobre outro viés, sobre outro aspecto, nesse sentido também. Tem hora que fica todo mundo como barata tonta. No final da história é tanta barata tonta que nos esbarramos. Não sei, talvez o psicólogo na escola desse conta de ajudar a gente a dirimir um pouco essa angústia: "Olha: você não acha que seria bom agir dessa maneira, ou agir dessa outra, afinal de contas tem um embasamento teórico que diz que as relações humanas são assim, mas podem ser assadas?”. Ou talvez se a gente conseguisse só começar a discernir... Eu não acho que o psicólogo seria necessário o tempo todo. Então, a minha visão é essa: tanto poderia ter um profissional de psicologia na escola, tanto poderia melhorar as relações humanas, como poderia também melhorar a questão da metodologia. Sabe, não chega outras visões, outras possibilidades. São sempre as mesmas.

Sandra busca encontrar uma psicologia mais próxima de seu dia-a-dia, que, segundo sua análise, estaria bem distante dos cursos de formação. Quer contato com o psicólogo:

Eu gostaria que a psicologia fosse mais acessível, entendeu? Que a gente tivesse assim, como você tem um posto de saúde onde você tem os médicos, que também tivesse um órgão, um lugar onde você pega o seu filho e fala: "Hoje eu quero passar pelo psicólogo", e consiga esse atendimento com as unidades. Porque eu não sei se tem 
poucos profissionais na área, ou o que acontece. Só sei que fosse gratuito, que fosse mais acessível, que você conseguisse passar com uma certa agilidade [...] Então se tivesse mais profissionais, igual ao médico que atende, sei lá, vinte pacientes por dia. Aquelas consultas muito rapidinhas, mas tem aquela rotina de ir lá, de conversar, de falar sobre o que a gente fala aqui, retomando os assuntos. Seria muito bom mesmo.

Carla gostaria de orientações, de ter a possibilidade de discutir os casos dos alunos que não aprendem para encontrar novas maneiras de interagir com eles:

É uma coisa muito importante que as pessoas têm que entender que se o psicólogo for para a escola ele não vai clinicar, ele vai contribuir para que seu trabalho deslanche de algum nó que você possa ter na sala. Ele não vai clinicar nem com você e nem com o aluno, ele vai te orientar para que a coisa vá para frente. Acho que a primeira coisa é as pessoas entenderem isso. A segunda coisa é todo mundo ter uma base, não pode trabalhar com uma pessoa que não saiba nada de psicologia porque aquilo não vai andar mesmo assim. Bem ou mal ela tem que ter uma noção, e a partir daí estar vendo, discutindo os casos, eu acho que essa discussão de casos faz diferença. Eu tenho um caso, então vamos supor que tivesse uma escala, eu teria quinze minutos para falar com você por semana, vamos supor que você fosse a psicóloga do caso, eu ia sentar com você quinze minutos e falar sobre o aluno. No decorrer da semana, você arranjaria um tempinho, visitaria a sala, ficaria um pouquinho, dar uma observada e voltar. Na outra semana onde eu tivesse meus quinze minutos e me dar um respaldo, sugestão no problema. Eu acho que tinha que ser uma coisa para contribuir para o que eu estou pensando a respeito, e eu acho que aí resolveria.

Nancy mostra a necessidade de a psicologia contribuir na prática com o professor, ao mesmo tempo em que denuncia:

Agora, o governo acha bonito falar: "Olha, as escolas estão com inclusão", e manda, é síndrome de Down, é deficiências múltiplas. E o professor se vira, se vira sem saber como, por intuição. Então a gente está precisando de bastante respaldo mesmo. Eu acho que a psicologia poderia ajudar bem assim na prática. É isso que eu acho. 
Wanda aponta o interesse pela psicologia a partir da realização das entrevistas desta pesquisa e considera a importância do professor poder ter espaço para tratar de seus problemas pessoais:

Eu acho assim, que você ter um [espaço] coletivo pra expor aquilo que você quer, em que você pode ajudar, explicar no que você pode ajudar, em que tipos de casos você pode ajudar. Aí a gente levanta os problemas e aí faz particular, faz assim individualmente, com o professor com aquele caso. E se um caso for gritante, que for um caso que deu certo, tudo, que seja falado coletivamente, porque os outros tiram de exemplo. Porque você pode ter alguma coisa semelhante e você age então, como aquele caso deu certo, você tenta também. Se não der certo, vamos individualmente depois. Eu acho que precisam os dois momentos, tanto coletivo, quanto individual, dependendo dos problemas. Agora, não gosto de psicóloga, já te falei, nunca gostei, mas agora que eu converso com você, eu estou começando a gostar, só que, sei lá, falta dinheiro pra poder... Eu acho que eu mesma, eu, Wanda, precisaria também por tantos problemas.

Por caminhos diferentes, todos pedem a mesma coisa: ajuda. De maneira geral, a psicologia é desejada para produzir encontros em circunstâncias de total desencontro: querem encontros entre professores e alunos, entre professores e professores e entre professores e a sua profissão.

Quando falam o que esperam da psicologia (entendida como uma área que presta serviços individuais, como a medicina), também falam sobre o que esperam da pesquisadora, mesmo que esta tenha, em diversos momentos, retomado que seu papel na escola não era o de psicóloga. Querem a escuta, tanto para seus problemas profissionais, quanto pessoais. Por isso, a boa aceitação do espaço constituído ao ouvi-los falar de sua solidão, de sua impotência e de suas frustrações na escola. Querem encontros, espaços coletivos, psicólogo como parceiro, como acompanhante.

Os professores desejam soluções, inclusive para problemas que não cabem à psicologia, ou somente a ela resolver, como a pobreza de maneira ampla. Mas a psicologia pode proporcionar a escuta da pobreza: 
Eu acho que os tempos agora estão necessitando mais de psicologia, sabe? Porque eu vejo que as pessoas estão cada vez mais complicadas, as crianças, os meus adultos, eles estão cada vez com mais problemas. É falta de emprego, fica desesperado, não sabe se volta pro interior, se fica aqui em São Paulo mesmo. Não tem dinheiro, às vezes não tem dinheiro. Por exemplo, olha só: tem a festinha junina hoje. Uma aluna disse que não vinha porque não tinha dinheiro pra trazer nada. E era: "traz um prato de doce, um prato de salgado ou um refrigerante". Daí ela falou: "Não professora, refrigerante também é caro". Eu falei: "Compra aquele de um real". "Eu vou ver, eu vou ver". Então eu quero ver o que ela vai fazer. Porque, na minha idéia, eu já tinha que tirar um real, dois, da bolsa e estar dando pra ela, sabe? Eu tenho pena, eu quero tentar resolver também os problemas dos outros. Mas eu não consigo resolver problema de todo mundo. Então eu acho que aí precisava mesmo ter psicologia, estar uma psicóloga em todos os períodos, no noturno. Porque, de vez em quando, um aluno estar saindo da sala, ir conversar, sabe? Bater um papo. E até nós mesmos. Porque está cada vez mais complicada a situação de vida mesmo, fora da escola, e que traz os problemas pra dentro da escola. E tem muita influência. Então eu acho que precisa sim. Mas uma psicologia assim agradável. Porque não só aquela que diz: "Ah, pergunta, pergunta, pergunta”. Você só fala, fala, fala, e não dá solução. Que é o que mais acontece. Que ajude mesmo a solucionar, que procure um meio junto com a pessoa de ajudar naquilo [Wanda].

Mesmo que o psicólogo não possa resolver todos os problemas apontados, ele pode ouvi-los. O relato a seguir, traz mais um exemplo dos momentos em que a pesquisadora proporcionou a escuta das dificuldades do professor:

Com os problemas de indisciplina, os de aprendizagem também, que, às vezes, a criança não aprende e a gente não consegue saber por que, a não ser que seja visão, ou audição [...] Às vezes, tem problemas emocionais. Que traz lá, que o pai bebeu a noite inteira, chegou, brigou com a mãe, e a criança fica dormindo [...] Então, o bom mesmo seria uma psicóloga dentro da escola pra estar fazendo isso. O professor chegar e falar: "Olha, esse aluno está agindo de tal maneira. Será que dá para você conversar com ele? Será que dá para você ver o que está acontecendo, no que a gente pode estar ajudando, eu e você?”. Que você chega pra mim e fala assim: "Olha, o problema dele é que ele tem medo de fazer o que ele não sabe”. Que acontece muito. Você põe na lousa 
uma coisa que ele não sabe, dá sono. Ou dá dor de cabeça, ele não quer fazer. Então como é que vai resolver isso? Não é só a professora. Eu acho que a professora tem que ter uma orientação. Você chegaria pra mim, sei lá, falaria o seguinte: "Passa uma atividade diferente pra ele, até ele chegar naquela”. Eu já iria fazer o que você está falando, entendeu? E ajudar mais esse pessoal todo, as crianças mesmo, os adultos, porque com adulto não é tanto, mas tem muito problema. Tanto é que a Dona I. [inspetora de alunos da escola] me contou um caso que a moça está grávida, do filho da amiga. Ela deve ter uns vinte e cinco anos, e o menino, acho que deve ter uns dezoito. Está grávida. E não quer a criança e falou que vai largar no hospital. Pra você ver como a noite está cheio de problema também, com adultos. Eu achei uma barbaridade. Mas antes deixar no hospital. Porque ela disse que já tem uma filha de dez anos que está com o pai, e que ela não quer filhos. E a Dona I. me contou isso, e eu fico pensando, minha cabeça fica torturando aquilo, sabe? Amassando aquilo, tentando querer resolver o problema da moça que eu nem conheço, pôxa! E aí não. Se tivesse uma psicóloga, a psicóloga chama, conversa. Por que não usou a camisinha, pra começar. Ainda bem que pegou um filho, não pegou uma AIDS. Então, tem uma série de coisas. Vai largar a criança no hospital. Então, eu acho que vocês [os psicólogos] precisavam estar dentro da escola [Wanda].

Assim, ao falar sobre o que esperam da psicologia ou sobre suas demandas para ela, os professores contam essencialmente a sua situação de desamparo, solidão e sobrecarga, que só pode ser entendida se remetidos à condição da escola pública atual ${ }^{32}$. A sobrecarga, o peso, a perda de rumo e da especificidade do papel do professor - que, muitas vezes, busca até mesmo ser “um pouco psicólogo” - denotam a desconsideração por parte dos órgãos governamentais com a educação pública. Por não conseguirem resultados com seus alunos, os depoentes pedem ajuda durante todos os momentos das entrevistas. Querem suporte, socorro, apoio, respaldo, direção, orientação, encontros coletivos, reuniões grupais, horários para conversar.

O caso da inclusão é “a gota d’água” do caos vivido diariamente. A inclusão de alunos com necessidades especiais é algo absolutamente novo. Sentem-se despreparados para lidar com estes alunos e totalmente abandonados diante das novas exigências. Por isso esperam da psicologia a troca, a companhia, o encontro.

\footnotetext{
${ }^{32}$ A realidade escolar atual, apresentada pelos entrevistados, será apresentada no capítulo 7.
} 
Por outro lado, o relato do contato que tiveram com psicólogos nas unidades escolares nas quais trabalham ou por meio de encaminhamentos dos alunos com “problemas de aprendizagem e de ajustamento”, mostra a distância destes profissionais da realidade escolar e das demandas dos depoentes:

Aqui a gente teve um projeto ano passado com uma professora formada em psicopegagogia, e que ia formar uma turma especial pra trabalhar com crianças com deficiências, com dificuldades especiais e o trabalho foi frustrante, não aconteceu. Quer dizer, até ela que ficou frustrada. Então, eu não sei, eu ainda acho que são falhas na formação. E que agora eles [os alunos das classes especiais] voltaram de novo, desmembraram as salas, e essas crianças ficaram mais prejudicadas ainda do que antes, porque elas foram separadas do convívio com outras crianças. E o que me parece que agora, depois que desmembrou essa turma especial, e que elas voltaram a mesclar as outras turmas, a defasagem delas aumentou, porque as outras foram mais avante, $e$ elas ficaram pra trás. Então o que aparece hoje nas salas de aula é que essas crianças estão com uma dificuldade maior ainda que antes do trabalho. Então, deveria ter conduzido esse trabalho, ter ido até o final. Porque eu acho que piorou até. Foi frustrante pra todo mundo. Então, eu não sei o que aconteceu de errado. A gente sente que a própria professora ficou desmotivada no meio. E eu trabalhei com essa turma no laboratório e não vi muito crescimento nessa turma. Quer dizer, talvez se eles tivessem ainda juntos com outros, teriam ido melhor, não sei. Mas não resolveu, não resolveu esse projeto, e era um projeto que pensava, tinha um trabalho com o professor que era um trabalho de psicopedagogia e que ia usar dessa ferramenta pra fazer um trabalho especial com essas crianças que tinham uma certa deficiência. E não deu certo. Acabou no primeiro ano [Antônio Carlos].

Carla teve duas experiências bem distintas, o que ajuda a compreender suas necessidades para a psicologia, solicitando, como apresentado anteriormente, a presença do psicólogo junto do professor em sala de aula:

Eu já trabalhei em conjunto, discutindo caso a caso e vendo de perto. O psicólogo fazia um trabalho bem comunitário na escola, ajudava a gente a compreender um pouco mais sobre inclusão social, era muito bom, era bom você saber que você ia ter um respaldo, 
se você entrava em desespero, ficava lá meia hora te ajudava, não para estar fazendo o seu trabalho, mas para direcioná-lo. Na época tinha um caso de síndrome de Down na sala, isso foi muito legal, porque a gente pôde estudar tudo da síndrome de Down, compreender e interagir, as interferências que iriam ajudar e ver a criança evoluindo. É tão bom porque ela só fica com você, e você não sabe fazer nada e você se perde muito, aí quando você vê, o ano acabou e ela não aprendeu nada. Aí quando você tem uma pessoa te ajudando nesse sentido, não de atender a criança, mas de te orientar mesmo, você percebe que a criança evolui, aquilo é tão bom, você ganha e a criança também. Ela aprende muito [...] Eu já tive experiência com psicólogo na escola, mas ficava lendo texto, texto, texto, texto e aquilo não ajudava, entendeu?

Márcia aponta a importância do psicólogo inclusive para as dificuldades pessoais do professor. Além disso, mostra como trabalhos de pesquisa têm sido freqüentes nas unidades escolares:

Nas escolas particulares que tinha [psicóloga], eu aproveitava muito assim, tudo. Estudava tudo. Até eu lembro que teve uma orientadora nova que entrou, coordenadora pedagógica que era psicóloga e ela falava: "Se vocês tiverem algum problema...". Aí eu lembro que teve uma época que eu estava com problema pessoal sério e entrava na sala dela e fazia uma terapiazinha também [risos]. Porque influi no seu trabalho, no seu estado. E eu acho que eu aproveitei muito, tudo que tinha das psicólogas, tudo o que elas podiam me ajudar: "Ah, como é que eu ensino isso? Ah, eu estou ensinando isso desse jeito e não está funcionando, os alunos estão com dificuldade”. Então ela me dava sugestões, que você podia tentar fazer assim [...] É sabe que nesses dois últimos anos teve bastante trabalho com psicólogo aqui [na escola onde a pesquisa se realizou], inclusive tinha uma que tinha que ter vindo essa semana aqui, também para apresentar uma proposta de trabalho, eu acho que até tem bastante pessoas interessadas em fazer trabalho. Mesmo não tendo psicólogo na escola, tem vindo bastante psicólogos [...] É de pesquisa... o que era mesmo? Até fui eu que anotei, agora não vou lembrar, que ela falou... ah são três psicólogas, uma ficou de vir esta semana apresentar a proposta de trabalho... Conflitos, o tema é conflitos, ela ia esmiuçar isso, os conflitos que aparecem na escola. 
A solicitação de Maristela de que a psicologia pode trazer auto-conhecimento e melhorar as relações humanas está muito próxima de sua experiência pessoal com o psicólogo:

Então, eu fiz terapia. Quando você faz análise, você aprende, tem uma premissa ali. Você aprende a sorrir um pouco melhor, de viver a experiência junto com o outro, a sorrir com o outro, as convenções, as leis morais, as conseqüências de muita pressão do grupo no individual. E quando eu comecei a fazer esse trabalho de análise, de terapia de análise, eu não entendia como é legal você se ouvir de vez em quando, esse auto-conhecimento, essa auto-crítica. Ouvir-se nesse sentido mesmo. Não é simplesmente ouvir a minha voz. Fazer todo o trabalho de auto-crítica, de autoconhecimento e acaba refletindo em todas as questões da sua vida. Eu consegui fazer coisas muito interessantes, de auto-aceitação.

Nancy e Sandra apontam a falta de retorno dos psicólogos para os quais as crianças com “problemas de aprendizagem” são encaminhadas:

Tem muitas crianças, por exemplo, que são encaminhadas para os setores da prefeitura. Mas é muito difícil, porque, às vezes, não tem vaga. A mãe não leva, ou então ela fala que está levando e não leva, ou então quando a criança vai, consegue ir nesses lugares, às vezes, as psicólogas pedem um relatório para a gente e a gente escreve o que a gente está sentindo. Mas, também não tem muito retorno, o que você faz para a criança, o que você não faz. Eu nunca tive esse encaminhamento para psicólogo. Já tive, mandei para fonoaudiólogo. Mas a gente também não tem retorno, o que ele está fazendo. Eu sei que tem professora aí que mandou para a psicóloga, mas é muito difícil elas terem um retorno, e parece que lá é uma coisa e aqui é outra, eles fazem lá uma coisa e que você faz outra, não sei. Eu acho que não tem muita ligação [Nancy].

Esse ano, por exemplo, tem alguns alunos muito tímidos, fechados, - uns três, quatro que não se liberam, não falam não se expõem. Dois não conseguem copiar letra cursiva. Aí eu coloco a letra bastão na lousa, mesmo assim ainda tem muita dificuldade. Um deles outro dia apareceu com um laudo da APAE. APAE é físico, né? Não é psicológico. Mas aí, eu fui mostrar para a coordenadora - o laudo não - apareceu com um 
receituário. Aí, estava escrito que solicitava à escola que usasse apoio pedagógico com aquele aluno. E ficou uma incógnita. O que é que ele quis dizer com isso? Eu não sei, a coordenadora também não sabe e falou assim: "Na verdade eles tinham que falar para nós o que nós devemos fazer com esse aluno". Então eu acho que a psicologia é neste sentido. $O$ aluno vai, passa, faz uma triagem, faz um tratamento, e aí? $O$ que isso vai mudar na escola? [...] No ano passado, ele não é mais aluno meu, mas tem o D. O D. começou o ano passado com o tratamento psicológico com a psicóloga. Aí é aquela coisa, vai uma vez por semana, todo sábado, às vezes, a psicóloga entrou em férias, aí foi aquele tratamento. Esse ano eu soube que veio o laudo. Ele é hiperativo, tem déficit de atenção. Mas o que fazer com ele? Ninguém sabe [Sandra].

Sandra destaca a distância das ações dos psicólogos da escola. Vislumbra uma outra presença da psicologia na educação, mesmo que logo retome uma versão da presença clínica:

Porque a distância da escola com o psicólogo é muito grande. Eu não tenho contato com eles. Nem com a mãe do D. eu tive. Não é nem falta de vontade. Teve uma época que eu tive um aluno com problema mental e eu escrevi pro psicólogo - não sei se era psicólogo que ele passava, se era uma clínica, não lembro o que era - o que eu achava dele. Então uma professora falou assim: "Ó, cuidado com aquilo que você escreve. Porque é muito comprometedor você falar uma coisa de um aluno que você não tem base teórica pra falar aquilo". Então, o professor age muito no "eu acho que é isso". Ninguém tem certeza se é isso. Eu acredito que o D. tenha déficit de atenção. Aí foi comprovado realmente, até o psicólogo chegou nessa conclusão. Então a gente fica satisfeita de saber que realmente tinha uma noção da coisa.

A história do contato com os psicólogos determina, em alguns casos, as definições de psicologia, bem como as demandas a ela apresentadas. Essencialmente desejam a presença do psicólogo, dando retorno sobre suas solicitações. Contudo, suas demandas estão muito longe de serem atendidas e suas experiências são, geralmente, frustrantes. 
A relação que os entrevistados estabeleceram com a psicologia, apresentada ao longo deste capítulo, demonstra que possuem duas concepções sobre ela: a) a psicologia como base para as relações humanas, para harmonizar conflitos, para desarmar conflitos e não para explicitá-los e b) a psicologia como diagnóstico.

Como dito anteriormente, quando respondem à pergunta: “o que é psicologia para você?”, parecem não saber defini-la, mas ao falarem sobre sua presença em seu trabalho pedagógico ou sobre as demandas e necessidades que a psicologia poderia atender, mostram que aprenderam muito sobre esta ciência. Ao definir psicologia a partir das questões que ela, em sua opinião, poderia “resolver”, apresentam a apropriação de um meio - instrumento - para atingir fins pedagógicos. Por isso, a insistência da presença da psicologia no dia-a-dia, na sala de aula, na escola: para solucionar problemas de forma imediata.

A psicologia ensinada nos cursos de formação, que consideram distante da solução imediata dos conflitos escolares, leva os entrevistados a não desejar aprender psicologia, mas a querer a parceria dos psicólogos, de modo a resolver os problemas práticos com que se defrontam num cotidiano escolar difícil. 


\title{
CAPÍTULO V - O CAMINHO PERCORRIDO: da formação profissional à experiência de vida
}

\author{
Esta profissão de professora a gente já tem uma \\ idéia porque nós somos alunos. E eu acho que a \\ gente acaba sendo o mesmo professor que você \\ teve como imagem lá. Não tem muita mudança \\ [Sandra].
}

Avaliar a presença da psicologia na formação remete à avaliação da formação em geral. Ao relatar o período em que estudaram para ser professores, os depoentes descrevem os conteúdos aprendidos - quando é possível se lembrar deles - queixam-se da distância entre os cursos formadores e a realidade escolar, fazem críticas e apresentam propostas relevantes para a presença da psicologia em seu cotidiano e em sua formação.

Ao falar da formação em psicologia, de maneira geral, verifica-se que os entrevistados pouco se lembram do que estudaram e quase todos mencionaram os mesmos autores e teorias: Piaget, Vigotski, Wallon e Freud, além de Emília Ferreiro, como representante do construtivismo. Paulo Freire e Jung também são citados.

Antônio Carlos, que teve sua formação em Engenharia e fez um curso de complementação pedagógica com conteúdos de psicologia, afirma:

Se você me falar do material que eu manipulei de psicologia eu até já não me lembro mais [...] Não me lembro, aliás, pra ser sincero, até de alguma coisa específica [...] Eram textos, eram algumas apostilas, e olha, na área de Psicologia era bem pouco, porque a gente estava mais ligado mesmo a propostas pedagógicas. Tinha Vigotski, que falava alguma coisa remota, mas era mais do social, do político e social do que o psicológico mesmo. Então era muito pobre. Lembro que era um curso que era só de 
uma vez por semana. Pra você ter uma idéia, foi um ano só e uma vez por semana, era só aos sábados, e durante um ano. Então foi muito pobre de psicologia mesmo [...] Porque a gente não tinha uma avaliação, porque o que a gente tinha depois do final do ano, dos dois semestres, que a gente fez curso, eram monografias. Por incrível que pareça as monografias não estavam nem vinculadas à psicologia voltada para educação ou à psicologia em si mesma. Então a nossa avaliação era em cima das monografias e as monografias eram voltadas pra parte pedagógica específica, então, nem existia nenhum comprometimento dos alunos que faziam o curso naquele momento se desenvolver com a psicologia [...] A gente estudava todas as teorias da pedagogia. Começando com a do Piaget, passando por Wallon, o Vigotski, Ana Emília [sic], Paulo Freire. E assim sempre algumas coisas pinceladas que a gente passava, mesmo na visão do Paulo Freire, que, às vezes, algumas pessoas falam que tinha alguma coisa, mas é sempre no social. Na parte específica de psicologia, talvez também não tinha essa formação, e no trabalho dele não aparece isso com força. Então a gente estudou mais os teóricos, mas sempre voltados mais pra prática pedagógica em si do que pra psicologia aplicada nessas práticas, entendeu? Então, realmente... Olha, eu tenho, eu até procurei me esforçar pra lembrar depois e não consegui lembrar de nada, absolutamente nada de algum psicólogo, alguma teoria da psicologia voltada pra educação, de algum nome notável, nada me lembro daquela época.

Sandra, apesar de ter tido mais contato, durante a sua formação, com a psicologia, uma vez que fez magistério e participou do $\mathrm{PEC}^{33}$, apresenta dúvidas sobre os autores que estudou:

Nossa, magistério não me lembro de nada de teoria. Lembro agora do PEC que é mais recente. Mas, como eu já te disse da outra vez, eu fico em dúvida: "Quem é psicólogo, quem é biólogo", eu não sei. A gente estuda Freud, estuda Vigotski, mas o que cada um é? Quem é o psicólogo mesmo?

Nancy, além dos autores que também aparecem no depoimento dos outros entrevistados, relata outros conteúdos, que considera psicológicos, com que teve contato:

\footnotetext{
${ }^{33}$ Programa de Educação Continuada, oferecido pela prefeitura da cidade de São Paulo, em parceria com a Universidade de São Paulo (USP).
} 
Emília Ferreiro, o Paulo Freire, tem o Vigotski, uma infinidade aí que agora eu não estou lembrando, mas se eu pegar algum livro, eu vou falar: "Não, esse daqui eu já li, eu já vi”. Muito referente à educação. Mas tem outros livros que não são propriamente psicologia, mas se referem a relacionamentos humanos. Por exemplo, eu li um livro que se chama "Eu não sou doente", da síndrome da mãe que transfere os problemas dela, que ela gostaria de ter afetividade pra ela, ela não conseguiu de pequena ter, ela transferiu tudo pra filha e colocava a filha como doente, e a menina sofreu a vida inteira, fazendo operações desnecessárias. Então pra ver como que é o relacionamento, às vezes, de uma pessoa doentia. Influi muito em outra coitada que estava nas mãos dela. Então eu sempre procuro ler livros de relacionamento humano, eu acho importante. Mesmo que não esteja escrito "psicologia”, mas trata de relações humanas. Por exemplo, no Big Brother, que todo mundo mete o pau, eu gostava de ver pra ver como as pessoas se relacionam. Se elas são falsas, se elas estão fazendo um jogo por trás, ou se elas estão sendo sinceras, e isso me atrai [...] Assim, pra te dizer a verdade, a maioria dos livros é tudo por conta mesmo, porque eu gosto. Porque na escola a gente lê muita coisa mais relacionada à psicologia de aprendizagem, Emília Ferreiro e Piaget, também construtivismo, toda essa parte. Mas fora isso eu procuro ler, eu fico tirando livro da biblioteca, mas quando eu vou ver é relacionamento humano, sabe? Eu acho importante, me atrai.

Carla, a professora que teve o contato mais recente com a psicologia, porque se formou em Pedagogia há um ano, repete a mesma lista de autores que todos os outros depoentes:

Eu fiz CEFAM (Centro de Formação e Aperfeiçoamento no Magistério), e depois eu fiz faculdade, na FTS (Faculdade Taboão da Serra). Eu vi [psicologia] tanto em um como no outro, eu achei que na faculdade é mais aprofundado. Pelo que eu lembro era: Psicologia da Educação, História da Psicologia, Psicologia I, II, III e IV. E eu achei que em ambos os lugares era uma coisa mais voltada a crianças de uma certa faixa etária, e não tinha estudos mais importantes, de maior peso, que ficou devendo [...] Em ambos os lugares a gente estudou muito Piaget, Vigotski, Wallon, Freud, e a partir daí começamos a fazer umas discussões a respeito do que a gente achava, e fazendo na teoria, o que é que dava certo, o que não dava, fizemos alguns estudos teóricos. 
A professora descreve, de maneira mais detalhada, como as disciplinas de psicologia estavam organizadas no curso de Pedagogia:

Havia uma preocupação de recordar a matéria dada no semestre anterior e o tempo que você gastava lembrando tudo que você tinha estudado era uma coisa absurda. E apesar de tudo, de tantas milhões de vezes eu ter escutado, tem coisas que, às vezes, você se pega pensando que não é bem aquilo. Você vai lá, revisa seus estudos, não, está errado, é de outro jeito, aí você começa a fazer do outro jeito [...] Mudava de professor, mas todos eles sempre retomavam Piaget, Vigotski, Wallon e Freud.

Márcia estudou psicologia tanto na graduação em Pedagogia quanto no curso de Psicopedagogia e relata:

Na faculdade, eu lembro que eu fiz "Psicologia da Infância", e depois "Psicologia da Adolescência”. O resto eu não lembro. Sinceramente não estou muito bem lembrada. Os autores eu não lembro. Só Freud. Acho que a gente estudou bastante Freud na faculdade. Eu lembro que teve uma parte grande da infância, e depois até uma parte grande de "Psicologia da Adolescência", que eu até me identifiquei muito porque eu tinha dezessete anos, então era tudo que estava acontecendo comigo. Então tinha vários textos, eu não me lembro muito de autores, este tipo de coisa. Então tinha "Psicologia da Infância I", "Psicologia da Infância II", eu acho que era assim. Da adolescência também. Daí quando eu terminei a faculdade, eu fiz "Orientação Educacional", também tinha uma parte de "Orientação Vocacional”, daí a gente fez mais pesquisas de campo, para estudar as profissões e depois eu fiz a Psicopedagogia. Daí tinha bastante coisa, e aí eu fiquei apaixonada por Jung. E eu adoro. Eu não sei se é porque a professora que dava a disciplina, que chamava "A evolução cognitiva e afetiva", e ela é apaixonada por Jung. Então ela passava essa paixão, sabe? Ela falava de um jeito e eu fiquei completamente apaixonada. Comprei um monte de livro do Jung, e a minha monografia, a base teórica foi Jung. Ainda mais que a minha monografia foi sobre arte, e eu acho que tem tudo a ver com Jung. Então coloquei como a base teórica. Tive psicanálise, eu lembro que tive psicanálise na faculdade, mas não ficou na minha memória muita coisa não. Na Psicopedagogia a gente estudou - apesar de ser segundo 
semestre só - acho que ficou mais gravado. Acho que eu aprendi melhor. Vi linguagem não verbal, técnicas corporais expressivas, distúrbios da aprendizagem, na faculdade também teve, na Psicopedagogia, lógico que mais. De autores, é engraçado, que eu só lembro Freud e Jung.

Durante o curso de Psicopedagogia, a depoente, por três anos, cursou disciplinas voltadas à psicologia aplicada à educação, embora relate não se lembrar muito bem dos autores ou das teorias. Com Maristela, a falta de memória também ocorre e ela cursou apenas um semestre de psicologia. Há, em seu relato, uma crítica sobre a maneira como a disciplina Psicologia Educacional, vista na sua formação em História, estava organizada. Aqui, a professora relaciona a falta de lembrança com a falta de compromisso da docente responsável pela disciplina:

Olha, infelizmente a minha professora [de Psicologia Educacional] ela tinha um método... Acho que ela não tinha método nenhum. Nós usávamos um livro enorme e também não me inspirava grande confiança. E olha, eu me lembro muito dessa época de estudante e tudo, mas aula de Psicologia Educacional eu não me lembro. Você pressupõe o quê? Acho que a professora era... Não sei, acho que ela batia papo na sala de aula. Nem que fosse aquela coisa assim mais distante: "Vamos fazer seminários, vamos apresentar para o grupo, o grupo apresenta para a sala", eu acho isso uma enganação, uma enrolação por parte do professor. Mas eu não me lembro de nada substancial, que tenha me marcado, que tenha tido um peso na minha formação profissional. Não me lembro [...] "Psicologia Educacional" chamava o livro. Eu tenho até hoje. É um livro até que interessante, mas muito conceitual [...] Mas, eu acho que nesse semestre pouco me lembro, viu? Eu acho que nada. De uma forma sistematizada, séria. Mas não tenho nem apostila pra você ter uma idéia. Porque às vezes tem, além daquele método desonesto, “vamos fazer grupo, seminários”, tem aquele outro também que enche você de apostila e manda você ler. Nem isso... Trágico.

O relato de Maristela mostra a presença da crítica à formação. Isto ocorre em todos os depoimentos. Mas, o mais freqüente, quando falam sobre os conteúdos aprendidos de cada autor citado, é a desarticulação das falas e a imprecisão conceitual: 
Sobre as teorias de construção, até de um tipo que o Piaget tanto fala, que ele tenta entender o pensamento, ele tenta criar um caminho lógico para tentar decifrar o que a criança pensa durante a fase de aprendizagem. Mas o que ficou marcado pra mim mesmo do Piaget, tanto do Piaget como de todos eles, foi a visão política que existia por trás, qual era o processo que alguns eram mais conservadores e outros menos conservadores. Que o Piaget de todos era o mais conservador, mas que não tinha nenhum trabalho, eu não sei se social que eu poderia falar, quando a gente fala um pouquinho da Teberovsky, ou fala do Paulo Freire, que tinha visões aí que mesclavam outros interesses políticos no meio, de movimentos, mas não de psicologia. Até do Paulo Freire mesmo, não consigo, e principalmente do Piaget. $\mathrm{O}$ que eu consigo lembrar do Piaget, bem remotamente mesmo, é de algumas fases que ele fala, que ele não aborda nem de perto o construtivismo do Paulo Freire, da teoria construtivista do Paulo Freire, mas ele tenta colocar aquela coisa da massificação, assim, da influência do meio na criança, que Piaget fala um pouquinho, que depois do Paulo Freire, de uma outra abordagem, também fala. Mas eu tento pensar assim, da inserção, que o meio interfere no processo, então que a criança também tinha isso, me lembro um pouquinho do Piaget falando nessas coisas, não consigo pensar no Piaget, quando ele falava da psicologia em si mesma, da criança, como avaliar isso. Se falou, ficou um branco na minha cabeça, porque eu não consigo lembrar, não consigo [Antônio Carlos].

Piaget, Wallon e Vigotski. Vigotski eu acho que eu consigo perceber bem onde que eu uso. Por causa dos conceitos de Zona de Desenvolvimento Proximal, que o mais avançado ajuda o que sabe menos, que você tem que fazer as duplas por proximidade. Às vezes quando a gente faz dupla, se você coloca uma criança que sabe muito, com uma criança que não sabe nada, também não dá certo. Você tem que saber dosar. E, às vezes, as crianças perdem muito a paciência para ensinar os outros. Então, eu já escolho os que têm mais paciência. Wallon, eu já não consigo perceber muito onde que eu uso, mais na parte emocional, acho. Mas, eu acho que eu consigo vislumbrar melhor o Vigotski, que eu estudei bastante tempo [Márcia].

A descrição de conteúdos é imprecisa e superficial. Os depoentes conseguem citar autores e no máximo, lembram-se de "frases feitas": Vigotski e a zona de 
desenvolvimento proximal; Piaget e as fases de desenvolvimento cognitivo; Freud e a sexualidade; Emília Ferreiro e o construtivismo.

Os conteúdos de psicologia que se tornaram marcantes durante a formação ou que são facilmente lembrados, em alguns casos, referem-se às famosas "experiências do rato” ou a histórias fantásticas, que não possuem vínculo com a realidade:

Ah, o que a gente via era Freud. Aquela experiência do rato. Piaget, algumas coisas assim. Não lembro muita coisa não [Wanda].

Desde o início no magistério eu tive a "Psicologia da Educação", "Biologia da Educação", tudo referente à educação. E eu me lembro muito bem de uma aula da professora de psicologia no magistério, que ela deu o condicionamento de Pavlov, aquilo me marcou muito, porque eu nunca tinha ouvido falar nada de psicologia, porque eu nunca tinha estudado psicologia na vida. E aquela explicação de condicionamento lá do ratinho. Nossa, eu me lembro como se fosse a aula agora. E olha que já faz muito tempo que eu fiz magistério. E a partir daí eu fui tentando ver porque existe o condicionamento, porque não existe condicionamento. Eu comecei a tentar ler e me inteirar mais de psicologia. E depois eu fui pra Pedagogia, antes de ir pra Pedagogia eu queria ir pra Psicologia, mas acabei indo pra Pedagogia e sempre as aulas de psicologia me interessavam. Na faculdade eu via o mundo mágico da criança, também me marcou muito, e outras coisas que fui lendo depois da Psicopedagogia quando eu fiz. Também eu lembro daqueles questionários de anamnese que a professora ensinava pra gente. Então alguns pontos ficaram mais claros, outros mais nebulosos, mas algumas coisas marcantes eu lembro. Piaget, eu ouvi pela primeira vez Piaget, também eu achei super-interessante, não entendi nada no começo - o que era acomodação, assimilação, essa coisa toda - e eu tive que buscar sozinha [Nancy].

O que mais me marcou foi a história do menino lobo, que aquilo foi pra mim extraordinário, não tinha idéia. Me marcou também a do menino que o enclausuraram e lá, trancado, sozinho, num quarto quietinho. Jogavam comida por debaixo da porta, um negócio assim, para ver o que ele aprendia. A estória da campainha, se toda vez que tocar a campainha você lamber um limão, toda vez que você escutar a campainha tocando você lembra do gosto azedo do limão [Carla]. 
Apesar de Carla ter apontado que, durante seis semestres somente no curso de Pedagogia, teve contato com disciplinas de psicologia, enfatizando que sempre os mesmos autores se repetiam - Vigotski, Wallon, Piaget e Freud - suas lembranças limitam-se a casos fantásticos e imprecisos. Em seu depoimento não há menção a conteúdos específicos de qualquer um desses autores.

O contato dos depoentes com a psicologia geralmente ocorreu durante a formação inicial ou em cursos de Psicopedagogia, como é o caso de Márcia e Nancy. Poucos foram os exemplos de cursos de aperfeiçoamento ou reciclagem que contemplassem conteúdos de psicologia. Wanda fala sobre palestras oferecidas pela prefeitura de São Paulo:

De psicologia mesmo, só palestras. Assim, tipo com o Içami [Tiba]. Palestras. É com psicólogos, que vêm na escola, que a gente vai, que a prefeitura programa. Ah, agora, curso mesmo de psicologia, não. Mais de alfabetização [...] Ah, problemas de pais com filhos, também tinha uma vez que eu fiz, logo no começo, quando eu me efetivei na prefeitura, uns livros que a gente lia, uns livrinhos fininhos, por exemplo: criança de dois anos. Nós líamos, e discutíamos com a psicóloga. Sobre a criança de dois anos. $\boldsymbol{E}$ aí a gente foi até a idade que eu estava dando aula, que era de sete anos, era primeirasérie. Depois também saí desta escola. Essa escola levava mais a sério. Todas tinham o livrinho, todas liam. Então, porque a criança não quer largar a chupeta, tudo. Desde o comecinho.

Nancy conta as experiências de $\mathrm{JEI}^{34}$, nas quais os mesmos autores vistos durante a formação inicial se repetem:

A coordenadora, principalmente a que saiu, ela falava muito da Telma Vaz [sic], do construtivismo, e do Piaget, e das fases da criança, e das hipóteses lá da Emília Ferreiro, da hipótese que ela levanta sobre a escrita.

\footnotetext{
${ }^{34}$ Jornada Especial Integral, horário de trabalho pedagógico dos docentes na escola.
} 
Sandra mostra que, mesmo em cursos de seu interesse, a dificuldade para lembrar-se do conteúdo permanece:

Uma vez eu fiz um curso que é evangélico, mas tinha o título "Psicologia da Criança". Então o que mostrava lá: a criança de tal idade - como é que ela aprende - aprende, não - como é que ela se relaciona, o que ela faz naquela idade. Não me lembro de nada, de mais nada disso daí. Talvez se eu me aprofundasse, ajudaria os meus alunos a entender melhor algumas coisas. Ou aprender melhor as matérias, os conteúdos, não sei. Mas, é aquilo que eu já te falei: sou muito preguiçosa.

Nesta fala, a professora atribui a falta de lembranças à sua preguiça. No entanto, em outro momento, contando sobre como o PEC estava estruturado, apresenta novos elementos que podem contribuir para o entendimento da constante falta de lembrança dos cursos que os depoentes tiveram contato:

Nós tínhamos uma tutora, e o material, uma apostila já enviada pelo próprio PEC, enorme. Porque, no começo do curso você não tem noção do quanto. Uma das apostilas chegou a mil e setecentas páginas. Então é muito assunto para dois anos de curso. E aí a tutora tinha um cronograma a seguir. Tinha que ler tal texto no dia tal, tal texto no outro dia. Quer dizer, se o primeiro texto não ficou bem lido, não ficou resolvido, ou então o grupo discutiu muito e não andou, ele ia continuar no dia seguinte, lógico, a nossa tutora tinha essa autonomia de continuar, mas daí emperrava o outro texto que tinha que ler no outro dia. Então nós estávamos sempre atrasados, muito atrasados. Quando chegava perto da prova, ela ficava preocupada, porque tinha muita coisa que a gente viu por cima, tinha coisas que nós não chegamos a ver, principalmente quando chegava em educação infantil, que é pré-escola, ficava para o final. E como não é a minha área, não era área de muitas professoras, preocupava, porque a gente não sabia muito bem o que ia cair na prova. E prova tradicional, com resposta, uma resposta esperada pelo PEC, então você não podia dar sua opinião, só ficar na sua opinião, não podia. Você tinha que se basear no texto, nos autores. E era muita coisa para estudar na hora da prova. Então era uma pena por causa disso. Porque o curso, até que pra mim pelo menos foi bom. Vi muita coisa que eu totalmente desconhecia. Então todos 
esses autores, apesar da gente estudar em JEI, Vigotski, Wallon, Piaget, Freud, Emília

Ferreiro, e outros aí. Mas o pessoal comenta nas escolas como se todo mundo soubesse quem é, o que fez, o que ele defendia, e na verdade não é assim [...] Foi esse o curso. Aos trancos e barrancos, muita ajuda da professora, da tutora, graças a Deus era boa, e entendia o lado da gente, estar cansada, da má formação, da falta de informação também, e ajudou bastante.

A falta de organização dos cursos oferecidos - não só os de psicologia - o atropelo de conteúdos, o número de autores citados nos depoimentos, a referência a teorias, os exemplos desarticulados de conteúdos de psicologia e a imprecisão conceitual podem justificar o número de vezes que cada depoente disse não se lembrar da sua formação. Tal fato ocorreu tanto com aqueles que se formaram há mais de trinta anos quanto com aqueles que finalizaram sua formação inicial ou complementar há menos de um ano. Independentemente do tempo de magistério e de formação, os depoentes tiveram contato com os mesmos autores e da mesma forma: um amontoado de teorias desconexas, expostas como em uma vitrine.

Avaliam, de maneira geral, que tiveram uma formação superficial em psicologia, mesmo naqueles casos em que vários semestres dos cursos de formação foram dedicados a esta matéria. Além disso, falam da distância entre a psicologia ensinada e a realidade educacional, isto é, queixam-se da dificuldade de relacionar os conteúdos aprendidos com a prática pedagógica:

Mesmo porque a gente não teve nenhum trabalho com psicólogo, nenhum psicopedagogo [durante o curso de complementação pedagógica]. Não tinha isso. Não eram pedagogos que estavam lá dando aula, não era uma psicóloga ou uma psicopedagoga, entendeu? Então eu acho que não houve uma ênfase nessa formação pra que tivesse destaque na área da psicologia. Tanto é que não marcou nada, não ficou nada. Se realmente eu tivesse percebido - que eu já tinha uma prática de mais que quinze anos - se alguma coisa tivesse na minha formação que tivesse aparecido na 
área, que tivesse me ajudado, eu teria incorporado, e nada tem nessa área. Eu não utilizo nada da área de psicopedagogia ${ }^{35}$ [Antônio Carlos].

Quando descrevem os cursos de formação e os avaliam, falam de uma formação precária, que inclui tanto a formação em psicologia como a formação em geral.

Há queixas, como é o caso de Carla, contra a estrutura da disciplina de psicologia e do próprio curso de Pedagogia que não permite ao aluno aprofundar-se:

Acho que você não tira muito proveito do que é estudado, eu acho que é mal direcionado. Mesmo porque na prova é o que o autor fala, não é a tua opinião, então é meio complicado, você não tem a oportunidade de discutir em cima da teoria pra valer uma boa nota pra você. Pra valer uma boa nota pra você, só se você decorou o que ele escreveu. E são textos bem difíceis de serem lidos, é uma coisa que você tinha que estudar com mais aprofundamento, com mais tempo, com mais calma, e na faculdade é impossível fazer isso, é impossível mesmo.

Já Márcia comenta a dificuldade de relacionar os conteúdos vistos durante a sua formação com as demandas surgidas em seu dia-a-dia escolar, mesmo quando eles despertaram seu interesse:

Eu acho que talvez na faculdade eu não tive uma afinidade de estudar o que eu estudei. Eu lia e não entrava na cabeça. Eu acho que era uma coisa muito distante pra mim. Sei lá. Quando comecei a estudar a "Psicologia da Adolescência", eu lembro que eu me identifiquei, porque eu era adolescente. Então tudo que as pessoas falavam, o que os autores falavam, eu falava: "Eu estou exatamente nesse momento”. Então, eu não sei, eu só lembro dessa coisa da infância e da adolescência. Eu vi várias outras, mas não ficou na minha cabeça. Não ficou gravado. Na Psicopedagogia, como é uma coisa que eu fui atrás, acho que já tinha mais experiência de trabalho e tudo, eu valorizei mais. Por exemplo, eu estava estudando Freud, da fase oral, anal, e eu lembro que eu tinha uma aula na PUC ${ }^{36}$, no segundo ano que eu entrei na escola, tinha um

\footnotetext{
${ }^{35}$ Vale ressaltar que, no capítulo anterior, outro trecho do depoimento do mesmo professor foi destacado por afirmar que não utilizava conhecimentos da psicologia em seu trabalho pedagógico, embora, tenha sido apontado que, em muitos casos, os depoentes fazem uso de termos psicológicos para explicar o que acontece com seus alunos que não aprendem, mesmo que não se dêem conta disso.

${ }^{36}$ Pontifícia Universidade Católica de São Paulo.
} 
aluno que ele entrava na aula chorando, ele chutava tudo, era agressivo, ele saía correndo e eu tive que fechar a porta com chave pra ele não sair. E aí uma vez eu chamei a mãe pra conversar, e ela passou muito tempo internada, quando ele era pequenininho. Aí, eu estava estudando Freud e fiquei refletindo: ele estava na fase tal, e a mãe dele internada. Ele se sentiu culpado porque ele queria ter a mãe perto. E a mãe ficou muito tempo internada. E aí eu falei: "Vixi... Calma, não é tão drástico assim". Ah, mas mesmo que fosse isso mesmo que tivesse acontecido, como Freud fala, o que eu podia fazer? Eu não sabia como intervir.

Dessa forma, quando indagados sobre como avaliam a formação específica em psicologia, há consenso:

Acho que de zero a dez... cinco. É um ramo que eu gostaria de estudar mais, que se fosse bem explorado, muitos dos problemas seriam resolvidos facilmente [...] Quando você pensa no total, você pensa no geral, você acaba vendo que tem coisas que te faltam estudar, tem coisas que fariam diferença se você estudasse [Carla].

Ah... elementar. Não fiz curso de Psicologia, fiz a Psicopedagogia, que foi também básica, não teve nenhum aprofundamento como se tivesse feito uma faculdade. Então ela foi básica, elementar. Eu sei pouco de psicologia, não sei muita coisa [...] A formação em geral é deficitária. Eu acho que para quem faz magistério e Pedagogia, nossa, eu acho que a formação devia ser muito... a grade curricular deveria ser muito voltada para esta parte de relacionamento, sabe? Devia ter psicopedagogia dentro da Pedagogia [Nancy].

Eu acho que psicologia, a minha foi bem pouquinha, mas também não acho que tenha que ter uma matéria assim tão abrangente [...] Então não tem como exigir do professor um aprofundamento na psicologia, porque a área dele é a pedagogia. Ele tem uma noção do que é psicologia, o que eu acho importante [Sandra].

No relato de Sandra, acima, existe uma crítica à tentativa de tornar o professor um especialista em psicologia. A depoente continua: 
Eu acho que psicologia, por que existe psicologia? Pra você ter uma noção do todo. Da criança como um todo. Das fases de desenvolvimento psicológico, crescimento. Então você tem uma noção do todo. Mas que aqui não vai te ajudar, no dia-a-dia da escola, não é a questão de ser pessimista ou não, mas eu não vejo. A não ser que você fizesse um aprofundamento. Tivesse curso de formação permanente de psicologia, e que suas dificuldades fossem surgindo $\boldsymbol{e}$ você fosse sanando. Falasse assim: "Não, mas é assim...”, “Ah, aconteceu isso”, “Não, mas isso aconteceu porque pode ter acontecido isso, isso e isso". Então aquelas coisas fossem sendo sanadas, discutidas, analisadas na sua formação, diária ou semanária, ou mensal, sei lá, aí sim valeria a pena.

Parece que o aprofundamento a que se refere a depoente diz respeito à vinculação da psicologia à prática, à realidade escolar. Como se as aulas de psicologia, durante a formação, não tivessem dado os elementos necessários para o professor desenvolver o seu trabalho, para lidar com o cotidiano. Não ser aprofundada significa que a formação não instrumentou a prática, não estabeleceu uma relação imediata com ela. Neste sentido, a principal queixa dos depoentes quando falam da formação tanto em psicologia como da formação em geral refere-se à falta de aplicabilidade. A psicologia poderia contribuir com o professor - e não com a sua formação - se estivesse presente, por exemplo, por meio do psicólogo, no cotidiano escolar. Sandra quer soluções e não cursos:

Exigir dos cursos de formação que dê base concreta não vai dar certo. Teria que ser muito tempo, aí o professor teria que se especializar nessa área, mesmo assim acho que não dá resultado. Porque se o psicólogo atende um a um, como é que nós vamos dar o resultado com trinta e cacetada na sala de aula?

Carla compartilha da mesma visão de Sandra de que os cursos de formação não têm vínculo com o cotidiano escolar:

Eu acho que o problema é assim, o estudo que eu tive ele foi bom porque se você partir do pressuposto que você tem que ter uma base, realmente eles me deram uma base boa que não tem ligação com a realidade dos problemas educacionais, mas não perde o seu mérito. 
Já Maristela avalia que a presença da psicologia na formação do professor - de forma diferenciada da que teve contato - poderia ajudá-lo a desenvolver um trabalho pedagógico mais sistematizado, no que se refere à possibilidade de melhoria das relações humanas:

Se a psicologia fosse melhor considerada nos currículos de graduação, de pósgraduação, ao menos nessas profissões que lidam mais com o ser humano mesmo, em sua complexidade toda, eu acho que as relações seriam, não digo mais harmoniosas, mas talvez um pouco mais claras. Talvez não fizesse um trabalho tão amador na sala de aula, se a psicologia estivesse mais presente. Enquanto método mesmo, método significa caminho.

Antônio Carlos queixa-se da falta de contato com a psicologia-psicopedagogia, que ele não diferencia:

Eu acho que a formação passa até por cursos, ou por dinâmicas de grupo, não sei. Que o professor tivesse acesso às informações que já existem da psicopedagogia no trabalho com as crianças, ou da escola. O que dá certo, o que deu certo e o que não, o que deu errado. Eu não tenho esses parâmetros, essas informações. A psicopedagogia tem ajudado, e no que não tem conseguido ajudar? Eu não tenho isso. E tenho certeza que deve ter ajudado muito, em muita coisa, não tenho dúvida nenhuma. Eu não tenho acesso a essas informações. Eu acho que deveria ter curso até pro professor ter contato com essas informações, qual é a evolução da psicopedagogia dentro do trabalho do professor, porque eu não consigo avaliar do nada. Não dá pra fazer uma avaliação do nada. Então eu preciso ter acesso a essas informações pra poder avaliar, até pra eu aplicar essa teoria no meu trabalho. Então eu acho que a formação passa por algum curso sim, ou por alguma dinâmica, não sei.

Aqui aparece novamente a necessidade de aplicabilidade da psicologia no contexto escolar. O desejo não é o de uma formação apenas com cursos; o docente fala em dinâmicas de grupo, contato com psicólogos. Esta mesma necessidade é sentida por outros professores, como será visto mais detalhadamente ao final deste capítulo. 
Além de relatarem as lembranças - ou a falta delas - que possuem das disciplinas de psicologia e queixarem-se sobre a ausência de aplicabilidade do que aprenderam, os depoentes descrevem os estágios realizados, ao mesmo tempo em que avaliam sua formação em geral. Para Carla, os estágios estão muito aquém das necessidades dos estudantes:

Estágio é um negócio muito complicado. Na maioria dos estágios você não faz o que você deveria fazer. E eu acho que é papel da faculdade garantir que você faça aquilo que você deveria fazer. Só que no estágio, você não tem como fazer isso, você não tem como obrigar um professor a permitir que você dê uma aula, por exemplo. Você mal consegue entrar na sala dele, sentar lá no fundo... Você já não pode entrar com papel nenhum, porque tudo o que você anota o camarada vem ver se você está anotando alguma coisa dele [...] Eu acho que você deveria ter um grupo na faculdade que você pudesse fazer isso. Ou que fosse um reforço escolar, a criança tivesse freqüência na escola e tivesse fazendo um reforço, alguma coisa assim, que a gente pudesse lidar com essa criança, frente a frente, tivesse autonomia pra fazer projeto e pra aplicar o projeto e ver como que a criança reage. Eu acho que isso faria a diferença.

Márcia apresenta opinião semelhante à de Carla:

Porque os estágios que eu fiz na graduação são aqueles estágios de observação, de você ficar só observando as aulas. Eu cumpri todas as horas. Eu fiz lá, todas as horinhas. Eu fiz em escola estadual, escola da prefeitura, tudo, mas não me ajudou, sabe? E o de Orientação Educacional que eu fiz o estágio, eu lembro que eu fazia coisas que não tinha nada a ver com a proposta. Então, a biblioteca da escola, na época estava reformando, eu arrumei toda a biblioteca. Fiz todo o tombamento dos livros, até pregar prateleira eu fiz. Aí eu e a minha amiga, pra cumprir as horas, a gente se submetia, senão a orientadora não ia assinar. Mas eu falava: "O que a gente está aprendendo aqui?". Porque até aprendi um pouco como funciona a biblioteca, mas não tinha a ver com a orientação. Por que eu estou falando? É que os estágios foram a 
coisa mais prática, mas mesmo na graduação acho que não foi legal, não gostei dos estágios, não me foram úteis. Foram só também pra cumprir, sabe? Colocar no papel e ter o diploma mesmo, porque aprender mesmo, não aprendi.

Vale ressaltar que a avaliação dos estágios também é feita a partir do critério de aplicabilidade ou de utilidade. Assim, eles se sucedem sem acrescentar conhecimentos relevantes na formação do professor, para que a instituição formadora apenas cumpra sua carga horária obrigatória e, muitas vezes, o estagiário não tem clareza nem dos objetivos da proposta a ser desenvolvida:

Então, tinha um estágio clínico no próprio prédio do $S E D E S^{37}$ que aí era atendimento clínico individual, só atendia um paciente, e tinha uns estágios institucionais. Nos institucionais a gente atendia grupos. Eu fui pro institucional, porque eu atendia com um amigo meu, que fazia Psicopedagogia comigo, e era perto da nossa casa, a gente morava próximo. Então era uma questão de facilidade mesmo. Era na favela do Jaguarés. $^{38}$. E aí a gente atendia um grupo de seis crianças. A gente fez uma triagem, ficamos no centro de juventude, fizemos uma prova e escolhemos seis e atendemos eles dois anos e pouco. Os seis que a gente triou tinham problemas de aprendizagem mesmo. Não sabiam produzir textos, estavam na terceira, quarta-série, e não sabiam ler nem sabiam escrever. $E$ aí no fundo a gente foi vendo que tinham vários problemas familiares, que a família não dava o mínimo valor pra escrita, pra leitura, pra nada. Então a gente ficou trabalhando isso. Tinha supervisão sempre, toda semana, mas aí não era toda semana o nosso caso, a gente ia revezando. E era legal porque a gente aprendia com os outros casos [...] Eu acho que a gente acabou fortalecendo um pouco a parte interna, ou afetiva deles, para eles continuarem lidando com as dificuldades. Eu não posso dizer que eles aprenderam a ler e escrever nesses dois anos. Mas porque era um trabalho uma vez por semana, que não dava conta de tudo, mas eu acho que eles tiveram mais recursos para lidar com os problemas familiares, que eles tinham pai alcoólatra. Problemas que eles gostaram de ter espaço para desabafar. Que eles falavam, conversavam muito. Que a gente estava muito presente naquele momento da vida deles. Então acho que foi um trabalho legal. Foi bom [Márcia].

\footnotetext{
${ }^{37}$ Instituto Sedes Sapientiae.

${ }^{38}$ Localizada na cidade de São Paulo.
} 
Neste caso, a professora avalia positivamente o trabalho realizado, não se dando conta dos antigos preconceitos que explicam o fracasso escolar dos alunos pobres e mesmo que os objetivos postos para o estágio não sejam atendidos. Ao final, o importante é ter contribuído com o desenvolvimento emocional das crianças, desconsiderando o objetivo inicial de alfabetização, que não é atingido. Dessa forma, momentos de críticas valiosas misturam-se a avaliações positivas de etapas da formação que também deveriam ser alvo de análise.

Os estágios, neste sentido, são apenas um dos momentos analisados pelos depoentes. Juntamente com a psicologia aprendida, eles também avaliam sua formação em geral. Wanda inicialmente considera:

A minha formação foi boa, eu não tive problemas, tanto é que eu me sentia tão compromissada com o assunto, que quando eu peguei a minha primeira classe eu chorava. Porque eu sabia que eu tinha aquele compromisso com eles, que eu tinha que fazê-los aprender, eu tinha todas as técnicas, eu tinha tudo. Então, eu acho que eu fui bem formada.

Já Márcia distingue a formação que obteve durante a graduação e aquela do curso de Psicopedagogia:

Eu acho que a graduação foi uma coisa muito teórica. E quando eu não estava trabalhando então, pra mim parecia outra dimensão, pra mim era uma coisa muito distante. Depois que eu comecei a trabalhar, começou a fazer mais sentido, mas mesmo assim sempre achei muito teórico. Acho que não tinha coisas práticas, das dificuldades que a gente tem na hora de dar aula, mesmo em relação ao conteúdo, que é uma coisa que não tem nada de conteúdo. Do que a gente vai dar em sala de aula mesmo, de: "Ah, se isso está difícil, se está fácil, o que é bom para o Fundamental I, ou o que é bom para o fundamental II?”. Não tem nada disso. Eu achava tudo muito teórico. Na Psicopedagogia eu já escolhi o curso que eu achei que era o mais prático de todos, que era o do SEDES. Então, acho que foi um pouco mais prático, a gente fazia muitas atividades, e a gente exercitava nos estágios. Então, tudo o que eu aprendia que eu achava, por exemplo, um jogo legal que alguém levava lá: "Ah, esse jogo é super legal, 
vou levar lá pro Jaguaré, esse jogo é legal, vou levar lá pro hospital”. Então, eu consegui fazer mais a ligação com a prática mesmo. Na faculdade não. Eu acho que ficou uma coisa que eu fazia pra cumprir os créditos lá que eu precisava, sabe? Mas, de falar: "Ah, eu usei...", acho que pouco. Acho que na Psicopedagogia sim. Mas mesmo assim, ainda tem coisas, por exemplo, que na Psicopedagogia eu aprendia e eu achava legal, daí na hora que eu chegava aqui - que eu mudei da escola particular pra cá - que eu falava: "Ah, tudo bem, lá na outra escola, com dez alunos, eu fazia", mas com quarenta eu não sabia como adaptar, e ainda não sei. Tem coisas que eu ainda não sei como adaptar pra quarenta alunos. Porque tudo fica difícil.

Apesar de considerar que o curso de Psicopedagogia teria sido mais "prático” do que a graduação, a depoente aponta a dificuldade de colocá-lo em prática quando se depara com quarenta alunos em sala de aula. A avaliação positiva ou negativa da formação tem como critério a aplicabilidade, a chance de "colocar em prática” ou "usar” o que aprendeu. A possibilidade de já estar lecionando durante a formação também é utilizada como critério por Sandra para avaliar o curso de magistério:

A minha formação, porque eu estava fora da escola, foi insuficiente para ser uma professora. Agora, as alunas que estavam na escola já, mas davam aula em escolinha particular, ou então davam aula numa escola numa rede pública estadual e que deixaram, porque estavam cursando o magistério. Então naquela época não se exigia o diploma como hoje para você entrar na sala de aula. Elas, eu acho que elas aproveitaram melhor. Assim como eu aproveitei o PEC, porque eu já estava na rede. Então, quando surgiu um assunto lá no PEC que a gente conhece, que é da nossa realidade, que existia muito debate. Contra, a favor, uns dando palpite totalmente diferente do outro, mas a gente sabia do que ela estava falando. Agora, no magistério, nossa, era totalmente fora da minha realidade. Eu trabalhava com contas a pagar, com escritório, na parte administrativa, não tinha nada a ver com escola. Aí as poucas vezes que eu fui fazer estágio - porque muitas vezes a pessoa até assina para você não ter que estar lá dentro fazendo estágio, você sabe disso - eu me sentia incomodada, porque eu era uma estranha naquela sala, parecia que eu estava incomodando a professora. Pouquíssimas vezes ela solicitava alguma coisa para eu ajudar, às vezes para corrigir um caderno, mas não tinha nem como corrigir o caderno. Porque eu acho 
que a correção é muito pessoal mesmo, depende do que o professor queria com aquela atividade. Então, no magistério foi muito superficial.

Sandra retoma, neste momento, a precariedade dos estágios e do próprio curso de magistério. A seguir, refere-se a um material utilizado para ensinar Matemática às crianças:

Quando eu entrei na escola, esse material dourado é super antigo também. É uma inovação, mas é antigo já. Eu não tenho nem idéia do que é esse material dourado. E você sai do magistério sem saber o que é material dourado. Muita coisa você vai aprender na sua prática. Magistério não te dá base. Não te ensina a dar uma aula, se é importante dar ou não dar um ditado.

Se o magistério é o lugar de formação por excelência, no qual os professores deveriam aprender a ser professores, como se justifica a afirmação de Sandra, acima?

$*$

Quando indagada sobre o curso de formação continuada do qual participou, inicialmente, Sandra o avalia positivamente, mas, em seguida, ressalta o atropelo e a inadequação de seus conteúdos:

Eu acho que tudo que foi dado no PEC eu aproveitei, só que tinha professores que esperavam muito mais do curso, entendeu? Muito mais do que foi dado. $\boldsymbol{O}$ que eu reclamo é que foi muito corrido mesmo e que eles queriam que nós víssemos uma matéria de quatro anos de USP ${ }^{39}$, de Pedagogia da USP em dois anos de PEC [...] Outra coisa também: eu não trabalho com educação infantil e tinha que ver a matéria da educação infantil. Apesar que a minha formação dá pra trabalhar com os dois. E o professor de educação infantil não trabalha com $E M E F^{40}$, mas tinha que ver toda a parte de EMEF também. Então, eu sentia uma dificuldade enorme quando tinha que

\footnotetext{
${ }^{39}$ Universidade de São Paulo.

${ }^{40}$ Escola Municipal de Ensino Fundamental.
} 
responder coisa de educação infantil, porque não era do meu cotidiano. E a mesma coisa da EMEF. A da educação infantil sentia uma dificuldade enorme de responder as coisas que eram da EMEF. Porque a rotina de nós duas, dessas duas instituições, são totalmente diferentes.

Márcia, ao discutir sobre sua formação, considera-a positivamente, uma vez que se formou nas melhores instituições de São Paulo. Mesmo assim, novamente ressalta a distância da formação com a realidade escolar, neste caso, referindo-se à inclusão:

Eu, por exemplo, eu acho que tenho uma boa formação, eu fiz Pedagogia na USP e fiz Psicopedagogia no SEDES, que é o melhor de São Paulo, que antes de fazer procurei em todos, e fiquei entre o do SEDES e da PUC, que eram os dois bons, mas o da PUC é mais acadêmico e eu queria uma coisa prática. O da PUC você só faz estágio no finalzinho, o SEDES você faz desde o segundo semestre. Então eu queria uma coisa mais prática fui para o SEDES. Era o mais caro, era o mais longo, que são três anos, eu falei: "Vou fazer esse porque eu quero aprender, não estou fazendo pelo diploma". Então eu acho que tenho uma boa formação, mesmo assim não dou conta. Eu acho que a formação é super importante. Nos casos de inclusão, acho que não teria professor que tivesse formação em todas, porque tem deficiente mental, visual, auditivo, físico, é difícil ter alguém que faça tudo [...] Eu não fiz nenhum, fiz "Orientação Educacional”. E então é complicado, só não tinha pegado Down, peguei esse ano, mas eu já peguei todos: tive físico, auditivo, visual, deficiência mental.

Do que Márcia deveria dar conta? O que a formação deveria dar-lhe para “dar conta”?

$*$

Um longo trecho do depoimento de Sandra, a seguir, ilustra a maneira como os cursos de formação estão organizados e a dificuldade em colocá-los em prática reclamação freqüente entre os entrevistados: 
Agora, os professores que não fizeram [o PEC], não sei se se arrependeram. Eu não me arrependi de ter feito. Foram dois anos cansativos, principalmente na parte de trabalho, eles exigiam bastante. Mas, eu não me arrependo não. $\boldsymbol{O}$ pouco que eu aprendi de conhecimento científico foi no PEC, porque o magistério, na minha época, não se preocupava com isso.

Ao se referir aos autores estudados, destaca Piaget e afirma:

Então, aí eu vi um pouquinho, também foi pincelado, não é uma coisa muito abrangente, mesmo porque o curso era muito corrido. Isso foi uma das críticas que houve na época, que muito material e pouco aprofundamento. Pouco tempo pra se discutir. Então não é uma coisa, por exemplo, no seu curso, você tem anos pra se formar psicólogo, então não é uma coisa que a gente ia conseguir ver em um mês. Então foi falado um pouquinho de cada um [de cada autor], alguma coisa eu consegui guardar, o que mais me interessava, lógico, ou aquilo que baseasse o meu trabalho ou na forma de eu trabalhar, mas pouca coisa.

Sandra fala sobre o material utilizado no PEC:

A minha tutora ela era muito crítica. Talvez isso é que tenha influenciado muito a nossa sala. Então, ela como já tinha sido formada pela USP, fez Pedagogia, os seus quatro anos de Pedagogia, ela viu que o material que nós tínhamos lá era tão básico, do básico, do básico, sabe? Não se aprofundava em nada, não dava tempo pra você formular na sua cabeça, pra você interiorizar um aprendizado.

A depoente conclui:

Esta profissão de professora a gente já tem uma idéia porque nós somos alunos. E eu acho que a gente acaba sendo o mesmo professor que você teve como imagem lá. Não tem muita mudança.

Ser professor, como aparece de forma explícita no depoimento de Sandra, e de maneira implícita no depoimento dos outros entrevistados, fundamenta-se muito mais 
nas experiências de vida, nos modelos tidos durante a passagem pela escola, do que naquilo que os cursos de formação oferecem, uma vez que eles oferecem muito pouco, se comparado ao que os educadores já conheciam. Há um vazio entre a época em que foram alunos e a sua formação.

A desarticulação e as imprecisões conceituais observadas quando os depoentes tentam descrever as teorias e os autores estudados em disciplinas de psicologia não aparece quando falam sobre as dificuldades encontradas nos cursos de formação, ou sobre a precariedade dos estágios, ou ainda quando destacam o que lhes falta para ser um bom professor e aliviar a angústia permanente sentida no dia-a-dia escolar.

A angústia mais atual, que lhes causa tanto desespero, tem sido a inclusão, sobre a qual mostram seu total despreparo, acreditando que, se tivessem uma formação específica, poderiam solucionar muitos problemas encontrados em sala de aula:

Eu, por exemplo, não tenho formação nenhuma de inclusão. Não fiz nenhum curso de capacitação, onde que alguns professores foram preparados. Mas a grande maioria não faz parte hoje ainda do currículo obrigatório do professor, as formas e tipos de inclusão. Então o professor não está preparado. Então ele precisa de um apoio técnico, específico para esses casos [Antônio Carlos].

Antônio Carlos, ao falar sobre o seu despreparo para trabalhar com alunos que possuem qualquer tipo de deficiência, denuncia:

Porque se eu tenho um caso de inclusão por deficiência visual, eu não me sinto habilitado, eu não tenho a metodologia, não conheço braile, por exemplo. A escola não tem esse tipo de material inclusive, e os que vêm, não têm o braile. E que inclusão é essa? A questão da surdez: a gente não tem nem material didático, e nem humano também - de novo eu me coloco como humano - quando eu falo eu estou me colocando, eu, Antônio Carlos, não tenho informação para tratar com deficiente auditivo também. Então é essa a questão da formação. Quando eu falo da carência, é da metodologia e 
um pouco da formação específica de cada caso de inclusão. Porque cada caso de inclusão é um caso diferente. E é uma formação ampla. Diversificada, a inclusão. Uma infinidade de formas e tipos de inclusão. $\mathbf{E}$ eu acho que a formação tem que ser séria. Ela não é de curto prazo, ou de médio prazo. E não sei, não é dessa forma que está sendo encaminhado. Quando você tem o trato com algumas pessoas deficientes físicas, alguma coisa é possivel fazer. Que é aquele que está mais próximo do nosso do trabalho. Mas em outros casos de inclusão estão distantes. Nem material didático existe preparado para atender. O código lá, de quem é auditivo. Não só o braile, mas o código de sinais. Libras. Esse processo tem que ser trabalhado na escola inteira. É o que eu falo: o aluno se comunica não é só com o professor. Ele está lá na porta, ele sofre um acidente e quer se comunicar, a escola toda tem que ter essa formação. Ou vai ter que chamar um professor para saber o que aquela criança está querendo dizer? [...] Ou ele quer pedir alguma coisa lá para a merendeira na cozinha. Quer dizer, essa formação ela não é explícita. Ela não é explícita. A escola inteira tem que estar preparada para isso, entendeu?

Wanda também destaca as mesmas dificuldades de Antônio Carlos:

Eu não fui formada pra ter alunos com deficiência mental, que agora tem a inclusão, você sabe disso. Eu não fui formada pra isso. Fui formada pra lidar com crianças normais.

A professora aponta, além da falta de formação específica para lidar com portadores de necessidades especiais, a dificuldade para trabalhar com adultos, uma vez que sua formação foi toda voltada para a educação de crianças. Wanda leciona há sete anos no curso de Educação de Jovens e Adultos:

Aquela formação eu fiz pra crianças pequenas. Hoje em dia, eu estou com os adultos. Então, pra mim mudou bastante. Eu fiquei dezesseis anos com primeira-série. Eu era aquela professora que a filha da servente ficava comigo, a sobrinha da professora. Agora, como a necessidade do dinheiro é maior, passei pro noturno, pra ganhar mais. Passei pro noturno e gostei. Mas, eu não fui preparada, nunca fui preparada pra trabalhar com adultos. Às vezes, eu vou ensinar os dois " $r$ ", o " $r$ ” fraco e o " $r$ " 
inicial, eu conto a mesma história que eu contava pras crianças [...] Então um curso pra adultos, eu acho que seria muito bom também professor pra adultos, porque tem muito adulto que precisa ser alfabetizado e terminar de estudar e professor também não foi preparado pra dar aula pra adultos, só pra criança normal.

Novamente percebe-se o esboço de uma crítica à formação, mas ao mesmo tempo não se discute o que significa trabalhar com crianças normais e, muito provavelmente, a maioria delas que não atende à expectativa da normalidade, mesmo que não possua um diagnóstico médico, é classificada como anormal. De qualquer forma, os professores têm clareza de que a escola não vai bem, apesar de ainda não compreenderem seus verdadeiros motivos.

É preciso ressaltar, todavia, que vários são os momentos em que críticas à realidade escolar estão presentes nas entrevistas, principalmente quando se referem ao descaso dos órgãos governamentais quanto à inclusão. Antônio Carlos fala longamente sobre o assunto:

Acho que essa formação, não passa só pela formação do profissional, do professor. Passa pela formação da escola como um todo. E quando eu falo formação da escola, não é só formação não, ela passa pelo prédio, tudo [...] Essa formação não acontece nem a nível nem de coordenação, nem de direção. Nenhum profissional da escola foi preparado para isso. Os operacionais, quer dizer, pior ainda. Quer dizer, pouca formação acontece nesse nível. E eles são educadores, são agentes escolares, estão na escola, trabalham diretamente com as crianças. E chega um caso de inclusão, eles têm que estar preparados também para esses alunos. Eles se deparam com o aluno no prédio, no corredor. Como que está a cabeça dessa inclusão? Quer dizer, é um trabalho que tem que acontecer de formação na escola inteira.

Eu não gosto dessa palavra também, formação, porque parece formação, que a pessoa foi a um curso. Mas a formação como apropriação, dar informações para pensar essas questões. Nesse sentido. As pessoas precisam se informar mais, estarem preparadas, informadas, para poder encarar as novas dificuldades da inclusão. A questão da informação é muito importante. A informação junto com a formação. Acesso. Você precisa ter acesso à informação. Nem esse mínimo do básico é proposto para o professor nessa divisão [de ensino]. Uma bibliografia, uma fonte onde ele 
pudesse buscar, acessar mais informações sobre esse conteúdo. Eu não tenho isso. Está muito solto.

Acho que tem que se garantir a manutenção da formação do professor. E eu disse da outra vez, que não é dando cursos gratuitos. Os professores não querem isso. Mas possibilitando horários. Porque o professor trabalha período integral às vezes na escola. Então é preciso ainda que a administração se sensibilize, se o professor quer se formar, tem que dar condições de tempo, ou de espaço, para ele se formar. Porque tem outros professores que falam: “Não a prefeitura não dá cursos”. Eu não estou questionando isso. Acho que os professores devem ir buscar cursos. Mas ele tem que ter condições de ir buscar, tem que ter tempo. Ou tem que ter uma dispensa, ou tem que ter um período do ano que ele possa ser liberado para essa formação, entendeu? Então eu sinto assim, percebo essa falta de tempo para a formação do professor. E a outra questão é a inclusão. Quer dizer, a inclusão entrou dentro desse processo e o professor não acompanhou esse processo. Chegou para ele sem todo um processo de formação, de construção de conhecimento junto com o professor para ele se preparar para inclusão. E que eu falei, tanto o professor, não só a pessoa humana, questão humana, mas a questão física, técnica. Os prédios, os operacionais.

O professor relata e denuncia como tem ocorrido o tão divulgado processo de inclusão nas escolas. Nas entrevistas, ele tem a oportunidade de dar sua opinião, falar sobre como a formação deveria acontecer, quais os conteúdos de que sente falta no seu dia-a-dia. Por isso, talvez, seja tão freqüente a dificuldade dos depoentes em se lembrarem de conteúdos aprendidos em cursos em que não tiveram qualquer poder decisório em sua elaboração. Realizam os cursos de forma obrigatória, como aponta Sandra:

O curso superior vem da $L D B^{41}$, é uma exigência da lei federal. E aí como eles estão exigindo que todo professor tenha o curso superior, a prefeitura, o governo do estado, primeiro, ofereceu o curso gratuito aos professores do estado. Dois anos depois, a prefeitura ofereceu o mesmo curso gratuito aos professores da prefeitura e aí vem aquela coisa: eu não tinha vontade nenhuma de voltar a estudar, muito menos à noite, casada, com filho. Aí as professoras: "Não, vamos, faz a inscrição”. Aí fizemos a

\footnotetext{
${ }^{41}$ Lei de Diretrizes e Bases da Educação Nacional.
} 
inscrição juntas, escolhemos o local de estudo juntas e aí foi meio "Maria vai com as outras” mesmo. Talvez se só eu, naquela escola que eu estava há três anos atrás, tinham muitos professores que não tinham curso superior. Aqui já não acontece isso, entendeu? Lá no NAE $5^{42}$, naquela região do Campo Limpo ${ }^{43}$, são muitos professores que não têm o curso superior. Até eu fiquei espantada. Porque quando você vai preencher uma ficha e coloca a sua formação, eu imaginava que quase todos os professores tivessem Pedagogia, que eu não tinha, porque na época não pude pagar, nem pensei em fazer USP, muito menos isto, mas não. Muitos mesmo só tinham curso de magistério. Aí lá nós fomos nove professores pra fazer o curso. Isso foi muito bom, porque um ajuda o outro, um anima o outro. E foi mais nesse sentido. O curso foi próximo de casa, não foi difícil, de fácil acesso, era pela USP os professores. Apesar de toda essa tecnologia nova aí, de vídeo-conferência, teleconferência, que era uma novidade pra mim, não tinha nem idéia do que era isso. Então, foi mais nesse sentido mesmo. Um foi falando pro outro, nós fomos escolhendo o lugar pra fazer o curso e conforme foi montando os grupos, como montou um grupo muito grande em Taboão da Serra, então o curso foi em Taboão da Serra. Isso ficou muito perto e então não dava pra falar: "Não vou fazer o PEC”. Porque nós também não sabíamos se mais tarde a lei ia realmente tirar os professores que não têm o curso superior.

A motivação para o curso vem do medo de perder o cargo. Perdem-se o significado de ser professor e a função dos cursos formativos.

Ao analisar os cursos oferecidos pelas Secretarias de Educação, Maristela fala sobre suas frustrações e denuncia:

Uma das coisas que mais me chamaram a atenção quando eu estudei pra ser professora, é a visão que eu tinha de mim mesma é que eu seria uma erudita. E que essa é a qualidade do professor. Que ele é sobretudo um erudito. E, portanto, alguém com cultura suficiente pra ter tolerância com o outro, pra ter entendimento do outro. Pra amenizar conflitos, pra criar bons conflitos [risos]. E que quando eu cheguei na escola não foi bem isso que eu encontrei. Professores que não gostam de ler, professores que minimamente preparam suas aulas, professores que não entendem, que não dão valor à

\footnotetext{
${ }^{42}$ Núcleo de Ação Educativa (número 5), órgão pertencente à Secretaria de Educação da cidade de São Paulo.

${ }^{43}$ Bairro da cidade de São Paulo.
} 
magia da questão da expressão escrita, da expressão da oralidade. Não gostam de cinema, não gostam de teatro, enfim, expressam-se muito mal. Mas pra mim foi um pouco chocante. Eu encontrei pessoas eruditas, mas a maioria de senso absolutamente comum. Conseqüentemente, você não muda muito a realidade. Assim, se você é comum, igual, como é que você pode fazer algum tipo de diferença? Como é que você pode causar algum tipo de destaque na realidade? Nenhum. Eu participei de sindicatos durante muitos anos. Está na pauta de reivindicações uma formação continuada de professor. Ao que as Secretarias nos respondem, nos oferecendo cursos medíocres, em horários incompatíveis com os nossos horários de trabalho que não têm qualquer aplicabilidade em sala de aula. Aí toda uma perfumaria que, sinceramente, não faz a menor falta na maioria das vezes. Por outro lado, eu já fiz cursos interessantíssimos. Mas na maioria das vezes não. Não se dá a menor atenção por parte dos órgãos governamentais. $O$ professor também não exige algum tipo de fato que marque o início de uma formação continuada. As exigências são pequenas. Que não incomodam ninguém. Geralmente a exigência vem em torno da questão salarial, que também é importante. Quer dizer, não é possível se comprar um bem material, um bem cultural, especificamente, quando você minimamente não consegue dar conta de necessidades básicas. Então eu acho injusta essa colocação [de que os problemas da escola se devem ao despreparo do professor]. Acho bastante clara e importante. Admito que há um despreparo do professor, mas tenho refletido na qualidade da educação, sem dúvida nenhuma. Mas uma palavrinha que não quer tirar da minha boca é co-responsabilidade. Órgãos governamentais, o professor. E muitas vezes na escola um tipo de formação que eles dão nome de momento de formação continuada, quando você senta lá naquela mesa de reuniões da sala de JEI e lê apostilas. Quer dizer, isso eu faço na minha casa.

A depoente fala da necessidade de encontrar um sentido em sua atividade profissional para fazer diferença na vida de seus alunos. A formação, que poderia contribuir para isso, apresenta-se como incompatível com as necessidades e possibilidades do professor. 
Outro aspecto relevante da formação é o contato que os depoentes tiveram com a Psicopedagogia. Especificamente, as professoras Márcia e Nancy fizeram esse curso, que permeia sua atuação como professoras e suas explicações para os fenômenos que ocorrem em sala de aula. Márcia fala sobre os conteúdos vistos durante a formação:

Distúrbios de aprendizagem, psicoses, dislalia, disgrafia, alexia, afasia, dislexia, que eu também acho super complicado.

Além disso, descreve com detalhes sua monografia de conclusão de curso:

Então, a monografia foi no terceiro ano. Eu acabei fazendo um relato da prática que eu tive nesses dois estágios que eu te falei, do Jaguaré, do hospital do câncer, e eu também fazia oficinas de cerâmica nas férias, em julho e dezembro. Mas eram com crianças de escola particular, material caro. Mas o tema era arte no caminho da transformação. Então, como que a arte pode ajudar as crianças, ajudar os adolescentes a ter mais recursos mesmo para lidar com os desafios. $E$ como que ela pode levantar a sua autoestima. Porque não tem muita coisa de desenhar certo, desenhar errado, pintar certo, pintar errado. Então, meio que assim, todo mundo acertava e todo mundo socializava as condições, se sentia valorizado. Então eu acho que tem este lado legal. E é uma coisa já que acaba sendo mediadora. Acho que arte acaba sendo mediadora, ela facilita o trabalho. Eu gosto de dar bastante coisa de arte para eles. Porque até eu estava explicando para eles. Recortar, que eu vou ver quem está com facilidade, quem tem dificuldade para recortar, e quem tem dificuldade para escrever. Os alunos têm letra tremida, letra feia, então eu fiquei treinando os recortes com eles. E eu acho que é um mediador que te ajuda nas outras coisas na própria alfabetização. Eu fiz bastante fotos na monografia, ficou legal. Fiquei um pouco chateada, porque eu não tive retorno nenhum. A gente tendo a monografia, eu apresentei, e aí eu tive uma revisora crítica. Eu tive uma orientadora, e tive que escolher alguém para ler a monografia, e dar um retorno. Eu escolhi duas pessoas que eram arte-terapeutas. Eu fiz sozinha, essa do Jung, eu e uma outra que era arte-terapeuta, que trabalhava só com coisas de arte, ela tinha um ateliê, e eu nunca tive retorno. Elas nunca escreveram nada, e eu até cheguei a cobrar, porque eu deixei cópia lá, deixei uma cópia na biblioteca, deixei uma cópia para a orientadora, outra para a professora. E nunca tive retorno nenhum. Mas para 
mim valeu. Eu acho que ficou, apesar de eu ter ficado decepcionada, acho que valeu, está bem registrado, está bem teorizado.

A arte aparece como um conteúdo estudado durante o curso de Psicopedagogia e que poderia auxiliar nos problemas de aprendizagem dos alunos. Márcia fez a monografia a partir de seus estágios com crianças analfabetas e outras com câncer. Utilizou, como relata acima, Jung para fundamentar a monografia. Ao final, não obteve o retorno que desejava dos docentes que avaliaram o trabalho.

Com Nancy, algo semelhante ocorre. A depoente considera que não se sentiu habilitada para a Psicopedagogia quando terminou o curso e comenta a postura dos educadores:

Eu não achei que eu estava capacitada para Psicopedagogia quando eu terminei. E eu ficava doida de ver as pessoas que saíam e abriam consultório. Eu falei: "Não tenho coragem. Será que eu sou medrosa?” - pensei comigo. Mas eu achei que ninguém lá estava capacitado. Mas, de repente, as pessoas se achavam. Não sei. E então, nossa, “eu já estou vendo consultório e tudo!”. E a Psicopedagogia, eu acho que ela bota muita psicologia, e quem fez Pedagogia, não tinha um monte de coisa lá que foi dado. Então, às vezes, eu entrava num pânico comigo mesma, porque eu falava: "Ai meu Deus, eu não sei isso daí, eu não tive em psicologia, eu tive uma coisa elementar, uma basinha, uma base pequenininha". Eu falava: "Nossa, isso daí, eu acho que eu tinha que fazer uma faculdade de Psicologia para entender melhor isso daí", eu nem lembro mais o que era, mas eu sei que eu tinha às vezes um conflito, eu ficava meio estressada, às vezes, sabe? De pensar: "Meu Deus! Isso daí é que eu tinha que aprofundar mais", uns testes lá, que tem textos de psicologia. Ela [a professora do curso de Psicopedagogia] falava algumas palavras muito de psicologia, que quem fez, sabia. Eu até virei um dia para a professora e falei assim: "Olha, o curso, eu acho que é mais voltado para quem fez Psicologia. Porque tem mais base". "Não, isso daí é para professores também", aí eu fiquei quieta. Mas mesmo quando teve aula prática, que a Heloísa Quadros levou a gente para uma escola aí que ela dava aula e era diretora que eu lembro, ela parece que não queria mostrar para a gente a parte prática, os jogos que ela usava, estavam meio escondidos, parece que ela não queria difundir muito este lado prático, e eu percebi isso daí, eu falei: "Nossa, parece uma máfia isso 
daqui, não vamos divulgar. Vamos dar a parte teórica e ele se vira". Eu senti isso na época. Aí eu saí de lá e falei assim: "Bom, o que ficou, ficou, o que eu vou ler, o que eu vou me complementar, não sei depois de ler o que eu vou fazer". Mas eu não tinha essa confiança de ter uma boa base, não [...] Mas, eu acho que, para sala de aula, o que eu tenho, com o estudo, eu acho que dá para desenvolver bem. Eu acho que não estou entrando em conflito, sabe? Eu acho que está bom. Para abrir uma clínica para fazer um negócio mais sério, eu acho que precisa um bom caminho aí.

Neste caso, o curso, apesar de ter sido avaliado negativamente por não ter oferecido todos os subsídios necessários para a professora atender clinicamente em um consultório, dá os elementos para lidar com os alunos em sala de aula. A falta de segurança para diagnosticar e intervir clinicamente também aparece no relato de Márcia:

Mas, mesmo tendo estudado eu acho super complicado. Acho que uma coisa que você tem que se aprofundar muito para saber, e para não confundir. Porque, a gente confunde muito. Eu tenho uma aluna este ano, que a avó, no primeiro dia de aula, falou que ela era hiperativa pra mim. Ela estava preocupada. Ela é hiperativa, ela falou: "Olha, ela perdeu a mãe, ela mora comigo, faz três anos que a mãe faleceu, e ela não pára, ela é hiperativa...”. E eu percebi que ela é uma menina muito agitada, ela tem dificuldade de sentar, as coisas dela vivem caindo no chão, uma série de coisas, mas, eu não classificaria como hiperatividade. Porque ela fica sentada, ela faz as lições, ela tem dificuldade de concentração, tudo, mas ela faz. E eu acho que as pessoas acabam generalizando muito, sabe? "Todo mundo que é agitado é hiperativo, todo mundo...", não é assim, né? Então eu acho que tem que tomar um certo cuidado, e eu tenho muito medo de diagnosticar e confundir. Falar é isso, e isso não é. Eu acho uma classificação bem complicada. Acho que tem que estudar muito, precisa ter muitos exemplos. Eu tive aquele panorama geralzão, mas eu não saberia, eu acho, identificar. Só se fosse um caso muito típico.

A professora percebe a generalização que é feita em torno das crianças: tornou-se “moda” dizer que os agitados são hiperativos. Mas, ao mesmo tempo em que possui certa clareza dos males da classificação, retoma a importância do diagnóstico. 
As conseqüências são explícitas: mesmos para aqueles que não possuem a formação específica em Psicopedagogia, sua presença está implícita e fortalecida no contexto escolar, colaborando para a realização de diagnósticos feitos pelo professor e exigidos pela Secretaria de Educação. A Psicopedagogia é mais um instrumento utilizado pelo docente para realizar a classificação daqueles alunos que não aprendem os conteúdos escolares ou não se comportam de acordo com as regras estabelecidas pela instituição:

Porque eu lembro que teve um ano que uma professora fez um relatório que as coordenadoras tanto pedem pra gente fazer dos alunos que têm dificuldades especiais. E aí a professora escreveu, acho que tinha mais de dez alunos ali. Ela escreveu: "Fulano, hiperativo, fulano, hiperativo". Então eu acho complicado, porque quando tem algum laudo médico é mais fácil, mas quando não tem, a gente fica naquele "achômetro": "Ai, eu acho que o menino...". Aí, eu acho assim, que tendo estudado, tendo esta base, eu até tenho uma certa noção de distanciar, sabe? "Desconfio que o fulano tem algum problema neurológico, ou algum rebaixamento mental...”, sei lá... que já aconteceu, os alunos que não tinham o laudo médico. Aí a gente encaminha. Na maioria das vezes as mães não querem levar. É difícil aceitar que ele tem algum problema, trabalhar isso. Mas, eu acho bom ter essa noção. É tudo muito específico para você entender. Eu acho que eu tenho uma visão geralzona [Márcia].

Como aponta Márcia, o professor age no “achômetro”, mas seus diagnósticos são tidos como legítimos para encaminhar os alunos para tratamentos clínicos ou simplesmente atualizar o cadastro dos órgãos governamentais.

Já que, como ressalta a professora, há, em alguns casos, cerca de dez alunos em cada classe classificados como hiperativos, as demandas do professor para a psicologia só poderiam estar relacionadas a como resolver, de forma imediata e "prática” os problemas desses alunos. Assim, o que os depoentes gostariam de aprender sobre psicologia não passa por Freud, Vigotski, Piaget, Wallon ou Emília Ferreiro. Querem soluções: 
E eu acho que nessa formação de professores, a psicologia devia estar presente na formação, pensando na inclusão, nesses portadores de necessidades especiais aí, acho que a psicologia seria uma grande força pra ajudar na formação [Antônio Carlos].

Eu acho que mais como a gente conseguiria perceber uma certa deficiência, dificuldade no aluno, entendeu? Problemas comportamentais que os alunos apresentam [Sandra].

Bom, fora metodologia, que você tem metodologia mesmo, mas uma metodologia adequada ao nível de aluno. Na hora de formar um planejamento, ter a assistência de uma psicóloga também, sabe? Porque muitas vezes você está planejando ali uma coisa que não tem muito sentido, que não precisava ser dado naquela hora, que pode ser dado depois. No planejamento acho que faz falta também. No planejamento, metodologia, lógico, sempre vai precisar, que mais? Postura mesmo do professor [...] A formação da gente como ser humano, como agir [Wanda].

Carla apresenta com clareza a distância entre os autores estudados nos cursos de formação e a realidade “concreta” da escola:

Olha, eu acho que não deveria dispensar a leitura dos autores. Eu acho que somado a isso, deveria ser feito alguma coisa mais concreta. Eu acho que a faculdade deveria ter um grupo de estudo que ajudasse algumas crianças e que a gente pudesse estar observando essa ajuda, sabe? Estar ali vendo que Freud explica, porque ele explica e ele está lá, não só porque está escrito no texto. Eu acho que faltou um vínculo com a realidade. Eu acho que deveria ser assim: eu acho que deveria ter uma sala, ter um horário específico, mesmo que fosse fora do horário da faculdade, mesmo que fosse de manhã, por exemplo, de tarde, não seria o problema, que fizesse parte da grade, que você fosse apontado por isso, por estar lá ou não. E que você estivesse fazendo interferência com a criança. Você estudar, por exemplo, as fases da aprendizagem de Piaget, de você pegar uma criança com quatro anos e você sentar com ela e ver se aquilo lá que ele escreveu é verdade. Essas coisas assim. Eu acho que você lê tudo o que você lê e você não ter oportunidade de ver se isso é verdade, ter um confronto com a realidade, eu acho que pesa. 
E, finalmente, Nancy fala sobre suas necessidades, que se põem quase como a falta de um manual para lidar com os alunos:

Ah, eu acho que como lidar com o aluno, como lidar com as dificuldades, uma coisa bem prática. Um aluno agressivo: que atitudes que você tem que tomar, que atitudes não se deve tomar, como conversar, como ensinar? $O$ aluno tímido... $O$ aluno... sei lá, o que pode ser? $O$ aluno distraído, como detectar uma hiperatividade numa criança? Que, às vezes, a gente acha hiperativa, e não é nada disso. Então a gente, às vezes, erra inocentemente, porque a gente não sabe. Então, dentro da psicologia, se tivesse assim, bem prático. $O$ aluno tal, o que faz? $O$ aluno assim, o que faz? $O$ aluno assim, o que faz? Como, numa situação emergencial da classe ficar tumultuada por conta de acontecer tal coisa: como a gente reagir? Uma coisa bem prática. Isso talvez ajudaria, dentro desses cursos aí.

A prática. A importância do diagnóstico. Mas, junto com ele, a necessidade de se saber o que fazer.

Percebe-se, a partir do relato dos depoentes sobre a formação em geral e a formação em psicologia, a realidade precária dos cursos de magistério, de Pedagogia, de Psicopedagogia e da formação continuada, seja por meio do PEC ou em JEIs. Apesar de passarem muito tempo estudando autores e teorias que, na verdade, apenas se repetem, não há qualquer aprofundamento sobre eles. Ao final de vários semestres de formação em psicologia, os professores conseguem citar nomes de autores, confundem fatos e fornecem dados imprecisos.

Não se lembram dos conteúdos estudados não só de psicologia. Criticam toda a formação, a partir de dois aspectos: a) os pedagógicos, que se referem à estrutura e ao conteúdo dos cursos, à didática dos formadores e às exigências descabidas e b) a aplicabilidade, que diz respeito à distância do conteúdo aprendido - considerado teórico e abstrato - com a prática. 
Embora passem anos de sua vida profissional preparando-se para ser professores e continuem estudando até mesmo nas escolas durante os momentos de formação continuada, ao final parecem estar bem próximos do que afirma Sandra:

Esta profissão de professora a gente já tem uma idéia porque nós somos alunos. E eu acho que a gente acaba sendo o mesmo professor que você teve como imagem lá. Não tem muita mudança.

Por isso, talvez, desejem a psicologia, não nos cursos de formação, mas dentro do espaço escolar, próxima do que denominam "prática”. 


\section{CAPÍTULO VI - A RELAÇÃO TEORIA-PRÁTICA: busca de eficiência pedagógica}

Porque eu acho que teoria só por teoria não leva a nada [Nancy].

A relação entre teoria e prática permeia a fala de todos os depoentes nos diversos aspectos que compuseram as entrevistas. Assim, tratam da teoria e da prática quando falam de sua formação em psicologia ou da formação em geral, quando apresentam suas demandas para os psicólogos nas escolas ou quando dizem sobre suas dificuldades do dia-a-dia.

Um primeiro aspecto importante sobre este tema é a relação que estabelecem entre teoria e leitura: ler significa permanecer apenas no âmbito teórico. Os professores questionam a validade das leituras que são realizadas nas reuniões pedagógicas nas escolas, muitas vezes orientadas por psicólogos ou por coordenadores pedagógicos, já que elas não tratam dos problemas cotidianos. As leituras se contrapõem aos estudos de caso. Estes são tidos como mais válidos, pois se aproximam dos problemas dos alunos, são a prática:

Eu comecei a questionar [durante uma reunião pedagógica] por que a gente estava lendo texto, por que a gente não estava fazendo estudo de caso e aí falaram como seria interessante ter um psicólogo. Teve gente que falou que se fosse pra ler texto e pra encher o saco, que era melhor que não viesse, que não tivesse ninguém, que era bom que não tivesse ninguém. Agora, que se fosse pra fazer estudos de caso, que talvez fosse interessante, porque você ia falar do problema que você tem na sala e alguém ia te dar uma luz, sabe? [Carla].

Sandra declara que prefere os programas de TV à leitura:

Mas, é aquilo que eu já te falei, sou muito preguiçosa, não me manda ler porque eu não vou ler. Se quiser passar na televisão eu assisto de bom grado. Se quiser uma 
palestra, eu assisto de coração aberto. Anoto, faço mil anotações, ah, mas não me manda ler. Então, o que acontece? Acaba ficando no esporádico. Se aquilo aparecer, se uma coisa da psicologia aparecer, num programa que eu estou assistindo, ou numa palestra que eu estou ouvindo, eu vou aproveitar. Mas se também não aparecer, eu não vou atrás procurar.

Em outro momento, a depoente contrapõe as palestras e os cursos de formação a grupos de estudos que poderiam discutir problemas de seus alunos:

Porque se for palestra, ou se for grupo de estudo, serão discutidos assuntos que surgirem naquele estudo. Palestra piorou, porque palestra, o palestrante normalmente ele coloca lá o objetivo da sua palestra e depois abre pra discussão, que são pouquíssimas que dá pra discutir. $\boldsymbol{E}$ mesmo assim fica só no teórico. $\mathrm{O}$ bom mesmo seria o dia-a-dia. Ou ter semanalmente um grupo de estudo. Agora, se fosse grupo de estudo, com uma certa freqüência, pra resolver problemas do aluno - não do professor, não de relacionamento, mas do aluno - ainda surtiria algum efeito. Teria alguma coisa de concreto acontecendo. Agora, palestras não resolve, aqueles cursos também que você vai só para absorver não resolve, é o contato mesmo.

Carla, afirma que a teoria - por ela identificada com leitura - contribui para a formação do professor, mas não para enfrentar os “casos” do dia-a-dia. Ela fala da incompatibilidade entre teoria e prática:

E eu acho que teria que ser uma coisa sem ficar lendo texto, texto, texto, sabe? Eu acho que tinha que ser estudo de caso. Eu acho que o psicólogo deveria entrar na sala um dia ou outro [...] Eu já tive experiência com psicólogo na escola, mas ficava lendo texto, texto, texto, texto e aquilo não ajudava, entendeu? Ajudava na minha formação, mas na sala em si não me ajudava, porque eu não estava estudando um caso diretamente. Então, na minha formação me ajudou, mas não ajudou no que era necessário. Porque quando a gente está na escola, o importante é a criança, não é a gente. A minha formação eu tenho que fazer fora daqui. Eu tenho que buscar um curso, eu tenho que buscar uma faculdade, eu tenho que buscar uma capacitação, alguma coisa assim [...] Eu acho que o problema é assim, o estudo que eu tive ele foi 
bom, porque se você partir do pressuposto que você tem que ter uma base, realmente eles me deram uma base boa que não tem ligação com a realidade dos problemas educacionais, mas não perde o seu mérito. Mas quando você chega na sala, e percebe que tem um caso que não estudou na escola, não estudou na faculdade, não pode chegar lá e dizer: "Ó, escuta, o que eu faço?”.

Maristela conta sobre o livro de Psicologia Educacional que teve contato durante a disciplina de mesmo nome, presente em seu curso de História:

É um livro até que interessante, mas muito conceitual. Nenhuma situação problema, nenhum estudo de caso, nada não, tudo muito conceitualzão [...] Pra mim interessante seria se tivesse aplicabilidade, por isso que eu falo da questão de uma literatura mais voltada pros casos, pras situações-problema. Lá tinham definições de teorias psicológicas ligadas à educação. Não me atraiu, você entende? Não me atraiu.

Antônio Carlos destaca a necessidade dos estudos acadêmicos se aproximarem da escola, pois aqueles não chegam até o contexto educacional:

E eu penso assim, bem cegamente, sem experiência, mas que a psicopedagogia ou a psicologia tem muito a contribuir, deve ter muita experiência pra passar nessa área da educação, que a gente precisa de alguma forma trocar isso, trocar essas informações. Que não seja uma coisa acadêmica. Que todas essas experiências, esses resultados, não fiquem só dentro do acadêmico, que venham pra escola, que isso volte pra escola, que contribua. Porque muitas vezes algumas experiências, elas se dão só a nível acadêmico e não saem de lá e não saem do papel. Acho que tem que transformar isso, voltar a fazer parcerias com as Universidades, e que isso chegasse até as escolas. Que essas pessoas que estão nessa área viessem, trouxessem essas experiências acadêmicas pras escolas, que viessem fazer estágio nas escolas. Acho que se isso fosse mais difundido, acho que ia ser uma troca rica. A escola ia contribuir com a realidade, e a realidade com a teoria.

Esta separação entre as teorias aprendidas nos cursos de formação e a realidade de sala de aula está presente em outros depoimentos. Para Nancy, as aulas das quais 
participava na graduação sempre foram “muito teóricas” porque não davam exemplos práticos, não ensinavam como transportar a teoria estudada para a vida cotidiana:

Piaget, eu ouvi pela primeira vez Piaget, também eu achei super-interessante. Não entendi nada no começo - o que era acomodação, assimilação, essa coisa toda - e eu tive que buscar sozinha, porque eu não conseguia entender direito na aula, porque era muito teórica também, e eu fui tentando, quando eu lia, transportar pra vida prática, pegar exemplos práticos da minha vivência, pra ver o que era assimilação, o que era acomodação, o que era transferência numa criança, quando eu dava aula.

Sandra, ao falar sobre a psicologia em sua formação, também aponta a dificuldade em relacionar seus conteúdos com a vivência em sala de aula:

Então, para mim, quando falam em psicologia, eu não sei ligar a psicologia ao conteúdo do dia-a-dia. Eu só sei ligar psicologia ao comportamento. Ao trato com as pessoas. A forma como você interage com os alunos. Só sei ligar a psicologia a isso. Ao conteúdo, a mudanças na forma de ensinar um certo conteúdo qualquer aí, eu não consigo fazer essa ligação da psicologia na prática de sala de aula.

A teoria aprendida é abstração, que ela diz não conseguir relacionar à prática de sala de aula:

É muito bonita a teoria no PEC, em qualquer curso. Mas quando chega na sala de aula que você fica desesperada, sem saber o que fazer... [Sandra].

A depoente fala, ainda, sobre o interesse em aprender o que é prático, ao invés do que considera teórico:

Enquanto eu estava estudando no PEC, por exemplo, na parte teórica eu detesto! Passou batido todos os pensadores, eu fui vendo um, outro. Mas quando chegou na parte prática, cada matéria, Português, Matemática, eu babava, sabe? Eu babava! Ficava encantada de ver como pode ser trabalhado Português, como pode ser trabalhado Matemática, “Olha que legal, nunca pensei nisso! Ninguém nunca me falou 
disso! Não sei o quê". Só que chega na sala de aula, a situação é outra, completamente outra. Então, às vezes, de várias atividades de Matemática, eu conseguia montar uma e ficava toda contente porque eu consegui montar aquela. Mas, não é do meu dia-a-dia.

No entanto, mesmo as atividades práticas ensinadas mostram-se difíceis de serem desenvolvidas no cotidiano. Isto ocorre, geralmente, porque o que é aprendido aplica-se a uma outra realidade escolar, como aponta Nancy:

Porque, por exemplo, quando a gente vê vídeos, quando a gente lê nos livros, os estudos são sempre assim: pequenos grupos de crianças de seis ou sete que se aplica. Mesmo quando a gente via vídeos do construtivismo, a criança sendo alfabetizada, era para grupos pequenos, a professora tendo tempo de ver as hipóteses da criança, os desafios. Psicopedagogia também é para pequenos grupos, se não for individualmente também. Você tem de se dedicar àquela criança. É difícil aplicar algum conhecimento quando você tem uma classe de quarenta às vezes. Você quer ficar mais perto da criança, você quer atender mais. Às vezes, você vai para casa: "Ai, meu Deus, aquela criança, eu podia ter atendido mais".

Da mesma forma, Sandra se refere à distância entre a realidade das teorias estudadas e a realidade escolar em que trabalha:

Eu acho legal estudar teorias, ver todas elas, e saber também qual era o contexto histórico da época, eu acho importantíssimo. Como eu falei, todas essas teorias normalmente acontecem com um grupo pequenininho, mesmo os que são em sala de aula eram uns grupos pequenos, era na Europa, uma outra realidade, totalmente diferente da nossa, em relação à condição social das pessoas. Então eu acho legal saber em que contexto foi estudado, para saber se tem condições de passar para nossa realidade.

Os depoentes consideram a teoria positiva ou negativa somente se atinge o critério de aplicabilidade ou de utilidade. E prático, para eles, é sinônimo de útil: 
Porque quando eu fiz graduação [em Pedagogia], eu acho que eu era muito nova. No começo eu não trabalhava, então para mim era tudo meio distante mesmo. E na Psicopedagogia eu já estava bem mais experiente profissionalmente, fui eu que fui buscar. Então eu fiquei um tempão batalhando pra conseguir fazer o curso. E por isso escolhi um curso mais prático, e também os estágios, acho que ajudaram. Porque os estágios que eu fiz na graduação são aqueles estágios de observação, de você ficar só observando as aulas. E eu fiz, né? Eu cumpri todas as horas. Eu fiz lá, todas as horinhas. Mas não me ajudou sabe? [...] É que os estágios foram a coisa mais prática, mas mesmo na graduação acho que não foi legal, não gostei dos estágios, não me foram úteis. Foram só também pra cumprir, sabe? Colocar no papel e ter o diploma mesmo, porque aprender mesmo, não aprendi [Márcia].

Sandra considera que uma teoria só deve ser ensinada se tiver uma função, se tiver aplicabilidade ou utilidade:

Logaritmo, ou outras coisas difíceis de Matemática. Você vai usar o que na sua vida? Nunca. Então eu acho que isso é uma coisa que deve realmente ser repensado. Por que aprender isso? Se tiver uma função pra se ensinar isso - por exemplo, Matemática não precisa dizer uma coisa difícil - vamos pensar em equação de terceiro grau, de segundo grau, que pros alunos é difícil. Qual é a função disso? "Ah, vai desenvolver o cérebro, o raciocínio, vai ser bom pra isso...”. Então deve estar no currículo. Agora, se não tem utilidade, por que aquilo? Por que há quinhentos anos se ensina isso? Então se deve pensar. Eu acho que psicologia - por que existe psicologia? Pra você ter uma noção do todo. Da criança como um todo. Das fases de desenvolvimento psicológico, crescimento. Então você tem uma noção do todo. Mas que aqui não vai te ajudar, no dia-a-dia da escola, não é a questão de ser pessimista ou não, mas eu não vejo.

Útil é aquilo que pode ser aplicado no dia-a-dia escolar; é o que ajuda a resolver problemas imediatos. Sandra considera que a psicologia dos cursos de formação não contribui com as questões mais urgentes da escola.

Maristela, ao falar sobre sua formação em psicologia, destaca a necessidade de a teoria ser “viva”, ou seja, ser útil em sala de aula: 
Ah! Não! As teorias quadradas dos manuais acadêmicos, não! Pelo amor de Deus! Mas aquela que fosse uma combinação disso com o cotidiano mais real de sala de aula, por exemplo, de relações humanas. Eu acho que ela [a psicologia quadrada dos manuais acadêmicos] é uma parte importante dessa possibilidade toda que a psicologia traz à escola, aplicada à escola. Mas, tem essa coisa viva, do dia-a-dia, dos alunos, da história, do que acontece na sala de aula.

É comum, também, encontrar nos depoimentos a idéia de que só se aprende na prática:

Muita coisa você vai aprender na sua prática. Magistério não te dá base. Não te ensina a dar uma aula, se é importante dar ou não dar um ditado - que hoje, todo mundo ainda usa o ditado - mas qual é a importância do ditado? [Sandra].

Nada como a teoria ligada à prática. Porque sempre a gente vê muita teoria e pouca prática. No magistério, por exemplo, eu lembro quando eu fiz, que a professora mandava preparar uma aula pra primário - que chamava naquela época - e eu preparei uma aula, me lembro que eu preparei uma aula de Ciências, que era até sobre o ar. E levei toda uma parafernália lá numa classe mesmo, real, não virtual, numa classe real, acho que era uma terceira-série e todos os professores assistiram à minha aula com os alunos. E eu fiz uma aula, mas assim, achando da minha cabeça, que tinha que ser tudo prático mesmo pra eles entenderem. Fiz esquema na lousa e usei panelas, copos, tudo experimental lá pra eles olharem e tirarem a conclusão. Depois a professora achou maravilhoso aquilo lá que eu fiz. Mas, aquilo foi a minha intuição, porque a professora não usava nada disso na classe, ela só falava que a aula tem que ser o mais concreto e prático possível. Ela só falava. Mas, quando eu fui preparar a aula eu pensei: “O que é tornar essa teoria sobre o ar em prática?”. E aí tudo o que estava escrito lá no livro sobre experiências eu fiz em casa, todas as experiências, treinei bastante pra chegar na hora e fazer. Mas, no magistério e na Pedagogia nunca um professor fez uma aula prática pra gente. Eu acho que o magistério e a Pedagogia, Psicopedagogia tinha que ser tudo prático, mostrar material pra gente, a gente vivenciar nas aulas os materiais, pra gente quando chegar realmente numa sala de aula, estar mais segura daquilo e não aprender sozinho. Eu acho que o aprendizado sozinho é muito gratificante. Tudo o que eu sei, foi porque eu aprendi sozinha. 
Chegando em casa, consultando livros e tentando traduzir tudo aquilo lá pra prática. [Nancy].

A teoria é abstração e a prática é concreta. Mesmo que passem por diversos cursos de formação, os entrevistados consideram que o aprendizado, o tornar-se professor, só ocorrerá na sala de aula:

Porque é muita teoria, pouca prática, pouca experiência também, nos estágios também, então não te dá muita noção. Agora, quando você entra mesmo, você vai pastando, vai sofrendo, vai aprendendo, vai fazendo coisas erradas e depois já começa a acertar, aí já é mais pé-no-chão, com o tempo você vai pegando prática, mas só prática mesmo. No magistério é diferente do PEC, porque [neste] a gente já estava trabalhando. Mas a parte teórica, por exemplo, acaba ficando meio que, às vezes, num quartinho, bem escondidinho, lá dentro de você, porque você nem quer que aquilo lá modifique a sua prática, vamos dizer assim. Pouquíssimas coisas minhas foram modificadas durante os dois anos de curso [Sandra].

Diante de uma formação "teórica” que não prepara para o exercício da docência, resta-lhes aprender “na prática”, ou seja, no próprio processo de trabalho.

Quando os depoentes se referem à psicologia, especificamente, "prático" também é a possibilidade de ter a presença do psicólogo no cotidiano escolar, e não a presença da psicologia na formação. Wanda mostra como o contato entre psicólogo e escola é tido como "prática”:

Que o bom é a psicologia vir para a escola, não só ficar ensinando professor. Essas coisas que dão certo por aí, vir para a escola, o psicólogo vir, conversar: "Olha aconteceu em tal escola, foi assim”. Mostrar mais a prática. Mas a prática com os professores, e a prática com os alunos mesmo. Porque teoria acaba ficando esquecida, ficando por aí. Então, eu acho que a psicologia devia vir para a escola, a psicóloga 
estar na escola. E aí sim, orientando a gente, e a gente seguindo ali, numa amizade, numa união. Não só estar passando para mim o que você sabe e eu estar aplicando.

Para Sandra, o contato com o psicólogo traz soluções:

Se o psicólogo do meu aluno me chamasse, aí sim seria muito bom, porque eu iria colocar pra ele quais são as minhas dificuldades. Talvez até desenhar mais ou menos a minha sala, quais são os alunos que eu tenho. Que não é só aquele que é o paciente dele. Tem outros casos que também não foram diagnosticados, que também não sei se têm problemas ou não têm problemas. Então eu acho que o psicólogo na escola, ou em contato com a escola - se não for na escola, mas em contato - seria ainda a melhor solução.

Como pôde ser observado, em vários temas e momentos das entrevistas, os depoentes tratam da relação entre teoria e prática. Nancy sintetiza o pensamento sobre o assunto:

Que não adianta ficar lendo coisas, é bom, tudo bem, ler Emília Ferreiro, ler Piaget faz parte, é importante, mas vamos trazer isso para a realidade, porque fica dissociada uma teoria da prática. E para mim, eu não consigo entender uma teoria dissociada da prática. Para mim, a teoria vale, se você consegue aplicar.

E conclui:

Porque eu acho que teoria só por teoria não leva a nada.

$*$

Em linhas gerais, do que tratam os depoentes quando falam da relação teoriaprática?

Mostram, acima de tudo, a pragmatização do pensamento. Demonstram um antiintelectualismo e o desejo de aprender para aplicar, ao invés de aprender para pensar, 
para refletir, inclusive sobre a pragmatização da relação professor-aluno e também de sua formação.

Ao argumentar sobre a necessidade de "prática”, queixam-se dos cursos de formação, considerados “teóricos”. Estes são feitos de equívocos também no que se refere à relação teoria-prática, uma vez que a primeira é entendida como instrumento da segunda. Os equívocos estão presentes na própria escolha das teorias ensinadas: evolutivas e cognitivistas do desenvolvimento humano que, além da concepção de psique que contêm, pressupõem um trabalho individual em sala de aula. Nota-se, dessa maneira, que os formadores mantêm a mesma relação de instrumentalidade com a teoria. A psicologia, neste sentido é o instrumento que pode garantir a eficiência pedagógica.

O relato de Nancy ilustra que, apesar de saber da impossibilidade de ser uma professora particular para cada aluno, seu pensamento e suas ações são orientados por uma concepção que supõe o trabalho individualizado:

Por isso que a teoria é diferente da prática, porque você precisaria dar atenção mais individual, coisa que você não consegue.

Assim, toda relação estabelecida com os alunos e, conseqüentemente, com o sucesso e com o fracasso na aprendizagem, tem como pressuposto a possibilidade de atender individualmente cada um deles. Se isto não ocorre - e é claro que não - buscamse culpados para o alto índice de não aprendizagem. Ora a incapacidade é atribuída ao professor, que não consegue transportar as teorias do desenvolvimento para sua sala de quarenta alunos, e ora ao próprio estudante, que não tem sucesso, apesar dos inúmeros esforços do professor.

Neste sentido, ao falar sobre teoria e prática, os depoentes tratam de suas condições de trabalho e, portanto, do fato de não conseguirem exercer o magistério em meio a classes necessariamente heterogêneas. Como não dão conta de atender individualmente cada aluno, mesmo acreditando que esta seria a melhor solução, têm ações que visam a homogeneizar e a controlar a sala de aula, o que se torna impraticável.

Por tudo isso sofrem. Na tentativa de resolver suas angústias, vislumbram o atendimento individualizado, mesmo que saibam de sua inaplicabilidade na escola 
pública - espaço de aprendizagens coletivas. Querem encaminhamentos dos alunos que não aprendem, mas querem parcerias dentro da instituição na qual trabalham. Criticam a teoria e almejam a prática. Em meio à vivência de uma psicologia tradicional, classificadora, pragmatizada pela psicopedagogia, os depoentes estão falando, com muita propriedade, dos males vividos pela escola pública e de suas repercussões no diaa-dia escolar. 


\section{CAPÍTULO VII - O CENÁRIO DA IMPOTÊNCIA: como vivem os professores na escola}

Eu me sinto, às vezes, numa luta solitária [Márcia].

A luta solitária de que fala Márcia também é sentida pelos outros depoentes. O que se vive na escola pública hoje são o descaso e o desmantelamento do ensino para o povo. Solicitados a falar sobre a psicologia em sua formação, os professores tratam da situação atual da educação escolar pública e de seus sentimentos, dificuldades e sofrimento cotidianos. Apesar de não ter sido foco desta investigação, a atual realidade da escola foi o tema mais tratado pelos depoentes. Ele esteve presente ao longo dos depoimentos, desde as entrevistas iniciais não gravadas, mas mais fortemente na discussão do depoimento com o entrevistado. Neste momento, ao comentar o seu relato, após ter lido a transcrição, os professores falaram quase que exclusivamente sobre as dificuldades encontradas em sua profissão e sobre os sentimentos decorrentes. Em alguns momentos, têm consciência das causas que levam a escola ao caos, fazendo duras críticas e apresentando propostas importantes para a melhoria do ensino público; em outros, descrevem situações com precisão, embora não tenham clareza dos reais motivos que as produzem.

O acúmulo de funções é um tema bastante comentado pelos depoentes. Assumiram tarefas de enfermeiros, dentistas, secretários de escola, inspetores de alunos, pais, mães, conselheiros. Tratam de doenças, dão orientações e conselhos para alunos e pais, fazem diagnósticos, carregam no colo as crianças com deficiência física, acompanham no recreio aquelas com deficiência mental, fazem teste de acuidade visual. O professor é um “faz tudo”. Wanda comenta as atribuições dos docentes que dão aulas para as séries iniciais do ensino fundamental: 
É pior, porque eles [os alunos] têm dor de dente, eles fazem xixi na calça, às vezes eles fazem cocô na calça. Você tem que providenciar a limpeza da sala de aula, você tem que tentar amenizar o dente da criança. Antigamente a gente podia dar remedinho, agora você não pode dar mais nada, não se dá mais remédio nenhum. Então você tem que chamar alguém da secretaria, você tem que procurar alguém, você não pode largar a classe sozinha também. Pra chamar a mãe, avisar que está passando mal, outro que de repente começa a vomitar, é você que tem que recorrer, ver o que vai fazer. Tem uma série de coisas. Tem os paraplégicos, por exemplo, que eu carregava no colo porque a escola não é adequada. Eu tive criança, uma menina, não esqueço mais, que o pai à noite pegava a menina e a menina quando chegava no dia que ele pegava, no dia seguinte ela tinha aquele desmaio na sala de aula. Acho que nervoso, sabe? Não sei se ela não tomava o gardenal direito lá, não sei. Como é que chama aquilo? É desmaio? Que treme assim, que baba. Que depois ela chega a dormir um pouco e aí ela acorda desorientada. Já passei por isso também. Acorda desorientada, você não sabe bem o que fazer, você vai atrás dela, ela não sabe bem aonde ela está indo. E você fica sabendo por outros que o pai chega bêbado e pega a menina. Ah! Sabe? Não é fácil! É muita coisa. A saúde também fica por conta nossa. Tudo. Você é pai, você dá conselho, nasce um irmãozinho mais novo, a criança fica rebelde, até você descobrir que é porque nasceu um irmão mais novo [...] Eu acho sinceramente que professor tem acúmulo de cargos. Você é pai, você é mãe, você já é tudo. Você é o dentista. Você é tudo [...] Por menor que seja a escola, um dentista, um psicólogo, um assistente social. Não pode deixar a gente abandonada assim. A gente tem que ser tudo. Tem que ser tudo. Eu vejo elas [as professoras das séries iniciais do ensino fundamental I] reclamando no período da tarde: "Pôxa, a gente tem que fazer teste de acuidade visual! Com quarenta alunos na sala!”. Foi muito complicado, sabe? Depois teve gente que teve que fazer o re-teste, porque não deu certo. Elas ficaram loucas. Elas chegam na sala de professores exaustas, nervosas, cansadas, você percebe a aflição delas. Antigamente, a gente não fazia. Uma pessoa subia, chamava alguns alunos, descia, fazia, mandava eles de volta. Levava outros alunos, fazia. E isso era sala por sala. Não tirava a professora da sala. Já teve época que a gente descia com aluno para escovar dente. Para dar remédio, vermífugo, flúor que eles mandavam. Agora eles não estão mandando mais, mas eu peguei muito disso, há anos atrás. Então fazia o bochecho, punha todo mundo colherada do flúor na boca na hora certa. Ficava bochechando. Aí eu contando no relógio, a hora certa. Depois passava o balde, todo mundo ia cuspindo lá dentro. Tinha 
uns que vomitavam, que tinham nojo, sabe? É muita coisa que não é função do professor. Seria do dentista passar flúor nas crianças. Ir chamando uma sala por dia, passar o flúor, não é?

Sandra queixa-se de ter de assumir o papel de psicólogo:

E exigir também que a gente resolva os problemas psicológicos, acho que já passou demais da nossa formação. Não só da formação, acho que nem é o nosso papel.

Como se não bastassem todas as adversidades da profissão, a nova política de inclusão dos alunos com necessidades especiais chega para acabar com o que resta de ânimo:

É de impotência, o sentimento que dá é o mesmo que é passado pra gente, de um descaso, e que essas crianças vêm pra escola e que elas não estão sendo incluídas, estão sendo excluídas. Porque elas são deixadas de lado. Porque se você não tem equipamento nem formação pra trabalhar com elas, elas vão ficando de lado, não é? Quer dizer, isso é natural, até. Então, eu não sei, é um descaso mesmo. E eu não acredito nessa inclusão se não tiver uma formação antes. Não existem os "Sacs", as Salas de Apoio Pedagógico para as crianças com deficiência, também não existe. Então é difícil. Uma frustração. Simplesmente, frustração mesmo. Por quê? Não existe uma seriedade nessa proposta de trabalho da inclusão. Do jeito que está não vai ficar, não dá pra ficar. Porque acho que a médio prazo a gente não vai ver produto final nisso aí, essas crianças não vão ter um desenvolvimento. E a inclusão é isso: é saber trabalhar com essa criança, desenvolver essa criança. E a escola não sabe fazer isso ainda, não está preparada pra isso. Nem ela, nem a comunidade escolar, nem as crianças, nem os colegas, nada está preparado [...] E ainda as salas cheias. Se eu te falar que você tem um incluído em sala de aula e que se mantém uma sala de aula com trinta e cinco alunos, e falar que trinta e cinco alunos dá pra se trabalhar inclusão, não dá. Então, é difícil o trabalho. Você pega aí uma APAE, onde você tem o pai, a mãe da M. [uma de suas alunas com deficiência mental], por exemplo, te fala que o trabalho lá com as crianças são em seis alunos por sala. E você quer que com sala de trinta e cinco você trabalha inclusão? E sem a formação que o pessoal de APAE tem, por exemplo? São 
formados, tem preparação e só dão conta de trabalhar com seis em sala de aula! Então é tudo uma coisa que não dá pra acreditar na seriedade. Está longe de ser um trabalho sério. Primeiro você planeja, pra depois executar. As coisas acontecem ao contrário. Você já faz a inclusão sem os prédios estarem equipados, as pessoas estarem formadas, sem informação e sem formação [...] Pra acumular, ainda é dupla jornada de trabalho, os salários... O professor não tem tempo nem pra se formar. E se ele trabalhasse numa escola séria, teria a manhã, a noite pra ele ir se formar, fazer um curso de mestrado, qualquer coisa. Uma especialização. Mas o professor, ele tem jornada em duas, três, quatro escolas pra poder complementar sua renda, e ele não trabalha a sua formação porque não tem tempo pra fazer formação, não tem nem tempo, nem dinheiro pra fazer a formação, as duas coisas. Então acho que é uma questão das condições de trabalho. Melhorar o salário do professor pra que ele possa fazer a sua formação, garantir a sua formação, planejar melhor sua aula. Quer dizer, o cara nessa situação, ele não planeja aula, ele não consegue trabalhar com o curso. São muitas variáveis aí que contam. Não é só a questão da formação. Mas não é fácil. O que a gente percebe é um trabalho espontaneísta dos professores, uma coisa bem assim, vai acontecendo no dia-a-dia, sem nenhum planejamento [Antônio Carlos].

Eu não fui formada pra ter alunos com deficiência mental, que agora tem a inclusão, você sabe disso. Eu não fui formada pra isso. Fui formada pra lidar com crianças normais. Agora tem esse problema aí, mas como eu estou com adultos, já não está me atingindo tanto, porque os que eu tenho que são problemas de não poder escrever, que tem o braço duro, porque levou um tiro na cabeça, porque não anda direito. Mas não aqueles problemas de Down, que tem na escola e que a professora precisa lidar com todos e mais aquele. Eu tenho certeza que ela não foi formada pra isso. Então, da onde vem isso? De cima. É muita preocupação [Wanda].

E então é por isso que essas salas especiais do estado, entre aspas, que lida com o aluno conforme a sua deficiência, eu acredito que ela dê mais resultado do que essa inclusão que a prefeitura está querendo fazer. Colocar todos esses alunos com esse monte de dificuldades, pra conviver com os outros normais, entre aspas, pra ter resultado. Não tem resultado, não tem como ter resultado. Pode até ter resultado na área de sociabilizar a criança, mas de aprendizagem, de melhorar o seu comportamento, isso não [Sandra]. 
Ao comentar as propagandas do governo municipal que apresentam a escola preparada para receber os alunos de inclusão, Antônio Carlos denuncia:

Nada está pronto pra receber as inclusões. Você pega os prédios públicos que têm rampa. Aqui não tem rampa, por exemplo. Que inclusão é essa que fala que os equipamentos e os profissionais estão prontos? Nem o professor teve formação e nem os equipamentos da prefeitura estão adaptados pra inclusão. Você não tem elevadores pra alguns deficientes. E você não tem nem rampa, que é a coisa mais simples, aqui não tem rampa pra subir pra sala. Aqui você não tem nenhuma sala lá embaixo. E o aluno você tem que carregar, entendeu? [...] E aparece um Céu $u^{44}$ lá no fundo [da propaganda], e só o Céu está equipado pra isso, que tem elevador e que tem rampa. Ah, só o Céu, que não é nem um por cento das escolas, são uma dúzia de Céus, e são mais quase trezentas escolas. Então é um absurdo falar que o Céu representa a rede no trabalho. E a formação do professor que está em Céu é a mesma do que está aqui. Nem existe formação específica pra inclusão. E nem professores e nem equipe técnica estão preparados pra inclusão. Nem o diretor teve formação pra isso, e nem o coordenador ele está preparado pra propor projetos nessa área de inclusão, nem nada. Ninguém está preparado. Não é só o professor não. Nem coordenador, nem direção, nem equipamentos estão prontos pra isso.

Por isso querem respaldo, subsídio, apoio pedagógico, profissionais com quem possam dividir a sobrecarga de trabalho:

A escola carece de todo um trabalho de coordenação pedagógica um pouco mais consistente [Maristela].

Antônio Carlos fala novamente sobre a inclusão dos alunos com necessidades especiais:

E a gente devia parar. A escola deveria parar e repensar tudo isso daí. A gente deveria fazer uma avaliação de como a gente se encontra, e o que deveria ser feito. Que

\footnotetext{
${ }^{44}$ Centro de Educação Unificado.
} 
soluções, que rumo tomar? [...] E não achar que vai resolver tudo de imediato. O que falta só é troca de informação, troca de conhecimento, parcerias para capacitação dos professores. Esses professores que já têm uma formação nessas entidades [APAE], que já trabalham com deficientes poderiam estar participando da formação ou dando depoimentos.

Esse professor reivindica apoio em vários setores que abrangem o seu trabalho:

Deveria ter médicos, dentistas dentro da escola. Ter um suporte mais apropriado, que já houve anteriormente na escola, e que não existe mais esse suporte. Eu acho que a escola não é só o profissional, o professor. Então eu acho que deveria voltar a ter trabalho com profissionais da saúde, com o próprio psicólogo. Eu acho que isso ajudaria. A escola formar um banco de dados. Mas ele [o professor] ter a bibliografia, ter aonde buscar a informação que ele precisa para resolver a questão. Tem que partir de uma política séria de educação. A gente tem aqueles alunos que têm deficiência do processo de aprendizagem. Mais lentos, que não conseguem aprender dentro do mesmo período que o outro aprende. E nem as salas de apoio pedagógico todas as escolas têm. Ter uma estrutura apropriada.

Nancy deseja o apoio da psicopedagogia e da psicologia:

Eu acho que eles deviam ter uma psicopedagoga e uma psicóloga efetiva dentro da sala de aula. Não tem um, dois coordenadores por escola? Devia ter um psicólogo. Aliás, há muito tempo atrás, tinha orientadora educacional que fazia esse papel do psicólogo. E era muito bom, muito bom.

Wanda também comenta a necessidade de apoio:

Outro dia estava uma briga lá embaixo por causa de um aluno. A professora está pedindo licença porque não agüenta, por conta de um aluno, a sala. Eu falei: "Escuta, mas onde tem assistente social? Por que não chama a assistente social? Chama, para ver o que acontece na casa desse menino. Por que esse menino está assim?” [...] Tem um problema desses - como esse menino - que a professora não agüenta dar aula. 
Imagina! Ver onde ele mora, como que é a vida dele. Ajudar um pouco. Então precisava ter também assistente social, psicóloga, dentista, sabe? A escola precisa de tudo isso [...] Eu acho que a psicóloga é importante demais aqui dentro, mas uma assistente social para o lado de fora também era necessário.

Queixam-se, também, das classes superlotadas e heterogêneas e da necessidade de trabalhar individualmente com os que não aprendem, embora as condições de trabalho tornem inviável o ensino individualizado. Nesse contexto, cobram a recuperação paralela, prevista em lei, ou solicitam a ajuda de outro profissional, como auxiliar de classe:

Teria que ser um atendimento individualizado também para aquele aluno [que não aprende]. Mas se ele tivesse um atendimento individualizado, mesmo na área de aprendizagem, se ele tivesse uma recuperação paralela, se ele tivesse uma pessoa na escola que o ajudasse individualmente, também iria resolver parte do problema [...] Independente de ser psicólogo ou não. Então as nossas dificuldades estão muito além de ter ou não ter um psicólogo na escola. A gente não tem nem uma pessoa que dê uma recuperação paralela para um grupo pequeno de dez alunos, que não é nem individual, são pequenos grupos. Imagine atendimento individual, que seria o caso deles [Sandra].

E a dificuldade é a quantidade. Que são esse ano trinta e cinco, mas normalmente são quarenta, e você tem que atender os quarenta. São quarenta realidades diferentes, quarenta situações diferentes e às vezes é difícil de você lidar com tudo [...] Não acho que só a formação melhoraria. Acho que é lógico que faz uma super-diferença a formação do professor. Mas eu acho que não resolveria. Eu acho que precisaria ter uma pessoa a mais - uma no mínimo - de fora. Até uma auxiliar de classe, que é coisa que tem nas escolas particulares, acho que ajudaria muito. Porque eu imagino assim: se eu tivesse uma auxiliar e ela pudesse sentar e ficar corrigindo as lições, eu ficaria o tempo todo aqui com os meus alunos. E eu tenho que fazer os dois papéis. E se tivesse uma outra pessoa dentro da sala, ajudando, acho que seria ótimo. Nem precisava ser psicólogo, precisava de uma auxiliar pra ajudar nas lições, e eu já teria mais tempo de ficar com eles [Márcia]. 
Nas condições atuais de trabalho escolar, cabe aos professores fazer diagnósticos psicológicos dos alunos que apresentam problemas de aprendizagem ou de comportamento na escola. Sandra critica esta atribuição:

O professor não é especialista nessa área de psicologia e nem deve ser, e nem tem que ser, e eu acho que nem tem que ser exigido isso. O que pega é que cada vez mais está sobrando essa parte pra escola resolver. Não o professor sozinho, a escola resolver. Nós temos alunos com déficit de atenção, com hiperatividade, com problemas de locomoção, todas essas áreas e a escola que acaba tendo que resolver esse problema. $O$ aluno tem que aprender, independente de todas essas deficiências dele ou essas dificuldades dele, ele tem que aprender. E o professor tem que fazer o que nessa situação? Ele tem que ser um psicólogo formado? Ele tem que ser um neuro formado? Não, né? Acredito eu. Então, lógico que os professores mais interessados vão atrás, a Márcia foi atrás. Ela tem uma aluna com síndrome de Down, e ela foi atrás, foi na APAE e quer saber como é que lida com a M. [aluna com deficiência mental], o que ela tem que fazer. Eu não vou. E os meus alunos que eu tenho lá, que eu acredito que tenham alguma dificuldade em alguma área, eles coitadinhos vão ficando lá comigo, eu vou dando atenção, fico mais do lado dele, vou elogiando os seus pequenos avanços, essa é a minha parte. E o pai vai atrás do médico. O que ele precisa, a gente contata, chama, conversa, coloca as dificuldades que sente em sala de aula. E aí o pai vai atrás, conforme o seu interesse.

A descaracterização da escola, enquanto instituição de ensino, e não só do professor como educador, também aparece na fala de Sandra:

Agora, por outro lado, eu acho que sobra pro professor muita coisa pra ele resolver. $O$ professor hoje ele tem que ensinar, educar, até a coordenadora estava falando que a gente tem que ensinar o aluno a não estar brigando na hora do recreio. Então eu acho que muita coisa está sobrando pra escola. E essa coisa da psicologia também cobrar do professor, ou exigir, ou esperar do professor que ele resolva os problemas do aluno, os problemas psicológicos dele que são muito profundos, eu acho que exige demais. 
Apresenta como solução o aumento do número de horas que o aluno deveria passar na escola, a fim de que pudesse fazer uma série de atividades desvinculadas do ensino; ou seja, sua proposta não passa pela crítica a uma política que atribui à escola funções que não são as suas e a descaracteriza enquanto instituição escolar:

Esse aluno deveria ficar aqui oito horas, uma hora passar por terapia, outra hora brincar, outra hora vamos fazer não sei o que lá, e mais quatro horas ou mais três horas de conteúdo. Talvez pensar a escola como um todo. Já que cada vez se exige mais também da escola [Sandra].

As críticas às condições de trabalho e à situação atual das escolas dizem respeito também às crianças que passam anos na instituição e continuam analfabetas:

Porque na terceira-série tem criança que não sabe ler e escrever. Então você tem que alfabetizar. Você tem que dar uma aula geral para todos os alunos que já sabem ler e escrever, dar todo o conteúdo da terceira-série, e se dedicar àquele que não sabe [Nancy].

Para explicar a presença, na terceira-série, de crianças que não sabem ler e escrever, Márcia comenta a diferença existente na alfabetização de crianças nas escolas particulares e públicas:

O que eu dou aqui [na primeira-série da escola pública] é o que eu dava na pré-escola particular. Que é uma pena. Os livros de primeira-série são muito difíceis. Porque eles [os alunos da escola pública] vêm com uma defasagem muito grande. Na sondagem diagnóstica que eu fiz, eu tenho quatro alunos que estavam sabendo escrever legal, que já realmente sabem escrever, sabem ler alguma coisinha. Sabem contar, sabem quantidades. O resto deixa tudo em branco, não conseguem fazer nada nas sondagens. Então eu converso com esses que sabem, que eles vão ter que ter um pouco mais de paciência, que eles vão me ajudar, que eles vão ajudar os que não sabem ainda, $e$ quando der, eu vou dar atividades complementares pra eles. Mas muitas vezes não dá. E eu sei que eles atingem. Eu gostaria de dar uma coisa que tivesse uma continuidade, uma lição um pouco mais difícil pra eles, mas não dou conta. Se não dá pra corrigir, então eu prefiro não fazer. Não gosto de fazer coisa pra não corrigir. 
Wanda, ao mostrar a avaliação de um de seus alunos, denuncia a situação do ensino de jovens e adultos:

Olha aqui: foi colocado [o aluno] na segunda-série. Não sabe nem ler, ele não conseguiu ler, não conseguiu fazer nada. Eu simplesmente falei pra ele: "Você precisa pôr o seu nome, a cidade onde você nasceu e na última linha, o seu endereço”. Nem isso ele fez direito, ele fez tudo aglomerado. Ele não sabe ler, está na segunda-série. Pra ele também é difícil voltar pra primeira, porque ele fez primeira em algum lugar e veio pra cá. E aqui, matricularam na segunda, como se ele já tivesse feito a primeira, mas ele não sabe nem ler. E como é que eu posso ter uma classe de segunda e terceira-série e com alunos tipo primeira junto? Eu não agüento! E tem salas fechadas à noite! Por que não dividir a segunda e a terceira-série? Por que não? E colocar os de primeira em primeira, que tem a sala, e os de segunda e terceira divide. Não interessa se vai ficar trinta alunos em cada lugar, ao invés de ficar cinqüenta numa sala só. A aprendizagem seria até melhor com menos alunos. Separasse segunda de terceira, tem mais de três ou quatro salas fechadas à chave à noite! Revolta, entendeu? Fechou, vem do $N^{45}$ [a determinação para fechar], que tem que ter as salas com mais de trinta e cinco alunos. Só que aí a minha classe está com quarenta e seis, não daria trinta e cinco. Mas, abre inscrição, chegam mais alguns. E mesmo que não fique com trinta e cinco, que fique com vinte e cinco! Você está ajudando vinte e cinco, você vai fazer um trabalho bem feito com vinte e cinco! Está certo? Pra que deixar a sala fechada e gente sem emprego? Agora mensalão é bom, né?

Nancy questiona as teorias educacionais que consideram a alfabetização como um processo que dura oito anos:

A gente tem um índice muito grande de crianças analfabetas, que passam por conta desses ciclos, com todo esse sistema novo da prefeitura, que a criança vai passando, ela só reprova na quarta e na oitava. O que acontece? A criança que não se alfabetizou na primeira, passa pra segunda sem alfabetizar, pra terceira, chega na quarta, uma repetência enorme dessas crianças que não foram alfabetizadas. E se você pega essas

\footnotetext{
${ }^{45}$ Núcleo de Ação Educativa, órgão pertencente à Secretaria de Educação da cidade de São Paulo.
} 
crianças numa quarta-série não alfabetizada, ela é muito bloqueada! Eu, por exemplo, que sou professora de terceira-série, eu tenho aluno que não consegue aprender as vogais, o "a, e, i, o, u”, não dá, não vai, não consegue. Então, a gente não sabe o que faz com essas crianças. É um bloqueio. O porquê desse bloqueio, eu gostaria de entender [...] A gente fica alfabetizando. A gente pega cartilhas, pega métodos e começa a alfabetizar dentro daquilo que a gente sabe. Mas a gente vê que não vai além. Muitos até dão alguns passos à frente, mas não é aquela coisa de sair totalmente alfabetizado, leitura corrente, escrita. Não, não chega a isso. Dão pequenos passos à frente. Isso realmente é um problemão pra gente. E agora, mais do que nunca, porque antes as crianças repetiam - repetiam não sei quantas vezes a primeira-série, repetiam não sei quantas a segunda - quer dizer que, de tanto fazer, tanto fazer, iam pra terceira alfabetizadas. Agora não. Até se está pensando em a criança fazer pelo menos duas vezes a primeira-série. Porque se diz que a criança é alfabetizada até a oitava-série, coisa que eu não concordo. Eu acho que é impossível uma criança ter oito anos pra ser alfabetizada. Alguma coisa errada deve estar aí no caminho. Que antes as crianças eram alfabetizadas na primeira-série e agora se estendeu até a oitava, imagina! Uma criança que entra com sete anos, com quatorze ela ainda está no processo de alfabetização! Alguma coisa está errada, eu não sei. Mas, os teóricos dizem que não, que é assim, sei lá.

Em outro momento, Wanda faz críticas às escolas construídas pela prefeitura de São Paulo:

A criança passa muito tempo, o adulto também, passa muito tempo aqui, sabe? E pelo que estão falando vai passar mais. Então precisa melhorar. O que adianta fazer o Céu? Uma escola na região, maravilhosa, que tem de tudo, diz que tem tudo, não sei, mas quem também dá aula lá não quer ficar, acaba voltando. Não sei bem como é que é. Já visitei, achei lindo, maravilhoso. Mas, não sei, parece que não funciona muito bem. Funciona bem é a piscina aquecida, sabe? Essa parte funciona bem, em final de semana.

Essa depoente fala indignada sobre os motivos que levam as crianças a não saírem alfabetizadas da primeira-série como antigamente: 
Aconteceu que mudou o governo e parece que o governo gosta que as pessoas não sejam muito alfabetizadas. A impressão que dá é esta. Porque vêm métodos diferentes que a gente tem que aplicar, a gente não sabe direito, a gente é quase cobaia com isto, como a gente foi com aquela tal da Emília Ferreiro, que ela fazia com cinco, seis alunos na classe, no máximo doze e a gente com quarenta tinha que estar fazendo como ela fazia. A partir de que apareceu Emília Ferreiro esse pessoal não foi mais alfabetizado como era antigamente, porque você tem vergonha de dizer pro seu colega que você vai silabar. E os cursos que você faz daqui pra frente, nenhum deixa você silabar. Isso é do passado, isso não existe mais, mas ele é forte. E eu lembro muito bem que no meu tempo, no ginásio tinha "Gramática do Segala”. Eu sabia a gramática inteira. Eu sabia ler, eu adoro ler. Se chegar numa reunião e falar assim: “Quem gostaria de ler?”. Eu leio. Não tem problema. Vê se algum aluno gosta? Está certo, a vida mudou, minha mãe ficava na minha casa, me dava todo apoio, meu pai só que trabalhava. Agora, não. Eles têm a mãe e o pai trabalhando, eles são abandonados. Eles ficam sozinhos, a maioria deles, não tem aquele auxílio em casa mesmo. Perdeu-se isso. Mas, aquela parte da silabação, eu ainda acho que faz falta e eu tenho vergonha de falar pra alguém que às vezes eu faço uma silabação na sala. E faço mesmo. Só que eu fico quieta, não falo, porque é vergonha falar, não existe mais isso [...] Então eu acho que a culpa maior é dos que vêm de cima mesmo, dos órgãos acima da gente que vêm implantando coisas fora de hora, sem embasamento nenhum, como começou com a Emília Ferreiro, sabe? A gente tinha quarenta alunos na classe, eles queriam que a gente aplicasse, sendo que eu fui numa das primeiras reuniões, nem eles sabiam o que falar pra gente, como fazer, no auditório lá do $C O N A E^{46}$, todo mundo sentado em poltrona, como se fosse a novidade! Tudo novo! Eu lembro, fui lá, não entendi nada! Porque eles também não sabiam explicar nada e a gente caiu nisso de cobaia. Agora vem esse silábico, présilábico, silábico-sonoro, pré-silábico alfabético, sei lá. Eu sei fazer isso de tanto curso, mas não adianta, porque eles querem que você trabalhe em grupo de dois alunos, por exemplo. Você põe dois alunos juntos pra estarem fazendo a mesma atividade. Só que a classe fica dividida. Você não consegue sozinha ver todas as duplas na mesma aula.

\footnotetext{
${ }^{46}$ Coordenadoria dos Núcleos de Ação Educativa, órgão pertencente à Secretaria de Educação da cidade de São Paulo.
} 
A falta de recursos humanos e materiais nas escolas; as situações de violência; o abandono das crianças nas salas de aulas em virtude da progressão continuada; os baixos salários; a dedicação do professor e o descaso dos órgãos educacionais superiores são temas abordados com freqüência pelos depoentes:

Até o meu marido outro dia comentou: "Ai, por que você não abandona educação, não vai pra outra área? Ai, porque você ganha muito mal, você se dedica e ganha...”. Eu falei: "Ai, porque eu dediquei minha vida toda estudando na parte educacional e vou largar tudo e começar outra...”. Ah, eu tenho um certo receio. Até tem outras coisas que eu gostaria de fazer, mas eu não investi nessas coisas, eu investi em educação [Márcia].

Tinha dentista. Aqui sempre teve a sala do dentista. Quando eu comecei, tinha uma dentista. Essa sala foi fechada, acabaram com tudo aí, não sei, sumiu a sala da dentista. Porque aqui você tem muita dor de dente. Então qualquer problema já ia pro dentista. Sumiu. E lá no outro não [em outra escola que trabalhou], lá funcionava tudo. Eu não sei se é por conta da Delegacia de Ensino, que mudou. A minha delegacia agora é uma, lá era outra. Aquela delegacia acho que favorecia mais as escolas. Então por ela ser mais carente [a outra escola], eles davam prioridade pra ela, pra aquela escola. Alunos super carentes. Um lugar super perigoso, onde o helicóptero passava da polícia, com o guarda pra fora assim, no pátio, sabe? Procurando. Tinha um morro que a gente subia pra chegar lá que chamava, como diziam, o Morro do Piolho. Porque a criançada subia da favela para estar indo pra escola. Não havia uma vez que, quando chegava de manhã, não tinha polícia e já naquele mato tinha corpos. Eles falavam presunto, que tinha presunto. E era super perigoso. Eu deixava o carro na rua, então tinha uma igreja de crente bem do lado, eu fiz amizade com a dona da igreja lá, quem tomava conta da igreja, ela deixava eu guardar o carro dentro da igreja. Eu acho que também pode ser por isso: pelo local ser mais perigoso, mais carente. Mas as crianças eram bem mais amigas. Bem mais amigas. Naquele frio danado, traziam a sandália de dedo, você tinha que pegar e enrolar jornal no pé. Deixava, sabe? Não é como aqui [Wanda]. 
Eu vejo a não-retenção como uma coisa boa. Eu não sou contra. Só que da forma como está, as crianças abandonadas nas salas de aula, sem ter nenhum trabalho com elas fora de sala de aula, sem ter um projeto na escola... Até que boa intenção existe. O que não existe é realmente um projeto trabalhando com esses alunos com deficiência de aprendizagem, isso daí não tem na escola [Sandra].

Não adianta só culpar a formação do professor. Se não resolver todo esse caos que a escola está... Eles querem todas as crianças na escola, mas não tem! Ou tem, até tem. Então vamos colocar 45, 40. Numa sala que comporta 35. Eu tenho 34 alunos. Uma sala gostosa esse ano. Mas as quartas-séries estão com 40, 41, 42. Isso não é aqui, isso são todas as escolas. É estado, é prefeitura, tudo na mesma situação. Professor falta, não tem substituto. Professor fica doente, não tem com quem fique. Então, o que acontece? O governo nem sabe o que está acontecendo na verdade na escola. Só sabe o que está acontecendo na escola é quem trabalha na escola, quem está envolvido com a escola. Agora se o diretor reclama pra delegacia de ensino, pro NAE, CONAE, sei lá pra onde, por falta de professor, ele vai falar que ele não tem. Se esse órgão vai pro superior dele, pra Secretaria de Educação, também vai falar que não tem. O que resolve? Além da formação do professor, que pode ser até mesmo deficitária, eu acho que também são as condições de trabalho que nós temos na escola. E esses alunos, coitados, que vão passando, passando, passando, sabe o que sobre pra eles? A maioria, não são todos, eles são indisciplinados. É o que sobra pra eles: é ser indisciplinado [...] Tem aluno na quarta-série hoje que é a quarta vez a quarta-série dele. Então em vez dele estar se formando na oitava, ele ainda está na quarta-série. E parece que ele também não entende que a vida dele vai ficar assim, se ele não se despertar pra aprender. Aí vem a questão da saúde: por que ele não aprende? É a parte psicológica, neurológica? $O$ que está acontecendo com esse aluno? Não é só o professor que é culpado. Sabe por quantos professores esse menino passou? Por oito professores. Não é possível que oito professores não davam conta de alfabetizar esse menino! Então o problema está em alguma coisa nele já. Não é possível que nenhum professor não teve capacidade para alfabetizá-lo [...] Agora, onde é que está a recuperação paralela prometida na $L D B^{47}$ ? Não existe. Cadê o professor pra pegar esse aluno fora de sala de aula? A recuperação paralela que nós temos é na sala de aula junto com os 30, 40 alunos. Não existe uma coisa separada só pra isso. Então se o governo também não dá

\footnotetext{
${ }^{47}$ Lei de Diretrizes e Bases da Educação Nacional.
} 
condições melhores de trabalho, infelizmente a situação vai ficar assim mesmo [Sandra].

Então, o pessoal pode até falar: "Ah, a sua aula não está muito boa”. "Então está bom. Então o que a gente faz pra melhorar?". "Planta bananeira", que nem diz uma professora. Uma vez ela falou assim: "A gente tem que seduzir o aluno". Vou vir de baby doll pra seduzir o aluno! Porque essa história de seduzir aluno fica engasgada na garganta da gente. E quando vem essa história de seduzir o aluno eu falo assim: "Gente, na nossa época a gente tinha que ser seduzido pra aprender, pra prestar atenção na aula, pra fazer a lição, pra copiar da lousa, tem que ser seduzido?”. Essas palavras ficam entaladas [Sandra].

E eu vejo professoras muito dedicadas, muito interessadas. Pessoal leva trabalho para casa, sai carregado, chega carregado todo dia, cheio de coisa, e prepara coisa para os alunos, e às vezes ficam em horários fora da aula dando lição, dando coisas extras para aluno que tem dificuldade, chama pai, a gente chama pai quase todo dia pra gente atender. Então, eu acho o corpo docente interessado, mas a gente fica meio sozinho mesmo. Eu não acho que a formação, melhorando a formação, se não melhorasse essas outras condições de trabalho, eu acho que não dá conta mesmo desses problemas [Márcia].

Eu não fiz a Psicopedagogia por causa da escola. Eu fiz porque eu queria, na verdade, ampliar as minhas possibilidades de trabalho mesmo. Porque às vezes enche o saco. Tem dias que dá vontade de sair da escola, sabe? De fazer outra coisa, porque é muita dor de cabeça, pra tudo quanto é lado. Que nem essa semana, sexta-feira eu vou à APAE, e aí já hoje a mãe da M., que é a menina Down, veio falar comigo. Aí a menininha bateu na diretora, bateu no pessoal da secretaria, e quer bater na coordenadora. Gente, é muito pepino! Então, ela veio falar comigo, tem que ser feito um trabalho com essa menina de integração. Eu falei pra ela: "Eu vou à APAE sexta-feira, e vou conversar lá", porque não é uma coisa que eu tenha experiência. Eu nunca trabalhei com síndrome de Down. Então, às vezes é muita coisa, e muita dedicação, sabe? E eu fico pesquisando material pra essa menina, tudo. Às vezes eu penso assim, hoje eu estava refletindo, eu falei: "Será que eu estou deixando até os outros um pouco de lado e acabo dando muita atenção pra essa menina?". Porque como é um caso de 
inclusão, fica muita coisa concentrada em cima dela. Diretora vem perguntar dela, a coordenadora, o pessoal da delegacia de ensino vive mandando formulário para eu preencher. É como se eu tivesse que ser impecável com essa aluna, entendeu? [...] É muito pepino, muita coisa no dia-a-dia que desgasta. Desgasta porque não tem apoio. Eu estou indo na APAE porque eu quis, porque eu liguei, porque eu fui procurar, ninguém me falou nada. E então, só o que vem falar é cobrança. Te cobrar: "Ah, que tipo de trabalho está sendo feito na hora do recreio pra integrá-la no recreio?”. Eu não fico no recreio. Então é complicado. Só se eu ficar com ela [Márcia].

Em síntese, falam de solidão, desânimo, infelicidade, frustração, impotência, que a recente política de inclusão, nos termos em que foi feita, só fez agravar:

Eu me sinto numa luta solitária mesmo. A família não ajuda. Aqui na escola até tentam conseguir recuperação paralela, de tirar esses alunos e eles ficarem com outra professora, só que nunca conseguem a professora, nunca vem professora. Até conseguiram, mas aí disse que ela não ia ganhar nada. Se ela quisesse ia ser voluntário. É lógico que não quis, né? Então eu fico angustiada de chegar no fim do ano, sempre tem estatisticamente o mesmo número - é dez, doze - que não conseguem ler e escrever no final do ano. E também tem muitos que entram no meio do ano. Por exemplo, na minha sala tem três vagas. Porque a classe é de trinta e cinco, eu estou com trinta e dois. E esses três não entram. Eu preciso que entre no começo do ano, já fique lá. A lista de espera lotada, eu não sei quando que eles chamam essas crianças. Às vezes, acontece de entrar com eles em novembro, dezembro. E aí não tem o que fazer também. Então eu ficava muito mais frustrada no começo. Aí eu fui me convencendo de que eu não posso fazer tudo sozinha. E até falava isso na terapia, que eu ficava angustiada, que eu ficava triste, mas agora eu já estou mais acho que, entre aspas, acostumada com essa situação, sabe? Todo o ano se repete, em todas as salas. Que a gente conversa com as colegas, e todas têm esse número. Umas têm oito, outras têm dez, outras têm quinze. Mas é sempre mais ou menos um terço da sala que tem muita dificuldade de aprendizagem. E aí num grupo grande você não tem como sentar do lado [...] Eu acho que precisaria ter uma recuperação paralela mesmo. Mas quando acontece é com 
grupo de vinte alunos, eu acho grande vinte. Porque nunca conseguem a professora. A professora que se dispõe a fazer isso, ela tem que escrever um projeto, mandar lá pra delegacia de ensino, daí esse projeto precisa ser aprovado, pra ela receber. E aí é um horário fora do horário de aula, eles saem da sala - ou é antes, ou é depois do horário - e as mães têm que concordar, e tem muitas vezes que elas não concordam porque não tem quem traga [o aluno para a escola]. Porque a demanda é muita e quando tem é uma professora. Então é escolhida uma - acho que agora, por exemplo, seria no quarto ano, que é o ano que está dando mais problema, porque tem retenção. Eu acho que isso é uma medida que ameniza [Márcia].

A questão burocrática na escola pesa muito, é uma papelada que você tem que preencher e isso muitas vezes é irritante, porque não tem sentido algum. Porque muitas vezes o peso da exigência de você entregar um conjunto de papeladas ao final de cada semestre é muito maior do que a disposição das pessoas para acompanhar a aprendizagem do aluno: "vamos sentar aqui e vamos analisar esse aluno, aquele aluno, a organização da escola, como ela pode ficar melhor, como ela pode apresentar-se até com um sentido maior pro aluno, como ela pode ser mais agradável”. Isso irrita um pouco e desanima até. Mas, enfim. Eu tento fazer com antecedência, pra ir me irritando aos poucos [Maristela].

Mas, enquanto eu não formar a minha filha, eu não posso sair porque eu vou perder $R \$$ 500,00 a R\$ 600,00 me aposentando. Eu não posso perder esse dinheiro, eu não vou poder me aposentar. Eu vou ter quanto? Um ano e meio pra me aposentar? Com certeza eu vou ficar mais uns cinco, com certeza. Porque você vê, se eu tirei minha filha agora da faculdade, pra pôr ela pra trabalhar! Você vê qual é a minha situação! Você pensa que eu me sinto feliz? Não. E outra coisa que eu me sinto muito infeliz também: eu já sou $21 E^{48}$. Eu não tenho mais pra onde ir, eu não tenho mais pra que subir, eu não sinto vontade de fazer cursos, porque eu não preciso de pontuação mais nenhuma! Porque aquela vontade de fazer cursos pra você ser pontuada: "Ah! Vou ficar com a letra B! Ai, passei pra 19, 19B!”, entendeu? Eu já não tenho mais nada disso. Então, como eu fiz muito curso, como eu sempre fui muito esforçada, eu já estou no 21E bem antes de me aposentar. Eu não tenho mais pra onde correr. Eu falo, às vezes, pra quem eu

\footnotetext{
${ }^{48}$ Esta é a última pontuação que um professor pode adquirir ao longo de sua carreira na prefeitura de São Paulo.
} 
encontro: "Pô! Me chama pro NAE, me manda pro NAE", porque no NAE você vai ganhar um pouco mais, você vai trabalhar oito horas. Não tem incentivo. Eu preciso de incentivo de dinheiro, eu preciso, porque eu sou sozinha! E eu nunca tenho mais isso. Mas, graças a Deus eu estou enfrentando, devendo todo mês pro banco, mas enfrentando. Se Deus quiser, porque tem muitos atrasados sem esperança de que venham. Muito, tem muita taxa de $81 \%$ em cima de salário, de trinta e poucos que não chega nunca. E não tenho como subir. Aparece curso, eu penso assim: "Eu só vou gastar gasolina”. Eu vou deixar de ficar com a minha mãe depressiva lá em casa, que até gosto de sair, adoro fazer trabalhos manuais, por exemplo, é o que eu amo de paixão. É uma coisa que me faz bem. Então, às vezes eu não vou fazer, aparecem coisas eu não vou, porque eu vou gastar só. E os cursos da escola a mesma coisa. Daqui pra frente, se eu for, eu só vou gastar, eu não vou. E eu fiz o melhor curso que teve até agora, que faz quase dois anos, que foi o tal do PROFA ${ }^{49}$, que parece que voltou. Ouvi dizer que tem gente que está indo fazer à noite. Se fosse agora, eu dou aula à noite, eu não faria. Eu fiz com o meu carro, com a minha gasolina, indo lá no NAE, por força de vontade, e esses pontos que eu nem imaginava, já nem valeram mais. Mudei pro $21 E$ sem eles. Mas, eu fiz por vontade. Agora eu estou sem essa vontade. Eu não sei o que aconteceu, eu estou com o incentivo baixo [Wanda].

Mas a situação de vida do professor pode ser tão precária e contraditória, que ser professor de escola pública municipal pode tornar-se, apesar de todas as dificuldades, motivo de satisfação:

Eu já trabalhei de várias coisas na minha vida. Nada ilícito, mas eu já trabalhei de várias coisas: já fui recepcionista de pet shop, eu já administrei uma empresa, eu já fui secretária junior, eu já fui professora de inglês, já fui professora de culinária, já trabalhei em cozinha de restaurante. Então quando você não curte um trabalho, você acha que o salário não está bom, você acha que os benefícios não estão bons, você sai na rua e você procura uma coisa melhor pra você, alguma coisa que melhor te encaixa. E quando você acha essa coisa que melhor te encaixa, você abandona aquela que não te agrada. Eu saí de um salário de $R$ \$300,00 pra ganhar $R \$$ 800,00 agora. Esse salário me agrada. Só que quem saiu de greve ganha $R \$ 2.500,00, R \$ 3.000,00$. Então, pra elas

\footnotetext{
${ }^{49}$ Curso de alfabetização, oferecido pela prefeitura de São Paulo.
} 
se você tirar $R \$ 50,00$ a $R \$ 80,00$, que é o valor da falta na greve, não faz a menor diferença. Ela não vai simplesmente na manicure, na cabeleireira a semana que vem, ela vai na outra semana, acabou. Agora pra quem ganha $R \$ 800,00$, você tirar praticamente $10 \%$ do seu salário pra faltar um dia, é um negócio assim que... E você brigar por uma coisa que você está achando que é bom? Você concorda que não tem função? Tudo o que está na prefeitura hoje em dia me agrada: eu gosto de trabalhar aqui, eu gosto do sistema de trabalho, eu gosto da maneira com a qual eu recebo, eu gosto dos benefícios que eu tenho aqui e eu não vou conseguir sair daqui, por exemplo, e pegar um trabalho de meio período ganhando $R \$ 800,00$ ! Isso é surreal em nível de Brasil! Eu acho que, se alguma coisa me desagradar, eu não tenho que fazer greve, fazer piquete, sabe? Estou dando mau exemplo pros meus alunos, sendo anarquista. Nada de política, mas eu não acho que eu estou dando um bom exemplo. Se você parar pra olhar na televisão, por exemplo, esses dias teve um bando de professor aí, no outro estado, que tentou quebrar o Palácio do Governo. Foi todo mundo preso, teve desacato à autoridade. Espera aí, sou educadora! Eu não posso achar que é bonito desacato à autoridade. Se eu fizer isso, e еи aparecer na televisão, meu aluno no dia seguinte não vai me respeitar. Ele não vai respeitar a minha autoridade. Se eu desacato a autoridade é porque isso não vale a pena. Então, as pessoas não acham isso. As pessoas - essas que me viraram a cara - acham que eu furei a greve porque eu vim trabalhar. Eu acho que elas são obrigadas a me aceitar, do jeito que eu sou, assim como eu as aceito do jeito que elas são. E eu acho que se isso não vai ser agora, um dia isso será [Carla].

Para Antônio Carlos, a inclusão tem gerado um desgaste intenso do professor porque ele se sente impotente diante de uma situação para a qual não foi preparado:

Professor se depara com uma questão nova [a inclusão] e não está preparado, vai se sentir impotente até. E trabalha com essa impotência, com essa sensação de incapacidade mesmo [...] É impotência quando a gente está no desconhecido. Quer dizer, é uma questão que eu não estou preparado. E o problema está lá, não dá para fugir [...] É aquela frustração, é a depressão, que falam do professor. O professor não vê o resultado eficiente naquele trabalho. Se não é um planejamento, se não é uma 
formação, se não há uma organização para você receber, por exemplo, a inclusão, então é a gente brincar. Ficar fazendo faz-de-conta que ensina, um faz-de-conta que aprende. Mas que fica uma frustração enorme aí. Fica uma coisa inexplicável. Isso que vai minando, vai desestimulando cada vez o professor em sala de aula.

Já Maristela, comenta a perda de entusiasmo de seus colegas pelo trabalho pedagógico:

Na verdade aquilo que me move a estar na escola e abraçar isso como paixão, como profissão, eu não encontro correspondência dentro da própria escola. Porque parece que dá uma invertida nas relações interpessoais aqui. Eu percebo que a questão pedagógica é o que menos move, o que menos anima meus colegas e parceiros, entende? Então pra mim o fardo está justamente aí. Minha prioridade, o que permearia o meu entusiasmo em relação a fazer parcerias, a conviver com essas pessoas e não é isso o que acontece, entende?

A solidão de Wanda também aparece diante de uma experiência nova. Ao mudar para o período noturno e dar aulas para jovens e adultos, a depoente vê-se sozinha e com medo:

Ah, eu cheguei aqui [no período noturno] morrendo de medo. Quando eu entrei na sala - que essas luzes aqui não iluminam muito, fica tudo muito amarelo - que eu subi no corredor, aquele monte de gente adulta, nas portas, no corredor, e eu andando, pra ir pra minha sala. Eu não sabia que era a minha sala. E aí eu fui lá - era lá no fundo - eu fui, subi essa escada, fui andando, já estranhei barbaridade. Aqueles adultos, aquelas pessoas mais de idade. Agora tem muita criança, de quinze, dezesseis anos. Não tinha. Agora tem. Então quando eu cheguei na classe que eu entrei, aquele medo... O medo que eu senti do escuro, de eu olhar pra janela e não ver a praça. Sabe essa escuridão que você está vendo agora? Mas, quando batia o sinal, que todos os professores entravam na sua sala, e era aquele silêncio, você trabalhava, calmamente, do jeito que você queria. Nunca ninguém chegou na porta para se intrometer, para falar alguma coisa. Você fica mais independente. Você fica, parece que mais dona daquela sala. E eles começam a gostar de você rápido, e é uma troca muito boa. Mesmo de experiência 
de vida. Que eles contam os problemas deles. E você acaba contando suas coisas também para eles. Eles ficam teus amigos, eles te abraçam. É tão gostoso, muito bom. Mas no começo, nessa primeira sala que eu peguei, eu sofri de medo. Mas passou rápido, muito rápido [...] Eu tive aquele medo, assim, no primeiro dia. Já depois tinha um aluno que me enfrentava muito. Horrível, com aquela aparência de jornal, de foto de jornal. E sentado bem aqui assim. E eu aqui. Uma letra horrorosa. Mas fazia tudo rápido. E ele fazia tudo rápido e ele levantava e ia ficar na porta. E eu não sabia nem como falar com ele, porque eu tinha até medo dele.

Quando trata de seus sentimentos, Wanda enfatiza que os professores não possuem apenas problemas referentes ao seu trabalho:

Porque você também tem seus problemas. Então você também não está vinte e quatro horas ligado na escola. Você também tem problemas em casa, de dinheiro, de outras coisas. Então você também é uma pessoa que necessita. De uma ajuda, de uma palavra, de alguma coisa [...] A gente traz muita coisa da nossa vida. Você também é um ser humano, como o seu aluno. Ele tem problemas? Você também tem.

A tristeza se prolonga para fora da escola:

Ah! Sabe? É muito difícil, você assistir um Jornal Nacional, ou um outro qualquer aí, quando dá, né? - porque eu trabalho à noite, não assisto quase nunca, só de sábado você não escuta nada que te alegre, nada, nada! Não tem alegria que vem de fora, nunca. Você passa momentos alegres, momentos. Na sua casa assim, rápidos, na rua rápidos, mas tudo muito rápido, os tristes são mais comuns, são mais fáceis de serem encontrados... [Wanda].

Sandra fala da frustração por não conseguir ensinar. Como se o ensino dependesse apenas de sua vontade ou de seus esforços:

Então, o professor tem que estar sempre intervindo com esse grupo de alunos [que não aprende], sempre intervindo, o tempo todo. E acaba não dando essas quatro horas pra trabalhar com eles. Então, o que sobra pra mim? Eu pessoalmente? Eu fico frustrada. 
Eu chego em casa, eu começo a pensar num grupo, eu começo a pensar no outro, às vezes eu começo a pensar num aluno individualmente. Hoje, por exemplo, eu percebi que tem alunos do grupo melhor que lê com muita dificuldade, mas que pra mim era um ótimo aluno. Faz a lição, é caprichoso. Mas, você percebe que agora na leitura ele tem uma leitura bem lenta. Não tem uma leitura fluente. Então, isso eu vou pensar em casa, começo a ter idéias, vou trabalhar isso, vou trabalhar aquilo, aí durmo de novo. Aí no dia seguinte, às vezes não dá pra preparar tudo aquilo, porque a vida da gente também não é só a escola, tenho filho, tenho marido, tenho casa pra arrumar, eu tenho comida pra fazer, eu tenho filhos pra mandar pra escola. Então, minha vida não é só escola. Se fosse, seria outra situação [...] Então é assim que eu me sinto. Me sinto meio frustrada. Já chegou o meio do ano, não consegui trabalhar quase nada de Matemática, por exemplo, sabe?

O sofrimento é tão intenso e o trabalho é tão solitário que as expectativas de aprendizagem para os alunos são cada vez menores:

Este ano eu estou tão apagada, tão apagada, não sei se eu estou ficando velha, cansada, ou se é esse tipo de sala. Eu não gosto desse tipo de sala toda misturada. O ano passado que tinha a sala projeto [antiga classe especial], com o D., com o B., com mil problemas de aprendizagem sérias mesmo, como eu tenho esse ano, mas eu me sentia mais comprometida com a classe. Acho que a palavra certa é essa. Esse ano eu não me sinto tão comprometida como eu me sentia o ano passado. Talvez porque eu insisti em formar a sala projeto, eu me propus a ficar com eles, e a minha expectativa de aprendizagem era muito maior do que esse ano. Eu não tenho ânimo de ensinar esses alunos que estão tão fora da segunda-série. Eu não tenho vontade de dividir a sala em grupos diferentes, eu não consigo trabalhar a mesma atividade com todo mundo. Então essa letra [bastão] eu ponho na lousa por causa daqueles que não copiam. Mas eles também não copiam. Também, mesmo que copiasse. O que isso vai influenciar ou ajudar, se eles não sabem ler? Se eles não sabem escrever? Eles só estão copiando. Porque aí eu estava colocando essa letra pra minha consciência ficar mais tranqüila. Pra falar: "Ah, estou preocupada com eles". Não estou. Porque tudo isso que está na lousa, só os bons alunos é que sabem o que está escrito - apesar de que a gente lê, e que a gente comenta - mas eu acho que o que eles absorvem é tão pouco do dia-a-dia [...]

Então eu estou sentindo que cada vez mais eu estou perdendo o controle da situação. 
Ou eu já grito logo de uma vez, já dou uns berros, ou então eu vou deixando, sabe? [...] Já falei até com o pai do L. - que já veio me procurar - eu não vejo que ele vai melhorar muito esse ano. Eu falei: "Se eu conseguir fazer o L. conseguir copiar alguma coisa, não fazer xixi na calça, fazer cocô na calça, eu já estou tão satisfeita”. Mas só fica por aí. E aí aqueles outros lá que não têm essas dificuldades que o L. tem - que são alunos normais, escrevem copiam, pintam, tem caderno, tem tudo arrumadinho - eu também não consigo dar conta deles. Então eu fico extremamente dividida. E isso me chateia muito. Então toda a vez que eu entro nessa sala que começa o barulho externo, Educação Física, recreio, tudo que faz barulho, e mais essa diferença que eu sinto na sala, isso vai me desanimando, vai me deixando tão angustiada [Sandra].

Apesar de ser claro, para quem olha e escuta atentamente, o quanto os professores estão solitários e sofrendo, é como se seus sentimentos não existissem dentro da escola:

Dá a impressão que nós não vivemos estas angústias, como se fosse um ritual burocrático, entende? Que não tivesse todo um sentimento por trás dessas frustrações todas. Eu acho que a culpa é um pouco nossa também. Talvez de não expressarmos. Tem todo um sentimento, tem toda uma expectativa. Sentimento de frustração, sentimento de impotência. De você querer fazer parte e fazer diferença na vida de seus educandos e muitas vezes isso não acontece. Porque além das dificuldades estruturais você tem dificuldades pessoais também [Maristela].

O desgaste é tão grande, que a necessidade é de socorro:

E nesse sentido então que eu percebo entre nós, como o professor sofre um desgaste muito grande. Talvez, inclusive, passa por aí a falta de subsídio, um trabalho mais integrado com coordenação pedagógica, que assista melhor o professor. Que dê um suporte para ele, que ele não se sinta sozinho nos trabalhos em sala de aula. Não deveria se sentir, ele se sente. E eu acho que isso cria esse desgaste. Porque você não tem onde se socorrer, é o que me parece [...] Eu acho que o professor está precisando de um suporte. Ele está se sentido isolado. E isso está desgastando o professor, no 
trabalho dele. Então eu sinto que ele se sente, não sei, mais desestimulado [Antônio Carlos].

*

A escola pública atual é o cenário no qual se constituem as relações entre a psicologia e a pedagogia. Sem condições de ensino e de aprendizagem, a instituição escolar, por meio dos professores, busca encontrar metodologias de ensino que garantam o aprendizado. Neste sentido, a psicologia é vista como a possibilidade de garantir a eficiência pedagógica. $\mathrm{O}$ processo de pseudoformação ${ }^{50}$ docente gera essa expectativa.

\footnotetext{
${ }^{50}$ Este conceito será melhor analisado no capítulo VIII, nas páginas 190 a 195.
} 


\section{CAPÍTULO VIII - A FORMAÇÃO DOS FORMADORES: predomínio da razão instrumental nos processos de pseudoformação}

Com a finalidade de investigar o lugar que o professor atribui à psicologia em sua formação e em seu trabalho pedagógico, compreendendo a apropriação e a avaliação feitas por ele da psicologia que lhe foi ensinada e as expectativas que possui para esta área do conhecimento, sete professores de uma escola municipal da cidade de São Paulo foram entrevistados. A leitura do conteúdo destes depoimentos permitiu estabelecer quatro categorias de análise: a) a relação que estabelecem com a psicologia, por meio de definições desta ciência, da presença dela no trabalho docente, de demandas para a psicologia e para os psicólogos e do contato que os depoentes tiveram com os profissionais dessa área; b) como a psicologia está presente nos cursos de formação; c) a maneira como os depoentes estabelecem a relação entre teoria e prática no processo formativo, priorizando a segunda como instrumento da primeira e, por fim, d) a situação da escola pública atual, que se configura como o cenário no qual se desenvolvem as relações entre a psicologia e a pedagogia. Vale ressaltar que a relação entre teoria e prática tornou-se o eixo de discussão sobre a formação docente em psicologia, como se verá, uma vez que perpassa todas as outras categorias.

No que se refere à relação estabelecida com a psicologia, os depoentes apresentam definições que ora se aproximam do objeto de estudo da psicologia, ora a definem por meio de sua função ou aplicabilidade. Em geral, a conceituação é do senso comum e trata de uma psicologia de auto-ajuda.

No trabalho pedagógico, a psicologia é evocada para embasar as ações do professor principalmente nos casos do que entendem como dificuldades de aprendizagem. Ela traz o suposto controle da relação professor-aluno, do processo ensino-aprendizagem e da disciplina, com a possibilidade imaginária de realizar um trabalho individualizado. Nesta medida, os professores consideram-se também psicólogos por exercer funções por eles atribuídas a esses profissionais. A psicologia explica os problemas da escola, por meio de uma linha de pensamento diagnóstica e 
fornece ao docente conhecimento que traz domínio das situações que se põem em seu cotidiano de trabalho, dando-lhe “jogo de cintura”. O mais relevante, para o professor, é a dimensão psicológica da relação com o aluno.

Quando fazem demandas à psicologia e aos psicólogos, pedem socorro, em virtude da vivência de desamparo, solidão e sobrecarga, que só pode ser compreendida se remetida à realidade escolar atual. A psicologia é tomada como instrumento de explicação do que acontece na escola, em geral, e no trabalho pedagógico, em particular, mas, não tem resolvido estas questões. Mesmo tendo certa clareza disso, os depoentes desejam a psicologia e, mais precisamente, o psicólogo como parceiro: sofrem porque não conseguem atender individualmente cada aluno e esperam que a psicologia atenda, sem questionar a relação professor-aluno individualizada.

A novidade no que diz respeito às demandas é a presença da psicologia na escola para trabalhar o sofrimento do professor, já que o desejo de ser preceptor ${ }^{51}$ traz necessariamente frustrações. Assim, além de solicitar, em alguns momentos, o encaminhamento dos alunos que não aprendem, querem, na maioria das vezes, a psicologia para aliviar angústias e, por isso, desejam o psicólogo na escola e não na formação. A experiência com eles, todavia, tem sido frustrante, porque consideram que a psicologia está distante da realidade escolar vivenciada.

A formação em psicologia é relatada como um amontoado de autores e teorias que se repetem de forma superficial e imprecisa. Pouco se lembram do que estudaram não só em psicologia, mas nos cursos em geral.

Os depoentes denunciam e criticam os estágios realizados, que apenas cumprem exigências burocráticas, sem preocupação com a preparação docente. Assim, o relato sobre o que e como estudaram demonstra o descaso absoluto com a formação do professor, como veremos.

A principal queixa sobre a formação diz respeito à falta de vínculo entre os conteúdos aprendidos e a prática pedagógica, ou seja, a falta de aplicabilidade, que denominam “ausência de aprofundamento”. Consideram que a boa formação é a que está voltada para a prática escolar; em conseqüência, formação ruim é formação "muito

\footnotetext{
${ }^{51}$ Alguém que atenderia individualmente cada aluno, como um professor particular. Essa questão será analisada mais detalhadamente nas páginas 170 a 174, com as contribuições de Azanha (1995 abc, 1998, 2000).
} 
teórica”. Não percebem, todavia, que não aprenderam teorias. No entanto, ao queixaremse da falta de vínculo entre o que estudaram e a realidade na qual trabalham demonstram que possuem alguma lucidez sobre a precariedade dos cursos de formação, dos quais saem sem se sentirem habilitados para exercer o magistério.

A relação entre teoria e prática permeia toda a fala dos entrevistados quando avaliam sua própria formação. Desejam a prática, sinônimo de ter efeito, ser útil, ter aplicabilidade, ajudar a resolver problemas, ter função, ser concreto, aprender fazendo, ter contato com o psicólogo na escola e não na formação. A vontade de aprender com estudos de caso e, por isso, aproximar-se da prática, reforça a visão preceptorial, do atendimento individualizado de cada aluno. Não percebem que a questão não é a falta de estudos de casos, mas a expectativa de ser um preceptor. As queixas sobre a escola e as condições de trabalho não chegam aos órgãos superiores, porque na realidade, acreditam que os problemas se resolveriam se ministrassem aulas para poucos alunos com a possibilidade de atender as necessidades de cada um.

A denúncia sobre as condições escolares fala da descaracterização da instituição escolar e do professor. Este tema não foi o foco dessa pesquisa, mas foi o mais abordado pelos depoentes: eles trataram principalmente da dificuldade de exercer sua profissão. Tudo falta na escola: ensino, aprendizagem, motivação, valorização, recursos materiais e humanos, respeito, comunicação, colaboração. O exemplo mais citado de dificuldade foi a inclusão de alunos com necessidades educacionais especiais. O acúmulo de funções do professor se agrava com as novas políticas de inclusão, uma vez que ele não está preparado para realizá-la.

Com o descaso atual pela sua profissão e com a própria perda de função da escola pública, os depoentes sentem-se, acima de tudo, sozinhos. Têm os mesmos problemas, mas não se comunicam. Talvez, por isso, tenham falado tanto sobre suas dificuldades quando me dispus a ouvi-los. Na relação com o pesquisador, estavam à procura de ajuda.

Esse é o cenário apresentado pelos professores entrevistados. Essa é a sua formação, realizada em faculdades desconhecidas ou em centros renomados, dentro da academia ou das próprias escolas em que trabalham. 
O que dizer sobre a formação do formador? Sobre o desejo intenso de aprendizado prático? Sobre a necessidade da aplicabilidade dos conteúdos? O que há de equivocado nos cursos que formam para o exercício do magistério? Em que realidade se inserem os cursos de formação e qual a sua finalidade? Como a psicologia se configura na preparação para a docência?

Ao tentar discutir essas questões, é preciso, primeiramente, compreender o cenário no qual os professores, as escolas e os cursos de formação estão inseridos.

\subsection{A política neoliberal para a educação}

A realidade da escola pública, apesar de não ter sido o eixo de nossa investigação, foi a questão mais tratada pelos depoentes durante as entrevistas. Falaram longamente sobre as condições de trabalho - o acúmulo de funções, a descaracterização do professor e da escola, a sobrecarga de atividades; a inclusão; seus sentimentos solidão, impotência, frustração, desamparo... Falam, desta forma, sobre as dificuldades de ser professor e de ensinar.

O caos vivido no cotidiano escolar não pode ser compreendido como específico da escola onde os depoentes trabalham. Suas queixas e denúncias não se circunscrevem a uma determinada unidade de ensino. O desmanche da escola pública está em questão: ocorre de modo intencional, muitas vezes planejado, com finalidades específicas. Para compreender o que vem ocorrendo com a educação pública é preciso analisar as políticas liberais e sua reapropriação no neoliberalismo, que se fundamentam, dentre outras questões, em dois aspectos básicos: na exploração sem limites e na exaltação da responsabilidade individual.

Vale ressaltar que a ideologia liberal era ao mesmo tempo falsa e verdadeira, permitindo, ainda, a existência de brechas, que possibilitavam a expressão e compreensão da contradição. Nela a educação, por exemplo, não era para todos, mas apregoava-se que poderia vir a ser. Por isso, vigorava a idéia de aperfeiçoamento da 
sociedade. Já a ideologia neoliberal é mentira manifesta. Apresenta as relações sociais existentes como as únicas possibilidades, por isso, aos indivíduos cabe a adaptação, uma vez que não há perspectivas de mudanças. O neoliberalismo apresenta como novo o que é muito antigo, com uma outra roupagem e, neste sentido, exclui a novidade.

Maia (2002) aponta a função da ideologia no liberalismo que serve para justificar a injustiça e a exploração do modo de produção capitalista. Ela pretende coincidir com a realidade. No neoliberalismo, a ideologia vem para afirmar o existente: algo é e não pode ser de outro modo.

No neoliberalismo, de acordo com Suárez (2004), ocorre a substituição da cidadania, do bem comum, da democracia, da educação pública pela ética do mercado de livre consumo; o discurso educacional, assim, vai se tornando cada vez mais econômico e menos político. Para produzir e reproduzir o capital é necessário criar e manter níveis de exploração nunca vistos antes. Trata-se de uma exploração visível no âmbito econômico, mas que atinge os aspectos políticos, sociais, culturais e simbólicos da sociedade.

A invasão neoliberal, segundo Bourdieu $(1998,2001)$, tem aumentado ainda mais a desigualdade entre ricos e pobres, necessitando cada vez menos dos trabalhadores para produzir riquezas, das quais nunca serão proprietários. Há, principalmente nos países mais pobres, um exército de reserva de mão-de-obra docilizada pela precarização do trabalho ou pela falta dele, disponível a qualquer preço, a qualquer momento para se submeterem obedientemente à exploração dos donos do capital. Milhares de pessoas morrem de fome, enquanto poucos empresários não sabem o que fazer com tanto dinheiro. Criam-se, de acordo com o autor, cada vez mais prisões, aumenta-se o número de policiais nas ruas, ao invés de creches, escolas e hospitais. Estão dadas as condições de degradação humana e de manutenção da opressão do povo, que sobrevive não se sabe como, submisso, acreditando que sua miséria é de sua responsabilidade.

O discurso neoliberal apresenta-se como unanimidade, inevitabilidade e fatalidade necessárias para constituir o que há de essencial na força simbólica do discurso dominante. Bourdieu (1998, p. 11) destaca que “[...] os tempos são duros e a margem de manobra não é grande”. 
No contexto neoliberal evidenciam-se o desprezo e a depreciação da coisa pública, instituindo-se o discurso público de elogio à empresa privada. Para Gentili (2004), o neoliberalismo descarta a necessidade da existência dos direitos sociais e políticos, alegando que eles geram um clima social de acomodação e desrespeito pelo esforço e mérito individual. Neste sentido, como enfatiza Bourdieu (1998), a política neoliberal promove o reinado absoluto do mercado e do consumidor, que passou a ser o substituto do cidadão.

Os direitos sociais - saúde, habitação, lazer, cultura, educação, trabalho... tornaram-se mercadorias e, portanto, seguem as leis do comércio. Frigotto (2004) discute a regulação da educação pelo mercado e, neste sentido, não cabe tratar da educação para a cidadania. Tornando-se uma mercadoria ou um serviço, é passível de ser comprada. Aqueles que possuem dinheiro podem comprar educação de qualidade, já a maioria da população marginalizada... Bourdieu (2001, p. 31) afirma que “[...] o Estado desertou de qualquer função econômica, vendendo as empresas que possuía, convertendo bens públicos como a saúde, a habitação, a segurança, a educação e a cultura - livros, filmes, televisão e rádio - em bens comerciais e os usuários em clientes" (grifo do autor).

A política do Estado mínimo faz com que o Estado se retire do que antes era sua incumbência. No que diz respeito à educação, segundo a perspectiva neoliberal, a escola está em crise porque é pública e o Estado não dá conta de administrá-la. Os sistemas escolares deveriam, assim, se tornar mercados escolares, fundamentando-se no mérito e no esforço pessoal, permitindo a competitividade (GENTILI, 2002).

São vários os setores cujo investimento público se torna cada vez menor. Como dito anteriormente, cultura, lazer, educação, trabalho, habitação, saúde, não são mais responsabilidades do Estado, o que os descaracteriza como direitos do cidadão. É preciso, assim, não perder de vista que as políticas públicas para tornar a educação um serviço financiado e fornecido pela iniciativa privada fazem parte de um contexto bem amplo das políticas neoliberais que pretendem organizar toda a vida em sociedade.

No que diz respeito à educação, especificamente, a coletânea de artigos “Pedagogia da exclusão - crítica ao neoliberalismo em educação”, organizada por 
Gentili (2004), identifica a ofensiva neoliberal como uma “pedagogia da exclusão”. Connell (2004, p. 11) considera que:

A maneira como a escola trata a pobreza constitui uma avaliação importante do êxito de um sistema educacional. Crianças vindas de famílias pobres são, em geral, as que têm menos êxito, se avaliadas através dos procedimentos convencionais de medida e as mais difíceis de serem ensinadas através dos métodos tradicionais. Elas são as que têm menos poder na escola, são as menos capazes de fazer valer suas reivindicações ou de insistir para que suas necessidades sejam satisfeitas, mas são, por outro lado, as que mais dependem da escola para obter sua educação.

Se a escola pública é responsável por atender crianças, jovens e adultos pobres, que constituem a maioria da população nos países subdesenvolvidos, verifica-se, então, a imposição de uma violência legítima de quem detém o monopólio econômico e simbólico sobre tais pessoas, na medida em que, por meio da escola, os alunos não adquirem os bens culturais necessários para que obtenham poder e possam criar forças de resistência contra as forças de opressão neoliberais. Para Gentili (2004), a educação das maiorias, na política neoliberal, é educação para o desemprego e para a marginalidade.

Costa (2004) discute que, com a transformação da educação pública em mercadoria, o ensino passa a ser regulado pela economia, financiado por órgãos internacionais, como o Banco Mundial, com o aval e com as prescrições do Fundo Monetário Internacional. As medidas para a educação têm como justificativa fatores essencialmente econômicos. As máquinas estatais que deveriam gerir políticas de educação esvaziaram-se; por isso são muito bem vindas as propostas de financiamento privado, já que o Estado é tido como ineficiente ao administrar este setor. Bourdieu (2001) avalia que, de direito fundamental, a educação transformou-se em fonte de lucro.

Como aponta Fonseca (2004), a partir da década de 1960 o Banco Mundial passa a financiar a educação nos países da América Latina, com o objetivo de desenvolvimento econômico, criando padrões de eficiência nos sistemas de ensino e na gestão dos recursos financeiros, a fim de formar mão-de-obra qualificada para desenvolver economicamente os países. As regras do Banco Mundial para o financiamento da educação são as mesmas de qualquer outro projeto comercial, ou seja, 
por ser um banco visa exclusivamente ao lucro. Especialistas financeiros estrangeiros determinam finalidades para a política educacional e criam formas de avaliar a eficiência de programas de ensino de acordo com critérios essencialmente econômicos e mais lucrativos.

Torres (2004) ressalta que o Banco Mundial é composto por economistas e não por educadores. A finalidade dos financiamentos - investimentos - é a eficiência econômica, a liberdade de mercados e a globalização do capital. Os valores culturais e democráticos que fundamentavam a educação tornam-se secundários ou até mesmo inexistentes.

Assim, ao analisar as queixas, críticas e denúncias dos depoentes sobre a realidade escolar em que vivem, é preciso situá-las no contexto dessas políticas para a educação, no qual se evidenciam propostas economicistas de mercantilização do que antes era direito dos cidadãos. O barateamento da escola, com a conseqüente falta de professores, baixos salários, acúmulo de funções, péssimas condições de trabalho (excesso de alunos em sala de aula, jornada dupla ou tripla de trabalho, falta de recursos materiais) e formação precária fazem parte de uma lógica perversa da educação para as massas, na qual o raciocínio é econômico e não político-social.

Os financiadores e propositores das mudanças curriculares, da implementação de propostas pedagógicas abstratas, descontextualizadas das escolas e muitas vezes dos países em que são desenvolvidas, provêm da iniciativa privada e de grandes agentes financeiros, como o Banco Mundial, que determinam o que será realizado em cada projeto. Os estrategistas de modelos educacionais estão muito distantes da escola: são economistas, administradores, investidores. Professores, diretores e coordenadores pedagógicos, nem sequer são consultados sobre o que serão obrigados a executar. Faltalhes, portanto, poder. Quem constitui e dá vida à escola é destituído de poder nas decisões que os afetam:

As chamadas "escolas eficazes" e os movimentos nacionais de testes dão continuidade à conviç̧ão de que a pesquisa quantitativa gerará uma política pública de forma mais ou menos automática. Os/as professores/as são definidos/as, nessa perspectiva, como receptadores/as passivos da ciência educacional e não como produtores/as, eles/as próprios/as de conhecimento fundamental (CONNELL, 2004, p. 20). 
Assim, as discussões sobre as políticas educacionais não envolvem os usuários da escola, tampouco os professores e equipe técnica. Sofrem uma violência constante no espaço em que deveriam aprender a ser capazes de resistir. Lidar com instituições poderosas, como a escola, segundo o autor, requer poder. Famílias e professores não possuem poder. Connell (2004, p. 20) também avalia que “[...] dos/as professores/as espera-se que implementem as políticas públicas, não que as formulem. As pessoas pobres são definidas como os objetos dessas políticas, não como autoras da transformação social”.

Voltando aos depoentes e às suas denúncias: falam da escola que está deixando de ser pública, indignam-se com a desvalorização de sua profissão, revoltam-se com índices alarmantes de analfabetismo daqueles que estão na escola, queixam-se do acúmulo de funções, mas não sabem por que tudo isso ocorre.

Os docentes não participam das decisões sobre as políticas educacionais, como a progressão continuada, por exemplo; seguem propostas pedagógicas mesmo que as considerem equivocadas; denunciam absurdos como a inexistência da recuperação paralela prevista em lei, a falta de professores substitutos na ocasião de licença dos efetivos, a execução de tarefas não-docentes, o que constitui a desvalorização de sua profissão, mas ao final de tanta lucidez sobre os males enfrentados pela escola pública, caem na velha fórmula liberal, localizando a causa de suas dificuldades para ensinar no indivíduo: sucesso ou fracasso escolar e social tem causas individuais.

Bourdieu (1998) afirma que, no neoliberalismo, há sempre uma justificação teórica para o fato de alguns serem privilegiados e obterem sucesso. Os adversários (dominantes) se armam com teorias para explicar a falta de competência da maioria da população marginalizada:

A ideologia anglo-saxã, sempre um pouco moralizante, distinguia os pobres imorais e os deserving poor - os pobres merecedores - dignos da caridade. A essa justificação ética veio acrescentar-se, ou substituíla, uma justificação intelectual. Os pobres não apenas são imorais, alcoólatras, corrompidos; são estúpidos, pouco inteligentes. Para o sofrimento social, contribui em grande medida a miséria do desempenho escolar que não determina apenas os destinos sociais, mas também a imagem que as pessoas fazem desse destino (o que 
contribui sem dúvida para explicar o que se chama de passividade dos dominados, dificuldade de mobilizá-los, etc.) (Id. Ibid., p. 60, grifo do autor).

No caso da escola, pobres e culpados por sua posição de marginalidade são alunos e professores. Os primeiros vindos das classes mais desprovidas econômica, cultural, social e politicamente. Os segundos, que tentam distinguir-se dos primeiros, são, na maioria das vezes, pertencentes à mesma classe social, acreditando que, por meio de jornadas esgotantes de trabalho e de sua formação, irão ascender socialmente. Bourdieu (1998) considera que os dominados - professores e alunos - precisam enfrentar os dominantes também com armas intelectuais e culturais que não os responsabilizem individualmente por aquilo que é de responsabilidade de medidas políticas que promovem a marginalidade e a miséria.

As idéias liberais, todavia, impedem que os dominados armem-se intelectualmente, uma vez que acusam a vítima - usuários da escola pública e também educadores - e pregam a auto-ajuda - o esforço individual proporciona a superação de limites como a miséria. Bourdieu (1998) destaca, ainda, que a precariedade das condições de vida torna possíveis novas estratégias de dominação e exploração, impedindo a mobilização e a reivindicação. Voltemos à fala de Carla, destacada no capítulo anterior:

Eu já trabalhei de várias coisas na minha vida. Nada ilícito, mas eu já trabalhei de várias coisas: já fui recepcionista de pet shop, eu já administrei uma empresa, eu já fui secretária junior, eu já fui professora de inglês, já fui professora de culinária, já trabalhei em cozinha de restaurante. Então quando você não curte um trabalho, você acha que o salário não está bom, você acha que os benefícios não estão bons, você sai na rua e você procura uma coisa melhor pra você, alguma coisa que melhor te encaixa. E quando você acha essa coisa que melhor te encaixa, você abandona aquela que não te agrada. Eu saí de um salário de $R \$ 300,00$ pra ganhar $R \$$ 800,00 agora. Esse salário me agrada. Só que quem saiu de greve ganha $R \$ 2.500,00, R \$ 3.000,00$. Então, pra elas se você tirar $R \$ 50,00$ a $R \$ 80,00$, que é o valor da falta na greve, não faz a menor diferença. Ela não vai simplesmente na manicure, na cabeleireira a semana que vem, ela vai na outra semana, acabou. Agora pra quem ganha $R \$ 800,00$, você tirar 
praticamente $10 \%$ do seu salário pra faltar um dia, é um negócio assim que... E você brigar por uma coisa que você está achando que é bom? Você concorda que não tem função? Tudo o que está na prefeitura hoje em dia me agrada: eu gosto de trabalhar aqui, eu gosto do sistema de trabalho, eu gosto da maneira com a qual eu recebo, eu gosto dos benefícios que eu tenho aqui e eu não vou conseguir sair daqui, por exemplo, e pegar um trabalho de meio período ganhando $R \$ 800,00$ ! Isso é surreal em nível de Brasil! Eu acho que, se alguma coisa me desagradar, eu não tenho que fazer greve, fazer piquete, sabe? Estou dando mau exemplo pros meus alunos, sendo anarquista. Nada de política, mas eu não acho que eu estou dando um bom exemplo. Se você parar pra olhar na televisão, por exemplo, esses dias teve um bando de professor aí, no outro estado, que tentou quebrar o Palácio do Governo. Foi todo mundo preso, teve desacato à autoridade. Espera aí, sou educadora! Eu não posso achar que é bonito desacato à autoridade. Se eu fizer isso, e eu aparecer na televisão, meu aluno no dia seguinte não vai me respeitar. Ele não vai respeitar a minha autoridade. Se eu desacato a autoridade é porque isso não vale a pena. Então, as pessoas não acham isso. As pessoas - essas que me viraram a cara - acham que eu furei a greve porque eu vim trabalhar. Eu acho que elas são obrigadas a me aceitar, do jeito que eu sou, assim como eu as aceito do jeito que elas são. E eu acho que se isso não vai ser agora, um dia isso será.

Na fala da depoente identifica-se a presença de inúmeras proposições liberais, principalmente no que se refere ao esforço e mérito individuais. Ser ou não ser bem sucedido profissionalmente e ganhar um bom salário fazem parte, na avaliação da professora, da vontade e do esforço próprio. Chama a atenção, ainda, a satisfação com um salário que mal paga as suas contas, como apontado por ela no momento inicial de nossas entrevistas. Receber, porém, R\$ 800,00 por mês lhe agrada profundamente. Carla, quando fala de seus ganhos financeiros, desconsidera que é uma professora, investiu anos de sua vida em formação para o magistério, pagando uma faculdade particular - porque poucos são os que têm acesso a uma Universidade pública - e especialmente que esse é um salário aviltante, porque a violenta em suas necessidades básicas. Bourdieu (1998) lembra que o salário recebido por uma pessoa é um sinal inequívoco do valor atribuído ao trabalho e ao trabalhador: “[...] o desprezo por uma função se traduz primeiro na remuneração mais ou menos irrisória que lhe é atribuída” 
(p. 11). Bosi (1996) complementa que o salário do professor é o retrato fiel da importância dada à qualidade do ensino no Brasil:

[...] o nosso professor primário é remunerado como se fosse um operário não qualificado. O seu salário nada tem a ver com a importância crucial da sua função pública, que é a de primeiro motor do desenvolvimento, nem merece as ácidas cobranças de eficiência que periodicamente lhe fazem a mesma sociedade e o mesmo estado, que o deixaram à míngua (p. 14).

Bourdieu (1998) afirma que quem trabalha com questões sociais, em tempos de neoliberalismo, como professores, tem a impressão constante de ser iludido ou desautorizado. Mais grave ainda é o caso da depoente que se sente detentora de autoridade por ser uma professora, sem se dar conta de que sua profissão é profundamente desvalorizada e desautorizada, inclusive pelo salário que recebe.

Ao analisar a precariedade de vida dos desempregados e daqueles que sobrevivem graças a empregos temporários ainda mais exploradores, Bourdieu (1998, p. 120) destaca seus efeitos:

[...] a desestruturação da existência, privada, entre outras coisas, de suas estruturas temporais, e a degradação de toda relação com o mundo e, como conseqüência, com o tempo e o espaço. A precariedade afeta profundamente qualquer homem ou mulher exposto a seus efeitos; tornando o futuro incerto, ela impede qualquer antecipação racional e, especialmente, esse mínimo de crença e de esperança no futuro que é preciso ter para se revoltar, sobretudo coletivamente, contra o presente, mesmo o mais intolerável.

No depoimento de Carla nota-se que as contradições do mundo social são vividas como dramas pessoais. A individualização das relações sociais é uma estratégia liberal para manter a submissão e a obediência, uma vez que isola, atomiza, desmobiliza e rompe com a solidariedade (BOURDIEU, 1998). Para Gentili (2002, p. 22), “[...] o neoliberalismo privatiza tudo, inclusive o êxito e o fracasso social”.

As condições de vida e de trabalho dos professores são extremamente precárias, igualando-se, muitas vezes, a de seus alunos e suas famílias. Desta forma, a depoente considera um ganho significativo, e até mesmo a possibilidade de ascender socialmente, o "aumento" de seu salário que se tornou quase três vezes maior do que o recebido 
anteriormente. Por esta perspectiva, considera-se privilegiada, acreditando que, por esforço próprio, adquiriu uma posição de maior poder na escala social, da qual sente-se orgulhosa e, além disso, avalia que sua profissão é valorizada. Com um salário medíocre, vivendo em péssimas condições de trabalho, destituída de qualquer possibilidade de poder, sem autoridade perante alunos, comunidade e órgãos governamentais, a professora não percebe que a autoridade encontra-se muito longe de sua profissão. Situação semelhante ocorre com trabalhadores desempregados, conforme analisa Bourdieu (1998, p. 121):

[...] A existência de um importante exército de reserva, que não se acha mais apenas, devido à superprodução de diplomas, nos níveis mais baixos da competência e de qualificação técnica, contribui para dar a cada trabalhador a impressão de que ele não é insubstituível e que o seu trabalho, seu emprego, é de certa forma um privilégio, e um privilégio frágil e ameaçado (é aliás o que lembram a ele, ao primeiro deslize, seus empregadores, e, à primeira greve, os jornalistas e comentaristas de todo gênero). A insegurança objetiva funda uma insegurança subjetiva generalizada [...] Os desempregados e os trabalhadores destituídos de estabilidade não são passíveis de mobilização, pelo fato de terem sido atingidos em sua capacidade de se projetar no futuro.

Observa-se, dessa forma, a busca, por parte da depoente, de estabilidade, segurança e valorização quando se insere no contexto educacional e torna-se professora de uma escola pública municipal. A insegurança, no entanto, encontra-se em todos os lugares, desde a impossibilidade de revoltar-se e manifestar-se contra os baixos salários, até mesmo na própria descaracterização da profissão, como destacado em vários momentos das entrevistas, na qual os professores relatam as diversas atividades não docentes que desenvolvem.

O discurso neoliberal, portanto, torna-se dominante e legítimo, impondo ao povo como alternativa ou o liberalismo ou a barbárie, ocultando que o liberalismo é uma forma de barbárie que promove relações de desigualdade, opressão e miséria absoluta de milhões de pessoas. Para Bourdieu (2001), é difícil combater a visão neoliberal porque ela se apresenta como progressista, embora seja conservadora. Destruir conquistas sociais do passado (como o direito à greve) é tido como progresso, desenvolvimento e 
flexibilidade. Neste sentido, de acordo com Gentili (2004), o discurso neoliberal cria e produz uma realidade que torna impossível pensar em outra.

Vivendo, pois, num sistema de instabilidade crônica, professores estão desarmados e desarticulados para compreender e contestar a ordem das coisas. Isto se reflete na adesão a modelos pedagógicos impostos, mesmo que os critiquem, na consolidação de práticas educativas preconceituosas, mesmo que, em discurso, as combatam ou ainda no comprometimento com atividades não docentes, mesmo que se indignem.

Ao analisar as políticas neoliberais e seus impactos no campo educacional, Gentili (2002) conclui que elas trouxeram mudanças nas formas históricas de pensar as práticas pedagógicas e a escola pública. Em outro momento, (GENTILI, 2004), destaca que a acumulação do capital implica uma tendência generalizada e crescente à mercantilização de todas as coisas, não apenas nas coisas materiais, mas também na materialidade da consciência. Sobre os impactos na vida social, o autor enfatiza a privatização dos direitos básicos do cidadão. No que se refere à educação, afirma que o mercado de trabalho passa a orientar as decisões da política educacional:

Trata-se, enfim, de transferir a educação da esfera da política para $a$ esfera do mercado, negando sua condição de direito social e transformando-a em uma possibilidade de consumo individual, variável segundo o mérito e a capacidade dos consumidores. A educação deve ser pensada como um bem submetido às regras diferenciais da competição. Longe de ser um direito do qual gozam os indivíduos, dada sua condição de cidadãos, deve ser transparentemente estabelecida como uma oportunidade que se apresenta aos indivíduos empreendedores, aos consumidores "responsáveis", na esfera de um mercado flexível e dinâmico (o mercado escolar). A reforma administrativa proposta pelo neoliberalismo orienta-se a despublicizar a educação, a transferi-la para a esfera da competição privada. Reduzida à sua condição de mercadoria, a educação só deve ser protegida não por supostos direitos "sociais", mas pelos direitos que asseguram o uso e a disposição da propriedade privada por parte de seus legítimos proprietários. É nesse marco que se reconceitua a noção de cidadania, mediante uma revalorização da ação do indivíduo enquanto proprietário que elege, opta, compete para ter acesso a (comprar) um conjunto de propriedades-mercadorias de diferentes tipos, sendo a educação uma delas. $\mathrm{O}$ modelo do homem neoliberal é o cidadão privatizado, responsável, dinâmico: o consumidor (GENTILI, 2002, p. 19-20, grifo do autor). 
O modelo mercadológico, empresarial reproduz-se, também, na esfera da formação docente. Já que a formação de qualidade não é um direito do educador, mas a possibilidade de tornar-se propriedade privada, desde que ele seja um consumidor responsável, atento e dedicado, cabe a cada professor buscar e comprometer-se individualmente com sua capacitação. Essa é, segundo Gentili (2002), outra forma de privatização da educação, que não se trata meramente do aspecto econômico, vinculado à diminuição do investimento governamental na área educacional. A privatização da formação refere-se à reprodução, no campo pedagógico, de modelos de formação nos moldes empresariais. Para o autor, a saída encontrada pelo neoliberalismo para a crise educacional “[...] é produto da combinação de uma dupla lógica centralizadora e descentralizadora: centralização do controle pedagógico (em nível curricular, de avaliação do sistema e de formação docente) e descentralização dos mecanismos de financiamento e gestão do sistema” (Id. Ibid., p. 25, grifo do autor).

Analisando os depoimentos apresentados, compreende-se, dessa forma, a presença tão intensa de sentimentos de desamparo, descaso, solidão, frustração, impotência e infelicidade. Os depoentes estão, de fato, sozinhos na atividade de ensinar, mas, ao mesmo tempo, são avaliados e fiscalizados constantemente quanto à sua competência e aos resultados de seu trabalho.

Tornando-se a educação um bem a ser adquirido, passando para a esfera privada, na qual incentiva-se a competição, também é preciso desarticular professores da idéia de bem público e de que sua profissão deve lutar por questões coletivas, promovendo o desenvolvimento intelectual e cultural de seus alunos, gerando inquietação e recusa quanto à produção da desigualdade.

Os sentimentos dos entrevistados são perfeitamente justificáveis quando o professor deixa de formar cidadãos para formar consumidores. Cada consumidor deve formar-se individualmente, de acordo com seu próprio mérito e competência. Cada professor será um bom profissional de acordo com seu esforço e sua vontade, sem o apoio de sua categoria, que se desmantelou, ou de quem organiza e deveria dar respaldo para a escola, inclusive estabelecendo políticas públicas de promoção da cidadania. 
É nesse contexto que os depoentes apresentam queixas, sofrimentos, críticas, denúncias, indignação e também conformismo. Numa escola pobre - alunos pobres, professores pobres, recursos humanos e materiais pobres - lutam constantemente pela sobrevivência de seu próprio trabalho, que cada vez mais perde valor, de suas idéias e também, por que não, da escola pública. A dificuldade em exercer o seu ofício, ou seja, ensinar, possui explicações que ou ficam na superfície, ou têm influência de preconceitos ou revelam alguma lucidez sobre a política educacional. Impregnados pelo discurso hegemônico, des-historicizado e por isso verificável empiricamente, têm uma expectativa cada vez menor de aprendizagem para os alunos da escola pública.

Vítimas da mesma política de opressão, alunos e professores tornam-se inimigos. Argumenta-se, no sistema hegemônico, que os mais competentes terão trabalho e posições de poder. Aos menos competentes, dão-se baixos salários, ou no caso dos docentes, a ilusão de que, com cursos de formação medíocres, se tornarão competentes e terão a possibilidade de ascender.

Vive-se o primado das coisas sobre as pessoas, conforme destaca Bosi (1996, p. 14): “As pessoas, quando respeitadas no seu ofício, produzem sentido e valor. Com ou sem as coisas. Mas as coisas sem as pessoas são letra morta. Preferir coisas a pessoas não é realismo. É apenas conformismo”.

Dentro da perspectiva neoliberal, desenvolvem-se cursos de formação docente, com objetivos economicistas, desvinculados da escola e, principalmente, da escola pública. Desvalorizados em sua função, professores não precisam ser formados. Basta que sejam pseudoformados e tenham a convicção de que estão prontos para exercer o magistério.

A pseudoformação inicia-se com o desejo por ser um preceptor, ou seja, um professor particular para alunos particulares, em classes com quarenta alunos. A psicologia surge, então, na preparação para o magistério, como a redentora dos problemas individuais.

Cumprindo sua função liberal, a psicologia científica insere-se na formação de professores para eximir a escola da produção das dificuldades de aprendizagem e de escolarização, atribuindo a causa destes problemas aos indivíduos. Em geral, explica a 
falta de aptidão dos alunos pobres e apresenta aos docentes supostas fórmulas de controle e manipulação do processo de desenvolvimento cognitivo.

Nos depoimentos, verifica-se que certa psicologia foi muito bem aprendida: a da responsabilização do indivíduo por suas dificuldades escolares e também sociais. Para ensiná-lo, é necessário uma pedagogia que se esqueceu da escola porque pressupõe o ensino individualizado, o atendimento preceptorial.

\subsection{Do coletivo ao individual - a psicologização da escola}

Quando tratam da formação tanto em psicologia, como da formação em geral, os depoimentos apresentam constantemente as dificuldades enfrentadas pelos professores para cumprir as metas educacionais. A causa das dificuldades é atribuída, principalmente, dentre outros fatores, à impossibilidade de realizar um ensino individualizado. Assim, os depoentes relatam o desejo de trabalhar com auxiliares de classe, para atender melhor aos alunos; manifestam a vontade de ter a presença do psicólogo na escola para ajudar aqueles que não aprendem; falam da importância da recuperação paralela em pequenos grupos.

As alternativas por eles encontradas para recuperar os "alunos atrasados”, com “dificuldades de aprendizagem” ou também com "problemas de disciplina” estão essencialmente localizadas no âmbito individual: a criança possui deficiências, problemas emocionais, neurológicos, cuja solução também é individual - ela precisaria de um professor particular.

Instaura-se na escola o mito de que o ensino e o atendimento individualizados solucionariam as dificuldades existentes. A questão esquecida é primordial: a escola pública pressupõe um espaço por excelência de ensino e aprendizagem coletivos. Ao compreender que os problemas teriam solução com propostas individuais de ensino e de atendimento ao aluno, rompe-se com o fundamento da escola para todos. Não se trata mais de ensinar como se educavam os príncipes e os docentes sabem da inviabilidade dessa proposta, mas a desejam. Compreendem que não seria possível - por razões práticas - a existência de um professor para cada aluno, mas vislumbram esta alternativa 
como solução para os males enfrentados. De onde vem o equívoco? Certamente a psicologia tem muito a contribuir para o desejo de propostas pedagógicas individualizadas dentro da educação escolar, que, por princípio, é coletiva.

Carvalho (2001) retoma, setenta anos depois, o que Lourenço Filho propunha na em 1929: a psicologia apresentada nos cursos de formação ainda tem o objetivo de conhecer as crianças para melhor ensiná-las e controlá-las. É isto que os professores depoentes aprenderam com a psicologia e que está na base de suas concepções de ensino e de sua insatisfação: uma promessa impossível de controle do processo de ensino e da relação professor-aluno.

Mantém-se nos cursos de formação, além disso, as explicações para as desigualdades sociais por meio das supostas desigualdades naturais, que surgiram no século XIX, como analisado por Bisseret (1979).

A psicologia, segundo Carvalho (2001), desde o início do século XX foi vista como a disciplina que traria conhecimentos científicos para a melhoria das ações pedagógicas. O autor discute, neste trabalho, a transferência e aplicação acríticas de conceitos e referenciais da psicologia do desenvolvimento para a educação, especialmente da epistemologia genética de Piaget.

Tendo como base os trabalhos de Piaget e de seus colaboradores, Carvalho mostra como o construtivismo psicologizante ignora o contexto e os problemas das instituições escolares, resultando numa pedagogia centrada na criança e em seu desenvolvimento. No cerne de sua reflexão encontra-se a distinção entre a criança e o aluno. Os estudos e pesquisas em psicologia do desenvolvimento da criança passam a explicar o aluno e produzem princípios pedagógicos de como educá-lo, ou seja, desconsideram que um aluno insere-se no contexto escolar de aprendizagem absolutamente distinto de outras formas de aprendizagem e desenvolvimento cognitivo, emocional e afetivo que fazem parte da vida de uma criança. Como argumenta o autor:

Assim, procede-se nesses discursos pedagógicos como se fosse possível compreender o aluno pela simples transposição ou adição de descrições de um sujeito psicológico ou epistêmico; enfim de referenciais que perdem a sua concretude se abstraídos das redes conceituais e dos interesses descritivos a partir dos quais foram elaborados (CARVALHO, 2001, p. 35). 
O problema, segundo o autor, não se situa na maneira desvirtuada com que as propostas originais de Piaget foram apropriadas e aplicadas na escola e que, portanto, bastaria o retorno com fidelidade à sua teoria. O equívoco, que pode ser estendido a outras teorias psicológicas do desenvolvimento, refere-se à transposição de pesquisas fora do contexto escolar sobre o desenvolvimento cognitivo individual de crianças para o contexto escolar, no qual alunos aprendem e são ensinados coletivamente.

Daí decorre o desejo intenso dos educadores por propostas individualizantes que supostamente resolveriam as questões da aprendizagem. Sua expectativa é a de que se possuírem conhecimentos sobre desenvolvimento infantil ou sobre como controlar o processo cognitivo e tiverem a oportunidade de trabalhar com indivíduos, de maneira isolada, ou com pequenos grupos, terão seus problemas solucionados. Por isso encontram tanta dificuldade em aplicar/transportar os conhecimentos aprendidos nos cursos de formação para a realidade escolar, considerando-os teóricos e abstratos.

Carvalho (2001) ressalta que o objetivo fundamental da teoria de Piaget e de alguns de seus seguidores é elaborar teorias explicativas do desenvolvimento cognitivo e não uma compreensão do contexto escolar ou aplicação imediata destas teorias neste âmbito. Tais investigações não têm como finalidade buscar formas mais eficazes de ensino $^{52}$. Pretendem descrever as características gerais do desenvolvimento cognitivo da criança a partir de certos referenciais psicológicos. Mas, não é a criança, como objeto de conhecimento da psicologia, que está na escola: é o aluno, dentro do contexto escolar, em relação com outros alunos e com professores, como elemento das finalidades de uma instituição educativa que se organiza a partir de inúmeros determinantes sociais, econômicos, políticos e culturais. Nesse sentido, as teorias da psicologia sobre desenvolvimento infantil não podem explicar o que acontece na escola.

Por isso, o autor avalia que a psicologia do desenvolvimento é insuficiente para estabelecer as bases científicas de uma proposta pedagógica. As pesquisas sobre desenvolvimento cognitivo não têm como ponto de partida, nem como seu destino, o contexto e a instituição escolar. Tratam do processo de conhecimento independente da aprendizagem escolar.

\footnotetext{
${ }^{52} \mathrm{O}$ autor destaca, contudo, que muitos escritos de Piaget e de seus colaboradores discutiram as contribuições do construtivismo para a escola, inclusive quanto à possibilidade de melhoria das ações pedagógicas.
} 
A partir disso, instala-se o equívoco presente nos cursos de formação: ensinam ou pretendem ensinar - teorias psicológicas como fundamento para ações pedagógicas com o fim de proporcionar melhorias no ensino, tornando-o mais eficaz. Todavia, conforme observado nos depoimentos, nem teorias psicológicas são ensinadas, muito menos ações educativas são modificadas pela razão simples de que, por mais que se esforcem, não há condições práticas e viáveis de se aplicar os modelos psicológicos de desenvolvimento individual em classes de quarenta alunos. Carvalho (2001, p. 35) questiona:

\footnotetext{
Em que medida, por exemplo, a simples compreensão desses aspectos gerais em uma perspectiva do indivíduo pode ser elucidativa do processo de aprendizagem dos conteúdos, das capacidades e dos valores específicos da escola, na qual a criança se situa em um contexto de ensino coletivo, e não de preceptorado individual? (grifo do autor).
}

Trata-se, portanto, de examinar a adequação da apropriação do discurso psicológico como base para compreender os problemas relativos a alunos e instituições escolares. É preciso, segundo o autor, considerar o contexto social em que a criança se constitui como aluno. Não há, em sua avaliação, teorias gerais sobre a criança ou o ser humano que possam substituir esse conhecimento.

Além disso, vale ressaltar que, no caso da teoria de Piaget, a finalidade da educação seria o pleno desenvolvimento das capacidades psicológicas das crianças e dos adolescentes. Este pode ser um objetivo interessante, desde que proposto e avaliado no interior da escola, ou seja, a psicologia do desenvolvimento pode ter importantes contribuições para o meio educacional, mas as metas da educação não se restringem aos aspectos psicológicos do desenvolvimento infantil. Isto porque a educação escolar se estabelece e se consolida para além da psicologia científica. A instituição escolar, como parte de um determinado momento histórico e cultural, constitui-se nos âmbitos político, econômico, social e até mesmo psicológico.

Na análise de Carvalho (2001), a tarefa educacional, sob o ponto de vista do contexto escolar, é desenvolver tradições públicas presentes nos conteúdos, valores e procedimentos da instituição. Dessa forma, um programa educacional não pode ser 
elaborado a partir, e exclusivamente, de referenciais psicológicos, pautados no desenvolvimento individual.

O autor destaca, ainda, que os conceitos e referenciais psicológicos que geraram recomendações relativas à ação educativa não tiveram origem em uma análise específica das condições concretas do contexto e da vida escolar. As teorias psicológicas pretendem, em geral, compreender outros aspectos da realidade:

O mínimo que se espera de um discurso que se proponha a modificar um conjunto de práticas sociais historicamente solidificadas, como as escolares, é que ele as conheça em suas manifestações mais típicas ou freqüentes, em seus condicionantes e resultados e, a partir desse conhecimento, aponte alternativas e as justifique, levando em consideração os valores e determinantes históricos a elas associados (Id. Ibid., p. 125).

Por isso, provavelmente, os cursos de formação não tenham como resultado a modificação das práticas dos professores. Evidentemente contribuem de forma significativa para que eles expliquem a realidade escolar a partir dos modelos tradicionais de desenvolvimento infantil e almejem propostas individuais de ensino, promovendo, assim, ações que inviabilizam atingir as metas educacionais coletivas. Essa é a psicologia aprendida, que impossibilita a competência crítica para avaliar e propor discussões no âmbito coletivo da educação escolar. Busca-se reformar a escola a partir de conhecimentos sobre desenvolvimento psicológico da criança, abstraindo-a deste contexto social muito mais amplo que é a instituição. Tomando como exemplo o construtivismo, Carvalho (2001, p. 119) conclui que:

Concebidos e aplicados como elementos de uma teoria que visa a reformar práticas escolares que lhe são desconhecidas, os slogans e as recomendações didáticas do construtivismo podem resultar - e talvez já tenham resultado - em uma desorganização das práticas docentes, com prescrições incapazes de oferecer oportunidades reais de transformação da ação educativa, dentre outros fatores porque as desconhecem em sua concretude e em suas especificidades institucionais e históricas (grifo do autor).

Neste sentido, a mera posse de informações sobre desenvolvimento cognitivo de uma criança não transforma ou condiciona as práticas pedagógicas de um professor. A 
técnica, o instrumento, o receituário até podem ser vistos como meios eficazes de resolver problemas, mas não dão conta deste objetivo. Apenas o conhecimento sobre a realidade escolar, em seus vários determinantes, de forma ampla e crítica, possibilita a transformação das práticas pedagógicas.

O construtivismo, como outras teorias de desenvolvimento cognitivo, trouxe para o discurso educacional novas técnicas didáticas e metodologias de ensino, com o fim de favorecer as potencialidades psicológicas das crianças. Mas, esqueceu-se da escola, de seus determinantes culturais, sociais e históricos, dos professores e até mesmo dos alunos:

[...] se o construtivismo - ou qualquer outra linha de investigação em psicologia - pretende contribuir de forma significativa para os discursos pedagógicos, é preciso que o foco de suas investigações se volte de forma direta para esse fenômeno particular e concreto que é o "mundo escolar", de forma que seja possível ultrapassar a mera transposição mecânica de conceitos e perspectivas que o tem caracterizado. Caso contrário, o construtivismo, a exemplo de tantas outras correntes educacionais que se alternam nos modismos pedagógicos, nunca passará de uma retórica abstrata e inconseqüente, porque incapaz de aumentar nossos conhecimentos sobre as instituições escolares e inepto para renovar seus fundamentos e práticas, pela simples razão que os desconsidera em suas características históricas e institucionais e em seus compromissos éticos e políticos (Id. Ibid., p. 127).

Formar educadores a partir de conhecimentos sobre desenvolvimento psicológico e esperar que transformem suas práticas em conseqüência desse processo, significa compreender a formação de maneira, no mínimo, restrita. A psicologia certamente, como veremos, tem contribuições significativas para dar à formação e à escola, mas a educação não se limita a aspectos psicológicos do desenvolvimento infantil. Ela pode iniciar suas contribuições na formação desmistificando o ensino preceptorial, os preconceitos dele decorrentes e favorecer o entendimento de processos de ensino e de aprendizagem no mundo escolar.

Ao tratar das dificuldades de exercer o seu ofício - ensinar - os depoentes apresentam-se contaminados por uma concepção de ensino baseada na relação dual professor-aluno. Como a teoria que lhes é ensinada não os instrumenta para isso - pois nada pode instrumentá-los para o ensino individualizado em classes de trinta a quarenta 
alunos - ela é vista como inútil, abstrata. E de fato eles têm razão, pois grande parte das teorias da aprendizagem e do desenvolvimento tem por objetivo instrumentar o professor nessa relação dual que marca a Pedagogia Moderna, até a Escola Nova e o Construtivismo. Eles compartilham, portanto, uma concepção oficial da relação pedagogia-psicologia: a segunda é instrumento da primeira, para que o ensino seja eficiente, produtivo, ajustando-se como luva ao nível do desenvolvimento de cada um dos alunos.

Compartilhando da análise de Carvalho, Azanha (1995abc, 1998, 2000) discute a falência do sistema de preparação de professores fundamentado numa relação pedagógica preceptorial. O autor (1998) diz que este modelo se constituiu como uma relação educativa da elite em seus primórdios, mas que a escola pública de hoje não pode mantê-la. A preceptoria, todavia, deixou vestígios na pedagogia, nas teorias de aprendizagem e na concepção de professor: "Por isso, talvez, é que continuamos a insistir numa formação docente preceptorial na qual além do domínio da disciplina a ensinar, prevalece uma visão psicológica do educando” (p. 18).

A visão preceptorial, neste sentido, é mantida pela compreensão do aluno como um indivíduo psicológico. Quando o ensino não vai bem, substitui-se uma orientação psicológica por outra, considerando que a tarefa de ensinar é apenas a aplicação de uma metodologia. A pretendida qualidade do ensino:

[...] foi interpretada como uma questão a ser resolvida metodologicamente, por meio de procedimentos de ensino supostamente mais eficazes porque seriam apoiados em teorias psicológicas do desenvolvimento e da aprendizagem. O impacto dessas idéias influiu fortemente nos cursos de licenciatura, ampliando substantivamente o espaço curricular de disciplinas vinculadas às temáticas específicas de feição metodológica e psicológica. Obviamente, tudo isso reforçou uma concepção de ensino preceptorial fundada numa relação pessoal entre professor e aluno (AZANHA, 2000, p. 9).

A relação pedagógica preceptorial, de acordo com Azanha (2000), nunca foi uma relação escolar, pois se dá entre duas pessoas, abstraída do contexto institucional. O fato essencial é que o preceptor é um agente da família e a escola é um agente social. 
Considerar que a relação preceptorial deve orientar o ensino pressupõe, também, que a formação fixa-se na figura individual do professor. Azanha $(1998,2000)$ adverte, porém, que a formação deve contemplar a compreensão da situação escolar e, neste sentido, deve ser da escola e não do professor individualmente:

[...] a escola pública é uma instituição social muito específica com uma tarefa de ensino eminentemente social que, por isso mesmo, exigiria um esforço coletivo para enfrentar com êxito as suas dificuldades porque essas dificuldades são antes institucionais que de cada professor. Mas, de fato, o que se tem é um conjunto de professores preparados bem ou mal, para um desempenho individualizado e que, por isso, resistem à idéia de que os próprios objetivos escolares são sócio-culturais e que até mesmo o êxito no ensino de uma disciplina isolada deve ser aferido em termos da função social da escola (AZANHA, 1998, p. 18).

O aperfeiçoamento em metodologias pedagógicas ou em uma disciplina específica, assim, não contempla a formação para a tarefa coletiva do ensino no contexto de um projeto escolar. Azanha (2000) analisa que o exercício da profissão no quadro institucional da escola deve ser o centro das preocupações teóricas e das atividades práticas nos cursos de formação. O professor precisa ser formado para enfrentar os desafios da nova escola contemporânea.

Esta nova escola formou-se, de acordo com o autor, a partir da expansão das matrículas no ensino fundamental na década de 1960, inviabilizando a atividade de ensino fundada na relação professor-aluno, embora esta concepção ainda seja predominante nos cursos de licenciatura para os quais basta ter o conhecimento de uma disciplina e ser preparado didaticamente. A preparação didática se dá, geralmente, nesta perspectiva, com a aquisição de teorias psicológicas, criticada por Azanha (2000, p. 6):

A idéia de que ensino eficaz é basicamente a aplicação competente de um saber metodológico, epistemologicamente fundamentado em outros saberes, principalmente de natureza psicológica, é altamente discutível. Teorias da aprendizagem, da inteligência e do desenvolvimento cognitivo e emocional da criança e do adolescente aparecem, entram em moda e saem de moda. Pouco há de seguro, nessas áreas do conhecimento, que permita fundamentar a formação do professor. 
Os cursos de preparação para o magistério realizam, assim, uma caracterização abstrata de uma formação ideal, desconsiderando, dentre outras coisas, as especificidades de cada região, escola, cidade, estado, uma vez que o Brasil possui grandes variações culturais, econômicas e sociais.

Partindo do pressuposto de que a formação deve ser da escola e não do professor individual, considerando desde as políticas de administração do ensino público até a imposição de modelos pedagógicos que visam ao ensino eficaz, Azanha (1995b) enfatiza que a falência da escola pública não será resolvida com a substituição de uma proposta curricular por outra, pois não se trata de realizar experimentações pedagógicas. Refletindo sobre os cursos de licenciatura da Universidade de São Paulo, afirma: “[...] Acreditamos que nenhuma alteração curricular, isoladamente, modificará o quadro atual do problema da formação do licenciado. O problema, como já ficou claro anteriormente, não é basicamente pedagógico, mas institucional” (p. 60).

A raiz dos problemas da formação não se situa essencialmente no plano pedagógico, já que se refere às questões da política educacional. A didática e a pedagogia, na avaliação do autor, não são suficientes para habilitar as pessoas a ensinar com êxito:

[...] Tudo se passa como se a formação do professor devesse instrumentá-lo com métodos e técnicas, quando talvez fosse muito mais interessante preparar o professor a partir da discussão de questões substantivas de educação nos seus aspectos filosóficos, históricos, sociais e políticos. Aqui, ainda é importante assinalar que a visão tecnológica da formação do professor tem extravasado o âmbito do ensino superior e contaminado toda a política de aperfeiçoamento do magistério executada pelos órgãos públicos de administração do ensino, como se apenas nesse aspecto o professor devesse ser atualizado (AZANHA, 1995a, p. 51).

Ao analisar o depoimento dos entrevistados, nota-se que a visão tecnicista está presente, além dos cursos de formação, inclusive nas expectativas dos professores. Consideram que lhes faltam recursos técnicos, metodologias, quase receitas que os habilitem a lidar com problemas concretos de aprendizagem. Não se dão conta de que a questão da qualidade do ensino é institucional, o que significa analisar a função social da 
escola e do professor, cujos pressupostos básicos têm sido descaracterizados por políticas cada vez mais descomprometidas com o ensino para o povo.

As dificuldades encontradas pelos depoentes para ensinar são depositadas, muitas vezes, na formação inadequada que prometeu, mas não cumpriu, habilitar os professores a resolver problemas, compreendendo o que se passa com cada criança. Na escola real, verificam a impossibilidade de ser um preceptor, mas desejam que alguém assuma este papel, pois consideram ser essa a única maneira de se ensinar adequadamente.

Tais idéias são reforçadas pelas políticas educacionais, nas quais cursos de aperfeiçoamento e reuniões pedagógicas centram-se no estudo de problemas cognitivos, emocionais e afetivos das crianças, apresentando novas tecnologias de ensino. Não há, nos diversos momentos de formação, o estudo sobre o aluno ${ }^{53}$, sobre a escola e a condição do professor. Como apontado por Azanha, a preparação para o magistério também pressupõe que o problema está na formação individual do professor, portanto, é ele quem deve adquirir conhecimentos, principalmente de natureza metodológica, para lidar com crianças. Esquece-se, assim, da escola e de sua formação.

Os cursos de aperfeiçoamento docente, segundo Azanha (1995c), têm por objetivo modificar a prática do professor para atingir níveis mais eficientes de qualidade do ensino, embora os especialistas que ministrem tais cursos, em geral, não realizem pesquisas sobre a escola - instituição - e desconheçam a prática que pretendem aperfeiçoar. As práticas de ensino passam a ser melhoráveis em condições abstratas:

A questão da qualidade do ensino é, pois, uma questão institucional. São as escolas que precisam ser melhoradas. Sem este esforço institucional, o aperfeiçoamento isolado de docentes não garante que essa eventual melhoria do professor encontre na prática as condições propícias para uma melhoria do ensino (AZANHA, 1995c, p. 204).

Para enfrentar a questão da qualidade do ensino oferecido nas escolas públicas, de acordo com o autor, é preciso enfrentar a questão da formação de professores, entendida como um processo que deve superar a relação preceptorial e que não se

\footnotetext{
${ }^{53}$ Verifica-se, na análise dos depoimentos, o predomínio do estudo, nos cursos de formação, sobre a criança e seu desenvolvimento independente da educação escolar, com base em teorias psicológicas.
} 
constituiu como mera aquisição de conhecimentos psicológicos ou metodologias mais eficazes de ensino. Azanha (1998, p. 16) conclui que os cursos de formação:

[...] foram organizados a partir de uma concepção do trabalho docente, como se este consistisse simplesmente em ensinar alguma coisa para alguém. Para realizar com êxito essa tarefa, o futuro professor - um meio especialista em alguma disciplina - aprende algumas noções de didática geral e especial, de psicologia da aprendizagem e legislação. A parte prática da formação é, supostamente, completada por estágios junto a um professor da disciplina em questão. No fundo, essa formação pressupõe que o professor será um preceptor que deverá ensinar algo a alguém numa relação individualizada. Não se trata de fazer uma caricatura, mas de propor uma hipótese, a de que nossos cursos de licenciatura ainda não conseguiram focalizar a relação educativa no ambiente em que ela realmente ocorre, isto é, na sala de aula que, por sua vez, integra-se numa escola. O chamado "processo ensino/aprendizagem”, por exemplo, é uma abstração. O professor individual que ensina e o aluno individual que aprende são ficções.

Analisar a formação de professores precarizada pelas políticas neoliberais e limitada pela visão preceptorial de ensino, construída e fortalecida pela psicologia, requer a delimitação de uma concepção de educação e de suas finalidades. Além disso, é preciso compreender em que contexto ocorre a supervalorização da prática na formação em detrimento da teoria.

\subsection{A finalidade da educação e a formação dos formadores}

Adorno (2003) afirma que educação não é modelagem de pessoas a partir de seu exterior, nem tampouco mera transmissão de conhecimentos. É, pois, a produção de uma consciência verdadeira que pode lutar contra a barbárie, contra a violência primitiva que destrói o próprio homem. Assim, a primeira exigência para a educação é a de que Auschwitz - a barbárie - não se repita. Por barbárie o autor compreende o preconceito delirante, o genocídio, a tortura e a opressão. A produção da consciência verdadeira, desta forma, promove a autonomia, a reflexão e a autodeterminação, possuindo importância política, uma vez que uma democracia verdadeira demanda pessoas 
emancipadas. O objetivo educacional, todavia, não é mais compreensível por si mesmo, segundo Adorno, o que denota a perda das condições de emancipação.

Resistir à barbárie, de acordo com Crochik (1992), é pensar por si próprio, atingir um estado de maioridade, de autodeterminação. A luta contra a barbárie na educação só possui sentido se ela tiver como finalidade a auto-reflexão crítica. Neste sentido, uma das tarefas da educação seria "[...] mostrar como o homem se constitui e se transforma em relação a seu mundo, ou seja, que ele não é imutável” (Id. Ibid., p. 344).

A exigência política, apontada por Adorno (2003), que se faz para a educação de que construa consciências verdadeiras para que a barbárie não se repita, está muito longe de ser alcançada quando analisamos o depoimento dos sete professores entrevistados, tanto no que se refere à sua formação, quanto no que ocorre no cotidiano escolar.

Inúmeros são os exemplos de barbárie narrados pelos depoentes, mesmo que não os qualifiquem dessa forma. Alguns estão presentes em sua formação: concepções de normalidade e anormalidade dos conteúdos pedagógicos, promovendo a patologização e exclusão das crianças que não se encaixam em determinados moldes científicos; a falsa habilitação dos docentes para realizar diagnósticos psicológicos com o fim de classificar os alunos; a inclusão de crianças com necessidades especiais, jogadas nas escolas, sem que o professor saiba ao menos o que fazer com elas; a exposição de preceitos psicológicos, de forma dogmática, sobre desenvolvimento infantil, como receitas para serem aplicadas pelos futuros professores; o abandono da teoria em favor do tecnicismo, dentre vários outros aspectos.

Se a educação é, de acordo com Adorno (2003), condição importante de combate à barbárie ou de promoção do desenvolvimento da consciência emancipada, a fim de gerar resistência contra a violência primitiva dos homens sobre os homens, a formação do formador torna-se tema fundamental. Ele é responsável também por contribuir para a construção de consciências verdadeiras e emancipadas, além de combater a barbárie na e da escola. Isto se dá pelo desenvolvimento do pensamento, da reflexão, da autonomia. Cabe saber se sua formação tem lhe proporcionado momentos de pensar e, também, analisar se os cursos de formação têm cumprido a função destacada anteriormente por Crochik (1992). 
O que foi apresentado pelos depoentes, contudo, revela a naturalização do que é histórico e a imutabilidade do que é essencialmente dinâmico. Denotam, ainda, a falta de possibilidades de reflexão e da construção da autonomia do pensar. Não há mais formação intelectual e cultural a quem pretende ser um formador. Os cursos ensinam modelos pedagógicos fundamentados em propostas psicológicas, como receitas para se conseguir um ensino eficaz, desconectados do contexto educacional, além de preconceitos já superados pela própria ciência que inviabilizam o ensino das classes populares. Como são raros os momentos de formação cultural nos quais o docente possa olhar o contexto escolar em que trabalha e, por meio de seus recursos intelectuais, transformar sua realidade, ele sente-se perdido, pois as receitas não funcionam, não são aplicáveis a seus alunos. O próprio pensamento utilitário baseado em critérios de aplicabilidade sobre a eficácia de metodologias de ensino não é questionado.

A formação, conforme apresentada pelos depoentes, não só em psicologia, mas de maneira geral, prioriza a técnica. No que se refere à psicologia, especificamente, almejam a utilidade - que denominam "prática" - o "saber fazer” para obter resultados, como crianças alfabetizadas e disciplinadas. Como não ensinam a pensar, fazer experiências intelectuais, refletir, problematizar, investigar, desconfiar, produzir, os cursos promovem um modo de raciocínio instrumental. Nele, educadores aprendem a procurar meios - metodologias de ensino, modelos de aprendizagem, forma de controle da disciplina - para atingir resultados questionáveis, como o alcance de metas educacionais vindas não se sabe de onde, que desconsideram a realidade escolar. Quando se voltam ao conteúdo que aprenderam, percebem sua ineficácia e atribuem tal fato à ausência de estudos de caso, de prática, de discussão de casos reais da escola real. Consideram que o conteúdo visto foi “muito teórico” e que “teoria não leva a nada”.

Em primeiro lugar, é preciso apontar que não estiveram nem próximos à teoria: tiveram contato com autores e textos da psicologia e da educação de maneira imprecisa e superficial, geralmente com a apresentação de fragmentos de propostas pedagógicas vinculadas a esses autores. Além disso, aprenderam, aí sim de maneira eficiente, a pensar de forma instrumental, pragmática, buscando metodologias, maneiras de agir, receituários e também, como visto anteriormente, aprenderam uma psicologia que fundamenta a visão preceptorial de ensino. O problema consiste, na avaliação dos 
depoentes, na impossibilidade de transposição dos modelos de Vigotski, Piaget, Wallon, Freud $^{54}$, ou quem quer que seja, para a escola, porque a maneira como foram apresentados pressupõe o ensino individualizado, que lá não existe, mesmo que o desejem. A escola é espaço de ensino e aprendizagem coletivos.

Os depoentes sabem que há problemas na escola; vêem o número absurdo de crianças que, na quarta-série do ensino fundamental, não conseguem ler e escrever, quem dirá fazer as quatro operações matemáticas; enxergam o abandono destes alunos nas salas de aula; criticam as políticas educacionais de inclusão dos portadores de necessidades especiais; denunciam, inclusive, a precariedade de sua formação. Mas, apesar disso tudo, sua crítica é fundamentada em um modelo instrumental de pensamento: a escola vai mal, e muito mal, porque, dentre outras questões políticas e estruturais, não se encontrou um modo adequado de ensinar; os professores não tiveram contato com formas eficazes de conhecimento sobre desenvolvimento cognitivo e afetivo. No que se refere ao ensino, falta na formação, de acordo com os depoentes, a prática - os meios.

Crochik (1992) ressalta que um dos obstáculos à reflexão autônoma encontra-se nessa formação tecnicista, fundamentada na ciência em sua versão positivista que cultua os fatos, além da indústria cultural e das relações pessoais despersonalizadas. Afirma que:

[...] A educação se dá em nome da civilização e do indivíduo, para que ambos possam ser preservados; ela não deve ser mera fonte de autoconservação individual, através do desenvolvimento das potencialidades individuais para o trabalho, e nem mera fonte de auxílio para a reprodução social. Ou seja, não deve se calcar somente na formação técnica ou profissional (Id. Ibid., p. 343).

Como explicar, então, o predomínio do raciocínio instrumental na formação de professores? De onde vem o desejo por saber fazer para controlar o processo de ensinoaprendizagem?

\footnotetext{
${ }^{54}$ Vale ressaltar que não estamos desconsiderando o valor destes autores da psicologia para o campo educacional. Porém, esta não é a questão aqui. O que se discute é a distância entre o que cada um desses teóricos produziu e o que disto foi apresentado aos depoentes. Além disso, como visto anteriormente, é necessário refletir e analisar sobre as possíveis repercussões da transposição mecânica de teorias do desenvolvimento cognitivo e emocional individual para o contexto escolar, como proposto por Carvalho (2001).
} 


\subsection{O predomínio da racionalidade instrumental na formação}

No processo histórico da modernidade, de acordo com Leopoldo e Silva (1997), a razão esclarecedora foi condição de emancipação do homem em relação às forças da natureza e aos dogmas alheios ao domínio da pura razão, como os mitos. Esta finalidade racional está presente desde Bacon e Descartes: “Conhecer emancipa porque o conhecimento traz consigo o domínio da realidade” (Id. Ibid., p. 11).

A conseqüência necessária para se atingir o domínio da realidade seria possuir o domínio técnico da natureza. A vinculação, no projeto de Bacon e Descartes, entre teoria e técnica, portanto, seria o único meio de aprimoramento da vida. A razão, por meio de um mesmo método objetivo - o físico-matemático - deveria conhecer todos os objetos, mesmo sendo tão distintos, como a Física e a Moral, para atender o estatuto de cientificidade. Assim, “[...] o progresso do conhecimento ocorre de maneira solidária a uma restrição do exercício da racionalidade teórica” (Id. Ibid., p. 15).

O que antes seria condição de domínio da natureza para o aprimoramento da vida, passa a ser condição de domínio do próprio homem, uma vez que, para conhecê-lo, seria necessário submeter o objeto de estudo das ciências humanas - o próprio sujeito ao paradigma de objetividade que teve seu auge com o positivismo.

A razão instrumental, dessa forma, ganhou uma dimensão totalitária e a prática passou a ser entendida como derivação da teoria, mera aplicação técnica do conhecimento teórico-instrumental. A maior conseqüência, segundo o autor, do paradigma físico-matemático foi a dissolução da realidade em objeto do conhecimento. A razão instrumental abandonou o sujeito e, no caso específico da psicologia, transformou o sujeito em objeto manipulável, trouxe a representação da pessoa como coisa. Há, portanto, a identificação entre racionalidade e reificação. Para a psicologia, a reificação do sujeito tornou-se a única possibilidade de conhecê-lo.

Na razão instrumental, então, conhecer é saber fazer; é para controlar que se conhece. O progresso do conhecimento é o progresso do domínio, fazendo com que a intencionalidade pragmática da consciência intelectual seja conhecer para dominar. 
O autor argumenta que a Teoria Crítica da Escola de Frankfurt traz a possibilidade de se considerar as contradições presentes no modelo tradicional da razão instrumental, identificando o caráter histórico da própria razão e, por isso, suas contradições, questionando a homogeneidade e uniformidade do objeto. Nela, conhecer o homem é conhecer o sujeito histórico e não um sujeito dado:

[...] para a teoria crítica, a realidade é produzida pelos sujeitos enquanto agentes históricos. O que diz respeito ao homem nunca pode ser tomado como um dado natural. Tomar o homem como produtor das práticas que constituem a sua realidade é tirá-lo da esfera dos objetos físicos-inertes, é considerar a impossibilidade de separar, no sujeito, o que ele é do que ele faz, entendendo que a ação humana se distingue da ação dos objetos naturais por ser dotada de intencionalidade (LEOPOLDO E SILVA, 1997, p. 25, grifo do autor).

A racionalidade técnica identifica, então, meios com fins. A confiança na razão e no seu progresso ilimitado enfraquece, segundo o autor, a visão crítica da racionalidade. A razão torna-se absoluta, exprimindo-se por meio da instrumentalização. O progresso, identificado à razão, traz o regresso e a subordinação do homem às próprias condições de dominação por ele criadas: “[...] esta representação reificada que o sujeito tem de si mesmo é que opera a regressão de uma pretensa emancipação a uma total submissão e controle, numa realidade histórico-social totalmente administrada pelos parâmetros funcionais da razão instrumental” (Id. Ibid., p. 21, grifo do autor).

Crochik (1990, p. 154) partilha dessa mesma tese:

Assim, o processo de desenvolvimento social se legitima em si mesmo, é um fim em si próprio representado pela administração racional, uma administração tão racional, que a leva à irracionalidade, por esquecer que ela é meio para a felicidade humana. Mas, por levar o seu controle da natureza a um controle extremo sobre o homem, impede a individualização deste. O sistema da razão formal, de servo se transforma em senhor, o animal racional apartado de sua especificidade, se aliena de si mesmo ao não se diferenciar neste formalismo. E, assim, à sociedade madura corresponde $\mathrm{o}$ adulto infantilizado, e à identidade heterodirigida corresponde o indiferenciado.

Neste sentido, quanto mais a técnica pode substituir o trabalho manual, ampliando as possibilidades de trabalho intelectual, este segue apenas a racionalidade 
técnica e deixa de ser pensamento. A técnica, então, reprime o pensamento, ao mesmo tempo em que provém dele.

A realidade administrada pela razão instrumental invade diversos âmbitos da vida humana e neles se incluiu a formação, compreendida como a formação do indivíduo na sociedade, em seus aspectos sociais, políticos, culturais e éticos. A preparação de professores faz parte desse contexto amplo, no qual, desde o século XIX, tem predominado o "saber fazer”. A técnica necessária para que o homem conhecesse e dominasse o mundo e, por meio disso, se emancipasse, tornou-se o aprisionamento do homem, pois abandonou sua relação com a teoria e passou a ser mera aplicação instrumental dela.

Para Adorno e Horkheimer, segundo Leopoldo e Silva (1997), a liberdade na sociedade é inseparável do pensamento esclarecedor, mas as instituições da sociedade e as formas históricas concretas contêm as condições de regressão ao mesmo tempo em que contêm as de esclarecimento: “[...] a emancipação se converte em submissão, na medida em que o progresso da razão instrumental coincide com a regressão do humano à categoria de coisa” (Id. Ibid., p. 23).

Neste sentido, ao analisar a formação de professores, como parte da regressão do esclarecimento, compreende-se o predomínio da visão instrumental que vem para habilitar os docentes a executar modelos pedagógicos com o objetivo de atingir a eficácia do ensino. O pensamento, a reflexão, a própria razão são apartados das finalidades educacionais. A formação destina-se a "saber fazer", ao invés de "fazer saber”.

Crochik (1990) enfatiza que o tecnicismo leva a uma posição anti-teórica e à busca de soluções imediatas, não refletidas. Esta ideologia da racionalidade tecnológica fortalece o pensamento e o comportamento padronizados, cujo critério é a eficácia sobre o meio. Além disso, coloca-se no lugar de questões políticas e, nesta perspectiva, não se trata de modificar a sociedade, mas de aperfeiçoá-la. A alternativa imposta é o aperfeiçoamento técnico dos sistemas sociais: “[...] não se trata de modificar a sociedade, mas de aperfeiçoá-la, e, como a técnica traz, da Filosofia Positivista, a imagem da neutralidade, as contradições sociais são suspensas e a técnica adentra no cotidiano através de um processo de racionalização crescente” (Id. Ibid., p. 153). 
O mesmo ocorre no processo de formação: não se trata de questionar, refletir, transformar a formação, mas de aperfeiçoá-la. Para isso, organizam-se cursos de aperfeiçoamento e reciclagem que têm como finalidade a introdução de novas metodologias no trabalho docente. Perde-se a possibilidade da formação de uma consciência política; em seu lugar tem-se “[...] a consciência tecnológica, uma consciência que reduz a si mesmo e aos outros, a objetos técnicos. Não precisamos dizer que é o grau mais avançado da reificação” (CROCHIK, 1990, p. 153).

A administração total da sociedade baseada na eficiência técnica é, segundo Maia (2002), a generalização da racionalidade industrial para a sociedade como um todo. Há, portanto, um caráter totalitário da dominação social atual que invade, inclusive, o âmbito da formação. Esta, de acordo com Crochik (1990), tem sido mera aquisição de bens culturais e materiais.

Maia (2002) assinala que o avanço técnico permite uma produção em larga escala de mercadorias culturais. A indústria cultural, responsável por esta produção, administra também o tempo livre. A formação do indivíduo, dessa forma, submete-se ao controle da dominação econômica em todos os aspectos, inclusive nos momentos de ócio:

[...] A técnica que poderia libertar encontra-se historicamente atrelada às relações sociais de dominação - como o demonstra a 'dialética do esclarecimento' - o que impulsiona o desenvolvimento técnico em uma direção unilateral, a sofisticação da própria dominação. Isto é plenamente visível na indústria cultural, na manipulação consciente da consciência dos homens com o objetivo de justificar a dominação (Id. Ibid., p. 54-55).

A técnica não é neutra, mas também não está inerentemente vinculada à dominação. As relações históricas, todavia, mostram que quanto mais há progresso, com o desenvolvimento técnico, mais se aperfeiçoa a dominação. O avanço técnico, neste sentido, que poderia libertar o homem de diversas formas de trabalho massificadoras, o tem aprisionado.

Assim, a crise da articulação entre o processo de trabalho social e o processo de formação cultural promove a deformação, uma vez que o trabalho é alienado. Crochik (1992) afirma que: 
[...] De um lado, a tecnologia permite uma racionalidade maior na esfera de produção, de outro lado, ela se torna fetiche, tão logo a possibilidade de uma vida digna é ocultada. No seu exemplo [de Adorno], sobre alguém que constrói um sistema de trens para Auschwitz, não se importando com os fins de sua obra, mas com a sua perfeição, o autor revela as condições de frialdade existentes, que impedem o voltar-se para os outros. O homem impossibilitado de amar outra pessoa volta o seu amor para a técnica (p. 347).

A fetichização da técnica, com a conseqüente renúncia da teoria, inviabiliza a crítica imanente das condições sociais que promovem a deformação por meio do trabalho alienante. Maia (2002) destaca que a crítica imanente seria aquela cujo ponto de apoio é o próprio objeto/condição criticado. Isto significa mostrar os elementos de verdade e de inverdade do conteúdo ideológico. Perde-se a autonomia:

O espírito perde sua relativa autonomia que, por problemática que fosse, ainda permitia alguma crítica ao existente, e torna-se servil, impotente, preso à empiria, e acaba por confirmar, dessa forma, a eficiência do todo. A possibilidade de crítica está vinculada à autonomia do espírito, uma autonomia que possa reconhecer suas determinações na realidade concreta e seus limites, mas que também permita o esforço da imaginação, o entrelaçamento entre o trabalho e o prazer. É justamente essa forma de atividade que se encontra vedada; os homens se adaptam ao existente em nome deste, e a ideologia torna-se um mero conjunto de formas estereotipadas de comportamento adequados à reprodução do existente, presas à lógica da autoconservação a qualquer custo (MAIA, 2002, p. 63).

\subsection{O retorno à teoria como resgate da liberdade}

O resgate da autonomia pode ser possível pelo retorno à teoria; para tanto, segundo Adorno (1995), a teoria precisa desprender-se do pragmatismo, o que significa que o critério de validade de um conhecimento não pode ser sua utilidade prática. A formação, como auto-reflexão crítica que conduz à autonomia, deve passar pela análise da relação entre teoria e prática.

Para o autor, a característica de nossa época é a aversão à teoria - seu atrofiamento - que gera a conseqüente fragilidade da práxis: os homens passam a desejar 
transformar o mundo sem interpretá-lo. O conceito de práxis, assim, pressupõe a existência de um agente livre e autônomo que não mais existe; por isso a relação entre teoria e práxis se transforma. A razão torna-se o que o autor denomina "medula da práxis”.

O verdadeiro conceito de práxis - o esforço de sair da barbárie - se perde na formação do indivíduo com a destruição da teoria pelo primado da razão prática: “[...] Práxis sem teoria, abaixo do nível mais avançado do conhecimento, tem que fracassar e, segundo seu conceito, a práxis deveria realizá-lo. Falsa práxis não é práxis” (ADORNO, 1995, p. 211).

Falta auto-reflexão na práxis quando ela se transforma em fetiche, isto é, o espírito da práxis passa a ser a própria falta de espírito. Dessa forma, a práxis está cada vez mais vazia de conceito e só conhece ela própria: a práxis pela práxis. Mas Adorno (1995, p. 213) adverte: “Sem dúvida, é ilusória a dispensa do espírito em relação ao trabalho material, pois o trabalho material é um pressuposto para a própria existência do espírito”.

A divergência entre teoria e práxis surge com a separação entre trabalho físico e intelectual. A práxis, tal como se apresenta na modernidade, nasce com o trabalho. Propagar esta antítese entre teoria e prática, segundo o autor, serve para denunciar/renunciar à teoria:

[...] O espírito burguês reúne a autonomia e a aversão pragmatista pela teoria tão antinomicamente quanto a sociedade que o sustenta. $\mathrm{O}$ mundo, que a razão subjetiva tendencialmente só se limita ainda a reconstruir, na verdade deve ser continuamente transformado conforme sua tendência à expansão econômica e, contudo, sempre permanecendo o que é. O que mexe com isso é amputado do pensar: sobretudo, a teoria que quer algo mais que reconstrução. Dever-se-ia formar uma consciência de teoria e práxis que não separasse ambas de modo que a teoria fosse impotente e a práxis arbitrária, nem destruísse a teoria mediante o primado da razão prática [...] Pensar é um agir, teoria é uma forma de práxis [...] (ADORNO, 1995, p. 204).

A auto-reflexão significa, na perspectiva do autor, a interrupção da ação cega que tem seus fins fora de si, pois a substituição dos fins pelos meios substitui o próprio homem. Neste sentido, a instrumentalização colocada no lugar da teoria, faz com que os homens desenvolvam pseudo-atividades. 
Adorno (1995) afirma que, para os práticos, o pensamento causa fadiga, dá trabalho, uma vez que quem pensa opõe resistência. Quando a práxis serve apenas para responder “o que fazer”, ela transforma-se em ideologia.

Retornando aos depoimentos dos professores entrevistados, é possível encontrar como eixo de sua descrição sobre a formação em geral e, especialmente, em psicologia, a dicotomia entre teoria e práxis, inclusive a perda absoluta de sentido destes conceitos. Teoria é identificada com idéias presentes em textos que não possuem vínculo com a realidade, ou seja, o critério de validade do conhecimento é exclusivamente a aplicabilidade ou utilidade. Prática, por sua vez, é a ação arbitrária, irrefletida, imediata, que busca soluções. Neste caso, não é possível denominar esta ação como práxis.

Na avaliação dos depoentes falta na formação o “saber fazer” e a prática, então, serve apenas para responder a esta pergunta. Adorno (1995) analisa que a supervalorização da prática ocorre quando se perdeu a capacidade de se fazer experiências ${ }^{55}$ :

[...] O que, desde então, vale como o problema da práxis, e hoje novamente se agrava na questão da relação entre teoria e práxis, coincide com a perda de experiência causada pela racionalidade do sempre-igual. Onde a experiência é bloqueada ou simplesmente já não existe, a práxis é danificada e, por isso, ansiada, desfigurada, desesperadamente supervalorizada (ADORNO, 1995, p. 203-204).

O ativismo, dessa forma, conduz à regressão refletida no depoimento de todos os professores entrevistados. Em seu processo formativo, teoria e prática são vistas de maneira dissociada: não se percebe que a ação prática só ocorre por meio da teoria, ou ainda, como aponta o autor, que o pensamento sempre que alcança algo importante, produz um impulso prático, mesmo que não seja visível de forma imediata. Ao contrário, a mediaticidade deve ser a característica do pensamento: este só ocorre quando não se aceita passivamente o desde sempre dado.

A teoria, segundo o autor, deve ser autônoma, mas ela não existe sem a práxis e esta não existe sem aquela. Elas, portanto, não são a mesma coisa, nem absolutamente distintas: sua relação é de descontinuidade. Vale ressaltar que a transposição direta da

\footnotetext{
${ }^{55}$ Este conceito será analisado mais detalhadamente a seguir. Por ora, é importante ressaltar que a experiência possibilita a autonomia do pensamento, a auto-reflexão.
} 
teoria à práxis destrói a teoria: “[...] O dogma da unidade entre teoria e práxis é, em oposição à doutrina a que se reporta, adialético: ele capta simples identidade ali onde só a contradição tem chance de ser frutífera” (ADORNO, 1995, p. 227).

Explicitar contradições ao invés de omiti-las deveria, neste sentido, constituir-se como finalidade de qualquer processo formativo, além, é claro de resgatar a liberdade que o pensamento, a auto-reflexão - enfim, a teoria - podem produzir.

Todavia, há na formação a crise da prática, explicitada pela angústia do não saber o que se deve fazer. Então, abandona-se a teoria e, como pode ser observado nos depoimentos, a práxis transforma-se em mero tecnicismo, busca por metodologias que se encaixem nos problemas pedagógicos enfrentados. Perdem-se os fins e até mesmo os meios. No entanto, encontrar os meios mais adequados para a solução imediata de dificuldades continua sendo o objetivo principal. Adorno fala do fascínio exercido pela práxis: “[...] Esta é uma dialética desesperada: do fascínio que a práxis impõe aos homens não é possível escapar senão através da práxis, ela porém, ao mesmo tempo apática, estreita, carente de espírito - contribui enquanto tal para reforçar esses fascínio” (Id. Ibid., p. 207).

A busca desesperada de meios ou táticas, de maneira irrefletida, aliena-se dos fins, aniquila qualquer possibilidade de discussão. O primado da práxis, segundo o autor, manifesta-se como o primado da tática.

O que não se percebe é que qualquer pensamento/reflexão tem seu telos prático. A teoria pode gerar a liberdade desde que não seja orientada pelo fascínio exercido pela prática, ou seja, desde que não tenha como finalidade resultados encomendados. A superação da dicotomia entre teoria e práxis e a conseqüente aversão à teoria só pode, para o autor, ocorrer pelo resgate da própria teoria:

[...] Os que não param de gritar: Demasiado abstrato!, empenham-se num concretismo, numa imediatez, que estão abaixo do nível dos meios teóricos disponíveis. Isso favorece a práxis aparente. Os mais finórios dizem [...] que a teoria é repressiva; e qual atividade no interior do 'status quo' não o seria a seu modo? O agir imediato, no entanto [...] está incomparavelmente mais próximo da repressão do que o pensamento, o qual ajuda a respirar. $\mathrm{O}$ ponto arquimédico: como é possível uma práxis não-repressiva, como navegar entre as alternativas espontaneidade e organização; isso só pode ser 
descoberto, se é que é possível, através da teoria e não por outra via (ADORNO, 1995, p. 223, grifo do autor).

Ao contrário do que relatam os depoentes sobre seu processo formativo, o que falta na formação para o magistério é teoria. Esta traz a possibilidade de pensar, de refletir, de agir de forma mediatizada, de orientar os meios de acordo com os fins, ou seja, de estabelecer a relação necessária entre teoria e práxis.

O concretismo e a imediatez em que estão envolvidos os depoentes os impedem de avaliar que, em sua formação, não realizaram experiências teóricas, ao contrário do que imaginam. Qual a importância, então, do pensamento, da auto-reflexão, do retorno à teoria na formação do educador?

\subsection{De que vale a teoria? - a construção de experiências intelectuais}

O crime cometido na formação contra os professores depoentes e, certamente, contra muitos outros, foi não lhes ensinar a pensar, da maneira como define Adorno (2003), ou seja, a fazer experiências intelectuais, nas quais a formação se oporia à vida normatizada, administrada, deixando marcas intensas e duradouras. Mas este foi só um dos crimes.

A educação para a experiência promoveria a educação para a emancipação. Os cursos de formação, sejam eles superiores, técnicos, de preparação pedagógica ou compensação, ensinam ciência - ou nem chegam perto disto - e abandonam a reflexão: “a ciência como ritual dispensa o pensamento e a liberdade” (Id. Ibid., p. 70).

Falta, portanto, experiência na formação dos professores, entendida como "um processo auto-reflexivo, em que a relação com o objeto forma a mediação pela qual se forma o sujeito em sua 'objetividade’” (MAAR, 2003, p. 24).

De acordo com o autor, a característica da modernidade é a crise da formação cultural, a deficiência da experiência cultural continuada. Por isso, condições sociais impedem a formação. Auschwitz simboliza a tragédia da formação na sociedade capitalista. O mundo moderno - que reprime o diferenciado em prol da uniformização da sociedade administrada, reprime o processo em prol do resultado - promove o 
travamento da experiência. Assim, o processo de coisificação impede a experiência formativa. O esclarecimento, como momento subjetivo do conhecimento, não ocorre. Na formação, os professores são impulsionados a buscar resultados, a querer soluções, a prática.

Maar (2003) afirma que a semiformação seria a incapacidade de fazer experiências. A ausência destas conduz à barbárie. Há dois momentos da experiência: o primeiro é materialista, é a disponibilidade de contato com o objeto, a abertura ao empirismo. O segundo momento é histórico, é o tornar-se experiente, aprender pela via mediada da elaboração do processo formativo, reelaborar a relação do passado com o presente para apreender o presente como histórico. Por isso, a experiência formativa não se esgota na relação formal do conhecimento; implica na transformação do sujeito no curso de seu contato com o objeto, sendo necessário tempo de mediação e continuidade dos processos formativos, ao contrário do imediatismo e da fragmentação das vivências.

A crítica imanente fica impossibilitada, de acordo com autor, pela perda da capacidade de realizar experiências formativas, conduzindo à barbárie. A educação sozinha não daria conta de combater a violência: é preciso alterar as condições objetivas da sociedade. Assim, a educação contra a barbárie, com sentido emancipatório, necessita também de intervenções objetivas, materiais, no nível das condições sociais e psicológicas em que se desenvolve a barbárie. A formação inviabiliza-se, nesse sentido, sem o apoio da crítica objetiva da própria sociedade. Maar (2003, p. 27) conclui que “Não há sentido para a educação na sociedade burguesa senão o resultante da crítica e da resistência à sociedade vigente responsável pela desumanização”.

O autor ainda adverte que há limitações do esclarecimento desvendadas por Marx e Freud, além da experiência do insucesso da humanização das sociedades, da generalização da alienação pelo capitalismo e da decorrente dissolução da experiência formativa. Mas, considera que "No capitalismo tardio, a preservação das condições objetivas da experiência formativa no contato com o outro e na abertura à história - ao modo de um trabalho social alternativo - é a única possibilidade de evitar a repetição de Auschwitz” (Id. Ibid., p. 28).

Adorno (2003) analisa que a formação deveria desenvolver aptidões críticas, conduzindo as pessoas à capacidade de desmascarar ideologias, ao invés de gerar falsa 
consciência. Mas como ter acesso aos conteúdos curriculares da formação sem ser iludido ou sem se submeter à ideologia?

No retorno ao depoimento dos entrevistados, verifica-se que tiveram contato, vivências - ao contrário de experiências formativas - com conteúdos desconexos sobre autores e teorias de psicologia, por exemplo, a fim de saber o que fazer com o aluno em sala de aula, rompendo-se o nexo entre objeto e reflexão. A formação intelectual que pressupõe ir além do objeto, libertar-se do imediatismo, ultrapassar a aparência, aprofundar-se, distanciou-se. A emancipação também se distancia porque o indivíduo só se emancipa quando se liberta do imediatismo das relações que não são naturais, e sim históricas.

Durante seu processo de formação, os professores são ensinados a detectar nos alunos e em suas famílias as causas da não aprendizagem, ou da não adaptação do aluno às normas escolares. Além disso, consideram que muitos dos problemas políticos seriam resolvidos se profissionais de várias especialidades - psicólogos, assistentes sociais, dentistas, médicos - estivessem na escola controlando as adversidades constantes, como se elas não tivessem vinculação com o contexto educacional. Neste sentido, o que depende das condições objetivas, passa a depender das pessoas. O descaso intencional com a educação pública é compreendido como incapacidade de professores, alunos e pais. Como aponta Adorno (2003, p. 36), “[...] conforme o ditado de que tudo depende unicamente das pessoas, atribuem às pessoas tudo o que depende das condições objetivas, de tal modo que as condições existentes permanecem intocadas”.

A inaptidão à experiência, promovida, dentre outros fatores, por cursos que informam, ao invés de formar, produz uma consciência coisificada na qual há a conversão de uma relação humana em coisa, alterando a experiência. A mutilação da consciência oculta a realidade e propicia violência.

Os cursos de formação têm desempenhado papel importante neste ocultamento da realidade. Possibilitam o encontro com a ilusão no lugar do real, produzindo uma consciência coisificada: “[...] está é sobretudo uma consciência que se defende em relação a qualquer vir-a-ser, frente a qualquer apreensão do próprio condicionamento, impondo como sendo absoluto o que existe de um determinado modo” (Id. Ibid., p. 132). 
A inaptidão, segundo o autor, para realizar experiências intelectuais e conseguir resistir ao processo de coisificação da consciência tem vinculação estreita com a relação que se estabeleceu entre teoria e prática, por meio da divisão social entre trabalho físico e intelectual. O magistério, antes profissão intelectual, passa a ser considerado trabalho físico num sentido bastante desprestigiado e o mestre de escola é visto como um serviçal, sem poder e status. A profissão transmite falta de seriedade e o professor, antes acadêmico, não é considerado socialmente capaz. Encarregou-se de executar o necessário para o funcionamento eficaz da escola e sua função é desprezada. O magistério transforma os docentes em peões: executam tarefas; aplicam técnicas pedagógicas; buscam encaixar teorias psicológicas nos problemas de seus alunos; assumem funções de médicos, secretários de escola, dentistas, psicólogos e deixam de pensar sobre seu papel social como professor, sobre a escola e seus alunos.

Sobreira (1997) afirma que o professor é visto como um sábio que não utiliza o seu conhecimento: não resolve os problemas de aprendizagem dos alunos, é mal remunerado, não dá conta das elevadas taxas de reprovação e evasão, dentre outras dificuldades. A proletarização do magistério apaga o conjunto da história da profissão. O autor assinala que é preciso (re) elaborar a dialética entre profissão e sujeito, entre gênero e sujeito. O primeiro significa a elaboração crítica do passado e o segundo, do cotidiano.

O contato com vivências, ao invés de experiências, é promovido pela divisão social do trabalho, na qual o educador deixou de ser um trabalhador intelectual, como destacado anteriormente. Sobreira (1997) aponta o processo de fetichização da relação teoria-prática na formação do professor, que passa a constituir-se como mera identificação de meios mais apropriados para atingir determinados fins.

A predominância da técnica na formação, segundo o autor, promove o desenvolvimento da consciência coisificada, mutilada. No mundo atual, a técnica ocupa posição decisiva, o que chega a ser patogênico, irracional. Combater a técnica é condição para a não repetição da barbárie. Contudo, isto é o mesmo que combater o espírito atual do mundo; daí a dificuldade de promover uma outra formação:

Os homens inclinam-se a considerar a técnica como sendo algo em si mesma, um fim em si mesmo, uma força própria, esquecendo que ela 
é a extensão do braço dos homens. Os meios - e a técnica é um conceito de meios dirigidos à autoconservação da espécie humana são fetichizados, porque os fins - uma vida humana digna encontram-se encobertos e desconectados da consciência das pessoas (ADORNO, 2003, p. 132-133).

A crença em uma pedagogia científica, fundamentada por uma psicologia também científica, de acordo com Sobreira (1997), deu legitimidade ao discurso da razão instrumental. Crê-se que a prática proporcionará a melhor formação, pois a partir do raciocínio funcional, a melhor maneira de aprender é fazendo. A divergência entre teoria e prática na formação é encontrada em todos os depoimentos. O autor denuncia que a prática sem teoria está destinada ao fracasso:

\begin{abstract}
A formação de professores não pode ser acusada de exageradamente teórica e descontextualizada numa sociedade em que as escolas reais se instalam a partir de uma descontextualização da produção da vida e da cultura. Nesse sentido, poucas coisas seriam tão deformadoras quanto a antecipação da ida do professor para esta escola. Além do mais, se se conceder à prática posição privilegiada como instância formadora do professor pouco faltará para que a determinação de sua competência profissional se desloque de suas credenciais de formação para o monitoramento de suas atividades cotidianas (Id. Ibid., p. 204205).
\end{abstract}

O autor adverte que só se escapa da irracionalidade do ativismo (predomínio da prática sobre a teoria) no interior da própria prática. A teoria - o pensar - deve ser compreendida como forma de atuar e, portanto, é prática. Mas ao mesmo tempo, por ser diferente da prática, a teoria se impõe como força transformadora.

A formação que promove a emancipação, a resistência à barbárie, segundo os autores analisados, pressupõe necessariamente uma formação para experiências e o resgate da relação entre teoria e prática.

Seria, então, possível qualificar o processo de preparação para o magistério, do qual os depoentes fizeram parte, que promove a aversão à teoria e a busca incessante e supervalorizada da prática, como formação? 


\subsection{O abandono da teoria e o processo de pseudoformação ${ }^{56}$}

A semiformação, como destaca Weber (1997), é a onipresença do espírito alienado: a contradição entre formação cultural e sociedade de consumo não tem como resultado a não-cultura, o não-saber, mas sim a semicultura. Refletindo sobre a condição dos trabalhadores - neles incluindo os docentes - verifica-se a negação da formação cultural e em seu lugar é colocada a falsificação da formação, que exclui da consciência dos indivíduos os resquícios de espanto e resistência. O autor afirma que os indivíduos trabalhadores que não detêm os meios de produção já estão, por este motivo, excluídos do processo formativo.

Para Adorno (1996) a pseudoformação é a forma dominante da consciência atual. É produzida, dentre outros fatores, pela separação social entre o trabalho do corpo e o trabalho do espírito. Nas relações mais avançadas do capitalismo, as diferenças econômicas impedem os indivíduos de pensar no sentido e na finalidade da formação cultural. As relações sociais, assim, evitam que a cultura cumpra a promessa de liberdade.

Segundo o autor, a formação deveria se referir ao indivíduo livre e à sua consciência, pressupondo uma sociedade autônoma, uma humanidade sem status e sem exploração. Neste sentido, nas sociedades capitalistas, a formação cultural é convertida em pseudoformação socializada. Todavia, Adorno (1996) afirma que a auto-reflexão crítica sobre a pseudocultura é a única possibilidade de manter viva a cultura em nossos dias, uma vez que, por se desenvolver em uma sociedade contraditória, a cultura tem duplo caráter: de formação e de pseudoformação. Esta fortalece a ideologia e promove uma formação regressiva.

Como realizar a reflexão crítica da pseudoformação, para compreender, por esta via, as possibilidades de formação ainda existentes?

A semiformação - o semi-saber - invade e destrói a possibilidade de realizar experiências formativas como um processo progressivo, emancipador e contínuo. Em

\footnotetext{
${ }^{56}$ Os termos pseudoformação, pseudocultura e seus derivados serão utilizados toda vez que se referir ao trabalho de Adorno (1996), de acordo com a versão espanhola do mesmo texto (2004). Semicultura, semiformação e seus derivados serão mantidos como consta nos textos de outros autores consultados que tratam do mesmo tema.
} 
seu lugar promove vivências: aceleradas, fragmentadas, nas quais a imediaticidade deforma a capacidade de pensar, entender e sentir (PUCCI, 1997).

A semiformação não é um passo para a formação: ao contrário, é seu principal inimigo. Na condição de não-saber, o indivíduo busca saber; mas no semi-saber, a pessoa julga-se sabedora. A semiformação, assim, é o semi-entendido, o semiexperimentado, que possui status de entendido e experimentado: "Na verdade a semiformação, ao invés de instigar as pessoas a desenvolverem plenamente suas potencialidades e assim colaborarem efetivamente na transformação social, propicia um verniz formativo que não dá condições de se ir além da superfície” (Id. Ibid., p. 97).

Adorno (1996) afirma que o pseudoculto não pode permitir a experiência e o conceito - a teoria. Esta é substituída por clichês já prontos. A pseudoformação, dessa forma, é uma fraqueza em relação ao tempo, à memória, à mediação:

[...] A experiência - a continuidade da consciência em que perdura o ainda não existente e em que o exercício e a associação fundamentam uma tradição no indivíduo - fica substituída por um estado informativo pontual, desconectado, intercambiável e efêmero, e que se sabe que ficará borrado no próximo instante por outras informações (Id. Ibid., p. 405).

Para o autor, na pseudoformação os conteúdos coisificados, com caráter de mercadoria, se sobrepõem ao conteúdo de verdade dos bens culturais. O oferecimento destes às massas, como forma de expansão da cultura, por meio da indústria cultural, nega-lhes o processo real da formação porque não lhes dá condições de apropriação dos bens. Por isso, o espírito da indústria cultural é a pseudocultura, a identificação, a duplicação mais perfeita da realidade, que inviabiliza o pensamento, pois não deixa brechas para a reflexão do indivíduo.

Adorno (1996) aponta que essa expansão da formação cultural às massas, o que torna os bens culturais produtos de entretenimento baratos e vazios, é a sua própria aniquilação. Popularizar a formação, ampliando o acesso aos bens culturais gera pseudoformação, mas também é condição de formação. Assim, a formação continua sendo a única possibilidade de superar a pseudoformação: 
[...] A formação tem como condições a autonomia e a liberdade. No entanto, remete sempre a estruturas pré-colocadas a cada indivíduo em sentido heteronômico e em relação às quais deve submeter-se para formar-se. Daí que, no momento em que ocorre a formação, ela já deixa de existir. Em sua origem já está, teleologicamente, seu decair (Id. Ibid., p. 397).

A racionalidade burguesa, dessa forma, traz a devastação do espírito e impossibilita a formação. A não-cultura ainda tinha a capacidade de elevar os indivíduos à consciência crítica, mas isto está fora do alcance da pseudoformação cultural. A contradição entre formação cultural e a sociedade organizada em classes sociais não produz a não-culura, a incultura, mas a pseudocultura.

Nos depoimentos, os entrevistados avaliam que ora são bem formados em alguns aspectos, ora não possuem formação. Sandra, como exemplo, afirma que o magistério não lhe ensinou a ser professora. Porém, ela atua como docente, instrumentalizada por um processo de pseudoformação. No lugar da não-preparação para o magistério há a pseudopreparação impregnada de valores, crenças, concepções, preconceitos, maneiras de agir, visões de desenvolvimento e de aprendizagem, de disciplina, de contexto educacional.

O retorno ou resgate da teoria é, assim, condição inerente de combate à pseudoformação e a possibilidade de conduzir à experiência e à emancipação. Ao analisar o depoimento dos entrevistados, nota-se que a pseudoformação, que constituiu sua vida profissional, fortaleceu-se com a divisão e até mesmo com a oposição entre teoria e prática. Tal fortalecimento aumenta o desejo por vivências práticas e consolida a idéia de que os problemas da escola - vistos mais precisamente como dos alunos - serão solucionados com reformas pedagógicas. A semiformação, para Pucci (1997), travou a dimensão emancipatória da cultura em favor da dimensão instrumental da razão.

Como enfatizado por Adorno (1996), a única possibilidade de sobrevivência da cultura - e, portanto, da formação - é o exercício da auto-reflexão crítica sobre a pseudoformação. Daí a importância de se resgatar, no processo educacional, a experiência formativa. Este resgate significa a crítica radical aos momentos/situações que impeçam o homem de viver plenamente sua capacidade de realizar experiências. É, além disso, a luta para "mudar radicalmente as condições sociais e materiais de 
produção que continuamente geram as múltiplas situações de vivência que abafam as possibilidades de experiências” (PUCCI, 1997, p. 112).

Ir contra a semiformação, neste sentido, é, segundo o autor, educar para a contradição e para a resistência. A emancipação - autonomia, maioridade - não ocorre simplesmente por processos de escolarização; por isso, a formação do professor não se dá apenas nos cursos de formação, mas também por meio da cultura, da arte, da política, da ética. A educação, compreendida de maneira ampla, é a possibilidade de resistir criticamente ao processo de semiformação e à própria sociedade burguesa que gerou esse processo.

Weber (1997) destaca que duas dimensões fazem parte da racionalidade burguesa: a emancipatória e a instrumental, mas houve a dominação da dimensão instrumental na cultura e o conseqüente desvirtuamento da emancipatória. Maar (2003, p. 19) complementa: “A crise do processo formativo e educacional, portanto, é uma conclusão inevitável da dinâmica atual do processo produtivo. A dissolução da formação como experiência formativa redunda no império do que se encontra formado, na dominação do existente”.

A conseqüência, então, do processo produtivo é a apresentação da pseudoformação como formação. Como enfrentar a dominação da dimensão instrumental, atingindo a emancipatória?

Para Sobreira (1997), a elaboração de dois tabus são a base do processo formativo de sujeitos emancipados: a relação teoria-prática e a proletarização do magistério. Estes são responsáveis pela mutilação da formação do professor:

[...] a superação da deformação profissional precisa dos momentos de elaboração interna, seguramente idiossincráticos, da forma como os conteúdos concretos dos tabus foram assimilados pelos professores em formação. O processo acrítico de semiformação contenta-se com a apresentação de uma lista (cada vez mais longa) de esclarecimentos externos sobre os aspectos sociológicos, filosóficos, econômicos etc. do ser professor (Id. Ibid., p. 212, grifo do autor).

O autor considera, ainda, que o processo de formação do professor deve se constituir como auto-reflexão sobre o passado do indivíduo e também da profissão docente. Uma das questões apontadas por Adorno (2003) para enfrentar o processo de 
pseudoformação diz respeito à necessidade de elaboração do passado. Esta é a possibilidade de esclarecimento, de inflexão em direção ao sujeito. Elaborar o passado significa adquirir consciência da pseudoformação; o esclarecimento racional não dissolve diretamente os mecanismos que promovem a pseudoformação, mas fortalecem os mecanismos de resistência. A conscientização é, nesta perspectiva, a constituição da aptidão à experiência. A consciência, para o autor, não é apenas a capacidade formal de pensar:

[...] aquilo que caracteriza propriamente a consciência é o pensar em relação à realidade, ao conteúdo - a relação entre as formas e estruturas de pensamento do sujeito e aquilo que este não é. Este sentido mais profundo de consciência ou faculdade de pensar não é apenas o desenvolvimento lógico formal, mas ele corresponde literalmente à capacidade de fazer experiências. Eu diria que pensar é o mesmo que fazer experiências intelectuais. Nesta medida, e nos termos que procuramos expor, a educação para a experiência é idêntica à educação para a emancipação (Id. Ibid., p. 151).

Adorno (2003) enfatiza a necessidade de fortalecer nas Universidades e nos cursos de preparação para o magistério uma sociologia vinculada à pesquisa histórica de nossa própria época. Destaca, também a importância da presença da filosofia na formação de professores. Ao discutir as decisões a respeito da educação, ressalta que modelos autoritários, impostos a partir do exterior contradizem a idéia de homem autônomo, emancipado e, neste sentido, as mudanças curriculares ou os modismos pedagógicos implementados nas escolas, sem qualquer consulta aos docentes constituem-se como momentos repressivos que produzem a pseudoformação.

A educação para a emancipação, como forma de contestação e resistência, é eliminada já na formação dos formadores. “A crise da formação é a expressão mais desenvolvida da crise da sociedade moderna” (MAAR, 2003, p. 16). Por isso, a pseudoformação, para o autor, é a base social de uma estrutura de dominação.

Contra a crise gerada pela pseudoformação, de acordo com Adorno (1996), é preciso resgatar uma teoria que seja abrangente. No caso da escola, reformas pedagógicas isoladas não trazem contribuições substanciais à crise da formação cultural; em certas ocasiões chegam a reforçar a crise “[...] porque abrandam as necessárias exigências a serem feitas aos que devem ser educados e porque revelam uma inocente 
despreocupação diante do poder que a realidade extrapedagógica exerce sobre eles” (Id. Ibid, p. 388). As reformas escolares enfraquecem a dedicação e o aprofundamento espiritual vinculados à liberdade. Do mesmo modo, reflexões e investigações isoladas e movimento sociais parciais não resolvem o problema da pseudoformação.

A impossibilidade da formação, segundo Adorno (2003), faz parte de um contexto de descompasso entre a cultura e a civilização material, no qual os homens já produziram as condições materiais, tecnológicas e científicas para suprimir o sofrimento no que se refere à fome, à saúde, às condições de habitação, de educação, dentre outros âmbitos que compõem a vida humana. Porém, há uma crise do trabalho formador, a deformação da subjetividade pela forma concreta do trabalho social.

Assim, a pseudoformação vincula-se às condições objetivas do desenvolvimento social e deve, também, ser analisada neste âmbito. A pseudoformação cultural é a alienação onipresente, a socialização do espírito conquistado pelo caráter de fetiche da mercadoria:

[...] A vida, modelada até suas últimas ramificações pelo princípio da equivalência, esgota-se na reprodução de si mesma, na reiteração do sistema, e suas exigências descarregam-se sobre os indivíduos tão dura e despoticamente, que cada um deles não pode se manter firme contra elas como condutor de sua própria vida, nem incorporá-las como algo específico da condição humana. Daí que a existência desconsolada, a alma, que não atingiu seu direito divino na vida tenha necessidade de substituir as perdidas imagens e formas através da semiformação (ADORNO, 1996, p. 399).

Apesar das condições objetivas totalitárias que socializam a pseudoformação, o autor afirma que a formação cultural tradicional, mesmo que questionável, é a única que serve de antítese à pseudoformação. Destaca a importância da teoria, nesse sentido, porque ela não se reduz à abreviatura dos fatos e preserva as possibilidades de mediação.

Como resgatar processos formativos orientados para a busca de experiência, para o retorno à teoria como práxis? Como formar professores para a autonomia, para a autoreflexão, enfim, para o desenvolvimento do espírito, do pensamento, contra a barbárie, para que possam ser formadores? 
Como a psicologia pode se inserir na formação de professores, promovendo a consciência crítica, ao invés de oferecer receitas para aperfeiçoar o ensino, conforme mostram os depoimentos dos entrevistados?

\subsection{Da psicologia dos depoimentos a uma outra psicologia: a desconstrução}

Essas indagações estiveram presentes em toda a trajetória de desenvolvimento desse trabalho. Desde o início, estava posta a pergunta "o que a psicologia tem a oferecer à formação de professores?”. Para respondê-la, me deparei com outra ainda mais inquietante: “qual a psicologia que pode trazer esta contribuição?”.

Ao longo das entrevistas, indaguei incessantemente os depoentes - como expressão de minha própria angústia - sobre as contribuições da psicologia em sua formação e em seu trabalho pedagógico e como eles acreditavam que ela deveria se inserir no contexto escolar. Mesmo obtendo a resposta possível dos depoentes, eu continuava perguntando.

Aos poucos percebi que eles já haviam dado a sua resposta, sempre relacionada à sua história de formação pedagógica, mas eu não tinha encontrado a minha resposta. Os depoimentos serviam para que a inquietação aumentasse: se a psicologia apresentada aos depoentes é, essencialmente, fragmento de autor e teoria sobre desenvolvimento e aprendizagem que os orienta para a procura de técnicas de ensino - ou seja, a psicologia que lhes é ensinada é parte da pseudoformação - como oferecer uma formação em psicologia que quebre o que se cristalizou?

Quando iniciei o mestrado, acreditava que o problema da formação em psicologia dizia respeito à mudança de metodologia de ensino, isto é, à busca de teorias de desenvolvimento e de aprendizagem que contribuíssem de modo mais eficaz com a formação de professores. Assim, bastaria encontrar a teoria de psicologia que tivesse princípios emancipatórios, que combatesse as relações de opressão na escola e que pudesse aperfeiçoar o ensino - uma teoria que aumentasse a eficácia técnica do professor. 
Não é preciso dizer que, durante os depoimentos, encontrei respostas que, ao mesmo tempo em que corroboravam minha idéia inicial, chocavam-se totalmente com o princípio da eficácia técnica.

Então, compreendi o papel da unidade dialética entre teoria e prática na formação do professor e na minha também. Mas é especialmente o retorno à teoria, tão abandonada no mundo tecnicamente orientado, que pode permitir encontrar as brechas necessárias para romper com os processos de pseudoformação. Aqui se encontra a oportunidade de se entender o presente e sinalizar outras possibilidades para o futuro.

A psicologia certamente não pode salvar a escola. Mas criticar a psicologia como forma de aperfeiçoamento das relações pedagógicas ou ainda como explicação naturalizante para os problemas de escolarização pode desvelar os danos que ela tem causado para a instituição escolar e para a formação de professores.

Qual o espaço da psicologia na escola, então? Talvez, em Kupfer (2000, p. 136) possa estar uma primeira resposta:

Os discursos institucionais tendem a produzir repetições, mesmice, na tentativa de preservar o igual e garantir sua permanência. Contra isso, emergem vez por outra falas de sujeitos, que buscam operar rachaduras no que está cristalizado. É exatamente como "auxiliar de produção" de tais emergências que um profissional orientado pela psicanálise pode encontrar seu lugar em uma instituição escolar.

A primeira rachadura foi operada em mim mesma. O objetivo do profissional da psicologia seria, nesse sentido, abrir espaço na escola para a circulação de discursos e ficar em posição de escuta ativa.

Na formação, como aponta Kupfer (2000), não se trata de ensinar psicanálise aos professores ou psicanalisá-los, ou ensinar técnicas psicológicas com a finalidade de aperfeiçoamento das relações entre ensino e aprendizagem. O retorno à teoria pode ser útil ao educador por levar em conta o sujeito: "Precisamos, então, de uma teoria que seja capaz de refletir e criar instrumentos para operar com um sujeito em sua articulação com o campo social escolar. Precisamos de uma teoria que supere a dicotomia indivíduosociedade” (Id. Ibid., p. 128). 
A psicologia como parte de um processo de formação é a desconstrução da psicologia. Esta pode ser a possibilidade de retornar à teoria, de promover experiências intelectuais, de romper com o pragmatismo que limita o pensamento.

É preciso mostrar àqueles que pretendem exercer o ofício do magistério - ao contrário do que lhes ensinam os cursos de formação - que é possível sim ensinar a classes heterogêneas de quarenta alunos, respeitando a heterogeneidade como atitude política. As crianças são diferentes umas das outras e, mesmo assim, é possível ensinálas! Além disso, torna-se necessário ter consciência de que os indivíduos não são totalmente controláveis e que, portanto, é ilusão querer ter o controle absoluto dos processos psíquicos dos alunos.

Nesta desconstrução é tarefa fundamental historicizar, como fez Bisseret (1979), o conhecimento produzido pela psicologia em sua relação com a educação, quando se quer uma psicologia participante de um processo formativo.

O projeto filosófico da formação diz respeito àquele apontado por Maia (2002): considerar radicalmente a condição social e recuperar historicamente o processo dialético do esclarecimento, que se dá por meio da teoria:

De uma práxis que se opunha à ideologia, a crítica atualmente se refugia na teoria, procurando fugir a meros termos operacionais ou estatísticas que vigiam o funcionamento ótimo da máquina administrativa, mas neste refúgio, ao contrário de furtar-se à práxis, a crítica não deixa de ser também prática e política (Id. Ibid., p. 64-65).

O autor conclui que a formação bem-sucedida não é a que reconcilia as contradições, mas a que exprime negativamente a idéia de harmonia. É isto que falta à psicologia: explicitar contradições ao invés de ocultá-las.

No início desse trabalho, não percebi que estava ocultando as contradições vivenciadas pela psicologia na formação de educadores. Por um instante quase desisti: a psicologia ensinada aos docentes não contribui para sua formação; ao contrário, produz pseudoformação. A psicologia, dessa forma, não daria conta de transformar as relações escolares de ensino e de aprendizagem. Quase concluí que ela deveria ser eliminada dos currículos de licenciatura, magistério e Pedagogia, já que realizava um desserviço. 
Posteriormente compreendi que há um longo caminho a percorrer e que a psicologia necessita continuar na formação, em primeiro lugar e de forma urgente, como desconstrução. Esta pode ser a forma de torná-la parte do combate ao processo da pseudoformação, rumo à construção de uma outra psicologia que contribua para a formação docente.

Assim, não é qualquer psicologia que pode garantir processos de formação, mas sim aquela que coloque em questão as crenças sobre ensino e aprendizagem eficazes e, dessa forma, garanta uma outra inserção dos professores no ensino de seus alunos. Esta psicologia teria a chance de pôr os professores a pensar seu próprio pensamento.

A inserção da psicologia na formação e do psicólogo nas escolas precisa abandonar sua forma prescritiva. Assim, poderá produzir o desvelamento das relações de poder, alterando seu foco da criança e seu desenvolvimento para a escola como instituição.

Para garantir uma outra presença da psicologia na formação de professores é preciso refletir também sobre a formação dos próprios psicólogos. A nova tarefa, então, passa a ser o encontro com a psicologia que contribua para pensar a formação de psicólogos e, neste sentido, a de professores. 


\section{REFERÊNCIAS BIBLIOGRÁFICAS}

ADORNO, Theodor W. Notas marginais sobre teoria e práxis. In: Palavras e sinais: modelos críticos 2. Tradução Maria Helena Ruschel. Petrópolis, RJ: Vozes, 1995. p. 202-231. $\overline{\text { dez. } 1996 .}$

. Teoria da semicultura. Educação e Sociedade, ano XVII, n. 56, p. 388-411, . Educação e emancipação. 3. ed. Rio de Janeiro: Paz e Terra, 2003.

Teoría de la pseudocultura. In: Escritos sociológicos I - Obra completa, 8. Tradução Agustín Gonzáles Ruiz. España: Ediciones Akal, 2004. p. 86-113.

ALMEIDA, Patrícia Cristina Albieri de. Discutindo a relação professor-licenciado e aluno-adolescente à luz da formação em psicologia. In: AZZI, Roberta Gurgel; BATISTA, Sylvia Helena Souza da Silva; SADALLA, Ana Maria Falcão de Aragão (Orgs.). Formação de Professores: discutindo o ensino de Psicologia. Campinas, SP: Alínea, 2000. p. 97-118.

ANDALÓ, Carmen Silva de Arruda. Fala Professora! Repensando o aperfeiçoamento docente. Petrópolis, RJ: Vozes, 1995.

ANFOPE. Políticas Públicas de Formação dos Profissionais da Educação: Desafios para as Instituições de Ensino Superior. Documento Final do XII Encontro Nacional da Anfope. 2004. Disponível em: <http:lite.fae.unicamp.br/anfope>. Acesso em fev. 2005

ASSOCIAÇÃO BRASILEIRA DE NORMAS TÉCNICAS. Informação e documentação - Referências - Elaboração. NBR 6023. Rio de Janeiro, ago. 2002.

Informação e documentação - Citações em documentos - Apresentação.

NBR 10520. Rio de Janeiro, ago. 2002. 
AZANHA, José Mário Pires. O ensino superior e sua articulação com os ensino fundamental e médio. In: . Educação: temas polêmicos. São Paulo: Martins

Fontes, 1995a. p. 49-54.

. Uma proposta para a licenciatura na USP. In: Educação: temas

polêmicos. São Paulo: Martins Fontes, 1995b. p. 55-65.

Comentários sobre a formação de professores em São Paulo. In:

Educação: temas polêmicos. São Paulo: Martins Fontes, 1995c. p. 191-204.

Proposta pedagógica e autonomia da escola. Cadernos de História e Filosofia da Educação, São Paulo, v. II, n. 4, p. 11-21, 1998.

. Uma reflexão sobre a formação do professor da escola básica. In: Conselho Estadual de Educação, Processo CEE N. ${ }^{\circ}$ 64-99, São Paulo, jun. 2000, p. 4-21.

AZZI, Roberta Gurgel; BATISTA, Sylvia Helena Souza da Silva; SADALLA, Ana Maria Falcão de Aragão (Orgs.). Formação de Professores: discutindo o ensino de Psicologia. Campinas, SP: Alínea, 2000.

AZZI, Roberta Gurgel; PEREIRA, Marli Amélia Lucas; BATISTA, Sylvia Helena Souza da Silva. Ensino de psicologia na licenciatura: estratégias de ensino como facilitadoras da articulação entre realidade da escola e conteúdo teórico. In: AZZI, Roberta Gurgel; BATISTA, Sylvia Helena Souza da Silva; SADALLA, Ana Maria Falcão de Aragão (Orgs.). Formação de Professores: discutindo o ensino de Psicologia. Campinas, SP: Alínea, 2000. p. 163-180.

BATISTA, Sylvia Helena Souza da Silva; AZZI, Roberta Gurgel. Ensinando psicologia na licenciatura: experiências, opções e aprendizagens. In: AZZI, Roberta Gurgel; BATISTA, Sylvia Helena Souza da Silva; SADALLA, Ana Maria Falcão de Aragão (Orgs.). Formação de Professores: discutindo o ensino de Psicologia. Campinas, SP: Alínea, 2000. p. 149-161.

BISSERET, Noëlle. A ideologia das aptidões naturais. In: DURAND, J. C. G. (Org.). Educação e hegemonia de classe. Rio de Janeiro: Jorge Zahar, 1979. p. 30-67.

BOSI, Alfredo. Educação: as pessoas e as coisas. Comunicação \& Educação, São Paulo, n. 7, p. 13-15, set./dez. 1996. 
BOURDIEU, Pierre. Contrafogos: táticas para enfrentar a invasão neoliberal. Tradução Lucy Magalhães. Rio de Janeiro: Jorge Zahar, 1998.

. Contrafogos 2: por um movimento social europeu. Tradução André Telles.

Rio de Janeiro: Jorge Zahar, 2001.

CAMPOS, Roselane Fátima. O Cenário da Formação de Professores no Brasil Analisando os Impactos da Reforma da Formação de Professores (versão preliminar). 2004. Disponível em: <http:lite.fae.unicamp.br/anfope>. Acesso em fev. 2005.

CAPARROZ, Aceli de Assis Magalhães. A Psicologia da Educação e os cursos de licenciatura nas faculdades particulares do município de São Paulo. Dissertação (Mestrado em Psicologia da Educação) - Pontifícia Universidade Católica de São Paulo, São Paulo, 1992.

CARVALHO, José Sérgio Fonseca de. Construtivismo: uma pedagogia esquecida da escola. Porto Alegre: Artmed, 2001.

CONNELL, R. W. Pobreza e educação. In: GENTILI, Pablo (Org.). Pedagogia da exclusão: crítica ao neoliberalismo em educação. 11. ed. Tradução Vânia Paganini Thurler e Tomaz Tadeu da Silva. Petrópolis, RJ: Vozes, 2004. p. 11-42.

COSTA, Márcio da. A educação em tempos de conservadorismo. In: GENTILI, Pablo (Org.). Pedagogia da exclusão: crítica ao neoliberalismo em educação. 11. ed. Tradução Vânia Paganini Thurler e Tomaz Tadeu da Silva. Petrópolis, RJ: Vozes, 2004. p. 43-76.

CROCHIK, José Leon. A personalidade narcisista segundo a Escola de Frankfurt e a ideologia da racionalidade tecnológica. Psicologia USP, São Paulo, v. 1, n. 2, p. 141154, 1990.

Apontamentos sobre o texto "Educação após Auschwitz” de T. W. Adorno. Educação e Sociedade, n. 42, p. 342-351, ago. 1992.

FONSECA, Marília. O Banco Mundial e a educação: reflexões sobre o caso brasileiro. In: GENTILI, Pablo (Org.). Pedagogia da exclusão: crítica ao neoliberalismo em 
educação. 11. ed. Tradução Vânia Paganini Thurler e Tomaz Tadeu da Silva. Petrópolis, RJ: Vozes, 2004. p. 169-195.

FRIGOTTO, Gaudêncio. Os delírios da razão: crise do capital e metamorfose conceitual no campo educacional. In: GENTILI, Pablo (Org.). Pedagogia da exclusão: crítica ao neoliberalismo em educação. 11. ed. Tradução Vânia Paganini Thurler e Tomaz Tadeu da Silva. Petrópolis, RJ: Vozes, 2004. p. 77-108.

GATTI, Bernardete A. Formação continuada de professores: a questão psicossocial. Cadernos de Pesquisa, n. 119, p. 191-204, jul. 2003.

GENTILI, Pablo. A falsificação do consenso: simulacro e imposição na reforma educacional do neoliberalismo. 3. ed. Petrópolis, RJ: Vozes, 2002.

Adeus à escola pública: a desordem neoliberal, a violência do mercado e o destino da educação das maiorias. In: GENTILI, Pablo (Org.). Pedagogia da exclusão: crítica ao neoliberalismo em educação. 11. ed. Tradução Vânia Paganini Thurler e Tomaz Tadeu da Silva. Petrópolis, RJ: Vozes, 2004. p. 228-252.

. (Org.). Pedagogia da exclusão: crítica ao neoliberalismo em educação. 11. ed. Tradução Vânia Paganini Thurler e Tomaz Tadeu da Silva. Petrópolis, RJ: Vozes, 2004.

GINZBURG, Carlo. O queijo e os vermes - o cotidiano e as idéias de um moleiro perseguido pela inquisição. Tradução Maria Betânia Amoroso. 8. reimpr. São Paulo: Companhia das Letras, 1987.

GUERRA, Clarisa Terezinha. Conhecimento psicológico e formação de professores. In: AZZI, Roberta Gurgel; BATISTA, Sylvia Helena Souza da Silva; SADALLA, Ana Maria Falcão de Aragão (Orgs.). Formação de Professores: discutindo o ensino de Psicologia. Campinas, SP: Alínea, 2000. p. 69-96.

KUPFER, Maria Cristina Machado. Uma educação para o sujeito. In: . Educação

para o futuro: psicanálise e educação. São Paulo: Escuta, 2000. p. 117-148.

LAROCCA, Priscila. O ensino de psicologia da educação sob o olhar de licenciados e licenciandos. In: AZZI, Roberta Gurgel; BATISTA, Sylvia Helena Souza da Silva; 
SADALLA, Ana Maria Falcão de Aragão (Orgs.). Formação de Professores: discutindo o ensino de Psicologia. Campinas, SP: Alínea, 2000. p. 119-145.

LEITE, Sérgio Antonio da Silva. Desenvolvimento profissional do professor. In: AZZI, Roberta Gurgel; BATISTA, Sylvia Helena Souza da Silva; SADALLA, Ana Maria Falcão de Aragão (Orgs.). Formação de Professores: discutindo o ensino de Psicologia. Campinas, SP: Alínea, 2000. p. 39-66.

LEOPOLDO E SILVA, Franklin. Conhecimento e razão instrumental. Psicologia USP, São Paulo, v. 8, n.1, p. 11-31, 1997.

LOURENÇO FILHO, M. B. Introdução ao Estudo da Escola Nova: bases, sistemas e diretrizes da pedagogia contemporânea. 12. ed. São Paulo: Melhoramentos, 1978.

MAAR, Wolfgang Leo. À guisa de introdução: Adorno e a experiência formativa. In: ADORNO, Theodor W. Educação e emancipação. 3. ed. Rio de Janeiro: Paz e Terra, 2003. p. 11-28.

MAIA, Ari Fernando. Televisão e barbárie: um estudo sobre a indústria cultural brasileira. 226f. Tese (Doutorado em Psicologia Escolar e do Desenvolvimento Humano) - Instituto de Psicologia, Universidade de São Paulo, São Paulo, 2002.

PATTO, Maria Helena Souza. Formação de professores: o lugar das humanidades. In: BARBOSA, R. L. L. (Org.). Trajetórias e perspectivas da formação de educadores. São Paulo: UNESP, 2004. p. 61-78.

PUCCI, Bruno. A teoria da semicultura e suas contribuições para a teoria crítica da educação. In: ZUIN, Antônio Álvaro Soares; PUCCI, Bruno; OLIVEIRA, Newton Ramos de (Orgs.). A Educação danificada: contribuições à teoria crítica da educação. Petrópolis, RJ: Vozes, São Carlos, SP: Universidade Federal de São Carlos, 1997. p. 89115.

RODRIGUES, Arakcy Martins. Operário, Operária - estudo exploratório sobre o operariado industrial da Grande São Paulo. 2. ed. São Paulo: Símbolo, 1978. 
SADALLA, Ana Maria Falcão de Aragão; WISNIVESKY, Mariana; PAULUCCI, Fernanda Costa; VIEIRA, Carolina Pasquote. Teorias implícitas na ação docente: contribuição teórica ao desenvolvimento do professor prático-reflexivo. In: AZZI, Roberta Gurgel; BATISTA, Sylvia Helena Souza da Silva; SADALLA, Ana Maria Falcão de Aragão (Orgs.). Formação de Professores: discutindo o ensino de Psicologia. Campinas, SP: Alínea, 2000. p. 21-38.

SOBREIRA, Henrique Garcia. Perspectivas na formação do professor. In: ZUIN, Antônio Álvaro Soares; PUCCI, Bruno; OLIVEIRA, Newton Ramos de (Orgs.). A Educação danificada: contribuições à teoria crítica da educação. Petrópolis, RJ: Vozes, São Carlos, SP: Universidade Federal de São Carlos, 1997. p. 195-216.

SUÁREZ, Daniel. O princípio educativo da nova direita: neoliberalismo, ética e escola pública. In: GENTILI, Pablo (Org.). Pedagogia da exclusão: crítica ao neoliberalismo em educação. 11. ed. Tradução Vânia Paganini Thurler e Tomaz Tadeu da Silva. Petrópolis, RJ: Vozes, 2004. p. 253-270.

THIOLLENT, Michel. O Processo de Entrevista. In: Crítica Metodológica,

Investigação Social e Enquête Operária. São Paulo: Polis, 1981. p. 79-99.

TORRES, Carlos Alberto. Estado, privatização e política educacional: elementos para uma crítica do neoliberalismo. In: GENTILI, Pablo (Org.). Pedagogia da exclusão: crítica ao neoliberalismo em educação. 11. ed. Tradução Vânia Paganini Thurler e Tomaz Tadeu da Silva. Petrópolis, RJ: Vozes, 2004. p. 109-136.

WEBER, Wagner Luís. O mosquito na vidraça: a formação dos cidadãos à luz da teoria crítica da Escola de Frankfurt. In: ZUIN, Antônio Álvaro Soares; PUCCI, Bruno; OLIVEIRA, Newton Ramos de (Orgs.). A Educação danificada: contribuições à teoria crítica da educação. Petrópolis, RJ: Vozes, São Carlos, SP: Universidade Federal de São Carlos, 1997. p. 139-158. 